UNIVERSIDADE DE SÃO PAULO

FACULDADE DE EDUCAÇÃO, INSTITUTO DE BIOCIÊNCIAS, INSTITUTO DE FÍSICA E INSTITUTO DE QUÍMICA

PROGRAMA DE PÓS-GRADUAÇÃO INTERUNIDADES EM ENSINO DE CIÊNCIAS

MAYUMI YAMADA

\title{
A MEDIAÇÃO DOCENTE NA PRODUÇÃO DE TEXTOS ESCRITOS EM AULAS DE ECOLOGIA
}




\section{A MEDIAÇÃO DOCENTE NA PRODUÇÃO DE TEXTOS ESCRITOS EM AULAS DE ECOLOGIA}

Dissertação apresentada à Faculdade de Educação, Instituto de Biociências, Instituto de Física e Instituto de Química da Universidade de São Paulo para a obtenção do título de Mestre em Ensino de Ciências.

Área de concentração: Ensino de Biologia

Orientador: Prof. Dr. Marcelo Tadeu Motokane 
Autorizo a reprodução e divulgação total ou parcial deste trabalho, por qualquer meio convencional ou eletrônico, para fins de estudo e pesquisa, desde que citada a fonte.

\section{FICHA CATALOGRÁFICA}

Preparada pelo Serviço de Biblioteca e Informação do Instituto de Física da Universidade de São Paulo

\section{Yamada, Mayumi}

A mediação docente na produção de textos escritos em aulas de Ecologia. São Paulo, 2013.

Dissertação (Mestrado) - Universidade de São Paulo.

Faculdade de Educação, Instituto de Física, Instituto de Química e Instituto de Biociências

Orientador: Prof. Dr. Marcelo Tadeu Motokane

Área de Concentração: Ensino de Biologia

Unitermos: 1. Biologia, 2. Ensino; 3. Ecologia;

4. Ensino Fundamental. 


\section{AGRADECIMENTOS}

Meus sinceros agradecimentos ao Prof. Dr. Marcelo Tadeu Motokane pelas inúmeras oportunidades que me ofereceu desde a minha aproximação com o grupo Lince. Não foram apenas oportunidades acadêmicas, mas também oportunidades de amadurecimento pessoal (de acreditar no meu próprio potencial; de reconhecer e aceitar minhas limitações; de reconhecer, aceitar os erros e seguir em frente). Enfim, agradeço a oportunidade que me ofereceu de compartilhar e celebrar a vida.

À Universidade de São Paulo e à Coordenação de Aperfeiçoamento de Pessoal de Nível Superior pelo financiamento da minha pesquisa.

À Prof. Dra Silvia Luzia Frateschi Trivelato e ao Prof. Dr. Renilson Menegassi pelas contribuições no exame de qualificação.

Agradeço ao Matheus por estar sempre ao meu lado, pelo apoio e compreensão em todos os momentos difíceis que passamos, por ser sempre sincero, honesto e fiel. Por ser meu amigo, meu companheiro, meu marido, meu amor verdadeiro.

Ao grupo de Pesquisa em Linguagem e Ensino de Ciências (LINCE), em especial à Luziene e Renato pela amizade e pela companhia sempre divertida nos cursos de formação. À Mariana, Maria Carolina, Michele, Teresa, Fabiana, Danilo, Bianca, Ana, e à Lina pelas inúmeras contribuições.

Aos meus queridos amigos Caio e Marcelo, companheiros de todas as horas e apertos, por tornar a vida mais alegre e cheia de sonhos.

À Claire, Márcia, Camila, Carol, Juliana, Albrechet, Amanda, Nathy, Bia, Kathy e Ana por todos os nossos momentos. À Marinalva, Saulo, Marcelo e Tiago, meus irmãos de coração.

À família Tokairin e à Sirlei que me acolheram sempre com muito carinho me fazendo sentir, desde o início, como parte da família.

Aos meus pais, que por mais difícil que seja entender o que faço até hoje, sempre estiveram do meu lado, confiando e me apoiando. E à minha irmã Erika, meu cunhado Hercules, Elise e Michael por fortalecer a fé que existe em mim. 


\section{RESUMO}

YAMADA, M. A mediação docente na produção de textos escritos em aulas de Ecologia. 2013. 136 f. Dissertação (mestrado) - Faculdade de Educação, Instituto de Biociências, Instituto de Física e Instituto de Química da Universidade de São Paulo.

O ponto de partida deste trabalho é a perspectiva do ensino de ciências que tem como foco o desenvolvimento de indivíduos como membros conscientes e críticos na sociedade. Diante da ascensão da cultura científica e tecnológica, é importante que a educação científica promova condições para que os alunos participem ativamente dessas questões, sendo dessa forma alfabetizados cientificamente.

Nesse sentido, a linguagem torna-se imprescindível, uma vez que é o elemento essencial de interação e comunicação; é intrínseca nas culturas da sociedade, inclusive na cultura científica, constituindo-se como meio de produção do conhecimento e também de construção de uma identidade social.

Partindo desse referencial, compreendemos que a produção textual pode ser resultado de várias interações ocorridas não apenas em sala de aula, mas sim diante de um quadro enunciativo mais abrangente. Sendo assim, sob a perspectiva de Bakhtin e seu círculo, nos propomos a investigar essas interações (estabelecidas durante a preparação e a aplicação da sequência didática) e suas relações com a mediação da professora e a produção textual dos alunos a partir de uma sequência didática. Para isso, buscamos caracterizar os comportamentos responsivos dos sujeitos envolvidos a partir das transcrições das falas e dos textos escritos dos alunos. Por comportamento responsivo entendemos que em um movimento dialógico, a intenção ou atitude de um sujeito é compreendida pelo seu interlocutor e a partir dessa compreensão adotará atitudes em resposta ao primeiro, e vice-versa. Essas atitudes, por sua vez, esboçam determinados comportamentos responsivos que conduzem basicamente à reprodução de conhecimentos (passivo) ou à reinterpretação de conhecimentos (ativo).

De acordo com os resultados, vimos que a mediação da professora pode ser influenciada por comportamentos responsivos que não estão exclusivamente na aula dada. No caso desta pesquisa, a interação com o mediador e o contato prévio que a professora teve com o material da sequência didática influenciou sua postura em sala de aula. Além disso, foi possível observar que o aluno em seu processo de construção de conhecimento durante a elaboração de um texto escrito apresenta fases em que se apropria de discursos alheios e fases em que a internalização desses discursos já se tornaram um discurso próprio. Nesse aspecto, concluímos que no processo de alfabetização científica, é importante que o discurso do professor e o material utilizado em sala de aula estejam conectados, uma vez que os alunos podem reproduzir tanto o que é considerado cientificamente aceito, mas também termos e ideias equivocadas. Além disso, um material que não dá possibilidades de criação por parte do professor pode restringir suas atitudes e dos alunos em comportamentos passivos.

Palavras-chave: Alfabetização científica, Linguagem, Ensino de Biologia, Ecologia. 


\begin{abstract}
YAMADA, M. Scaffolding students' writing in Ecology class. 2013. Dissertation (Master in Science Education - Biology Education) University of São Paulo, São Paulo.
\end{abstract}

The starting point of this work is the perspective of science teaching that focuses on development individuals as society members who are aware and critical. Given the rise of scientific and technological culture, it is important for science education to promote conditions for students to participate actively in these issues, and thus being scientifically literate.

In this sense, the language becomes indispensable, since it is the essential element of interaction and communication; it is inherent in society's cultures, including the scientific, establishing itself as a means of production of knowledge as well as to build a social identity.

Considering this, we understand that textual production can be resulted from several interactions occurred not only in the classroom, but also before a framework of enunciation. Thus, from the perspective of Bakhtin and his circle, we propose to investigate these interactions (established during the preparation and implementation of didactic sequence) and their relations with the teacher's mediation and the student's textual production from a didactic sequence. For this we sought to picture the responsive behaviors of the involved subjects by the transcription of speeches and the texts written by the students. By responsive behavior we understand that in a dialogical movement, the intention or attitude of a subject is understood by the other party, and from this understanding it will adopt attitudes in response to the first, and vice versa. These attitudes, by their turn, picture specific responsive behaviors that lead basically to reproduction of knowledge (passive) or to reinterpretation of knowledge (active).

According to the results, we have seen that the teacher's mediation can be influenced by responsive behaviors which are not exclusively given in class. In the case of this research, the interaction with the mediator and the previous contact that the teacher had with the material of the didactic sequence influenced her attitude in the classroom. Furthermore, it was possible to observe that the student in its process of building knowledge during the elaboration of a written text presents stages in which it appropriates third parties speeches and stages in which this speeches' internalization had already become a personal one. In this respect, we conclude that in the process of scientific literacy it is important that the teacher's speech and the material used in class are connected, once the students can reproduce both what is considered scientifically accepted, but also terms and misconceptions. In addition, a material which does not allow creative possibilities for the teacher can restrict its attitude and that of the students in passive behavior.

Keywords: Scientific Literacy, Language, Biology Education, Ecology. 


\section{SUMÁRIO}

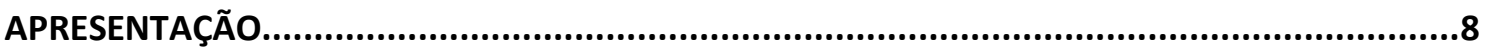

CAPÍTULO 1. ENSINO DE CIÊNCIAS E LINGUAGEM ……………...................................11

1.1. ALFABETIZAÇÃO CIENTÍFICA, LINGUAGEM E ESCRITA................................................ 11

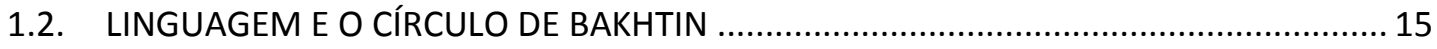

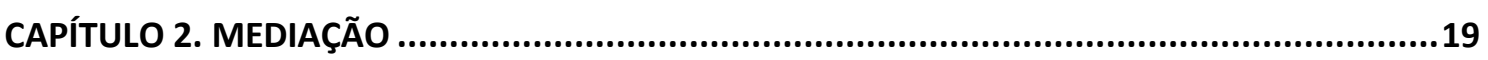

CAPÍTULO 3. PROBLEMA DE PESQUISA E OBJETIVOS.....................................................22

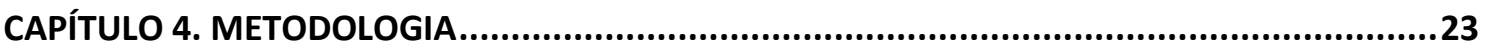

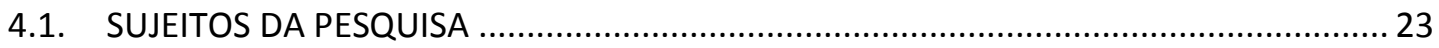

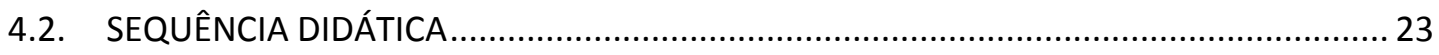

4.2.1. TEMA CENTRAL DA SEQUÊNCIA DIDÁTICA.................................................... 25

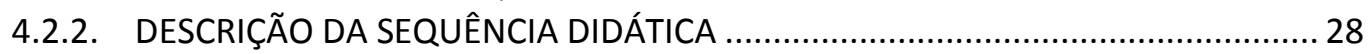

4.3. PREPARAÇÃO E APLICAÇÃO DA SEQUÊNCIA DIDÁTICA …………………………......... 30

4.4. CONSTRUÇÃO DOS DADOS DA PESQUISA ……………………………………….... 31

4.4.1. IDENTIFICAÇÃO E (RE)NOMEAÇÃO DOS SUJEITOS EM TURNOS DE FALA TRANSCRITOS E TEXTOS ESCRITOS DOS ALUNOS............................................. 31

4.4.2. ANÁLISE INTERACIONAL ……………………………............................... 31

4.4.3. ANÁLISE CONCEITUAL...…………………………………………………..... 36

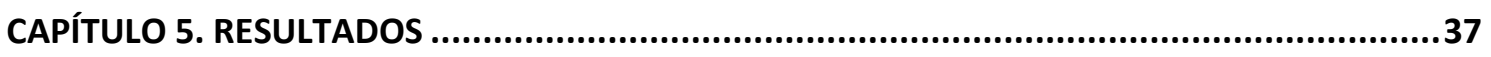

5.1. MEDIADOR-PROFESSORA-TEXTO ……………………………………………..... 37

5.2. ALUNOS-PROFESSORA-TEXTO ………………………………………………….... 47

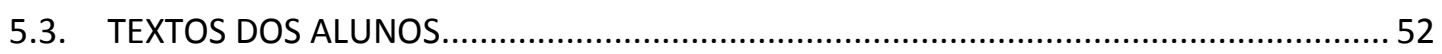

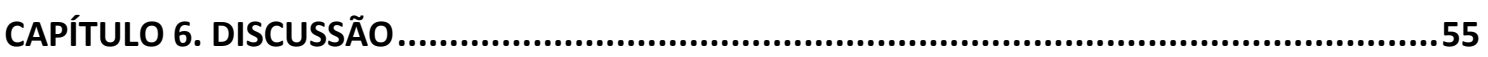

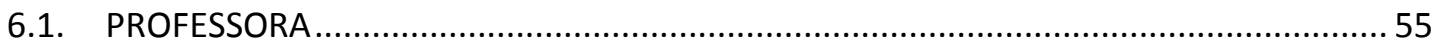

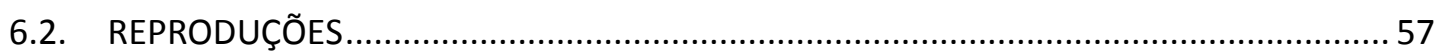

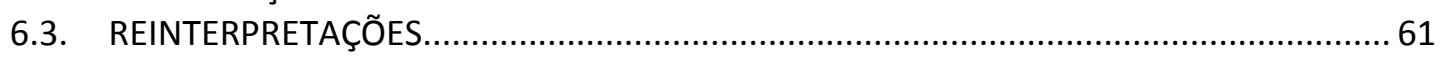

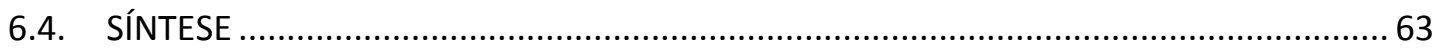

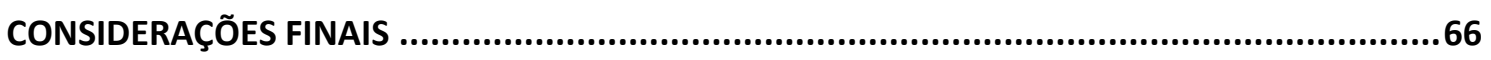

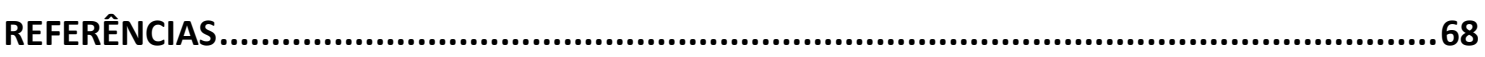

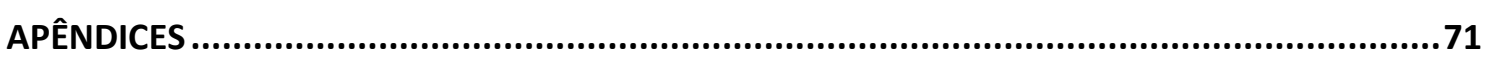

APÊNDICE 1 - SEQUÊNCIA DIDÁTICA ......................................................................... 71

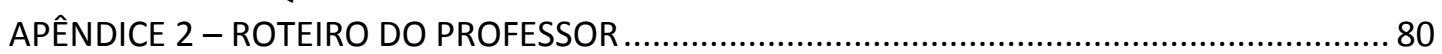

APÊNDICE 3 - TRANSCRIÇÃO DA PREPARAÇÃO: MEDIADOR-PROFESSORA............................. 88

APÊNDICE 4 - TRANSCRIÇÃO DA APLICAÇÃ̃O DA SEQUÊNCIA DIDÁTICA ……………………... 96

APÊNDICE 5 - ANÁLISE DA PREPARAÇÃO: MEIDADOR-PROFESSORA ……………………....111

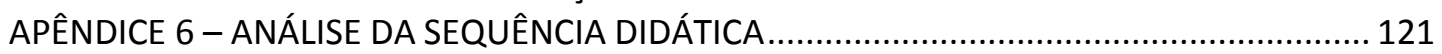

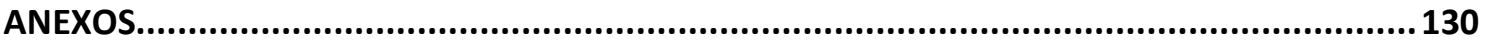

ANEXO 1 - TEXTOS DOS ALUNOS ………………………………………………..... 130 


\section{APRESENTAÇÃO}

O percurso desta dissertação tem origem com a parceria entre o grupo de pesquisa LINCE (Linguagem no Ensino de Ciências) do Laboratório de Ensino de Biologia coordenado pelo Prof. Dr. Marcelo Tadeu Motokane e o LABTROP (Laboratório de Florestas Tropicais) coordenado pelo Prof. Dr. Alexandre Adalardo de Oliveira. Esse vínculo foi estabelecido por meio do projeto "Recuperação e Conservação dos Ecossistemas de Restingas do Litoral Sul de São Paulo" (Conserva Restinga) cuja proposta, entre outras, era aproximar educadores (do entorno do município de Cananéia, SP) do conhecimento científico gerado a partir das pesquisas realizadas nesse projeto.

A primeira ideia de projeto de pesquisa era investigar a forma como os educadores daquela região argumentavam em cursos de formação continuada, uma vez que as discussões sobre argumentação no grupo LINCE estavam bastante latentes.

Ao mesmo tempo, outro grupo de pesquisa, o GEPEB (Grupo de Estudo e Pesquisa em Ensino de Biologia) coordenado pela Profa. Drá. Silvia F. Trivelato, também tinha o mesmo foco de discussão, a argumentação.

Unindo interesses em comum, iniciamos uma parceria entre os grupos, cujo objetivo era discutir e elaborar sequências didáticas capazes de desenvolver habilidades argumentativas.

Inicialmente, pensamos na elaboração de uma sequência didática que tratasse do conhecimento científico referente ao projeto Conserva Restinga, ou seja, a sequência didática seria elaborada tendo em vista o curso de formação dos educadores. Mas ao longo do projeto, por conta de impasses burocráticos que dificultaram as execuções dos cursos de formação, mudamos o nosso foco para a sala de aula no ensino fundamental.

Nos encontros do LINCE com o GEPEB discutimos nossas perspectivas acerca do que era uma sequência didática e de que maneira poderíamos desenvolver habilidades argumentativas dos alunos. Definimos nosso referencial teórico (discutido 
no capítulo metodológico desta dissertação) e depois de inúmeras versões finalizamos a sequência didática.

Enfim, a aplicação da sequência didática foi em uma escola de ensino fundamental do município de Dumont, SP. E o nosso foco de análise passou a ser a influência da mediação docente na construção de argumentos dos alunos.

O primeiro olhar para os dados da pesquisa nos deixou um tanto inquietos com relação à estrutura dos argumentos que tentávamos encontrar nos textos escritos dos alunos. Ao mesmo tempo discutíamos nas reuniões do grupo se a busca por argumentos não estavam sendo de certa forma "forçados" ou se o nosso olhar já não estava condicionado em nossas análises.

A resposta disso veio no exame de qualificação, fazendo-nos repensar se o que encontramos eram argumentos ou explicações.

Outras inquietações surgiram: Por que somente olhar para os argumentos? As explicações não são tão importantes quanto?

$\mathrm{Na}$ ciência, tanto argumentos quanto explicações são fundamentais no processo de construção do conhecimento. O enriquecimento científico está justamente no desafio de transpor um determinado conhecimento em outras situações as quais elas se aplicam, ou seja, explicar um mesmo fenômeno em contextos diferentes.

Dessa forma, chegamos ao consenso de que desenvolver habilidades explicativas também são importantes para o processo de alfabetização científica.

Pensando nisso, a pesquisa caminhou no sentido de tentarmos compreender alguns fatores envolvidos nesse processo da alfabetização científica: das interações ocorridas antes e durante a aula às explicações escritas dos alunos.

Iniciamos a dissertação trazendo nos dois primeiros capítulos o quadro teórico da pesquisa. No capítulo 1, procuramos esclarecer as relações entre a alfabetização científica, a linguagem e a escrita sob a perspectiva de Mikhail Bakhtin e seu círculo. No capítulo seguinte (CAPÍTULO 2) discutimos o conceito de mediação a partir dos pressupostos de Vygotski. No CAPÍTULO 3 tratamos dos objetivos e questão de pesquisa, buscando relacionar os objetivos específicos em vista de responder: como é 
a mediação da professora em uma aula de Ecologia e como isso pode influenciar na produção de explicações escritas pelos alunos?

No capítulo metodológico (CAPÍTULO 4) abordamos todas as etapas na construção dos dados da pesquisa. Desde o desenvolvimento da sequência didática e sua forma de pré-aplicação e aplicação; até a criação categorias. O capítulo 5 descreve os resultados obtidos e no capítulo 6, discutimos os resultados apresentados. Por fim, no capítulo 7 discutimos algumas considerações finais acerca da análise realizada referindo-se à resposta da questão de pesquisa proposta. 


\section{CAPÍTULO 1. ENSINO DE CIÊNCIAS E LINGUAGEM}

A alfabetização científica e a linguagem são questões indissociáveis no processo de ensino de ciências.

Entendemos que ser alfabetizado cientificamente é antes de tudo ser capaz de utilizar, conscientemente, o conhecimento científico em diversas questões da sociedade, agindo como um cidadão crítico. E para isso é importante que o sujeito reconheça as particularidades da cultura científica.

Nesse sentido, a linguagem torna-se imprescindível, uma vez que a linguagem é o elemento essencial de interação e comunicação; é intrínseca nas culturas da sociedade, inclusive na cultura científica, constituindo-se como meio de produção do conhecimento e também de construção de uma identidade social.

Sendo assim, assumimos neste trabalho, uma perspectiva dialógica da linguagem em que os processos comunicativos são muito mais do que palavras transmitidas de um sujeito para outro, a linguagem é papel constitutivo dentro de uma cultura. Ou seja, por meio da linguagem, o homem não só veicula informações, mas também permite aos sujeitos se representarem a si mesmos, aos outros e ao mundo (PANCERA, 2002).

\subsection{ALFABETIZAÇÃO CIENTÍFICA, LINGUAGEM E ESCRITA}

O ponto de partida deste trabalho é a perspectiva do ensino de ciências que tem como foco o desenvolvimento de indivíduos como membros conscientes e críticos na sociedade. Diante da ascensão da cultura científica e tecnológica na sociedade, é importante que a educação científica promova condições para que os alunos participem ativamente dessas questões, sendo dessa forma alfabetizados cientificamente.

Nesse sentido, o termo Alfabetização Científica é mencionada com bastante frequência na literatura, existindo, porém, diversas compreensões acerca do seu termo (NORRIS; PHILLIPS, 2003): “Letramento Científico" (SANTOS; MORTIMER, 2001), “Alfabetização Científica” (LORENZETTI; DELIZOICOV, 2001; CHASSOT, 2000), e 
também aqueles que utilizam a expressão "Enculturação Científica" (DRIVER; NEWTON; OSBORNE,2000).

Embora os termos sejam diferentes, existe um ponto comum que é a formação em ciências voltada para a cidadania e a atuação na sociedade como mostram Sasseron e Carvalho (2011) em um estudo sobre essas definições.

O termo "Alfabetização Científica" utilizado nessa pesquisa tem em vista a ideia de alfabetização de Paulo Freire (1980, p.111): “[...] a alfabetização é mais que o simples domínio psicológico e mecânico de técnicas de escrever e ler. É o domínio destas técnicas em termos conscientes."

Nesse sentido, Sasseron e Carvalho (2008) enfocam a importância e o planejamento do ensino de ciências para a formação de cidadãos capazes de tomar decisões e representar a sociedade criticamente e conscientemente frente aos assuntos que ligam a sociedade, a ciência e o ambiente. Ou seja, ser alfabetizado cientificamente é compreender os fenômenos que acontecem ao nosso redor, saber relacionar esses fenômenos com suas possíveis causas científicas, avaliar possibilidades de intervenção e tomar decisões alicerçadas nos valores de um contexto social (JIMÉNEZ-ALEIXANDRE, 2004)

Sendo assim, ser alfabetizado cientificamente não significa ser um cientista ou possuir todo conhecimento sobre as ciências, significa ter acesso a um conjunto de ações que caracterizam a cultura científica e ser capaz de tomar decisões conscientemente. Mas o que caracteriza a cultura científica?

Considerar a ciência como cultura, é assumir que ela possui características próprias que a distingue de outras culturas. Por exemplo, a cultura científica possui regras, valores e linguagem que the são peculiares (CACHAPUZ et al., 2005). Assim como também são peculiares seus modos de produção, validação e divulgação do conhecimento científico por ela gerado: o conhecimento científico é construído na medida em que há o compartilhamento de experiências entre os pares dessa comunidade, ou seja, é socialmente construído e validado (DRIVER et al., 1999), e para que isso seja possível, é preciso que exista uma linguagem comum. 
A linguagem científica possui uma estrutura particular e características específicas, indissociáveis do próprio conhecimento científico (VILLANI; NASCIMENTO, 2003). Segundo Sasseron (2008), noções, idéias e conceitos científicos são partes essenciais para que os indivíduos dessa cultura possam ser capazes de participar de discussões e se comunicar.

Sobre as diferenças entre a linguagem do senso comum e a científica, Mortimer, Chagas e Alvarenga (1998) discutem algumas características próprias que as distinguem. Segundo os autores, as características da linguagem científica não surgiram de um único momento determinado. Pelo contrário, essas características são estabelecidas ao longo de um processo. Tomando como base os trabalhos de Halliday e Martin (1993) e Bruner (1991), os autores traçam o perfil da linguagem científica e da linguagem comum:

$\mathrm{Na}$ linguagem comum as narrativas que relatam sequências lineares de eventos são predominantes, existe uma ordem sequencial que é estabelecida e mantida. Já a linguagem científica é predominantemente estrutural, os processos são transformados em grupos nominais ligados por verbos. Na linguagem científica, o agente normalmente está ausente, sem a perspectiva de um narrador. Na linguagem cotidiana, o narrador está sempre presente.

Mortimer, Chagas e Alvarenga (1998) exemplificam essas distinções em frases que possuem o mesmo sentido.

$\mathrm{Na}$ linguagem cotidiana: quando colocamos sal em água e aquecemos, conseguimos dissolver uma maior quantidade do que em água fria.

$\mathrm{Na}$ linguagem científica: o aumento de temperatura provoca um aumento da solubilidade do sal.

Os autores ressaltam que na primeira frase, o agente está presente, os verbos designam ações efetuadas por esse agente, e os fatos são apresentados numa sequência que garante a linearidade do discurso. Na segunda frase, não há agente devido à nominalização dos processos. Assim, as ações antes designadas por verbos são transformadas em grupos nominais (aumento de temperatura e aumento da 
solubilidade do sal). O verbo (provoca) não indica a ação, e sim uma relação entre os dois processos nominalizados.

Nesse sentido, Halliday e Martin (1993) referem-se a esse processo como uma "metáfora gramatical", na qual, no lugar da substituição de um nome por outro ocorre a substituição de uma classe ou estrutura gramatical por outra.

Dessa forma, os autores reforçam que a linguagem cotidiana é muito mais próxima da fala e a linguagem científica aproxima-se da linguagem escrita, o que pode dificultar tanto o ensino como a aprendizagem das ciências.

Sendo assim, devido a essas especificidades da linguagem científica, fica evidente que alfabetização científica não ocorre espontaneamente. Pelo contrário, é um processo no qual as habilidades que caracterizam a cultura científica necessitam ser trabalhadas e desenvolvidas.

Dessa forma, cabe ao ensino de ciências promover condições para que os alunos tenham acesso à essa forma especial de produção de conhecimento (CAPECCHI; CARVALHO, 2004) não se limitando apenas à memorização de conceitos e definições, mas possibilitando a apropriação de um discurso em que conceitos e definições se relacionam entre si e que, além disso, são utilizados para produzir significados em contextos reais debatidos na sociedade.

Partindo dessas reflexões entendemos que a escrita tem papel relevante tanto na comunidade científica quanto no processo de alfabetização científica, uma vez que "a escrita exige reflexão, seleção de conteúdos e de formas de expressão próprias da linguagem científica para comunicar ideias elaboradas" (MÁRQUEZ; PRAT, 2005, P.43)

Oliveira \& Carvalho (2005) reforçam que a discussão de ideias e a escrita de textos nas aulas de ciências são ferramentas importantes para a criação de um sistema conceitual coerente. E que a linguagem escrita tende a ser mais objetiva do que a discussão de ideias nas aulas de ciências, já que exige uma carga cognitiva maior na sua execução. Dessa forma, escrever torna-se uma ferramenta importante por organizar e consolidar o conhecimento de forma mais estruturada. 


\subsection{LINGUAGEM E O CÍRCULO DE BAKTHIN}

Entendemos a linguagem como elemento essencial de interação e comunicação: é intrínseca nas culturas da sociedade, inclusive na cultura científica, constituindo-se como meio de produção do conhecimento e também de construção de uma identidade social. Nesse sentido, assumimos neste trabalho, uma perspectiva dialógica do Círculo de Bakhtin em que os processos comunicativos são muito mais do que palavras transmitidas de um sujeito para outro tendo a linguagem como papel constitutivo dentro de uma cultura. Ou seja, por meio da linguagem, o homem não só veicula informações, mas também permite aos sujeitos se representarem a si mesmos, aos outros e ao mundo (PANCERA, 2002).

O desenvolvimento das ideias de Mikhail Bakhtin e seu círculo se encontram em um cenário baseado no materialismo histórico do marxismo em que a estrutura socioeconômica e as relações de produção determinam como a cultura, o regime político, a moral e os costumes se configuram.

É nesse quadro que suas ideias se constituem: a linguagem como fenômeno histórico, social e cultural. Ou seja, deve-se levar em conta a história, a cultura, a vida e o conhecimento compartilhado dos participantes, e dos contextos sociais nos quais estão inseridos.

Assim, Bakhtin reconhece a importância do outro para a própria existência e para a linguagem. Trata-se da essência dialógica, visto que o outro tem função extremamente relevante na construção de significados e também no estabelecimento da própria consciência social e individual.

Sendo assim, a linguagem é entendida como ferramenta da interação verbal, o que implica entendê-la como um fenômeno que se realiza por meio da enunciação. $O$ enunciado dialógico pode ser definido como unidade real da comunicação discursiva: não são apenas palavras ou sentenças gramaticais que determinam o discurso, mas também a situação real na qual ele ocorre (BRAIT; MELO, 2005).

Ou seja, deve-se levar em conta a história, a cultura, a vida e o conhecimento compartilhado dos participantes, e dos contextos sociais nos quais estão inseridos. A 
palavra empregada como apenas um item dicionarizado não terá significado, só apresentará sentido se reconhecida em um contexto específico.

Na realidade, não são palavras o que pronunciamos ou escutamos, mas verdades ou mentiras, coisas boas ou más, importante ou triviais, agradáveis ou desagradáveis, etc. A palavra está sempre carregada de um conteúdo ou de um sentido ideológico ou vivencial. É assim que compreendemos as palavras e somente reagimos àquelas que despertam em nós ressonâncias ideológicas ou concernentes à vida. (BAKHTIN, 2006, p.96)

Os sujeitos só se comunicam por meio de enunciados quando conhecem e compreendem o contexto, ou seja, quando compartilham universos, conhecimentos, pressupostos e sentidos (BAKHTIN, 2006). Assim, o centro organizador da enunciação não é interior, mas exterior, está situado no meio social, nas relações sociais.

Dessa forma, enunciação é o produto da interação de dois indivíduos socialmente organizados, é a junção de dois elementos: o linguístico e o social; tem um sentido único e definido já que é propriedade de um contexto específico e que faz sentido apenas no momento da ocorrência (PANCERA, 2002), ou seja, segundo Bakhtin (2006), o momento social e histórico que Ihe deu origem e que compreende toda uma situação e os elementos que a compõem.

Nesse aspecto, Bakhtin considera que texto e enunciação estão no mesmo plano. O texto situa-se inserido na produção cultural, aberto à simultaneidade de visões; ao se caracterizarem como produtos da atividade humana, é possível perceber sua vinculação às necessidades, aos interesses e às condições de funcionamento das formações sociais em que são produzidos (BRAGA; MORTIMER, 2003).

O texto não é um objeto, sendo por esta razão impossível eliminar ou neutralizar nele a segunda consciência, a consciência de quem toma conhecimento dele. [...] por trás de todo texto, encontra-se o sistema da língua; no texto, corresponde lhe tudo quanto é repetitivo e reproduzível, tudo quanto pode existir fora do texto. Porém, ao mesmo tempo, cada texto (em sua qualidade de enunciado) é individual, único e irreproduzível, sendo nisso que reside seu sentido (seu desígnio, aquele para o qual foi criado). (BAKHTIN, 1997, p.334) 
A partir desta concepção, qualquer enunciação, ainda que na forma da escrita, é construída como uma resposta a enunciações anteriores. É o que Bakhtin denomina responsividade: a capacidade que participantes de uma situação comunicativa têm de responder aos discursos manifestados. Desta forma, o conceito de responsividade funde duas noções associadas à ideia de responder. No agir, o sujeito responde, em primeiro lugar, porque compreende e dá uma resposta e em segundo lugar, porque assume uma responsabilidade e uma posição.

Tratar do caráter responsivo das práticas de linguagem implica em pensar no papel fundamental que o outro, isto é, o interlocutor socialmente situado, exerce nos processos de interação verbal (MENEGASSI, 2009). Ou seja, sempre que se desenvolve uma enunciação, é esperada por parte do outro uma resposta. Nesse sentido, Bakhtin reforça que na alternância de sujeitos falantes, o outro não pode se considerado como um destinatário passivo que se limita a compreender o enunciado do sujeito locutor.

Ao levar isso em conta, o caráter responsivo das práticas de linguagem perpassa por vários conceitos bakhtinianos, desde a interação verbal, a palavra, o outro, os enunciados e até mesmo os gêneros do discurso (MENEGASSI, 2009). Nesse sentido, o signo, na ótica bakhtiniana, não apresenta valor absoluto fora da interação social e, por isso, é um elemento sujeito às critérios ideológicos. Dessa forma, pode-se dizer que a compreensão encontra-se impregnada de significações ideológicas, visto que a compreensão não se reduz ao reconhecimento/ identificação de uma forma linguística utilizada pelo outro, mas se trata de compreender a sua significação numa enunciação particular (ANGELO, 2010).

Angelo e Menegassi (2011) ressaltam ainda a necessidade de se entender a compreensão em seus dois polos: o conteúdo interior (aquilo que é formado e organizado no psiquismo do indivíduo) e a objetivação exterior (aquilo que é exteriorizado para o outro ou também para si próprio). Ambos são igualmente elaborados e exprimíveis por meio de signos, portanto, modelados pela ideologia do grupo a que pertencem os interlocutores. Menegassi (2009) ressalta ainda que, o discurso interior, tanto do locutor como do outro, é resultado da internalização e da reconstrução das práticas sociais das quais o sujeito toma parte ao longo de sua 
existência. Nesse discurso, torna-se possível vislumbrar também um dos princípios geradores da responsividade, visto que ela constitui-se como resposta interna aos processos interiorizados.

Esses processos, por sua vez, não são movidos apenas pela livre vontade do locutor. O discurso interior, que organiza e faz ecoar os processos internalizados, tanto em termos vivenciais quanto linguísticos, não é responsável exclusivo por aquilo que se enuncia. Ao contrário, a enunciação é fortemente condicionada pela finalidade do discurso, pelo contexto e pelos interlocutores. Desse modo, não importa apenas a individualidade daquele a quem a palavra é endereçada, mas também a posição social que ele ocupa em relação ao sujeito de quem a palavra procede e o entorno no qual se encontram inseridos (MENEGASSI, 2009).

Nesse contexto acerca do conceito de compreensão, Bakhtin afirma que toda compreensão é de natureza ativa, ou seja, possibilita que o ouvinte se torne falante, favorecendo o elo que constitui a interação verbal:

[...] o enunciado se constrói levando em conta as atitudes responsivas, em prol das quais ele, em essência, é criado. O papel dos outros, para quem se constrói o enunciado, é excepcionalmente grande, como já sabemos. Já dissemos que esses outros, para os quais o meu pensamento pela primeira vez se torna um pensamento real (e deste modo também para mim mesmo), não são ouvintes passivos mas participantes ativos da comunicação discursiva. Desde o início, o falante aguarda a resposta deles, espera uma ativa compreensão responsiva. É como se todo enunciado se construísse ao encontro dessa resposta. (BAKHTIN, 2006, p. 301)

Nesse sentido, o interlocutor torna-se uma particularidade fundamental para a constituição de enunciados e também para a realização do processo de internalização do conhecimento e consequentemente, para formação do indivíduo como sujeito ativo no discurso. 


\section{CAPÍTULO 2. MEDIAÇÃO}

É em um contexto de geração e apropriação de saberes socialmente construídos que a educação surge como um importante fator para o desenvolvimento de sujeitos culturais. Nesse contexto, o processo de ensino e aprendizagem depende da interação entre sujeitos, viabilizada pela mediação de sistemas simbólicos, construídos ao longo da história da humanidade. É nesse sentido que este capítulo traz as obras “ A Formação Social da Mente" (1998) e "Pensamento e Linguagem" (1993), em que Vygotski desenvolveu seus estudos a respeito do desenvolvimento humano, para discutir a respeito da influência do meio sócio-histórico-cultural no desenvolvimento da estrutura cognitiva do indivíduo.

Vygotski parte dos fundamentos do pensamento marxista que apresenta a dialética como método dos estudos dos fenômenos como processo em contínuo movimento e transformação. Nessa abordagem, o ser humano e o meio sócio-cultural estão em constante interação estabelecendo trocas recíprocas durante toda sua existência.

A construção do conhecimento e o próprio desenvolvimento humano para Vygotski não é apenas baseado nas funções psicológicas de suporte biológico, ou seja, de atividades cerebrais, mas também fundamentada nas relações sociais entre o indivíduo e o mundo exterior. Assim, o homem se transforma de um ser biológico em sócio-histórico num processo em que a cultura é parte essencial da constituição da natureza humana.

Nesse contexto social, histórico e cultural, o funcionamento intelectual dos sujeitos, ou seja, o desenvolvimento das funções psicológicas superiores (atividades mentais mais complexas tais como o pensamento, a capacidade de imaginar e planejar ações, que se diferenciam de mecanismos mais elementares como ações reflexas, automáticas e associações simples) depende das interações estabelecidas, interações essas que são mediadas por ferramentas auxiliares de suas atividades tais como os instrumentos de trabalho e os signos. 
Sobre o trabalho, Vygotski considera como fator que diferencia o ser humano de outros seres vivos. O trabalho traz a necessidade do homem criar ferramentas ou instrumentos auxiliares as quais se interpõem entre o sujeito e o objeto de trabalho, mediando a sua relação com o mundo e dessa forma se constituir como sujeito cultural.

Da mesma forma que o instrumento mediatiza a atividade laboral do homem, o signo mediatiza não só o pensamento, mas também o próprio processo social. Nesse sentido, a linguagem é um dos principais mediadores na formação e no desenvolvimento das funções psicológicas superiores, constituindo-se num sistema simbólico, elaborado no curso da história social do homem.

De acordo com Rego (1998), a linguagem constitui o sistema de mediação simbólica que funciona como instrumento de comunicação e planejamento. E é justamento pela sua função comunicativa que o indivíduo se apropria do mundo externo, pois é pela comunicação estabelecida na interação que ocorrem negociações e reinterpretações das informações, dos conceitos e significados.

A apropriação desse mundo externo, por sua vez, não ocorre de forma direta, ou seja, não há transferência de uma atividade externa para um plano interno. E nem mesmo, o desenvolvimento das funções psicológicas ocorre de forma acumulativa, mas sim com uma série de transformações qualitativas e dialéticas. De acordo com Blanck (1996) elas são formadas em estágios, sendo cada um deles constituído por um processo complexo de desintegração e integração.

Quando os indivíduos as interiorizam, passam a ter acesso a significações que, por sua vez, servirão de base para que possam significar suas experiências, e serão estas significações resultantes que constituirão suas consciências, mediando, desse modo, suas formas de sentir, pensar e agir.

De acordo com Vygotski, as relações entre desenvolvimento e aprendizagem ocupam lugar de destaque, principalmente, na educação pois embora a criança inicie sua aprendizagem muito antes do ensino formal, a aprendizagem escolar introduz elementos novos no seu desenvolvimento. 
Assim, Vygotski considera a existência de dois níveis de desenvolvimento. Um corresponde a tudo aquilo que a criança pode realizar sozinha e o outro, às capacidades que estão se construindo; ou seja, refere-se a tudo aquilo que a criança poderá realizar com a ajuda de outra pessoa mais experiente. Entre esses dois níveis, há uma zona de transição, na qual o ensino deve atuar, pois é pela interação com outras pessoas que serão ativados os processos de desenvolvimento. E assim esses processos serão interiorizados e farão parte do primeiro nível de desenvolvimento, convertendo-se em aprendizagem e abrindo espaço para novas possibilidades de aprendizagem.

Convém ressaltar que o autor embora reconheça a importância das relações com indivíduos mais experientes para o desenvolvimento do sujeito, a interiorização não se desenvolve intuitivamente. Pelo contrário, ocorre por meio de um processo dialógico complexo dependente de uma série de transformações qualitativas que ocorrem no indivíduo à medida que ele vive diferentes experiências.

Para o estudo da mediação por meio da linguagem, Smolka (1991) propõe duas dimensões: a primeira é a dimensão discursiva (mediação pela palavra); e a outra a dimensão pedagógica (mediação pelo outro). Nas situações de interação em sala de aula (professor-aluno-conhecimento) a mediação ocorre diante das duas dimensões, pela palavra e pelo outro propiciando a construção e a apropriação de conhecimentos.

Dessa forma, a produção de conhecimento decorrente do espaço escolar se configura numa relação estabelecida em um diálogo coletivo entre professor e alunos. Cabendo ao professor orientar e direcionar a prática educativa intermediando o processo de internalização dos conhecimentos científicos. 


\section{CAPÍTULO 3. PROBLEMA DE PESQUISA E OBJETIVOS}

Frente aos referenciais apresentados anteriormente, temos condições para compreendermos que a produção de um texto pode ser resultado de várias interações ocorridas não apenas em sala de aula, mas sim diante de um quadro enunciativo que obviamente não será esgotado nessa pesquisa.

Nosso olhar está voltado para os comportamentos responsivos da professora e dos alunos. Temos a premissa de que o comportamento responsivo dos sujeitos diante de interações pode influenciar o andamento e o resultado de uma aula.

Nesse sentido, temos como objetivo geral compreender as interações existentes entre os sujeitos envolvidos no quadro enunciativo em questão, e suas relações com a produção textual dos alunos.

Sendo assim, para os objetivos específicos temos:

a) Identificar atitudes do mediador e da professora, classificando essas atitudes quanto ao comportamento responsivo durante a pré-aplicação da sequência didática.

b) Identificar atitudes da professora e classificar essas atitudes quanto ao comportamento responsivo durante a aplicação da sequência didática.

c) Identificar atitudes dos alunos e classificar essas atitudes quanto ao comportamento responsivo durante aplicação da sequência didática.

d) Identificar atitudes dos alunos e classificar essas atitudes quanto ao comportamento responsivo nas explicações escritas.

e) Analisar as explicações quanto à qualidade conceitual.

Dessa forma, buscamos responder como é a mediação da professora em uma aula de Ecologia e como isso pode influenciar na produção de explicações escritas pelos alunos. 


\section{CAPÍTULO 4. METODOLOGIA}

Inicialmente apresentamos os sujeitos envolvidos pesquisa, em seguida a concepção e o desenvolvimento da sequência didática (SD) trabalhada nesta pesquisa. Posteriormente, apresentamos a descrição da preparação da sequência didática realizada pelo mediador com a professora. E, por fim, apresentamos a aplicação da sequência didática em sala de aula pela professora e os passos da construção de dados da pesquisa:

- identificação e (re)nomeação dos sujeitos em turnos de fala transcritos e textos escritos dos alunos;

- Análise interacional;

- Análise das explicações quanto à qualidade conceitual.

\subsection{SUJEITOS DA PESQUISA}

A seguir descrevemos os sujeitos participantes dessa pesquisa:

a) Mediador: educador do Laboratório de Ensino de Biologia da FFCLRPUSP, 31 anos, 10 anos de magistério, 11 meses como educador.

b) Professora: professora da rede de Ensino do Município de Dumont, SP, participante do grupo de estudos Linguagem e Ensino de Biologia (LINCE); 27 anos, 1 ano de magistério.

c) Total de 26 alunos (entre 12 e 13 anos) do sétimo ano da escola municipal de Dumont, SP.

d) Pesquisadora: Licenciada em Ciências Biológicas, participante do Grupo LINCE.

\subsection{SEQUÊNCIA DIDÁTICA}

De acordo com Masseron (1996), podemos definir uma sequência didática (SD) como "uma sequência de atividades progressivas, planificadas, dirigidas por um tema, um objetivo geral ou por uma produção". 
É nesse sentido que iniciamos uma discussão juntamente com o grupo de estudos Linguagem no Ensino de Ciências (LINCE), do Laboratório de Ensino de Biologia da Faculdade de Filosofia Ciências e Letras de Ribeirão Preto da Universidade de São Paulo (FFCLRP-USP) em parceria com o Grupo de Estudos e Pesquisas em Ensino de Biologia (GEPEB) da Faculdade de Educação da Universidade de São Paulo (FE-USP) acerca do ensino a partir da resolução de problemas estruturados em sequências didáticas com o propósito de promover situações argumentativas e explicativas, além disso, gerando conteúdo com conhecimento científico.

As sequências didáticas produzidas pelo LINCE e GEPEB possuem uma estrutura geral semelhante apoiadas em referenciais teóricos como Guisasola (2006) e Erduran (2006).

Para Guisasola (2006) é importante que uma sequência didática: a) tenha um problema central capaz de realmente aproximar os alunos do conhecimento científico, ganhando a atenção e o interesse destes (e não de um imenso corpo teórico descontextualizado); e b) permita que os estudantes usem a imaginação, criatividade, o discurso (especialmente a argumentação) para responder as questões específicas decorrentes do problema central (propiciando o desenvolvimento de destrezas inerentes ao trabalho científico como: elaboração de hipóteses, interpretação crítica dos dados obtidos à luz de teorias).

Nesse sentido, Erduran (2006) especifica dois principais modelos de atividades: 1) predição-observação-explicação: uma situação problema deve ser pensada na qual os alunos devem levantar e testar hipóteses, construindo argumentos para validar ou refutar explicações sobre o fenômeno em questão e; 2) teorias competitivas: uma pergunta é feita aos alunos e a eles é fornecido um conjunto de dados a respeito do assunto e dois ou mais modelos explicativos para o fenômeno. Nesse tipo de atividade, os alunos devem escolher qual modelo consideram o mais correto, embasando seus argumentos no conjunto de dados fornecidos.

Além desses dois modelos de SD, o mesmo autor propõe passos anteriores à sua aplicação: um sujeito externo à pesquisa atua como mediador esclarecendo o professor dos objetivos da SD, assim como eventuais dúvidas relacionadas à atividade. 
Dessa forma, as sequências didáticas seguem um mesmo padrão estrutural: um objetivo claro tanto para ser trabalhado com os alunos, tanto para fins da pesquisa; um conceito científico específico, pois um tema muito abrangente pode dificultar o aprendizado dos alunos; deste conceito é elaborado um problema central; e deste problema central as atividades da sequência didática são pensadas de forma a aproximar o aluno de práticas comumente utilizadas pela comunidade científica por meio de um dos modelos propostos por Erduran (2006).

Uma próxima etapa é a negociação da sequência didática. Nessa fase, contamos com um sujeito externo à pesquisa fazendo a mediação, ou seja, ele esclarece ao professor os objetivos do pesquisador e da sequência didática, esclarecendo dúvidas. Um ponto importante nessa fase é a adaptação da sequência didática ao grupo específico de alunos os quais o professor atuará. Nesse sentido, o mediador negocia a possibilidade de adequações da sequência didática para atender a esses alunos, pois o conteúdo e as atividades podem não garantir por si só que o objetivo da sequência didática seja alcançado.

Assim, o mediador deixa claro que cada escola e cada turma têm suas particularidades, e é essencial que o professor, que é conhecedor dessas particularidades, faça alterações na sequência didática para que atenda às demandas de cada turma.

\subsubsection{TEMA CENTRAL DA SEQUÊNCIA DIDÁTICA}

O tema da sequência didática dessa pesquisa é a Sucessão Ecológica. Esse tema foi escolhido devido ao estreitamento de relações estabelecidas com o Laboratório de Florestas Tropicais do Instituto de Biociências da Universidade de São Paulo (LabTropIB-USP) diante do projeto "Conserva Restinga" (como citado na apresentação).

Diante desse tema tão abrangente, escolhemos um conceito específico para ser trabalhado: a influência de fatores abióticos e estruturas adaptativas na composição vegetal da Restinga. 
Na Restinga, a proximidade do mar atua como fator fortemente seletivo para a instalação e crescimento da vegetação. As plantas são sujeitas a: ventos fortes carregados de partículas de sal, luminosidade excessiva, escassez de nutrientes, grande instabilidade e reduzida disponibilidade de água devido à alta permealidade dos terrenos arenosos. Conforme se distancia do mar, observa-se que há modificações na vegetação as quais refletem as condições do solo que se tornam mais estáveis, firmes, com menor permeabilidade e maior disponibilidade de nutrientes. As fisionomias tornam-se mais complexas a medida que estão mais distantes do mar: de grandes quantidades de poucas espécies na região das praias e dunas a grandes quantidades de várias espécies nas Florestas de Restingas próximas à encosta das montanhas (SUGIYAMA, 1998).

Sendo assim, delineamos o objetivo central da sequência didática: o desenvolvimento de habilidades de leitura de textos descritivos e escrita de textos explicativos baseados em conhecimento científico. Para isso, entre os modelos apresentados por Erduran (2006), escolhemos o modelo predição-observaçãoexplicação.

Na comunidade científica é comum entre os pesquisadores o trabalho com a leitura de textos descritivos de conteúdos que já são aceitos e compartilhados. O enriquecimento científico está justamente no desafio de transpor um determinado conhecimento em outras situações as quais elas se aplicam, ou seja, em contextos diferentes. Nesse sentido, o problema da sequência didática foi pensado para que o aluno fizesse uso das informações descritas no texto de forma implícita para resolver a questão debatida.

A questão, por sua vez, foi considerada de uma situação que envolvesse um assunto debatido na sociedade atual: a elevação do nível do mar e suas consequências. Dessa forma, aproximamos o aluno de questões que estão na mídia e, além disso, envolvemos discussões no âmbito da ciência que não estão totalmente distantes da realidade desses alunos.

De modo geral (QUADRO 1), diante da modificação da vegetação de um determinado local em consequência da elevação do nível do mar, o aluno, por meio 
das descrições dessas vegetações contidas em um texto de apoio, tem condições de relacionar a existência de estruturas adaptativas com a modificação do meio abiótico por conta do aumento do nível do mar. Segue a seguir a descrição detalhada da sequência didática (APÊNDICE 1).

Quadro 1. Resumo da sequência didática.

\begin{tabular}{|c|c|}
\hline OBJETIVOS & $\begin{array}{l}\text { Relacionar conceitos ecológicos já descritos na comunidade científica } \\
\text { na resolução de um problema ambiental, desenvolvendo habilidades } \\
\text { argumentativas escritas dos alunos. }\end{array}$ \\
\hline $\begin{array}{l}\text { CONTEÚDO } \\
\text { CIENTIÍFICO }\end{array}$ & $\begin{array}{l}\text { Relações entre fatores abióticos e estruturas adaptativas de plantas da } \\
\text { Restinga, especificamente o fator seletivo da proximidade do mar na } \\
\text { instalação e crescimento da vegetação. }\end{array}$ \\
\hline & ETAPAS DA SEQUÊNCIA DIDÁTICA \\
\hline CONTEXTUALIZAÇÃO & $\begin{array}{l}\text { Situação envolvendo um assunto debatido na sociedade atual: a } \\
\text { elevação do nível do mar e suas consequências. }\end{array}$ \\
\hline $\begin{array}{l}\text { LEVANTAMENTO DE } \\
\text { HIPÓTESES }\end{array}$ & $\begin{array}{l}\text { O que poderia acontecer com áreas de vegetação preservadas diante } \\
\text { da elevação do nível do mar? } \\
\text { A partir de conhecimentos prévios, os alunos escolhem e justificam } \\
\text { entre duas opções: é afetada ou não é afetada. }\end{array}$ \\
\hline OBSERVAÇÃO & $\begin{array}{l}\text { A partir de imagens de satélite, os alunos observam uma região } \\
\text { modificada pela elevação do nível do mar: onde antes havia uma } \\
\text { vegetação predominantemente arbustiva, após quinze anos passa a } \\
\text { apresentar herbáceas com mais frequência. }\end{array}$ \\
\hline EXPLICAÇÃO & $\begin{array}{l}\text { Com base em um texto de apoio cujo conteúdo é a descrição de } \\
\text { características das formações vegetais da restinga, os alunos } \\
\text { respondem: } \\
\text { 1. Por que, com a aproximação do mar, a vegetação herbácea } \\
\text { começou a aparecer com mais frequência onde antes } \\
\text { predominava a vegetação arbustiva? } \\
\text { 2. Como se deu esse processo? }\end{array}$ \\
\hline DISCUSSÃO & $\begin{array}{l}\text { Retomada das ideias prévias dos alunos na fase } 1 \text { contrastando com as } \\
\text { ideias ao fim da fase } 3 \text {, verificando se ocorreram mudanças de } \\
\text { concepções ou então, o quanto as explicações tornaram-se mais } \\
\text { completas e com conteúdo científico. }\end{array}$ \\
\hline
\end{tabular}




\subsubsection{DESCRIÇÃO DA SEQUÊNCIA DIDÁTICA}

A primeira atividade da sequência didática tem início com um trecho de um artigo publicado no Jornal da Ciência que traz dados referentes à elevação do nível do mar e suas consequências para as cidades litorâneas.

Em seguida, fotos ilustram a localização dessas cidades (planícies litorâneas) e o contraste entre uma planície ocupada pela cidade e outra com a vegetação de Restinga ainda preservada. Assim, os alunos são instigados a refletir sobre o que poderia acontecer com as áreas preservadas em consequência da elevação do nível do mar, já que quase não se discute isso na mídia, ao contrário das amplas discussões realizadas acerca da destruição de cidades litorâneas em decorrência desse aumento do nível do mar.

O objetivo da próxima etapa é resgatar conhecimentos prévios do aluno desenvolvendo a capacidade escrita do aluno de realizar previsões.

(1) A vegetação não é afetada, pois

Se a aproximação do mar não afeta a vegetação, então esperamos que

OU

(2) A vegetação pode ser afetada, pois

Se a aproximação do mar afeta a vegetação, então esperamos que

Após essa atividade, inicia-se a atividade 2 em que o aluno tem em mãos uma sequência de fotos (dados) que corroboram uma das hipóteses propostas anteriormente.

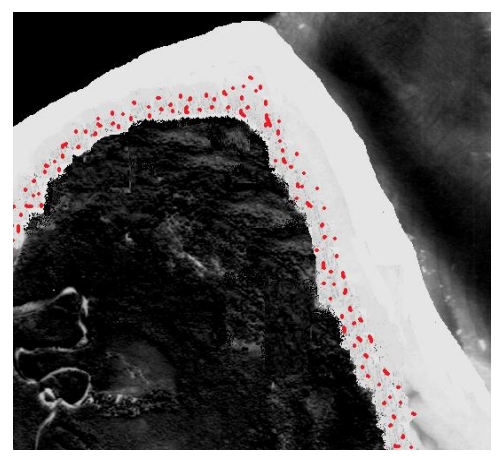

Antes

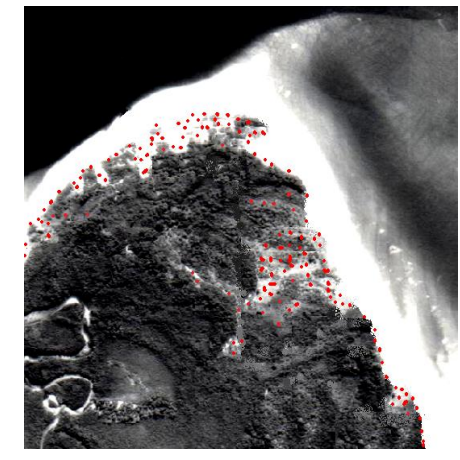

Quinze anos depois
VEGETAÇÃo ARBUSTIVA

VEGETAÇÃO HERBÁCEA 
As fotos são explicadas no decorrer do texto da atividade: quinze anos depois da primeira foto, a faixa de areia está mais estreita, evidenciando a elevação do nível do mar e a sua consequente aproximação da vegetação, além disso, mostra que as formações vegetais (herbácea e arbustiva) encontram-se modificadas: onde antes havia uma vegetação predominantemente arbustiva, após quinze anos passa a apresentar herbáceas com mais frequência (pontos vermelhos). Essas formações vegetais são também ilustradas por meio de fotos, focando suas diferenças.

O aluno, então, é desafiado a dar explicações a respeito da situação ocorrida de forma escrita. Nessa fase, o aluno conta com um texto de apoio que fornece bases teóricas para a resolução das seguintes questões:

3. Por que, com a aproximação do mar, a vegetação herbácea começou a aparecer com mais freqüência onde antes predominava a vegetação arbustiva?

4. Como se deu esse processo?

Nesse texto dá-se ênfase a estruturas adaptativas das plantas herbáceas dessa região. Esperávamos com isso, que os alunos relacionassem as informações do texto descritivo na resolução do problema e que, além disso, desenvolvessem um texto escrito com conteúdo científico.

Na etapa final, a professora foi instruída a mediar uma discussão retomando as ideias prévias dos alunos da atividade 1 , contrastando com as explicações das questões da atividade 2. Podendo, dessa forma, avaliar as respostas dadas ao fim da atividade comparadas à primeira atividade, verificando se ocorreram mudanças de concepções ou então, o quanto as explicações tornaram-se mais completas e com conteúdo científico. Além disso, a discussão teve como objetivo verificar a existência de dúvidas e ainda, discutir a respeito de outros possíveis fatores que poderiam influenciar na dinâmica de um ecossistema e que também poderiam estar ligados à mudança na estrutura da vegetação da restinga. 


\subsection{PREPARAÇÃO DA SEQUÊNCIA DIDÁTICA E APLICAÇÃO}

A preparação é a fase que antecede a aplicação da sequência didática em sala de aula. Há um processo de negociação, ou seja, é o momento em que a professora pode sugerir modificações da sequência didática e adequá-la conforme o contexto da turma. Essa fase é desenvolvida em três fases:

Fase 1. Pesquisador-Mediador: nessa etapa, a pesquisadora descreve e declaro os objetivos e as orientações a serem passadas à professora (APÊNDICE 2) para o mediador.

Fase 2. Mediador-Professor: o mediador, então, declara os objetivos e orientações recomendadas pela pesquisadora. Deixando explícita a autonomia da professora em sala de aula, negociando modificações. Essa fase foi gravada em áudio e vídeo e posteriormente transcrita (APÊNDICE 3).

Fase 3. Mediador-Pesquisador: o mediador negocia com a pesquisadora as sugestões feitas pela professora. No caso desta pesquisa, como não ocorreram dúvidas nem sugestões por parte da professora, essa fase foi descartada.

A aplicação da sequência didática foi realizada em duas aulas de 50 minutos as quais foram gravadas em áudio e vídeo por um sujeito externo à pesquisa. Os alunos, assim como seus pais, foram informados com antecedência sobre a atividade e sobre a filmagem da aula e, dessa forma assinaram um termo de consentimento livre e esclarecido.

A filmagem foi realizada levando em consideração os cuidados discutidos por Carvalho (2004). E, ao fim da atividade o texto escrito pelos alunos (ANEXO 2) e as imagens de vídeo foram recolhidos para análise. 


\subsection{CONSTRUÇÃO DOS DADOS DA PESQUISA}

\subsubsection{Identificação e (re)nomeação dos sujeitos em turnos de fala} transcritos e textos escritos dos alunos

As gravações das aulas foram inicialmente separadas em episódios: 1) referese à primeira atividade, considerando o início da aplicação da SD até o levantamento de hipóteses; 2) episódio 2: refere-se à segunda atividade até à saída para o intervalo de aulas dos alunos; 3 ) tem início com o retorno dos alunos do intervalo ao fim da atividade escrita; 4) refere-se à fase de discussão.

Dessa forma, as gravações das aulas foram transcritas (APÊNDICE 4) dentro das normas propostas por Petri (1999, p.19-20). Para cada episódio enumeramos os turnos de fala e identificamos os sujeitos das falas.

Com o intuito de preservar a identidade da professora e dos alunos, optamos por renomear os sujeitos envolvidos da seguinte maneira: a sigla 'Me' quando a fala partiu do mediador, 'Pr' quando a fala partiu da professora e 'A1, A2, An' quando a fala partiu dos alunos. A numeração foi seguida de acordo com a posição de cada aluno em sala de aula, ou seja, iniciamos a contagem a partir de A1 que se encontrava na primeira carteira e seguindo a ordem de frente para trás, da esquerda para a direita. Da mesma forma, foram identificados os textos escritos pelos alunos.

\subsubsection{Análise Interacional}

Consideramos na análise interacional as relações estabelecidas entre os sujeitos (mediador, professora, alunos) e o texto. Identificamos as atitudes dos sujeitos envolvidos em cada fase, desde a negociação até a aplicação da sequência didática.

Essas atitudes foram identificadas a partir da transcrição dos episódios de fala dos sujeitos de acordo com as seguintes posturas adotadas: 
Quadro 2. Classificação das posturas.

\begin{tabular}{|c|c|}
\hline POSTURA & ATITUDE \\
\hline $\begin{array}{l}\text { Descreve procedimentos e dados da } \\
\text { sequência didática; faz a leitura original do } \\
\text { texto sem reinterpretações. }\end{array}$ & DESCREVE \\
\hline $\begin{array}{l}\text { Explica fenômenos fazendo referência ao } \\
\text { conhecimento científico }\end{array}$ & EXPLICA \\
\hline $\begin{array}{l}\text { Traz algum apoio à explicação, um novo } \\
\text { conceito ou informação que fortalece a } \\
\text { explicação }\end{array}$ & APOIA \\
\hline $\begin{array}{l}\text { Reproduz um conceito ou informação já } \\
\text { mencionada anteriormente ao explicar ou } \\
\text { expor uma ideia }\end{array}$ & REPRODUZ \\
\hline $\begin{array}{l}\text { Conduz o discurso no direcionamento de um } \\
\text { conhecimento }\end{array}$ & ORIENTA \\
\hline $\begin{array}{l}\text { Afirma, aceita uma "ordem" ou uma } \\
\text { explicação sem contestar }\end{array}$ & ACEITA \\
\hline Questiona a veracidade de alguma informação & QUESTIONA \\
\hline $\begin{array}{l}\text { Faz planejamentos tendo em vista ações } \\
\text { futuras }\end{array}$ & PLANEJA \\
\hline $\begin{array}{l}\text { Constrói o conhecimento de forma autônoma } \\
\text { (quando determinada informação não havia } \\
\text { sido citada anteriormente), ou seja, não } \\
\text { reproduz conhecimentos ao explicar ou expor } \\
\text { uma ideia }\end{array}$ & REINTERPRETA \\
\hline
\end{tabular}

A partir dessas atitudes classificamos o comportamento dos sujeitos envolvidos em ativo ou passivo.

Para isso tomamos como base o conceito de responsividade discutido por Bakhtin e seu círculo e ampliado por Menegassi. Nossa reinterpretação acerca do conceito leva em conta que tratar do caráter responsivo das práticas de linguagem implica em pensar no papel fundamental que o outro, isto é, o interlocutor socialmente situado, exerce nos processos de interação verbal (MENEGASSI, 2009). Ou 
seja, sempre que se desenvolve uma enunciação, é esperada por parte do outro uma resposta.

Em um movimento dialógico, a intenção ou atitude do sujeito falante é compreendida pelo seu interlocutor e a partir dessa compreensão adotará atitudes em resposta ao primeiro, e vice-versa.

As atitudes, por sua vez, esboçam determinados comportamentos responsivos que conduzem basicamente à reprodução de conhecimentos (passivo) ou à reinterpretação de conhecimentos (ativo):

Quadro 3. Classificação das atitudes.

\begin{tabular}{cc}
\hline COMPORTAMENTO RESPONSIVO & ATITUDES \\
\hline ATIVO & Explica \\
& Apoia \\
& Orienta \\
& Questiona \\
& Planeja \\
& Reinterpreta \\
PASSIVO & Descreve \\
& Reproduz \\
& Aceita \\
\hline
\end{tabular}

De acordo com as classificações descritas na análise interacional, analisamos as relações entre:

\section{a) MEDIADOR - PROFESSORA - TEXTO (sequência didática/roteiro)}

Na fase da preparação da sequência didática, interagem mediador, professora e texto (FIGURA 1). Nessa fase, o texto (APÊNDICE 2) utilizado é a descrição da sequência didática. Esse texto apresenta instruções ao professor que são negociadas pelo mediador. Diante das interações, classificamos as atitudes e os comportamentos responsivos do mediador e da professora. 


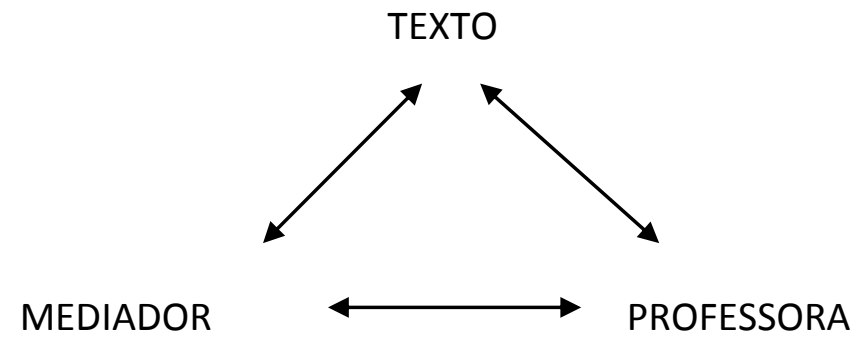

FIGURA 1. Interações na fase da preparação da sequência didática.

\section{b) ALUNOS - PROFESSORA - TEXTO (sequência didática)}

A segunda fase da análise interacional é o momento de aplicação da sequência didática em que participam os alunos, a professora e o texto (FIGURA 2). Assim, classificamos os comportamentos responsivos dos sujeitos nos episódios 2 e 3 os quais possuem relação direta com a produção textual dos alunos.

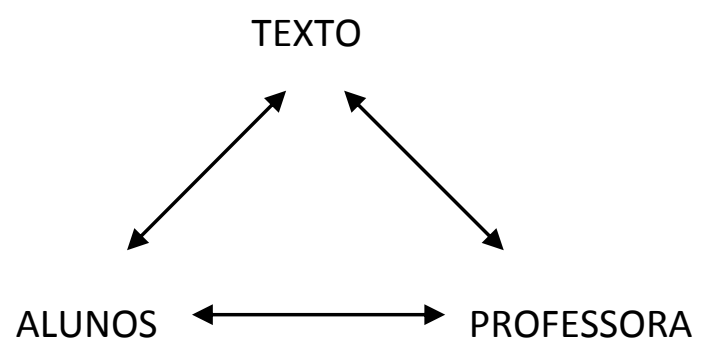

FIGURA 2. Interações na fase da aplicação da sequência didática.

$\mathrm{Na}$ produção textual, identificamos as atitudes de reprodução e/ou reinterpretação de conhecimentos dos alunos (QUADRO 4). 
Quadro 4. Classificação das posturas na produção textual.

\begin{tabular}{lc}
\hline \multicolumn{1}{c}{ POSTURA } & ATITUDE \\
\hline $\begin{array}{l}\text { Reproduz, copia a fala de alguém ou do } \\
\text { texto da sequência didática e/ou do texto } \\
\text { de apoio }\end{array}$ & REPRODUÇÃO DE CONHECIMENTO \\
$\begin{array}{l}\text { Traz elementos externos, que não foram } \\
\text { citados ou discutidos durante a aplicação } \\
\text { da sequência didática }\end{array}$ & REINTERPRETAÇÃO DE CONHECIMENTO \\
\hline
\end{tabular}

Após identificarmos as atitudes dos alunos na elaboração de seus textos, classificamos seus comportamentos responsivos de acordo com o grau de autonomia (QUADRO 5). Ou seja, um comportamento responsivo ativo pode ser autônomo ou de transição:

- Comportamento responsivo ativo autônomo: possui maior grau de autonomia, não se refere a nenhum conhecimento ou ideia já discutida

- Comportamento responsivo ativo de transição: possui certo grau de autonomia, traz ideias novas, porém ainda utiliza reproduções.

- Comportamento responsivo passivo: possui apenas reproduções

Quadro 5. Classificação das atitudes na produção textual.

\begin{tabular}{|c|c|c|}
\hline $\begin{array}{l}\text { COMPORTAMENTO } \\
\text { RESPONSIVO }\end{array}$ & AUTONOMIA & ATITUDE \\
\hline ATIVO $\left\{\begin{array}{l}\text { AUTÔNOMO } \\
\text { TRANSIÇÃO }\end{array}\right.$ & + & $\begin{array}{c}\text { REINTERPRETAÇÃO DE CONHECIMENTO } \\
\text { REINTERPRETAÇÃO E REPRODUÇÃO DE } \\
\text { CONHECIMENTO }\end{array}$ \\
\hline PASSIVO & & REPRODUÇÃO DE CONHECIMENTO \\
\hline
\end{tabular}




\subsubsection{Análise conceitual}

Por fim, os textos escritos foram classificados de acordo com seu conteúdo conceitual: adequado ou não adequado quanto ao conhecimento científico.

A análise conceitual é uma etapa muito importante, pois mesmo que um aluno apresente um comportamento totalmente ativo (autônomo), não quer dizer que ele seja alfabetizado cientificamente (no sentido de conseguir transpor um conhecimento científico de maneira adequada a um dado contexto). 


\section{CAPÍTULO 5. RESULTADOS}

\subsection{MEDIADOR - PROFESSORA - TEXTO (sequência didática/roteiro )}

A seguir apresentamos os resultados provenientes das atitudes do mediador durante a fase de preparação para a aplicação da sequência didática. Nessa fase o mediador e a professora contam com um texto instrucional e descritivo da sequência didática.

Os QUADROS 6 a 10 são recortes dos turnos de fala os quais o mediador faz descrições em todas as fases da sequência didática.

Quadro 6. Mediador faz descrições durante a fase de contextualização da sequência didática.

\begin{tabular}{|c|c|c|c|}
\hline TURNO & SUJEITO & FALA & ATITUDE \\
\hline 11 & ME & $\begin{array}{l}\text { é suas consequências para cidades litorâneas...esse } \\
\text { texto aqui o objetivo dele é aproximar os estudantes } \\
\text { das questões colocadas pela mídia...né da } \\
\text { própria...temática do aquecimento global e as } \\
\text { relações da elevação do nível do mar e a destruição } \\
\text { das cidades...então........seria interessante se você } \\
\text { pudesse ler em voz alta e explicar o texto }\end{array}$ & DESCREVE \\
\hline 12 & PR & Sim & \\
\hline 13 & ME & junto com os alunos & DESCREVE \\
\hline 14 & PR & tá ok & \\
\hline 15 & ME & $\begin{array}{l}\text { o texto é um trecho bem curtinho que é o seguinte } \\
\text { ó... "o avanço do mar...pesquisa da USP revela que o } \\
\text { nível do oceano no Brasil sobe quatro milímetros por } \\
\text { ano...índice é considerado alto e coloca em risco } \\
\text { áreas litorâneas do país...não há dúvida de que o } \\
\text { nível do mar tem aumentado gradativamente no } \\
\text { litoral brasileiro...a conclusão consta de estudo } \\
\text { realizado pelo instituto oceanográfico da } \\
\text { universidade de são paulo io USP....alerta significa que } \\
\text { o país pode sofrer no futuro com uma das piores } \\
\text { conseqüências do aquecimento global a destruição } \\
\text { de regiões inteiras localizadas próximo à costa...as } \\
\text { possíveis conseqüências do fenômeno vão da perda } \\
\text { da faixa de areia à destruição de cidades...passando } \\
\text { por ressacas mais violentas e inúmeros outros } \\
\text { transtornos...Milton Kampel...especialista do instituto } \\
\text { nacional de pesquisas espaciais...inpe...diz que a } \\
\text { elevação do oceano preocupa porque as regiões }\end{array}$ & DESCREVE \\
\hline
\end{tabular}




\begin{tabular}{|c|c|c|c|}
\hline & & $\begin{array}{l}\text { costeiras costumam ter alta densidade } \\
\text { populacional...milhões de pessoas vivem numa faixa } \\
\text { entre um metro e cinco metros da linha da costa" }\end{array}$ & \\
\hline 16 & PR & Ok & \\
\hline 17 & ME & $\begin{array}{l}\text { tudo bem? então esse é o trecho do jornal a ser feita } \\
\text { a leitura em voz alta e após a leitura do } \\
\text { texto...é...é....mostrar...é...ele ressalta a ocupação das } \\
\text { cidades litorâneas nessa faixa e pode ser que surja aí } \\
\text { nesse caso...uma dúvida que é em relação a definição } \\
\text { de restinga }\end{array}$ & DESCREVE \\
\hline 18 & PR & Tá & \\
\hline 19 & ME & $\begin{array}{l}\text { tá? nesse primeiro momento...a idéia aqui pra } \\
\text { proposta é que só diga que é um local } \\
\text { caracteriza...é...a vegetação característica desse } \\
\text { local...tá? não necessitando de maiores detalhes }\end{array}$ & DESCREVE \\
\hline 20 & PR & Certo & \\
\hline 21 & ME & $\begin{array}{l}\text { "e cada vez mais casas e edifícios são construídos ao } \\
\text { longo das planícies litorâneas para abrigar essa } \\
\text { quantidade enorme de pessoas...e } \\
\text { consequentemente, a vegetação ali existente a } \\
\text { restinga é devastada...hoje em dia são poucas as } \\
\text { restingas ainda preservadas em todo o Brasil"..então } \\
\text { a idéia agora é mostrar duas imagens cê tá vendo a } \\
\text { figura um...retinga do estaleiro em Ubatuba e a figura } \\
\text { dois que é a praia de santos...né?santos são } \\
\text { Paulo...então a idéia aqui agora é mostrar aos } \\
\text { estudantes o que que é uma restinga mesmo...né...e } \\
\text { a planície que ela ocupa...então é muito importante } \\
\text { aqui se você puder enfatizar a região que a gente tá } \\
\text { chamando de planície...mostrando pros alunos a } \\
\text { distância entre a linha do mar e do morro tá?e as } \\
\text { diferenças...por exemplo a vegetação nativa } \\
\text { ocupando aqui essa região e na figura }\end{array}$ & DESCREVE \\
\hline
\end{tabular}

Quadro 7. Mediador faz descrições durante a fase de levantamento de hipóteses da sequência didática.

\begin{tabular}{|l|l|l|l|}
\hline 31 & ME & $\begin{array}{l}\text { então o que a gente fez na primeira parte foi fazê } \\
\text { essa relação entre a elevação do nível do mar e } \\
\text { cidades }\end{array}$ & DESCREVE \\
\hline 32 & PR & Tá & $\begin{array}{l}\text { e destacamos a divulgação disso lá no jornal na mídia } \\
\text { ao contrário de elevação do nível do mar e vegetação } \\
\text { que dificilmente a gente se discute } \\
\text { isso...então...é...talvez aí nesse momento fazer um } \\
\text { link dessa idéia...é...entre essa questão da elevação } \\
\text { do nível do mar e a destruição de cidade e o que } \\
\text { possivelmente pode ocorrer numa região onde não }\end{array}$ \\
\hline
\end{tabular}




\begin{tabular}{|c|c|c|c|}
\hline & & tem cidade mas sim uma restinga preservada & \\
\hline 34 & PR & Tá & \\
\hline 35 & ME & $\begin{array}{l}\text { então " vimos no início da atividade que a elevação } \\
\text { do nível do mar está na maioria das vezes associado à } \\
\text { destruição de cidades litorâneas figura três e } \\
\text { constantemente é possível encontrar essas } \\
\text { informações nos jornais na televisão e na } \\
\text { internet"...então a figura três aí mostrando }\end{array}$ & DESCREVE \\
\hline 36 & PR & uma área devastada & \\
\hline 37 & ME & $\begin{array}{l}\text { uma área devastada urbana...tá...então a calçada } \\
\text { sendo atingida aí pela elevação do nível do mar... } \\
\text { "Porém, pouco se fala das consequências da elevação } \\
\text { do nível do mar nas áreas em que a vegetação ainda } \\
\text { é preservada" então daí lança-se a questão } \\
\text { "pense...quais seriam as consequências? Será que a } \\
\text { vegetação existente nessas áreas pode ser afetada } \\
\text { com a aproximação do mar?" entendeu a relação? }\end{array}$ & DESCREVE \\
\hline 38 & PR & Entendi & \\
\hline 39 & ME & $\begin{array}{l}\text { então já que o pólo discutido é a questão das } \\
\text { cidades...a questão levantada é...e quais as } \\
\text { consequências? né...se }\end{array}$ & DESCREVE \\
\hline 40 & PR & levá essa discussão pra uma área natural...preservada & \\
\hline 41 & ME & $\begin{array}{l}\text { isso... a elevação do nível do mar pra vegetação em } \\
\text { áreas que não estão ocupadas pela zona } \\
\text { urbana...tá...só que antes deles pensarem nessa } \\
\text { questão...é importante que a gente leia o quadro } \\
\text { aqui abaixo na sequência que tá escrito } \\
\text { atenção...tá...por que?porque na verdade pode ser } \\
\text { que ocorra de uma...de uma idéia assim de um } \\
\text { tsunami ou uma...carga muito grande de água por } \\
\text { algum fenômeno natural que desapareça de uma vez } \\
\text { só com toda essa vegetação }\end{array}$ & DESCREVE \\
\hline 42 & PR & Tá & \\
\hline 43 & ME & na verdade a idéia é trabalhar o aumento gradativo & DESCREVE \\
\hline 44 & PR & Sim & \\
\hline 45 & ME & tudo bem? & \\
\hline 46 & PR & Tudo & \\
\hline 47 & ME & $\begin{array}{l}\text { então até que o quadro atenção tá escrito o } \\
\text { seguinte... "É claro que se o volume das águas do mar } \\
\text { subisse de uma só vez e cobrisse toda a planície } \\
\text { litorânea...toda Restinga iria por água a baixo e } \\
\text { deixaria de existir mas estamos falando de um } \\
\text { aumento no nível do mar que ocorre aos poucos, } \\
\text { diminuindo a faixa de areia entre a vegetação e o mar } \\
\text { ou seja o mar vai se aproximando da vegetação mas } \\
\text { não chega a cobri-la de uma vez"...então esse é o }\end{array}$ & DESCREVE \\
\hline
\end{tabular}




\begin{tabular}{|l|l|l|l|}
\hline & & contexto do problema colocado tá? & \\
\hline $\mathbf{4 8}$ & $\mathbf{P R}$ & Tá & \\
\hline $\mathbf{4 9}$ & $\mathbf{M E}$ & $\begin{array}{l}\text { ahh...quando ficar bem claro esse problema e o } \\
\text { contexto do qual você tá falando...é interessante que } \\
\text { seja lançada duas possíveis hipóteses para que eles } \\
\text { completem e eles escolham }\end{array}$ & DESCREVE \\
\hline $\mathbf{5 0}$ & $\mathbf{P R}$ & Tá & \\
\hline
\end{tabular}

Quadro 8. Mediador faz descrições durante a fase de observação da sequência didática.

\begin{tabular}{|c|c|c|c|}
\hline 81 & ME & $\begin{array}{l}\text { então na imagem aqui ao lado você tem dois quadros } \\
\text { mostrando exatamente a fisionomia de uma região } \\
\text { arbustiva em baixo e da herbácea em cima... }\end{array}$ & DESCREVE \\
\hline 82 & PR & Ok & \\
\hline 83 & ME & $\begin{array}{l}\text { e importante porque como o mapa é uma } \\
\text { representação você mostrar como é } \\
\text { exatamente...agora veja em baixo o que acontece...a } \\
\text { vegetação arbustiva ela começa a ter algumas } \\
\text { lacunas nessas regiões como você vê na figura }\end{array}$ & DESCREVE \\
\hline 84 & PR & deu pra perceber & \\
\hline 85 & ME & $\begin{array}{l}\text { então... "perceba que antes a vegetação herbácea } \\
\text { predominava na faixa da praia beirando a vegetação } \\
\text { arbustiva...A...com a aproximação do mar em B a } \\
\text { vegetação herbácea começou a adentrar e aparecer } \\
\text { com mais frequência nas regiões onde antes a } \\
\text { vegetação arbustiva era mais concentrada...quer } \\
\text { dizer...a figura B é a mesma figura que mostra quinze } \\
\text { anos depois quando o mar avançou }\end{array}$ & DESCREVE \\
\hline 86 & PR & Certo & \\
\hline
\end{tabular}

Quadro 9. Mediador faz descrições durante a fase explicação da sequência didática.

\begin{tabular}{|l|l|l|l|}
\hline 99 & ME & $\begin{array}{l}\text { "agora, com base no material de apoio } \\
\text { responda...por que, com a aproximação do mar a } \\
\text { vegetação herbácea começou a aparecer com mais } \\
\text { frequência onde antes predominava a vegetação } \\
\text { arbustiva? Como se deu esse processo?" sabe a } \\
\text { imagem mostrando... o avanço? }\end{array}$ & DESCREVE \\
\hline $\mathbf{1 0 0}$ & $\mathbf{P R}$ & $\begin{array}{l}\text { sim...por que um lugar que a gente não tinha uma } \\
\text { vegetação agora a gente tem...né...é isso }\end{array}$ & \\
\hline $\mathbf{1 0 1}$ & $\mathbf{M E}$ & $\begin{array}{l}\text { e...exatamente na imagem que ocorreu o aumento } \\
\text { do nível do mar...você houve...houve uma mudança } \\
\text { na ocupação da vegetação...como ele explica isso?tá? }\end{array}$ & DESCREVE \\
\hline $\mathbf{1 0 2}$ & $\mathbf{P R}$ & Tá & \\
\hline
\end{tabular}




\begin{tabular}{|c|c|c|c|}
\hline 103 & ME & $\begin{array}{l}\text { o texto de apoio que você tem é um texto } \\
\text { descritivo...né...então ele vai usar as informações de } \\
\text { acordo com o que ele achar importante }\end{array}$ & DESCREVE \\
\hline 104 & PR & $\begin{array}{l}\text { e aqui sim...nesse texto vai tá a definição de } \\
\text { restinga...e tudo mais que antes eu não tinha } \\
\text { definido alí no começo... }\end{array}$ & \\
\hline 105 & ME & $\begin{array}{l}\text { exatamente...não define no começo porque agora no } \\
\text { texto ele vai te informações...ele não acha no } \\
\text { texto...e uma coisa que talvez você possa conversar } \\
\text { com eles...um lugar onde ele acha uma resposta... }\end{array}$ & DESCREVE \\
\hline 106 & PR & tá & \\
\hline 107 & ME & $\begin{array}{l}\text { na verdade ele tem que construir um texto } \\
\text { argumentativo...ele vai usar as informações pra } \\
\text { construir o texto dele }\end{array}$ & DESCREVE \\
\hline 108 & PR & sim...ele não vai achar no texto isso & \\
\hline 109 & ME & uma resposta pronta & \\
\hline 110 & PR & tá & \\
\hline
\end{tabular}

Quadro 10. Mediador faz descrições durante a fase de discussão da sequência didática.

\begin{tabular}{|l|l|l|l|}
\hline 111 & ME & $\begin{array}{l}\text { finalizando verifique quantos alunos mudaram de } \\
\text { opinião comparando-se as respostas da atividade um } \\
\text { e dois...lembra as duas hipóteses? }\end{array}$ & DESCREVE \\
\hline $\mathbf{1 1 2}$ & PR & $\begin{array}{l}\text { as perguntas...se alteravam ou não a vegetação } \\
\text { sim...exatamente...ele deu aquela...ele completou fez } \\
\text { aquelas duas hipóteses... "discuta com os alunos } \\
\text { conduzindo a uma explicação mais viável para o } \\
\text { problema é importante que fique claro que essa não } \\
\text { é uma situação verídica e que nem mesmo pode ser } \\
\text { considerada uma resposta definitiva pois existem } \\
\text { outros diversos fatores que podem influenciar na } \\
\text { dinâmica de um ecossistema e que além disso o } \\
\text { problema não partiu de nenhuma pesquisa } \\
\text { científica"...né? assim só elucidar pra eles que é uma } \\
\text { situação...é...que foi construída não é real...não é o } \\
\text { único fator que determina as mudanças de um } \\
\text { ecossistema }\end{array}$ & DESCREVE \\
\hline
\end{tabular}


Questionamentos também foram apontados pelo mediador como é o caso do QUADRO 11 a seguir.

Quadro 11. Questionamento apontado pelo mediador.

\begin{tabular}{|l|l|l|l|}
\hline 168 & ME & $\begin{array}{l}\text { então você espera que como você já trabalhou essa } \\
\text {...essa...adaptação você acha que essa sequência é } \\
\text { adequada ao seu grupo }\end{array}$ & QUESTIONA \\
\hline
\end{tabular}

Encontramos também orientações realizadas pelo mediador no sentido de direcionar o olhar da professora para a mediação com os alunos na elaboração das respostas (QUADRO 12).

\section{Quadro 12. ORIENTA}

\begin{tabular}{|c|c|c|c|}
\hline 131 & ME & $\begin{array}{l}\text { não que você tenha que induzir ou forçar pra que ele } \\
\text { diga isso...você tem que colocar a situação e mediar a } \\
\text { situação }\end{array}$ & ORIENTA \\
\hline 132 & PR & ele que tem que tirar essas conclusões & \\
\hline 133 & ME & $\begin{array}{l}\text { ele que chegue...ô PR mas e se ele chegar em outras } \\
\text { conclusões?são conclusões }\end{array}$ & \\
\hline 134 & PR & $\operatorname{sim}$ & \\
\hline 135 & ME & $\begin{array}{l}\text { ele pode chegar com quais conclusões que ele achar } \\
\text { que deve com base nos dados...caso ele esteje } \\
\text { chegando a conclusões sem fundamentação nos } \\
\text { dados oferecidos aqui o que que você pode fazer é } \\
\text { reforçar os dados...olha...mas qual é a relação da } \\
\text { planta herbácea com o ambiente que ela vive?porque } \\
\text { de repente ele não tá considerando esse dado...mas } \\
\text { isso numa forma de mediar...é ele que tem que } \\
\text { chegar nas conclusões dele }\end{array}$ & ORIENTA \\
\hline
\end{tabular}


A partir da identificação das atitudes, podemos classificar o comportamento do mediador como passivo (QUADRO 13).

Quadro 13. Comportamento responsivo

\begin{tabular}{|l|c|c|}
\hline ATITUDE & OCORRÊNCIAS & COMPORTAMENTO RESPONSIVO \\
\hline Descreve & 54 & Passivo \\
\hline Questiona & 3 & Ativo \\
\hline Orienta & 3 & Ativo \\
\hline
\end{tabular}

Já a professora, na maior parte de suas falas, tem atitude de aceitação (QUADRO 14).

Quadro 14. Atitudes de aceitação da professora.

\begin{tabular}{|c|c|c|c|}
\hline TURNO & SUJEITO & FALA & ATITUDE \\
\hline 11 & ME & $\begin{array}{l}\text { é suas conseqüências para cidades litorâneas...esse } \\
\text { texto aqui o objetivo dele é aproximar os estudantes } \\
\text { das questões colocadas pela mídia...né da } \\
\text { própria...temática do aquecimento global e as } \\
\text { relações da elevação do nível do mar e a destruição } \\
\text { das cidades...então........seria interessante se você } \\
\text { pudesse ler em voz alta e explicar o texto }\end{array}$ & DESCREVE \\
\hline 12 & PR & Sim & ACEITA \\
\hline 13 & ME & junto com os alunos & DESCREVE \\
\hline 14 & PR & tá ok & ACEITA \\
\hline 15 & ME & $\begin{array}{l}\text { o texto é um trecho bem curtinho que é o seguinte } \\
\text { ó... "o avanço do mar...pesquisa da USP revela que o } \\
\text { nível do oceano no Brasil sobe quatro milímetros por } \\
\text { ano...índice é considerado alto e coloca em risco } \\
\text { áreas litorâneas do país...não há dúvida de que o } \\
\text { nível do mar tem aumentado gradativamente no } \\
\text { litoral brasileiro...a conclusão consta de estudo } \\
\text { realizado pelo instituto oceanográfico da } \\
\text { universidade de são paulo io USP...alerta significa que } \\
\text { o país pode sofrer no futuro com uma das piores } \\
\text { conseqüências do aquecimento global a destruição } \\
\text { de regiões inteiras localizadas próximo à costa...as } \\
\text { possíveis conseqüências do fenômeno vão da perda } \\
\text { da faixa de areia à destruição de cidades...passando }\end{array}$ & DESCREVE \\
\hline
\end{tabular}




\begin{tabular}{|c|c|c|c|}
\hline & & $\begin{array}{l}\text { por ressacas mais violentas e inúmeros outros } \\
\text { transtornos...Milton Kampel...especialista do instituto } \\
\text { nacional de pesquisas espaciais...inpe...diz que a } \\
\text { elevação do oceano preocupa porque as regiões } \\
\text { costeiras costumam ter alta densidade } \\
\text { populacional...milhões de pessoas vivem numa faixa } \\
\text { entre um metro e cinco metros da linha da costa" }\end{array}$ & \\
\hline 16 & PR & Ok & \\
\hline 17 & ME & $\begin{array}{l}\text { tudo bem? então esse é o trecho do jornal a ser feita } \\
\text { a leitura em voz alta e após a leitura do } \\
\text { texto...é...é....mostrar...é...ele ressalta a ocupação das } \\
\text { cidades litorâneas nessa faixa e pode ser que surja aí } \\
\text { nesse caso...uma dúvida que é em relação a definição } \\
\text { de restinga }\end{array}$ & DESCREVE \\
\hline 18 & PR & Tá & ACEITA \\
\hline 19 & ME & $\begin{array}{l}\text { tá? nesse primeiro momento...a idéia aqui pra } \\
\text { proposta é que só diga que é um local } \\
\text { caracteriza...é...a vegetação característica desse } \\
\text { local...tá? não necessitando de maiores detalhes }\end{array}$ & DESCREVE \\
\hline 20 & PR & Certo & ACEITA \\
\hline 21 & ME & $\begin{array}{l}\text { “e cada vez mais casas e edifícios são construídos ao } \\
\text { longo das planícies litorâneas para abrigar essa } \\
\text { quantidade enorme de pessoas...e } \\
\text { consequentemente, a vegetação ali existente a } \\
\text { restinga é devastada....hoje em dia são poucas as } \\
\text { restingas ainda preservadas em todo o Brasil”..então } \\
\text { a idéia agora é mostrar duas imagens cê tá vendo a } \\
\text { figura um....retinga do estaleiro em Ubatuba e a figura } \\
\text { dois que é a praia de santos...né?santos são } \\
\text { Paulo...então a idéia aqui agora é mostrar aos } \\
\text { estudantes o que que é uma restinga mesmo...né...e } \\
\text { a planície que ela ocupa...então é muito importante } \\
\text { aqui se você puder enfatizar a região que a gente tá } \\
\text { chamando de planície....mostrando pros alunos a } \\
\text { distância entre a linha do mar e do morro tá?e as } \\
\text { diferenças...por exemplo a vegetação nativa } \\
\text { ocupando aqui essa região e na figura }\end{array}$ & DESCREVE \\
\hline
\end{tabular}

Em alguns momento, a professora também questiona (QUADRO 15) e faz planejamentos relacionados ao tempo da aula (QUADRO 16), ao conteúdo da aula (QUADRO 17) e à previsão de uma mediação em sala de aula (QUADRO 18). 
Quadro 15. Questiona

\begin{tabular}{|l|l|l|l|}
\hline 65 & ME & $\begin{array}{l}\text { que ficou mais estreito quinze anos depois da } \\
\text { aproximação do nível do mar...então a figura A } \\
\text { apresenta a faixa da praia mais estreita que a figura B } \\
\text { caracterizando elevação do nível do mar na região no } \\
\text { decorrer desses 15 anos...tá...tudo bem? }\end{array}$ & DESCREVE \\
\hline 66 & PR & $\begin{array}{l}\text { figura A apresenta a faixa da praia mais estreita que a } \\
\text { figura B?tá trocado não é?a figura B apresenta faixa }\end{array}$ & QUESTIONA \\
\hline 67 & ME & Isso & ACEITA \\
\hline 68 & PR & tem que corrigir né? & QUESTIONA \\
\hline 69 & ME & tem...tá certo...é isso mesmo...Pr & ACEITA \\
\hline
\end{tabular}

Quadro 16. Planeja o tempo da aula

\begin{tabular}{|l|l|l|l|}
\hline 147 & ME & que que cê acha & \\
\hline 148 & PR & $\begin{array}{l}\text { gostei porque vô tê duas aulas e acho que vô precisar } \\
\text { de duas aulas mesmo...acho que...tem muito } \\
\text { conteúdo muita informação pra ser dada em } \\
\text { cinquenta minutos }\end{array}$ & PLANEJA \\
\hline
\end{tabular}

Quadro 17. Planeja o conteúdo da aula

\begin{tabular}{|c|c|c|c|}
\hline 160 & ME & $\begin{array}{l}\text { tem alguma coisa que você modificaria da } \\
\text { sequência...que você daria idéias para....pensando nos } \\
\text { teus alunos? }\end{array}$ & \\
\hline 161 & PR & $\begin{array}{l}\text { não eu acho que...meu trabalho vai ser...eu vô tê que } \\
\text { tê um trabalho de mediadora muito grande...ler com } \\
\text { eles...explicando com calma...porque são assuntos } \\
\text { que eles não...adaptação eles já conhecem agora } \\
\text { essa parte de restinga eles nunca ouviram falar } \\
\text { ainda...não tem conhecimento muito } \\
\text { aprofundado...então eu vô aprofundar nessa parte }\end{array}$ & PLANEJA \\
\hline 162 & ME & entendi & \\
\hline 163 & PR & né porque adaptação eles já aprenderam... & PLANEJA \\
\hline 164 & ME & certo & \\
\hline 165 & PR & $\begin{array}{l}\text { então eles tem o conteúdo de adaptação...eles já } \\
\text { sabem }\end{array}$ & \\
\hline 166 & ME & eles já sabem & \\
\hline 167 & PR & 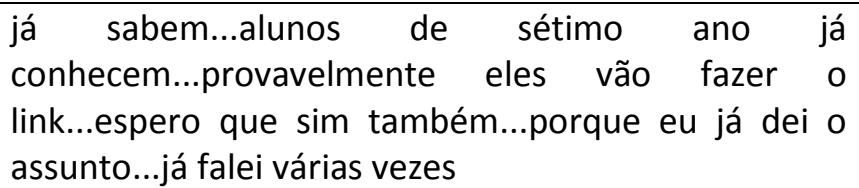 & PLANEJA \\
\hline
\end{tabular}


Quadro 18. Planeja uma possível mediação

\begin{tabular}{|c|c|c|c|}
\hline 170 & ME & $\begin{array}{l}\text { certo...e você...tem alguma dificuldade assim...você } \\
\begin{array}{l}\text { acha que tem alguma dúvida com relação ao } \\
\text { problema } \\
\text { problema...entendimento da situação problema... }\end{array}\end{array}$ & \\
\hline 171 & PR & não & \\
\hline 172 & ME & e da condução da discussão & \\
\hline 173 & PR & $\begin{array}{l}\text { não...de modo algum...eu só vô tê que me restringir a } \\
\text { não extrapolar dessa parte...porque eles vão querer } \\
\text { discutir muito a parte do avanço do mar nas cidades } \\
\text { litorâneas eu acho que eles vão querer ficar falando } \\
\text { ali...e eu tenho que já...é....direcionar a discussão pra } \\
\text { uma área preservada...que é o xis da questão...que a } \\
\text { gente tá tentando analisar o avanço do mar numa } \\
\text { área preservada }\end{array}$ & PLANEJA \\
\hline 174 & ME & $\operatorname{sim}$ & \\
\hline 175 & PR & $\begin{array}{l}\text { e aí como eles vão primeiro ler um texto sobre a área } \\
\text { já ocupada acho que eles vão querer ficar discutindo } \\
\text { muito isso...porque é uma coisa próxima deles...é } \\
\text { uma coisa que realmente tá no noticiário...daí eu vô } \\
\text { te que já conduzir a discussão pra...ó...vamo analisar } \\
\text { agora...numa área não ocupada numa área } \\
\text { preservada...que eles gostam disso...é um assunto } \\
\text { que chama atenção né... }\end{array}$ & PLANEJA \\
\hline 176 & ME & $\begin{array}{l}\text { quer dizer que cê acha que um ponto ali que ce vai te } \\
\text { que ter uma atenção é exatamente naquela transição } \\
\text { onde a gente pega o contexto do ambiente urbano e } \\
\text { tenta fazer o link pra questão preservada }\end{array}$ & QUESTIONA \\
\hline 177 & PR & exato & ACEITA \\
\hline 178 & ME & $\begin{array}{l}\text { então talvez um ponto pra se refletir bastante é } \\
\text { aquelas das imagens onde você tem... }\end{array}$ & \\
\hline 179 & PR & e...vamo olhar agora...vamo mudar...vamo analisar & PLANEJA \\
\hline 180 & ME & $\begin{array}{l}\text { se acontece isso em tal...como é que pode acontecer } \\
\text { em tal lugar }\end{array}$ & \\
\hline 181 & PR & $\begin{array}{l}\text { isso...é isso que nós vamos analisar...porque se não } \\
\text { eles vão ficar querendo conversar...ai porque o } \\
\text { tsunami no Japão é igual porque é o dia a dia...é o } \\
\text { conhecimento que tem na mídia... }\end{array}$ & PLANEJA \\
\hline 182 & ME & $\begin{array}{l}\text { quer dizer...esse é um outro ponto ne...assim...legal } \\
\text { de observar...que antes de você permitir a resposta } \\
\text { das perguntas você faz essa questão e já coloca } \\
\text { aquela....aquele contexto...ó...não é um tsunami...não } \\
\text { é }\end{array}$ & PLANEJA \\
\hline
\end{tabular}

Dessa forma, classificamos o comportamento da professora como passivo por apresentar um maior número de ocorrências de aceitação (QUADRO 19). 
Quadro 19. Comportamento responsivo da professora

\begin{tabular}{|l|c|c|}
\hline ATITUDE & OCORRÊNCIAS & COMPORTAMENTO RESPONSIVO \\
\hline Aceita & 32 & Passivo \\
\hline Questiona & 2 & Ativo \\
\hline Planeja & 12 & Ativo \\
\hline
\end{tabular}

\subsection{ALUNOS - PROFESSORA - TEXTO (sequência didática)}

Os resultados aqui apresentados referem-se às interações estabelecidas durante a aplicação da sequência didática em sala de aula.

A professora utiliza descrições (QUADRO 20) da sequência didática , fazendo uso de falas bastante longas de leitura do texto (QUADRO 21).

Quadro 20. Professora utiliza descrições

\begin{tabular}{|c|c|c|c|}
\hline 54 & Pr & $\begin{array}{l}\text { isso...diminuiu a espessura de areia...não diminuiu?depois } \\
\text { de quinze anos?vamo vê em relação a vegetação...dá uma } \\
\text { olhadinha...tá vendo essas bolinhas vermelhas? }\end{array}$ & DESCREVE \\
\hline 55 & As & sim & \\
\hline 56 & $\mathrm{Pr}$ & $\begin{array}{l}\text { pontilhadas?dá uma olhadinha do lado tem uma legenda né } \\
\text { a vegetação herbácea...e essa parte que tem esse quadrado } \\
\text { branco aqui na vegetação é a vegetação... }\end{array}$ & DESCREVE \\
\hline 57 & As & arbustiva & \\
\hline 58 & $\mathrm{Pr}$ & $\begin{array}{l}\text { arbustiva...dá uma olhada...aqui tem duas fotos pra vocês } \\
\text { terem um idéia de como que é a vegetação é...herbácea e } \\
\text { como que é a vegetação arbustiva...a vegetação herbácea é } \\
\text { mais rasteira...menor...tá vendo?e a arbustiva um pouco } \\
\text { maior...tá vendo isso?consegue...enxergar?ótimo...depois de } \\
\text { quinze anos...olha o que aconteceu com a vegetação?o } \\
\text { pontilhado ele tá o que? }\end{array}$ & DESCREVE \\
\hline
\end{tabular}


Quadro 21. Leitura do texto pela professora.

\begin{tabular}{|c|c|c|c|}
\hline 83 & Pr & $\begin{array}{l}\text { e a disponibilidade de nutrientes também e fatores físicos } \\
\text { como " o movimento da areia... o vento... o atrito do grão } \\
\text { de areia... o vento forte... a influência do sol... a } \\
\text { temperatura... a disponibilidade de água... a } \\
\text { disponibilidade de sal... a salinidade e outros... certo?então } \\
\text { tudo isso vai interferir o que?nas características da } \\
\text { vegetação que a gente tem mais próximo do mar e que nós } \\
\text { temos mais afastadas do mar... deu pra entender? }\end{array}$ & DESCREVE \\
\hline 84 & As & deu & \\
\hline 85 & $\operatorname{Pr}$ & $\begin{array}{l}\text { ótimo... então vamo lá... agora nós vamos fazer uma } \\
\text { viagem... descendo do mar até chegar na planície... vamo } \\
\text { vê... ó... "vamos imaginar que acabamos de desembarcar } \\
\text { em uma praia e seguimos em frente em direção a } \\
\text { encosta... das montanhas como indica a seta abaixo"... tá } \\
\text { vendo? cê acabou de descer lá na praia... cê vai chegar lá } \\
\text { na montanha... ó... ce vai percorrer esse caminho... vamo } \\
\text { vê passo a passo como que é a vegetação... de quando a } \\
\text { gente sai daqui do mar até chegar na encosta... é isso que } \\
\text { nós vamos ver agora... certo? vamo lá... "saindo do mar... } \\
\text { há alguns passos sobre a areia e fora da ação da... das } \\
\text { marés nos deparamos com uma vegetação rasteira... que } \\
\text { chega a aproximadamente quarenta centímetros de altura } \\
\text { sobre o chão... são tufos de capim e plan... e plantas de } \\
\text { ramos muito finos e moles que crescem e se reproduzem } \\
\text { rapidamente...essa é a vegetação herbácea"... então essa } \\
\text { vegetação é aquela vegetação que nós vimos lá no } \\
\text { problema... lembra? tava pontilhada de vermelha... é a } \\
\text { primeira vegetação ao sairmos da praia... mais próximo do } \\
\text { mar... deu pra ver? localizaram ela?... certo? então ela é o } \\
\text { que? baixinha... rasteira né... não cresce muito... vamo virá } \\
\text { a página aqui... alá... a vegetação herbácea é essa } \\
\text { vegetação... que tá marcada pontilhada de vermelha lá na } \\
\text { figura... ela " possui raízes bastante profundas e sistemas } \\
\text { de raízes e rizomas que fixam as plantas na areia e as } \\
\text { mantém mais estáveis, já que a areia da praia se } \\
\text { movimenta com mais facilidade devido ao vento... então } \\
\text { cê tá vendo que essa planta tem o que? as adaptações } \\
\text { corretas pra poder viver ali... porque se elas estão mais } \\
\text { próximas da areia... mais próximas do mar... é importante } \\
\text { que ela tenha o que? uma fixação melhor não é?por que? } \\
\text { o vento bate a areia move... movimenta... tá vendo que }\end{array}$ & DESCREVE \\
\hline
\end{tabular}




\begin{tabular}{|l|l|l|}
\hline & $\begin{array}{l}\text { elas tem as características certinho que permite elas viver } \\
\text { naquela... naquele lugar?vamo lá... "esse tipo de planta é } \\
\text { de grande importância nesse ambiente... pois a areia fica } \\
\text { aderida em suas coroas”... ó...coroa tá marcado aí na } \\
\text { setinha ao lado... tá vendo?... os tufinho?...é no } \\
\text { “emaranhado de suas raízes que dificulta que o vento } \\
\text { carregue grandes quantidades dessa areia em direção ao } \\
\text { interior"... então a areia bate na coroa e... fica... tá... fica } \\
\text { presa... }\end{array}$ \\
\hline
\end{tabular}

\section{Quadro 22. Explica}

\begin{tabular}{|l|l|l|l|}
\hline 85 & Pr & $\begin{array}{l}\text {..então cê tá vendo que essa planta tem o que? as } \\
\text { adaptações corretas pra poder viver ali... porque se elas } \\
\text { estão mais próximas da areia... mais próximas do mar... é } \\
\text { importante que ela tenha o que? uma fixação melhor não } \\
\end{array}$ & $\begin{array}{l}\text { é?por que? o vento bate a areia move... movimenta... tá } \\
\text { vendo que elas tem as características certinho que permite } \\
\text { elas viver naquela... naquele lugar? ... }\end{array}$ \\
& & \\
\end{tabular}

Algumas orientações foram realizadas pela professora, em um primeiro momento, no sentido de direcionar o olhar do aluno durante a atividade (QUADRO 23); em um segundo momento, no sentido de orientar dúvidas dos alunos (QUADRO 24).

Quadro 23. Orientação da professora direcionando olhar do aluno.

\begin{tabular}{|l|l|l|l|}
\hline $\mathbf{1 9}$ & $\mathbf{P r}$ & $\begin{array}{l}\text { não tá?bem espessa não tá?tem o mar a praia e embaixo } \\
\text { da praia a vegetação...tá bem branca essa faixa não tá? }\end{array}$ & DESCREVE \\
\hline $\mathbf{2 0}$ & $\mathbf{A 3}$ & a vegetação é maior & \\
\hline $\mathbf{2 1}$ & $\mathbf{P r}$ & a vegetação?e a areia?que que cê acha da areia? & ORIENTA \\
\hline
\end{tabular}


Quadro 24. Orientação da professora diante de dúvidas do aluno.

\begin{tabular}{|c|c|c|c|}
\hline 136 & A3 & não tô conseguindo & \\
\hline 137 & $\operatorname{Pr}$ & $\begin{array}{l}\text { não tá conseguindo... vamo lá... o que a gente tinha } \\
\text { antes?a gente tinha uma faixa de areia muito... }\end{array}$ & ORIENTA \\
\hline 138 & A3 & grande & \\
\hline 139 & $\operatorname{Pr}$ & E aí o mar veio se aproximando e a faixa de areia ficou... & ORIENTA \\
\hline 140 & A3 & menor & \\
\hline 141 & $\operatorname{Pr}$ & menor... é ou não é? & \\
\hline 142 & A3 & é & \\
\hline 143 & $\operatorname{Pr}$ & $\begin{array}{l}\text { diminuiu a areia e o que aconteceu com a vegetação... } \\
\text { quando a areia era espessa... grande aqui a vegetação } \\
\text { arbustiva ficava localizada aqui não é? bem próximo do } \\
\text { mar... não é?e a vegetação arbustiva tomava esse espaço } \\
\text { aqui certo?quando a diminuição da areia diminuiu... só um } \\
\text { minutinho ((outro aluno chama a professora)) com a } \\
\text { diminuição da faixa de areia diminuiu o que aconteceu } \\
\text { com a vegetação arbustiva?ela começou a se... espalhar e } \\
\text { a vegetação arbustiva? }\end{array}$ & ORIENTA \\
\hline 144 & A3 & dominou tudo & \\
\hline 145 & $\operatorname{Pr}$ & $\begin{array}{l}\text { a vegeta... essa é a herbácea... não... essa vegetação } \\
\text { herbácea começou predominar tudo... e a vegetação } \\
\text { arbustiva?cade ela? }\end{array}$ & ORIENTA \\
\hline 146 & A3 & ela sumiu & \\
\hline 147 & $\operatorname{Pr}$ & sumiu... pra onde ela foi? & ORIENTA \\
\hline 148 & A1 & foi embora & \\
\hline 149 & $\operatorname{Pr}$ & ela já não existe mais onde ela... & \\
\hline 150 & A3 & existia & \\
\hline 151 & $\operatorname{Pr}$ & existia & \\
\hline 152 & A2 & ela foi existir em outro lugar... não é & \\
\hline 153 & $\operatorname{Pr}$ & $\begin{array}{l}\text { por que com a aproximação do mar essa vegetação } \\
\text { começou a ( ) o que propiciou essa aproximação do mar... } \\
\text { que características que propiciou... é... esse avanço aqui do } \\
\text { mar propiciou o que?pra essas vegetação aqui deu } \\
\text { condições o que pra essa vegetação herbácea podê... é... } \\
\text { se }\end{array}$ & ORIENTA \\
\hline 154 & A1 & espalhar & \\
\hline 155 & $\operatorname{Pr}$ & $\begin{array}{l}\text { expandir... isso... que que ela fez com a vegetação } \\
\text { arbustiva? }\end{array}$ & ORIENTA \\
\hline 156 & A2 & destruiu? & \\
\hline
\end{tabular}




\begin{tabular}{|l|l|l|l|}
\hline 157 & Pr & quais são as carac & \\
\hline 158 & A3 & que... é... o mar... fez... não & \\
\hline 159 & Pr & $\begin{array}{l}\text { ó... é... por que que a vegetação herbácea depois que } \\
\text { aproximou mais do mar ele conseguiu o que?ela conseguiu } \\
\text { se espalhar?quais são as características das... da... quais } \\
\text { são as características de uma planta herbácea? }\end{array}$ & ORIENTA \\
\hline 160 & A3 & $\begin{array}{l}\text { raízes fortes } \\
\text { isso... aí ela consegue viver melhor... não consegue?tá mais } \\
\text { próximo do mar... e a região... e a vegetação arbustiva? }\end{array}$ & ORIENTA \\
\hline 161 & Pr & ela não consegue & ORIENTA \\
\hline 162 & A3 & pr que que ela não consegue? & \\
\hline 163 & Pr & &
\end{tabular}

Reproduções também foram encontradas em um momento em que um aluno reinterpreta uma informação e a professora passa a utilizar o mesmo significado (QUADRO 25).

\section{Quadro 25. Reproduz}

\begin{tabular}{|c|c|c|c|}
\hline 58 & $\operatorname{Pr}$ & $\begin{array}{l}\text { arbustiva...dá uma olhada...aqui tem duas fotos pra } \\
\text { vocês terem um idéia de como que é a vegetação } \\
\text { é...herbácea e como que é a vegetação arbustiva...a } \\
\text { vegetação herbácea é mais rasteira....menor...tá } \\
\text { vendo?e a arbustiva um pouco maior...tá vendo } \\
\text { isso?consegue...enxergar?ótimo...depois de quinze } \\
\text { anos...olha o que aconteceu com a vegetação?o } \\
\text { pontilhado ele tá o que? }\end{array}$ & \\
\hline 59 & A13 & invadindo a vegetação....arbustiva & REINTERPRETA \\
\hline 60 & $\operatorname{Pr}$ & $\begin{array}{l}\text { perfeito...muito bem...cê tá vendo que essa pontilhada } \\
\text { ele tá...invadindo a vegetação... }\end{array}$ & REPRODUZ \\
\hline 61 & As & arbustiva & \\
\hline 62 & $\operatorname{Pr}$ & $\begin{array}{l}\text { né...então a gente viu que com a diminuição da } \\
\text { espessura de areia a vegetação tá se modificando não } \\
\text { tá?onde a gente tinha uma vegetação herbácea depois } \\
\text { arbustiva a gente agora vê uma vegetação herbácea } \\
\text { invadindo a... }\end{array}$ & REPRODUZ \\
\hline 63 & As & arbustiva & \\
\hline
\end{tabular}




\subsection{TEXTO DOS ALUNOS}

Os resultados obtidos na tabela 1 nos mostram que na maioria dos casos, a atitude do aluno é de reproduzir a fala da professora. Em segundo lugar temos $26,93 \%$ de ocorrências cujas respostas não apresentaram reproduções evidentes do discurso da professora nem do texto. Em terceiro lugar, $23,08 \%$ de ocorrências de alunos que reproduziram cópias do texto em suas respostas e, por fim, apenas 3,84\% que corresponde a uma única ocorrência em que aluno apresentou tanto reproduções da fala da professora como do texto.

Tabela 1: Resultados obtidos a partir da análise das marcas da interação em respostas dos alunos.

\begin{tabular}{|c|c|c|c|}
\hline ATITUDE & Sujeitos & $\begin{array}{l}\text { Quantidade de } \\
\text { ocorrências }\end{array}$ & $\begin{array}{c}\text { Porcentagem } \\
\text { correspondente } \\
\text { (\%) }\end{array}$ \\
\hline $\begin{array}{l}\text { REPRODUÇÃO } \\
\text { PROFESSORA }\end{array}$ & $\begin{array}{c}1,2,4,9,11,13,14 \\
16,18,19,20,21\end{array}$ & 12 & 46,15 \\
\hline $\begin{array}{c}\text { REPRODUÇÃO } \\
\text { TEXTO }\end{array}$ & $7,15,24,10,17,22$ & 6 & 23,08 \\
\hline $\begin{array}{l}\text { REPRODUÇÃO } \\
\text { PROFESSORA E } \\
\text { TEXTO }\end{array}$ & 3 & 1 & 3,84 \\
\hline REINTERPRETAÇÃO & $\begin{array}{c}5,6,8,12,23,25 \\
26\end{array}$ & 7 & 26,93 \\
\hline
\end{tabular}

Podemos observar a partir da tabela 2 que houve uma grande diferença no conteúdo conceitual das respostas escritas pelos alunos: 73,08\% não apresentaram conteúdo científico e apenas $26,92 \%$ dos alunos apresentaram conteúdo científico em suas respostas.

Analisando o conteúdo científico de acordo com as interações estabelecidas, pudemos observar que todos aqueles que apresentaram reproduções do professor nas respostas $(42,31 \%)$ não apresentaram conhecimento científico; daqueles que apresentaram reproduções do texto da atividade $(23,08 \%)$ metade apresentou 
conhecimento científico (11,54\%) e a outra metade não (11,54\%); A única ocorrência de ambas as reproduções (texto e professora) apresentou conhecimento científico, representando 3, 84\%; e por fim, aqueles que reinterpretaram 19,23\% não apresentou conhecimento científico e $7,7 \%$ apresentou conhecimento científico em suas respostas.

Tabela 2: Resultados obtidos a partir da análise do conteúdo conceitual.

\begin{tabular}{|c|c|c|c|c|}
\hline ATITUDE & $\begin{array}{c}\text { Conhecimento } \\
\text { científico } \\
\text { (sujeitos) }\end{array}$ & $\begin{array}{c}\text { Sem } \\
\text { conhecimento } \\
\text { científico } \\
\text { (sujeitos) }\end{array}$ & $\begin{array}{c}\text { Porcentagem } \\
\text { correspondente } \\
\text { Conhecimento } \\
\text { científico (\%) }\end{array}$ & $\begin{array}{c}\text { Porcentagem } \\
\text { correspondente } \\
\text { Sem } \\
\text { conhecimento } \\
\text { científico (\%) }\end{array}$ \\
\hline $\begin{array}{c}\text { REPRODUÇÃO DA } \\
\text { PROFESSORA }\end{array}$ & 13 & $\begin{array}{c}1,2,4,9,11,14,16, \\
18,19,20,21\end{array}$ & 3,84 & 42,31 \\
\hline $\begin{array}{c}\text { REPRODUÇÃO DO } \\
\text { TEXTO }\end{array}$ & $10,17,22$ & $7,15,24$ & 11,54 & 11,54 \\
\hline $\begin{array}{c}\text { REPRODUÇÃO DA } \\
\text { PROFESSORA E } \\
\text { TEXTO }\end{array}$ & 3 & $8,12,23,25,26$ & 7,7 & 19,23 \\
\hline REINTERPRETAÇÃO & 5,6 & $-1,84$ & & \\
\hline
\end{tabular}

Dessa forma, organizamos as atitudes dos alunos conforme as seguintes combinações (FIGURA 3), sendo que o valor numérico apresentado na última coluna (T) representa o número total de ocorrências: 
ATITUDE

REPRODUÇÃO DE

(do professor)

\section{CONHECIMENTO}

CIENTÍFICO

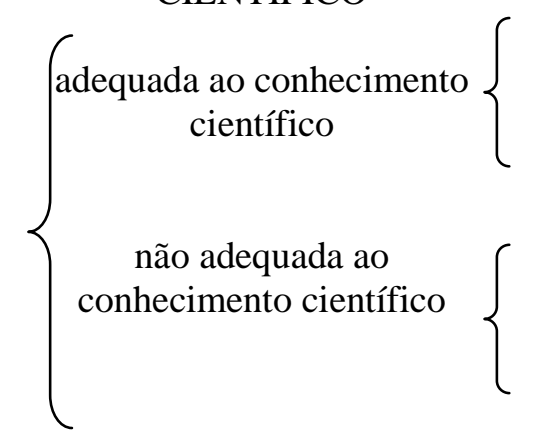

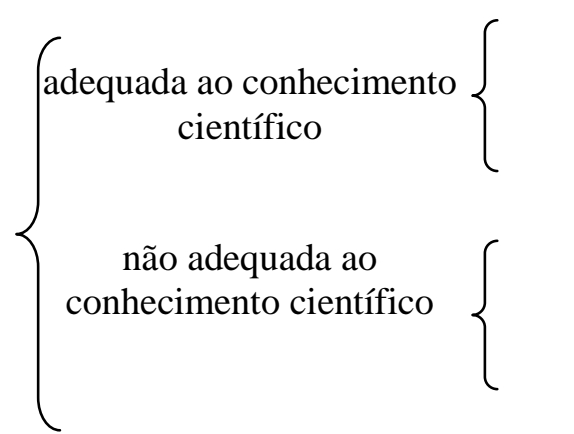

transição passivo

transição passivo
$\mathbf{T}$

1

0

9

2

3

0

1

2

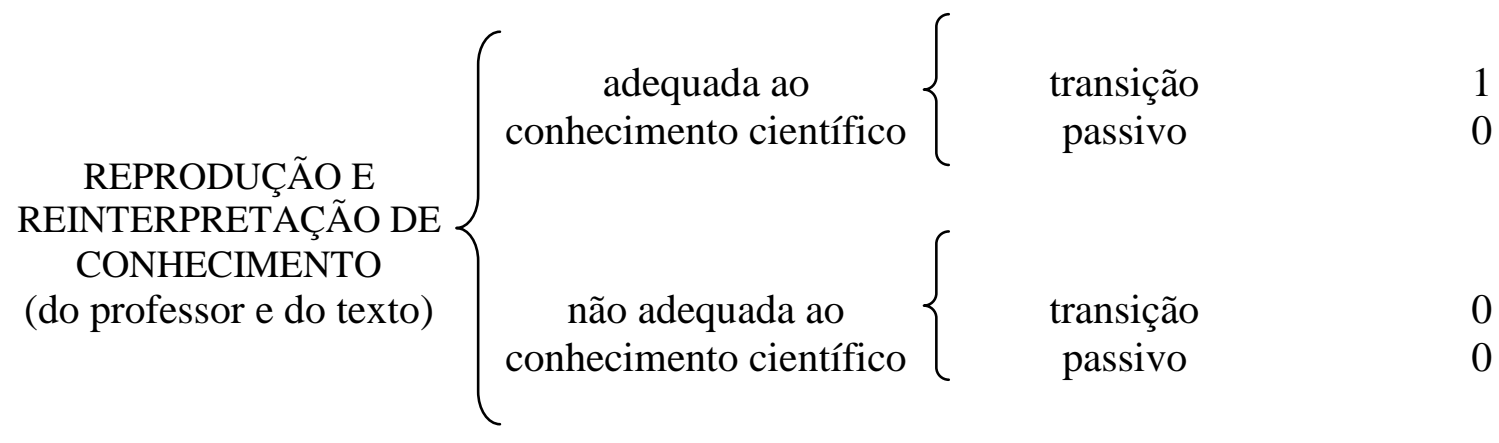

1

0

0

0

2

5

FIGURA 3. Resultados das Interações - Atividade 2. 


\section{CAPÍTULO 6. DISCUSSÃO}

A discussão foi subdividida da seguinte forma: 1) sobre o comportamento responsivo da professora na pré-aplicação e durante a aplicação da sequência didática; 2) sobre as reproduções dos alunos; 3) sobre as reinterpretações dos alunos e; 4) uma síntese dos itens anteriores.

\subsection{PROFESSORA}

De acordo com os resultados, tanto o mediador quanto a professora apresentaram comportamentos passivos durante a negociação da sequência didática.

Um dos motivos para esse caráter passivo provavelmente se deve ao fato das orientações apresentadas nos roteiros (ANEXO) apresentarem um caráter instrucional, apesar da abertura que se dá à professora de modificar e adequar a sequência didática conforme contexto em sala de aula (Ex. 1).

Exemplo 1. Roteiro do Professor. Sequência Didática aberta a adequações.

\section{Roteiro do professor}

Cabe ao professor aplicar a sequência didática em sala de aula conforme instruções do mediador. Informar ao mediador sobre adequações as quais achar conveniente para o contexto de cada sala de aula. Porém, é importante que as adequações não interfiram no objetivo da sequencia didática. Durante a aplicação da sequencia, o professor se orientará pelos passos descritos abaixo, porém é importante que tenha em mente sua total autonomia durante a aula, não se limitando à leitura da atividade, mas interagindo com os alunos da maneira como achar conveniente

O caráter instrucional pode ser observado pelo modo imperativo em que as orientações são passadas (Ex.2): 
Exemplo 2. Orientações da Sequência Didática

\section{Entregue aos alunos somente a atividade 1...}

Leia o texto em voz alta e explique se necessário.

Explique aos alunos que as hipóteses levantadas da atividade anterior serão discutidas...

Dessa forma, o texto é caracterizado pela autoridade, dificultando as modificações que a professora poderia fazer.

Consequentemente, a postura passiva adotada pela professora possivelmente, refletiu na mediação em sala de aula. Podemos observar isso pelos turnos predominantemente descritivos da professora e pelas falas bastante longas caracterizadas pela leitura da atividade durante a aplicação da sequência didática.

Ficou evidente que a proposta de uma postura ativa para a professora ( e para o mediador) não se limitou a adequações ou modificações que esta poderia sugerir. Por mais que a professora se posicionasse, sua compreensão das relações sociais das quais estava submetida influenciou no seu comportamento responsivo.

Percebe-se, assim, que não se trata apenas de responder ao que foi dito pelo locutor, mas de compreender que a formulação de um enunciado endereçado ao outro constitui, por si, uma possível resposta a outros enunciados que circulam na sociedade (BAKHTIN, 2006).

Assim, os sujeitos compreendem cada contexto e se comportam de acordo com as práticas sociais das quais tomam parte ao longo de suas existências. De acordo com Bakhtin/Volochinov

A situação e o auditório obrigam o discurso interior a realizar-se em uma expressão exterior definida, que se insere diretamente no contexto não verbalizado da vida corrente, e nele se amplia pela ação, pelo gesto ou pela resposta verbal dos outros participantes na situação de enunciação. (2006, p.125).

Sendo assim, no caso específico desta pesquisa, o fato da sequência didática ter sido formulada para fins já determinados, e consequentemente ter gerado 
expectativas de resultados, pode ter influenciado no comportamento responsivo da professora.

\subsection{REPRODUÇÕES DOS ALUNOS}

Analisando os resultados da produção escrita, vimos que a maioria dos alunos expressou em suas respostas reproduções da professora trazendo-as em seus textos escritos. Porém, se atentarmos para a qualidade das respostas nenhuma das explicações foi adequada quanto ao conhecimento científico, ou seja, as explicações apresentaram erros conceituais marcados no discurso da professora e que de alguma forma influenciaram no desenvolvimento das explicações dos alunos.

Por exemplo, o uso termo "invadiu" (Ex.1), pela professora foi marcado em vários turnos: no Episódio 2, os turnos 60, 62, 65, 101 (duas vezes), 105 (duas vezes), 107 (duas vezes), 113 (quatro vezes), 125, 135, 171; no episódio 3, os turnos 07, 11 (duas vezes), 17, 22, 26, 30 (duas vezes) e 34. Esse termo ocorreu em 67\% das respostas dos alunos (entre aquelas que apresentaram interação $A-P$ ) dando a ideia de que a vegetação herbácea invadiu o território da vegetação arbustiva, destruindo-a (Ex.2).

Exemplo 1. Episódio 2: Turnos de fala 60, 62 e 113 em que professora usa o termo "invadiu".

Turno 60. perfeito... muito bem... cê tá vendo que essa pontilhada ele tá invadindo a vegetação...

Turno 62. ...então a gente viu que com a diminuição da espessura de areia a vegetação herbácea depois arbustiva a gente vê uma vegetação herbácea invadindo a...

Turno 113 ... aqui existia uma vegetação herbácea... não tinha?que agora depois do avanço do mar a gente viu que ela começou a invadir o lugar da outra 
vegetação... a arbustiva... não é?a gente quer saber o por que ela conseguiu invadir... se ela conseguiu invadir... como ela conseguiu?por que que ela conseguiu invadir? que que ela fez?que que aconteceu com a vegetação arbustiva...

Exemplo 2. Explicações dos alunos com o uso do termo invadir

Com as raízes fortes as plantas herbáceas começam a invadir, porque as plantas arbustiva não são fortes e as plantas herbácea invadem muito facio (A1)

Porque com o avamço do mar elas não tem área, para ficar e com isso elas acabam invadindo a área onde predominava a vegetação arbustiva (A11).

A vegetação herbácea e muito pequena e a arbustiva e muito grande então o herbacia conseguil invadir (A20).

As reproduções do texto também foram bastante comuns. As que apresentaram conhecimento científico (Ex.3) foram todas extraídas de um mesmo trecho do texto de apoio (Ex. 4).

Exemplo 3. Resposta de A17

Porque com a força da água que atinge a praia é possível que uma abertura se forme que possibilita a adentração da vegetação herbácea no território da arbustiva e isso só ocorre graças as características da vegetação arbustiva que faz com que ela não consiga viver nas proximidades da água diferente da herbácea que tem raízes profundas, rizoma e coroa que possibilita a sobrevivência dela nesses locais.

Exemplo 4. Trecho do texto do material de apoio

A vegetação herbácea possui raízes bastante profundas e sistemas de raízes e rizomas que fixam as plantas na areia e as mantém mais estáveis, já que a areia da praia se movimenta com muita facilidade devido ao vento.

Isso pode ter acontecido pelo fato da professora ter reforçado essas características no decorrer da leitura do texto de apoio. Ao falar sobre as 
características da vegetação arbustiva, ela faz uma comparação com a vegetação herbácea retomando justamente as características das raízes e rizoma (Ex.5).

Exemplo 5. Episódio 2. Turno 95. Fala da professora retomando característica da vegetação herbácea.

Turno 95. ... é mais densa (vegetação arbustiva)... ou seja... mais fechada... certo? vamo dá uma estudada nela... essas plantas recebem menor influência do mar... ou seja do sal... da salinidade e dos ventos... o terreno ele é mais estável... lembra que lá era areia? e que as plantas tinha que ter raizes fortes e rizomas pra elas poderem ficar fixas lá... aqui não... aqui o solo ele já é mais estável e as condições de fixação das raízes das plantas melhoram... né elas conseguem ficar mais fixas...

Já aquelas que não se adequaram ao conhecimento científico trazem marcas do texto como cópias, porém as cópias não apresentam relação com a pergunta e a resposta dada (Ex.6), aparentemente, os alunos extraíram trechos do texto de apoio aleatoriamente utilizando-as como resposta.

Exemplo 6. Cópia de trecho do texto como resposta à pergunta

Após a vegetação herbácea, as plantas começam a ficar mais altas e andar, entre elas começa a ficar difícil pois a vegetação é muito mais densa: é a vegetação arbustiva, que pode chegar a 3 metros de altura. (A24)

Um caso particular foi a interação estabelecida entre aluno, professor e texto: o aluno apresentou dificuldades no entendimento da questão e que a princípio achou que bastava copiar alguma parte do texto como resposta (QUADRO 26). Diante disso, a professora orientou o desenvolvimento de A3 tirando suas dúvidas e guiando seu raciocínio. Essa postura da professora refletiu na explicação do aluno, trazendo marcas da sua voz e também do texto dando suporte a sua resposta (Ex. 7). 
Quadro 26: Episódio 3. Turnos de fala da professora e A3.

\begin{tabular}{|c|c|c|}
\hline Turno & Sujeito & Fala \\
\hline 31 & Professora & $\begin{array}{l}\text { ó...a gente sabe que a aproximação do mar fez com que a } \\
\text { vegetação herbácea invadisse o lugar da arbustiva...é ou não } \\
\text { é?como que ela conseguiu invadir? }\end{array}$ \\
\hline \multirow[t]{2}{*}{32} & A3 & onde tá escrito? \\
\hline & Professora & $\begin{array}{l}\text { não não tá escrito...você tem que formular...ce tem que } \\
\text { resolver o problema...né...e aqui você tem o material de } \\
\text { apoio...pra apoiar você a responder...gente ((se volta para a sala } \\
\text { toda)) vocês não vão achar uma resposta pronta no } \\
\text { texto....né...vocês vão ter que contruir...né...resolver o } \\
\text { problema...vocês vão construir sua resposta com a ajuda do } \\
\text { texto certo? }\end{array}$ \\
\hline 33 & A3 & ( ) \\
\hline 34 & Professora & $\begin{array}{l}\text { ó...a gente sabe que a vegetação herbácea... ó...com a } \\
\text { espessura bem próxima do mar ela ficava aqui não } \\
\text { ficava?quando essa espessura diminuiu o mar se aproximou e } \\
\text { ela conseguiu invadir e tomar o lugar da vegetação } \\
\text { arbustiva...que característica tem uma planta herbácea?que } \\
\text { cara... }\end{array}$ \\
\hline 35 & A3 & ela tem as raízes... \\
\hline 36 & Professora & isso...tem as raízes o que? \\
\hline 37 & A3 & Fortes \\
\hline 38 & Professora & $\begin{array}{l}\text { que pode fixar...não é? que características tem as plantas } \\
\text { arbustivas uma planta arbustiva com as características que ela } \\
\text { tem ela consegue sobreviver num lugar mais próximo do mar? e } \\
\text { a planta herbácea...ela é mais apropriada...ela consegue? tenta } \\
\text { resolver o problema nesse sentido }\end{array}$ \\
\hline
\end{tabular}


Exemplo 7. Resposta de A3

Porque o nível da água do mar subiu e deu mais sobrevivência para a vegetação herbácea

Porque a herbácea foi mais apropriada para viver em lugar próximo ao mar por ter as raízes bastante profundas e o sistema das raízes é um rizoma e que fixa as plantas na areia e mantém as herbáceas mais estáveis.

Apesar da maioria dos alunos terem feito reproduções de falas ou de texto, essa maioria esboçou um comportamento de transição. Ou seja, na construção de suas explicações foi realizada uma releitura do que já havia sido dito ou escrito.

Segundo Vygotsky (1991) precisamos de um tempo para ampliarmos os conhecimentos apreendidos socialmente, pois a transformação de um processo intrapessoal num processo interpessoal é resultado de uma longa série de eventos ocorridos ao longo do desenvolvimento. Assim, é relevante considerar o espaço temporal ao pensarmos na prática da escrita, uma vez que

\begin{abstract}
A linguagem escrita demanda, em relação à linguagem oral, um trabalho intelectual mais elaborado. Trata-se de uma linguagem com maior grau de descontextualização na medida em que exige a dupla abstração dos componentes fásicos da linguagem (seu aspecto sonoro externo, por exemplo) e, fundamentalmente, demanda uma abstração em relação ao interlocutor, ausente. (BAQUERO, 2001, p.84)
\end{abstract}

\title{
6.3. REINTERPRETAÇÕES
}

Por fim, grande parte dos alunos não apresentou marcas evidentes da interação em suas repostas. A princípio isso poderia ser interpretado como uma atitude de maior autonomia no desenvolvimento das respostas, ou seja, sem que esses alunos precisassem de qualquer suporte (a voz da professora ou o texto da atividade) para sustentar seu ponto de vista. Porém, a análise do conteúdo conceitual das respostas nos mostra que a maioria não se adequou ao conhecimento científico, por exemplo, nas respostas de A8 e A23 (Ex.8). 
Exemplo 8. Respostas de A8 e A23

Porque o mar tomou tudo e destruiu a vegetação arbustiva. Porque a planta herbácea com o mar ela foi expalhando pela vegetação arbustiva e a planta arbustiva está morrendo por conta da água (A8).

Esse processo se deu a vegetação que começou a se expandir através dos ventos e do mar com isso ela foi se expalhando pela vegetação (A23).

Diferente disso, tivemos apenas duas ocorrências de alunos que não apresentaram marcas evidentes da interação nas respostas, mas estavam de acordo com o conhecimento científico como é o caso de A6 (FIGURA 4).

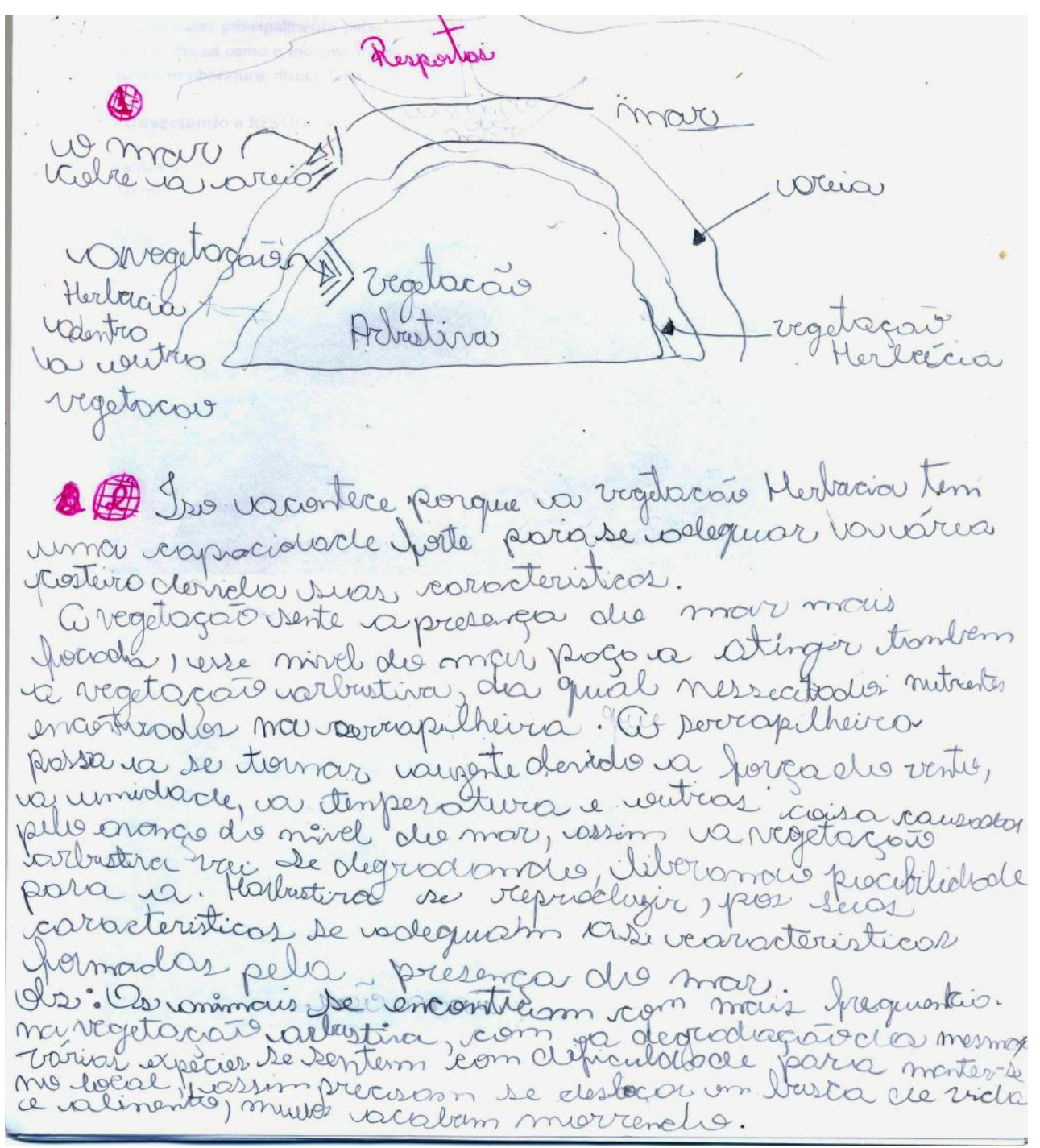

FIGURA 4. Resposta de A6 
No caso de A6, podemos verificar certo grau de autonomia no desenvolvimento de sua resposta. Utilizamos a palavra autonomia no sentido de que o aluno se apresenta mais desenvolvido no processo de internalização de significados, não quer dizer que essas palavras são de única autoria. Fica evidente que o aluno resgata seus conhecimentos prévios no desenvolvimento de sua explicação quando no episódio 4 o aluno lembra a professora que esse assunto já havia sido estudado (EX.9).

Exemplo 9. Episódio 4. Turno 43. Conhecimentos prévios de A6

Pr... a gente viu tudo isso... a gente viu na apostila e no livro que você explicou

Vimos que reinterpretações precisam de um olhar cauteloso quando se trata de conhecimento científico. É valido dizer que a releitura de um dado conhecimento é importante no próprio desenvolvimento e movimento do conhecimento humano. Entretanto, se é de conhecimento científico que estamos falando, a base da releitura será a mesma, ou seja, dificilmente um conhecimento científico será reinterpretado tendo como base o conhecimento comum.

Nesse sentido, ao tratarmos do conhecimento científico, é importante que o comportamento responsivo ativo seja coerente. Ou então, permanecerá no senso comum.

\subsection{SÍNTESE}

Diante do comportamento tanto da professora como dos alunos, vimos claramente o fato de que, segundo Bakhtin (2006) na enunciação é preciso que se tenha o que dizer (conteúdo); se tenha uma razão para dizer (finalidade); se tenha para quem dizer (o outro).

Sendo assim, a mediação da professora em sala de aula refletiu seu comportamento passivo diante da sequência didática, que por apresentar conteúdos e finalidades já estabelecidas, limitou atitudes ativas da professora. Da mesma forma, os alunos tiveram o mesmo comportamento. A compreensão da atividade por parte da 
professora (com conteúdos e finalidades estabelecidas) determinou a compreensão dos alunos sobre a mesma, reproduzindo falas e partes do texto.

Observamos que a maior parte do comportamento responsivo dos alunos foi de transição, ainda carregando consigo a necessidade de reproduzir falas que não são as deles. Possivelmente essas reproduções refletem a necessidade de legitimar o conhecimento que está sendo construído. Tornando dessa forma, o discurso da professora e do texto como discursos confiáveis.

A elaboração da reposta escrita pelo aluno em sala de aula envolveu todo o quadro enunciativo, não se limitando apenas ao momento da pergunta - resposta individual. Isso pode ser visto na grande influência da voz da professora nas respostas dos alunos ao fazer a leitura e a explicação do texto da atividade e também no próprio texto da sequência didática, que carrega um valor social que o aluno utiliza como apoio às suas respostas nas interações aluno-texto.

As cópias de trechos do texto e também da fala da professora poderiam ser interpretadas como uma forma autoritária de leitura por parte da professora. Segundo Kleiman (1993), a noção autoritária de leitura por parte do professor produz um sentido unilateral, apenas uma maneira de abordar o texto e apenas uma interpretação possível que é determinada pelo professor.

Entretanto, no caso do ensino de ciências, isso não é necessariamente algo ruim. Especialmente em textos descritivos (cuja circulação é abundante na comunidade científica), essa visão autoritária pode ser questionável, uma vez que também é importante reproduções de conceitos e definições já aceitas pela comunidade científica como parte de um processo de aprendizado das ciências. $\mathrm{O}$ importante para o processo de alfabetização científica é que conceitos e definições possam ser utilizados em diversos contextos, isso reflete o real entendimento dos conceitos por parte do aluno.

A importância do professor como mediador pode ser vista em A3, uma vez que, ao apresentar dúvida no entendimento do problema requisitou a presença da professora, que a guiou no entendimento da questão, não fornecendo a resposta de imediato, mas desenvolvendo um processo em que elementos foram levantados para 
que a aluna desenvolvesse sua explicação. Dessa forma, sua resposta incorporou elementos desse diálogo e também de partes do material de apoio.

Da mesma forma em que a mediação da professora foi essencial na construção da resposta de A3, a interação do aluno com a professora também conduziu a erros conceituais. Sabendo que reproduções fazem parte do processo de aprendizado das ciências, é importante que alguns termos que são muitas vezes utilizados como metáforas de características humanas, por exemplo, "raízes fortes/fracas" ou a vegetação "invadiu" sejam empregadas com bastante cautela para que o aluno não tenha uma compreensão equivocada. 


\section{CAPÍTULO 7. CONSIDERAÇÕES FINAIS}

Retomando nossa questão de pesquisa "Como é a mediação da professora em uma aula de Ecologia e como isso pode influenciar na produção de explicações escritas pelos alunos?", apresentamos algumas considerações e implicações para o ensino e a pesquisa em ensino de ciências.

Sabemos que existem diversos elementos que fazem parte do quadro enunciativo, tanto em respostas que apresentaram marcas de interação quanto nas que não apresentaram, por isso, esse estudo em particular, obviamente não esgotará tantos possíveis olhares dentro da uma sala de aula. No entanto, por meio desta pesquisa foi possível observar a importância do papel do professor e do material utilizado em sala de aula. O aluno em seu processo de construção de conhecimento apresenta fases em que se apropria de discursos alheios e fases em que a internalização desses discursos já se tornaram um discurso próprio.

Nesse aspecto, no processo de alfabetização científica, é importante que o discurso do professor e o material utilizado em sala de aula estejam conectados, uma vez que os alunos reproduzem tanto o que é considerado cientificamente aceito, mas também termos e ideias equivocadas. Uma vez internalizados os discursos equivocados, mais difícil será a desconstrução desse conhecimento formado.

Vimos que a mediação da professora pode ser influenciada por comportamentos responsivos que não estão exclusivamente na aula dada. No caso desta pesquisa, a interação com o mediador e o contato prévio que a professora teve com o material da sequência didática influenciou sua postura em sala de aula.

A mediação da professora foi caracterizada de forma passiva, uma vez que suas atitudes foram basicamente descritivas, acompanhando a estrutura do roteiro da sequência didática e as instruções do mediador. Consequentemente, esse comportamento influenciou sua aula refletindo um comportamento também passivo na maioria dos alunos.

Essa passividade dos alunos foi demarcada por meio de participações bastante curtas no momento da mediação e também por meio das atitudes de reprodução do conhecimento. 
Tendo em vista esses resultados, é importante que o ensino de ciências pautado na alfabetização científica leve em conta, antes de tudo, o material didático utilizado pelo professor. Um material que não dá possibilidades de criação por parte do professor pode restringir suas atitudes e dos alunos em comportamentos passivos.

Além disso, é importante que o professor tenha em mente os processos de aprendizagem do aluno. Ou seja, reproduzir falas e textos são parte do processo de construção do conhecimento.

Finalizando, são muitas as pesquisas em ensino de ciências em torno das interações estabelecidas entre professor e alunos. Pesquisas essas que tem o olhar na interação propriamente dita. Diferente disso, este trabalho propôs um olhar anterior a esse, ou seja, o que está por trás da maneira como sujeitos interagem. Ou seja, o comportamento responsivo desses sujeitos. 


\section{REFERÊNCIAS}

ANGELO, C. M. P. Compreensão responsiva: aspectos para o ensino da leitura. Anais do I Colóquio Internacional de estudos Linguísticos e Literários; IV CELLI - Colóquio de Estudos Linguísticos e Literários. Maringá, 2010.

ANGELO, C. M. P.; MENEGASSI, R. J. Manifestações de compreensão responsiva em avaliações de leitura. Linguagem \& Ensino, v.14, n.1, p.201-221, 2011.

BAKHTIN, M. Estética da criação verbal. 2ª edição, São Paulo: Martins Fontes, 1997.

BAKHTIN, M. (VOLOCHINOV) Marxismo e Filosofia da Linguagem. 12a edição, São Paulo: Hucitec, 2006.

BAQUERO, R. Vygotsky e a aprendizagem escolar. Porto Alegre: Artmed, 2001.

BLANCK, G. Vygotsky: o homem e sua causa. In: MOLL, L. C. (org) Vygotsky e a educação: implicações pedagógicas da psicologia sócio-histórica. Porto Alegre: Artes Médicas, 1996.

BRAGA, S. A. M. ; MORTIMER, E. F. Elementos do gênero de discurso científico no texto de Biologia do livro didático de Ciências. In: IV Encontro Nacional de Pesquisa em Educação em Ciências, 2003, Bauru - SP. Anais do IV Encontro Nacional de Pesquisa em Educação em Ciências. Belo Horizonte : ABRAPEC, 2003.

BRAIT, B.; MELO, R. Enunciado/enunciado concreto/enunciação. In: BRAIT, B. (org.) Bakhtin: conceitos-chave. São Paulo: Contexto, 2005.

CACHAPUZ, A.; GIL-PEREZ, D.; CARVAlho, A. M. P.; PRAIA, J.; VILCHES, A. (Orgs.). A necessária renovação do ensino das ciências. São Paulo: Cortez, 2005.

CAPECCHI, M. C. V. M. ; CARVALHO, A. M. P. . Aspectos da cultura científica numa atividade de laboratório aberto de física. In: IX Encontro de Pesquisa em Ensino de Física, 2004, Jaboticatubas. Anais do IX Encontro de Pesquisa em Ensino de Física, 2004.

CARVALHO, A.M.P. Metodologia de pesquisa em ensino de física: uma proposta para estudar os processos de ensino e aprendizagem. In: IX Encontro de Pesquisa em Ensino de Física, 2004, Jaboticatubas. Anais do IX Encontro de Pesquisa em Ensino de Física, 2004.

CHASSOT, A. Alfabetização científica: questões e desafios para a educação. ljuí: Editora da Unijuí, 2000. 
DRIVER, R.; ASOKO, H.; LEACH, J.; MORTIMER, E.; SCOTT, P. Construindo conhecimento científico na sala de aula. Química Nova na Escola, v. 9, p. 31-40, 1999.

DRIVER, R.; NEWTON, P.; OSBORNE, J. Establishing the norms of scientific argumentation in classrooms. Science Education, v. 20, p. 1059-1073, 2000.

ERDURAN, S. Promoting ideas, evidence and argument in initial science teacher training. School Science Review, v. 87, p. 45-50, 2006.

FREIRE, P. Educação como prática da liberdade. Rio de Janeiro: Paz e Terra, 1980.

GUISASOLA, J.; FURIÓ, C.; CEBERIO, M. Science education based on developing guided research. In: Thomase M.V. (Ed.). Science Education in Focus. 2006.

HALLIDAY, M. A. K.; MARTIN, J. R. Writing Science: Literacy and Discursive Power. Pittsburgh, Pa: University of Pittsburgh Press, 1993.

JIMÉNEZ-ALEIXANDRE, M. P. La Catástrofe del Prestige: Racionalidad Crítica versus Racionalidad Instrumental. Cultura y Educación, v.16, n.3, 305-319, 2004.

KLEIMAN, A. Oficina de leitura: teoria e prática. Campinas. Pontes: ed. Unicamp, 1993.

LORENZETTI, I. DELIZOICOV, D. Alfabetização científica no contexto das séries iniciais ENSAIO: Pesquisa em educação em ciências, v. 3, n.1, 2001.

MÁRQUEZ, C.; PRAT, A. Leer en clase de ciencias. Enseñanza de lãs ciencias, v. 23 n.3, p. 431-440, 2005.

MASSERON, C. Présentation. Pratiques, v. 92, p. 3-4. 1996.

MENEGASSI, R. J. Aspectos da responsividade na interação verbal. Revista Línguas e Letras, v. 10, n. 18, 2009.

MORTIMER, E. F., CHAGAS, A. N., ALVARENGA, V. T. Linguagem Científica Versus Linguagem Comum Nas Respostas Escritas de Vestibulandos. INVESTIGAÇÕES EM ENSINO DE CIÊNCIAS. PORTO ALEGRE: UFRGS, v.3, n.1, p.1 - 13, 1998.

NORRIS, S. P.; PHILLIPS, L. M. How literacy in its fundamental sense is central to scientific literacy. Science Education. v. 87, p. 224-240, 2003.

OLIVEIRA, C. M. A. e CARVALHO, A. M. P. Escrevendo em Aulas de Ciências.

Ciências e Educação, v. 11, n. 3, P. 347-366, 2005.

PANCERA, N. K. Linguagem, enunciação, enunciado-ponto de partida para o ensino de língua portuguesa. Educere, v.2, n1, 2002.

PETRI, D. O discurso oral culto. São Paulo. Humanitas Publicações, 1999. 
REGO, C.R. (1998). Vygotsky: uma perspectiva histórico-cultural da educação. 5. ed. Petrópolis, Rio de Janeiro: Vozes, 1998.

SANTOS, W. L. P.; MORTIMER, E. F. Tomada de decisão para ação social responsável no ensino de ciências. Ciência \& Educação, Bauru, v. 7, n. 1, p. 95-111, 2001.

SASSERON, L. H; CARVALHO, A. M. P. Almejando a alfabetização científica no ensino fundamental: a proposição e a procura de indicadores do processo. Investigações em Ensino de Ciências, v. 13, n.3, p. 333-352, 2008.

SASSERON, L. H.; CARVALHO, A. M. P. Alfabetização científica: uma revisão bibliográfica. Investigações em Ensino de Ciências, Porto Alegre, v. 16, n.1, p. 59-77, 2011.

SMOLKA, A. L. B. A prática discursiva na sala de aula: uma perspectiva teórica e um esboço de análise. In: Cadernos Cedes, n. 24, Campinas: Papirus, 1991, p.51-65.

SUGIYAMA, M. Estudo de florestas da restinga da llha do Cardoso, Cananéia, São Paulo, Brasil. Boletim do Instituto de Botânica, v.11, p.119-159, 1998.

VILLANI, C.E.P.; NASCIMENTO, S.S. A argumentação e o ensino de Ciências: uma atividade experimental no laboratório didático de física do ensino médio. Investigações em Ensino de Ciências, v. 8, n.3, p. 1-15, 2003.

VYGOTSKY, L. S. A formação social da mente. São Paulo: Martins Fontes, 1999. . Pensamento e linguagem. São Paulo: Martins Fontes, 1989. 


\section{APÊNDICES}

\section{APÊNDICE 1 - SEQUÊNCIA DIDÁTICA}

\section{ATIVIDADE 1 \\ JORNAL da CIÊNCIA \\ PUBLICAÇĀO DA SBPC - SOCIEDADE BRASILEIRA PARA O PROGRESSO DA CIÊNCIA • RIO DE JANEIRO, 27 DE MAIO DE 2011 - ANO XXIV N 690 • ISSN 1414-655X}

0 avanço do mar

Pesquisa da USP revela que o nível do oceano no Brasil sobe $4 \mathrm{~mm}$ por ano. Índice é considerado alto e coloca em risco áreas litorâneas do país.

"Não há dúvida de que o nível do mar tem aumentado gradativamente no litoral brasileiro." A conclusão consta de estudo realizado pelo Instituto Oceanográfico da Universidade de São Paulo (IO/USP). O alerta significa que o país pode sofrer, no futuro, com uma das piores consequências do aquecimento global: a destruição de regiões inteiras localizadas próximo à costa.

As possíveis consequências do fenômeno vão da perda da faixa de areia à destruição de cidades, passando por ressacas mais violentas e inúmeros outros transtornos.

Milton Kampel, especialista do Instituto Nacional de Pesquisas Espaciais (Inpe) diz que a elevação do oceano preocupa porque as regiões costeiras costumam ter alta densidade populacional. "Milhões de pessoas vivem numa faixa entre $1 \mathrm{~m}$ e $5 \mathrm{~m}$ da linha de costa."

Trecho extraído de: $\underline{\text { http://www.jornaldaciencia.org.br/Detalhe.jsp?id=71786 }}$

E cada vez mais, casas e edifícios são construídos ao longo das planícies litorâneas para abrigar essa quantidade enorme de pessoas. E consequentemente, a vegetação ali existente, a Restinga, é devastada. Hoje em dia, são poucas as Restingas ainda preservadas em todo o Brasil. Observe o contraste entre as duas fotos:

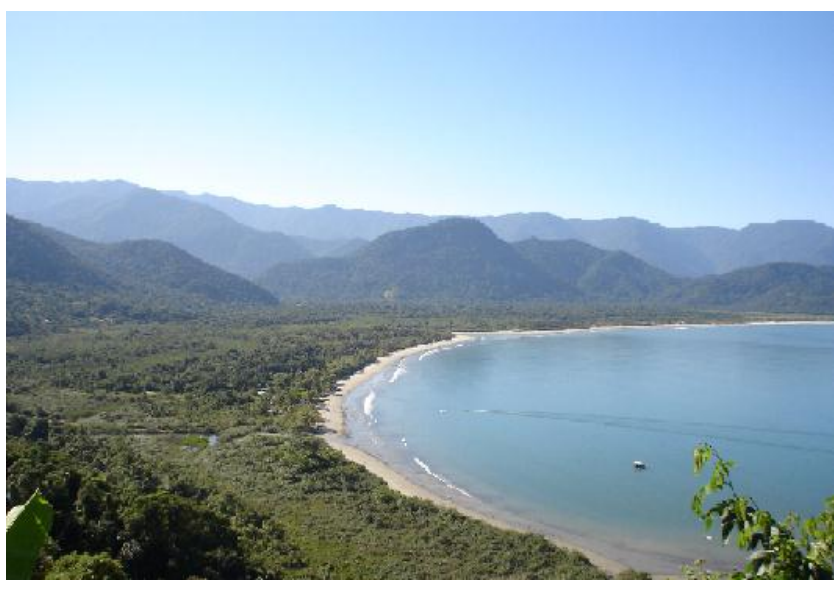

(Fig.1) Restinga do Estaleiro. Ubatuba/São Paulo

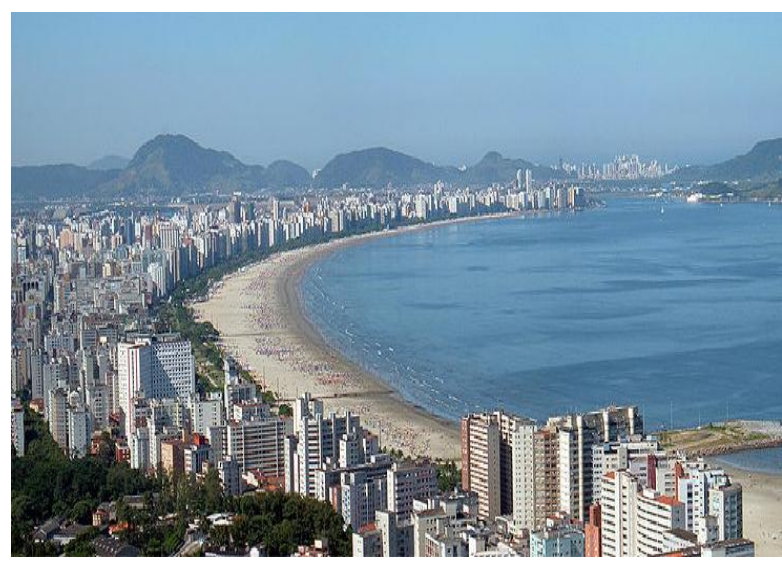

(Fig. 2) Praia de Santos. Santos/São Paulo 
Na figura 1, a Restinga (toda vegetação ao longo da planície, desde a linha da praia até a encosta das montanhas) está preservada. Já na figura 2, toda área onde havia a Restinga está ocupada com prédios e outras construções.

Como vimos no início no Jornal da Ciência, a elevação do nível do mar está, na maioria das vezes, associado à destruição de cidades litorâneas (fig.3). E, constantemente, é possível encontrar essas informações na televisão e também na internet.

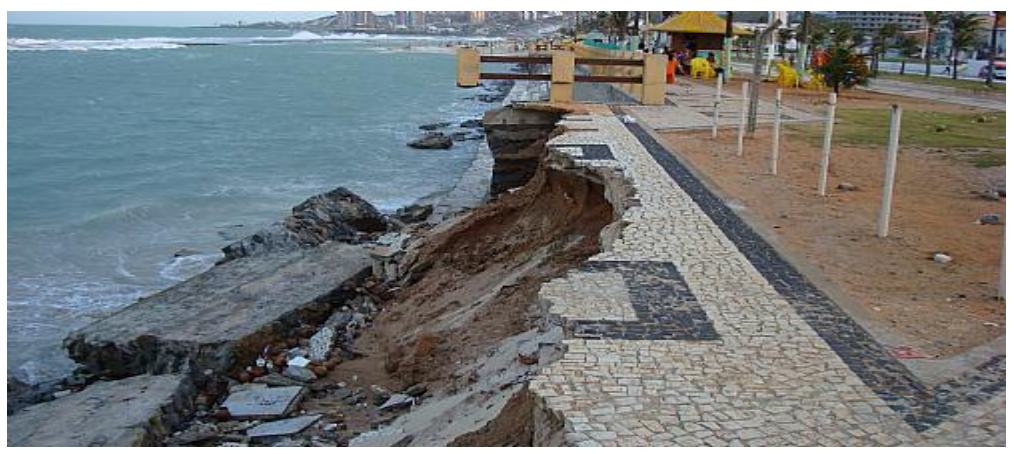

(Fig. 3)

Porém, pouco se fala das conseqüências da elevação do nível do mar nas áreas em que a vegetação ainda é preservada.

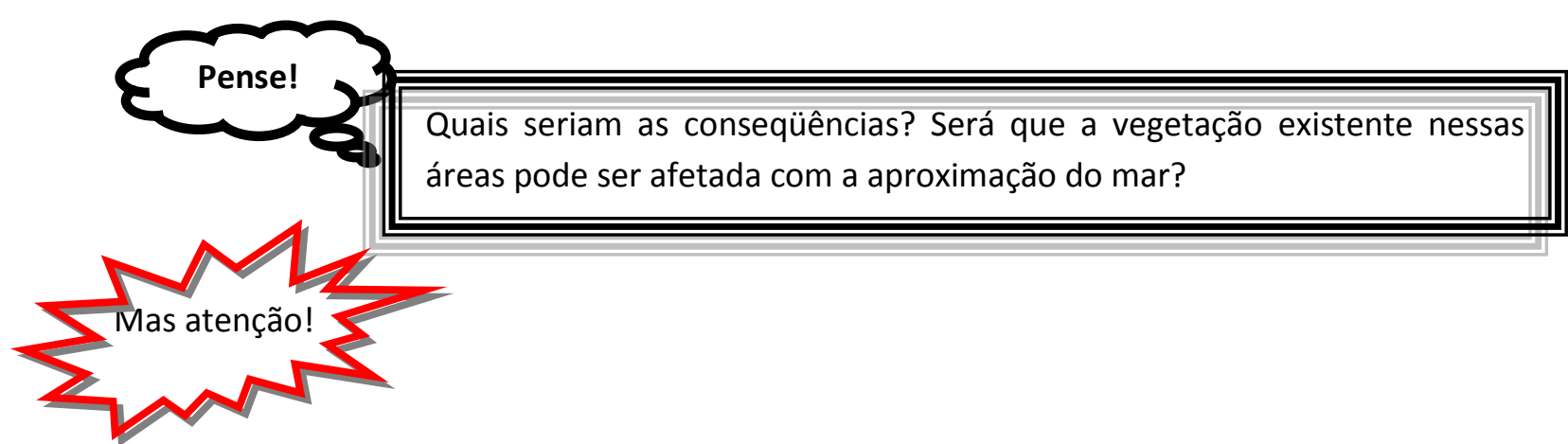

É claro que se o volume das águas do mar subisse de uma só vez e cobrisse toda a planície litorânea, toda Restinga iria por "água a baixo" e deixaria de existir. Mas estamos falando de um aumento no nível do mar que ocorre aos poucos, diminuindo a faixa de areia entre a vegetação e o mar. Ou seja, o

Dessa forma, você acredita que, com a aproximação do mar em áreas preservadas:

(3) A vegetação não é afetada, pois

Se a aproximação do mar não afeta a vegetação, então esperamos que

OU

(4) A vegetação pode ser afetada, pois

Se a aproximação do mar afeta a vegetação, então esperamos que 


\section{ATIVIDADE 2}

As seguintes imagens aéreas foram desenvolvidas a partir de uma região da llha do Cardoso localizada litoral no sul de São Paulo ( fig.1), onde a Restinga é preservada. A figura 2 corresponde ao antes e o depois: observe a diferença de largura da faixa de areia da praia das figuras $(A)$ e $(B)$ :

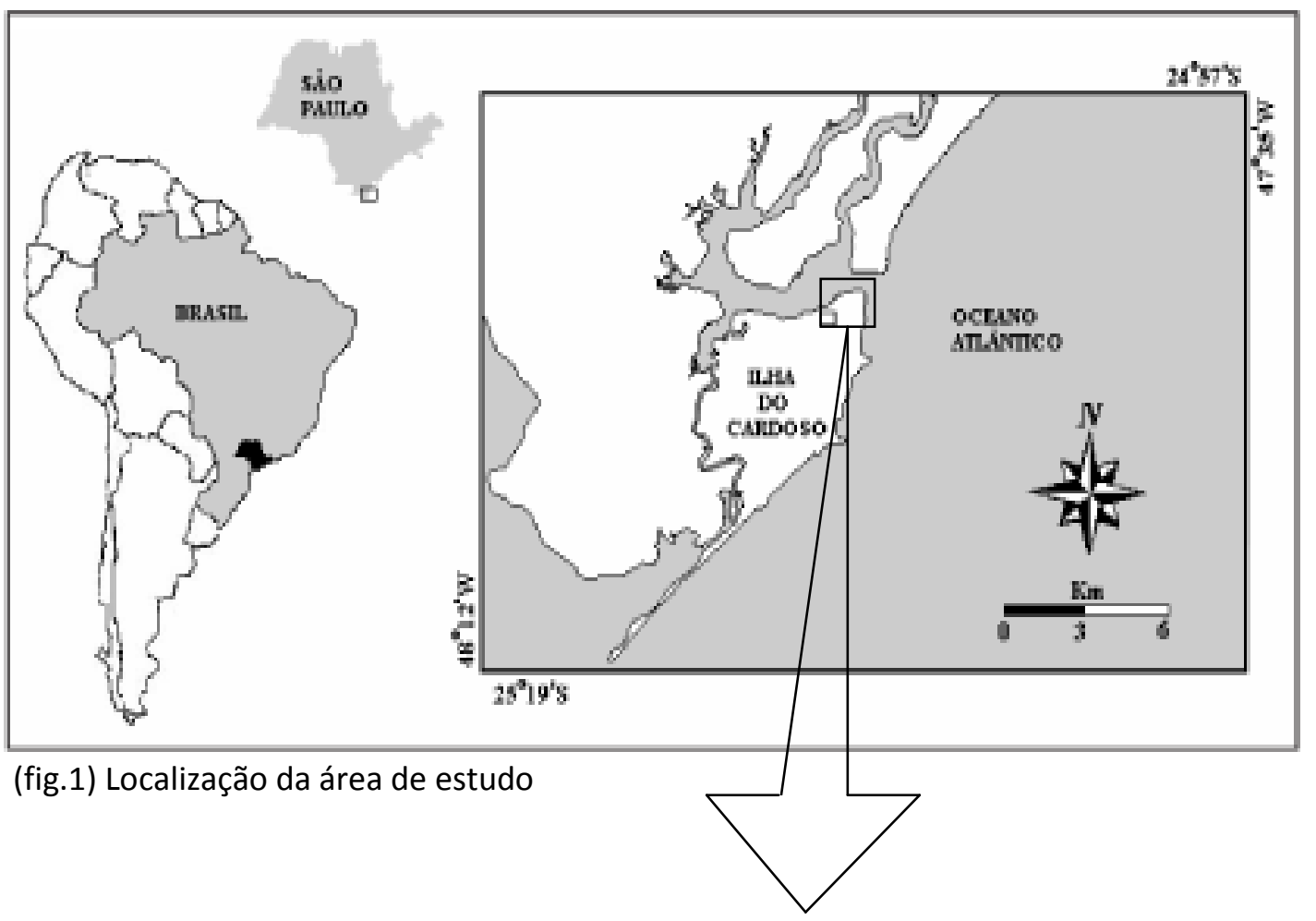

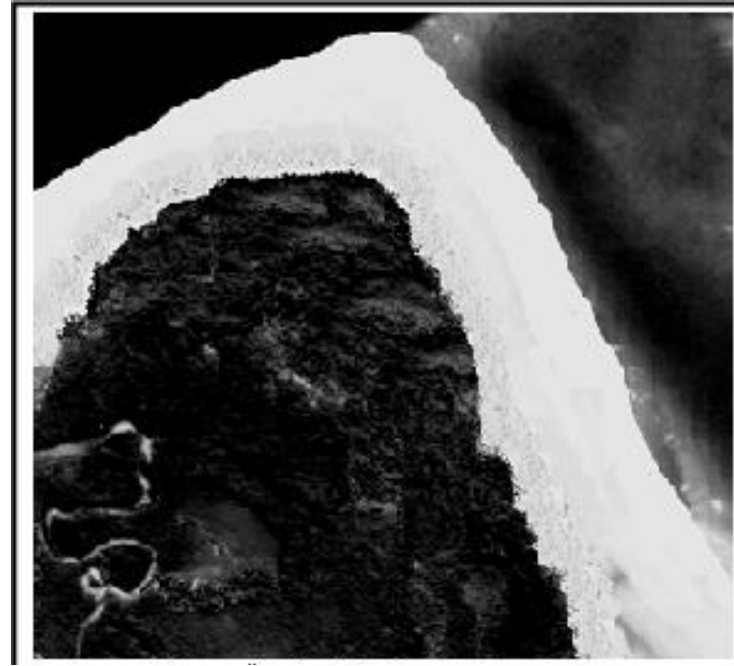

A. Antes da elevação do nível do mar

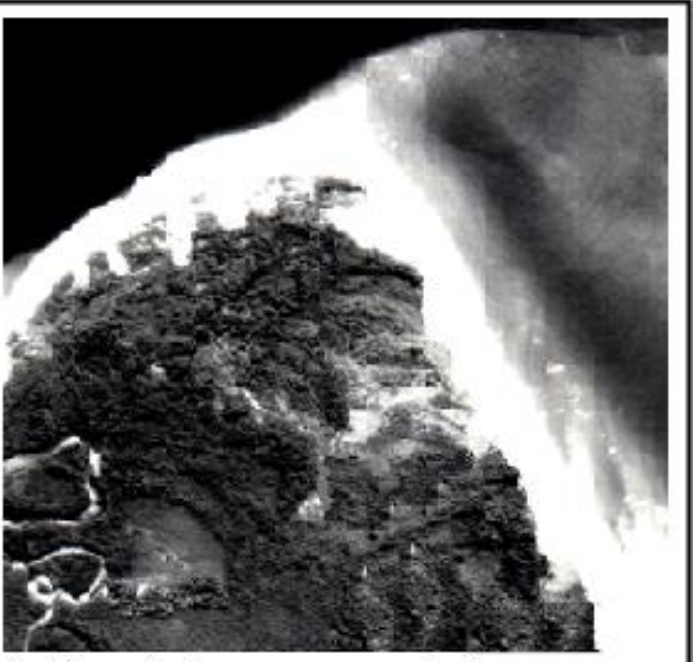

B. 15 anos depois com a aproximação do mar

A figura B apresenta a faixa da praia mais estreita que a figura A, caracterizando elevação do nível do mar na região no decorrer desses 15 anos. 
Agora observe o que acontece com a vegetação:
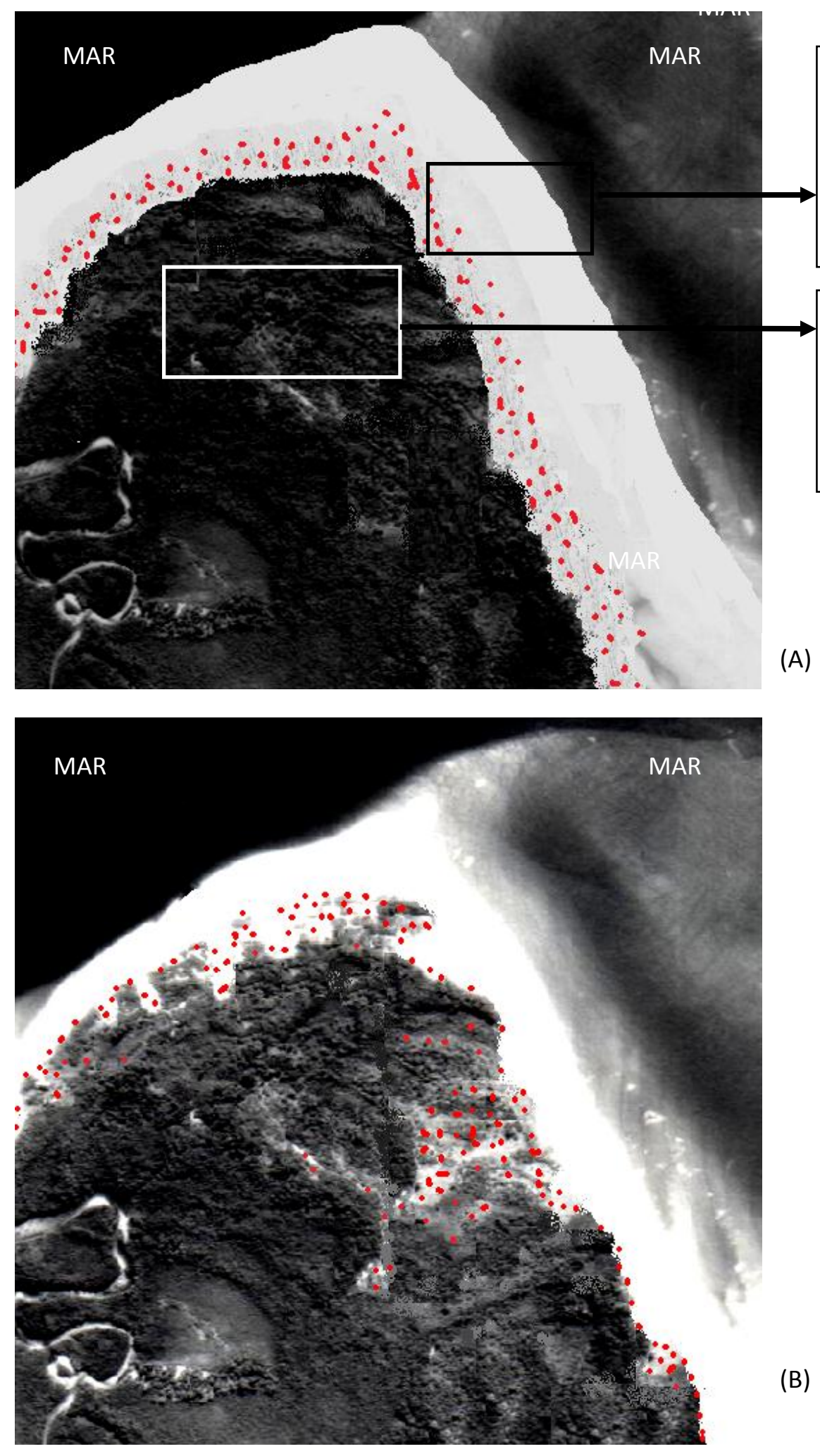

(B) 
Perceba que antes, a vegetação herbácea predominava na faixa da praia beirando a vegetação arbustiva (A). Com a aproximação do mar (B) a vegetação herbácea começou a aparecer com mais frequencia nas regiões onde antes a vegetação arbustiva era mais concentrada.

Agora, com base no material de apoio, responda:

5 Por que, com a aproximação do mar, a vegetação herbácea começou a aparecer com mais freqüência onde antes predominava a vegetação arbustiva?

6 Como se deu esse processo? 


\section{MATERIAL DE APOIO}

\section{Conhecendo a RESTINGA}

A RESTINGA apresenta um conjunto diversificado de vegetações que ocupam as planícies litorâneas. As vegetações possuem diferentes características que mudam à medida que se distanciam do mar. São influenciadas principalmente pelas condições do solo (drenagem da água, disponibilidade de nutrientes) e fatores físicos como o movimento das areias pelo vento, o atrito dos grãos de areia, vento forte, incidência do sol, temperatura, disponibilidade de água, salinidade, entre outros.

\section{Atravessando a RESTINGA}

Vamos imaginar que acabamos de desembarcar em uma praia e seguimos em frente em direção à encosta das montanhas como indica a seta abaixo (fig.1):

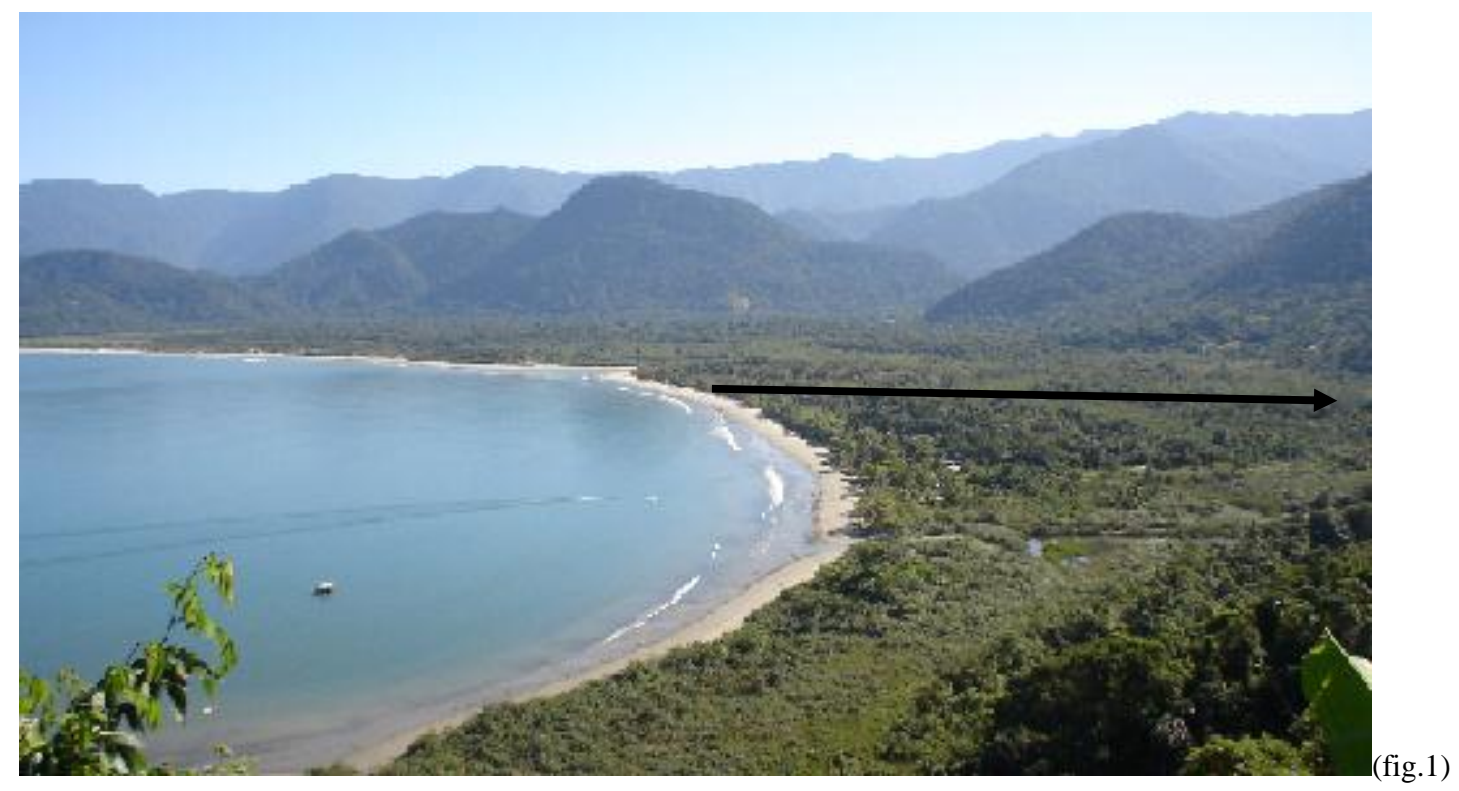

Saindo do mar, há alguns passos sobre a areia e fora da área de ação das marés, nos deparamos com uma vegetação rasteira que chega a aproximadamente $40 \mathrm{~cm}$ de altura e se espalha sobre o chão. São tufos de capim e plantas de ramos muito finos e moles que crescem e se reproduzem rapidamente. Essa é a vegetação herbácea (fig.2). 


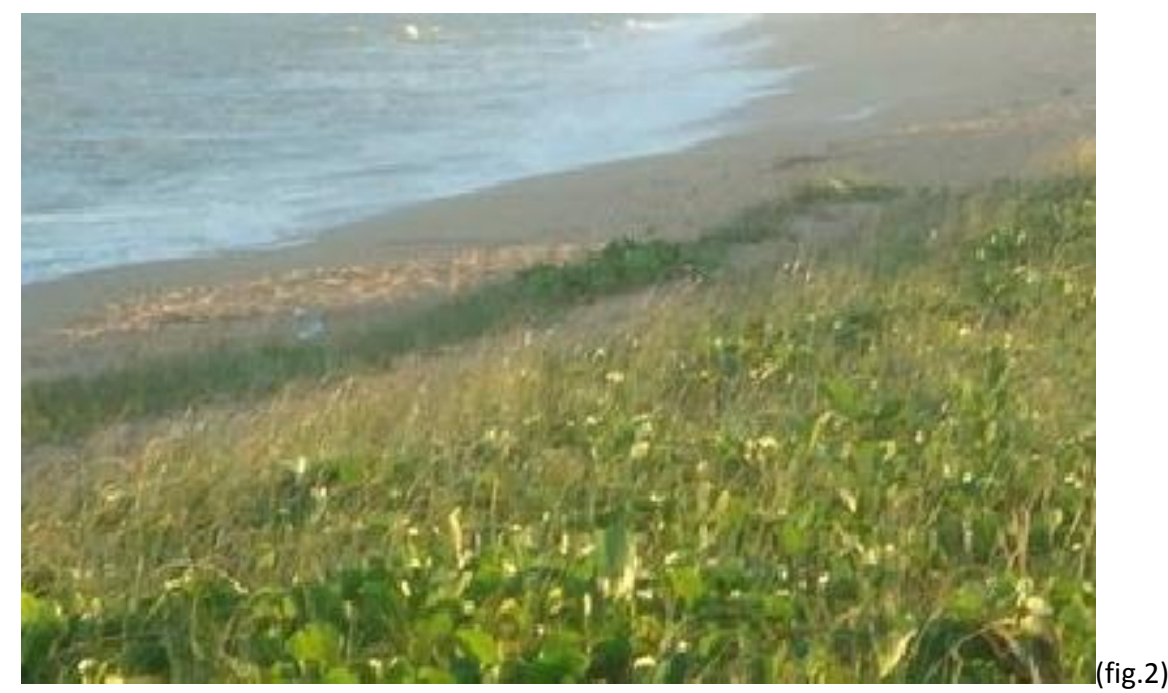

A vegetação herbácea possui raízes bastante profundas e sistemas de raízes e rizomas (fig.3) que fixam as plantas na areia e as mantém mais estáveis, já que a areia da praia se movimenta com muita facilidade devido ao vento.

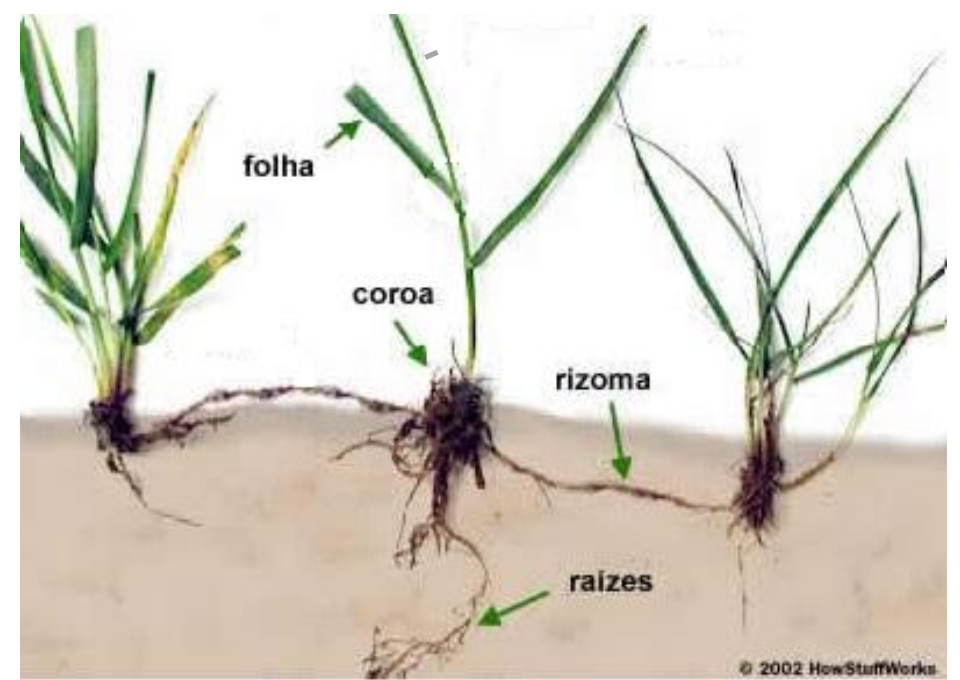

(fig.3)
Esse tipo de planta é de grande importância nesses ambientes, pois a areia que fica aderida em suas coroas e no emaranhado de suas raízes dificulta que $o$ vento carregue grandes quantidades dessa areia em direção ao interior.

Suas folhas finas, longas e flexíveis são resistentes ao vento forte dessa região e, além disso, possuem grande facilidade de regeneração quando rompidas.

Outra planta que também vive nessa região é a salsa-da praia (fig4). Ela possui folhas e hastes mais rígidas e espessas que protege contra a perda de água, contra o sal que chega com a maresia e também contra o desgaste provocado pelo atrito dos grãos de areia trazidos pelo vento. 


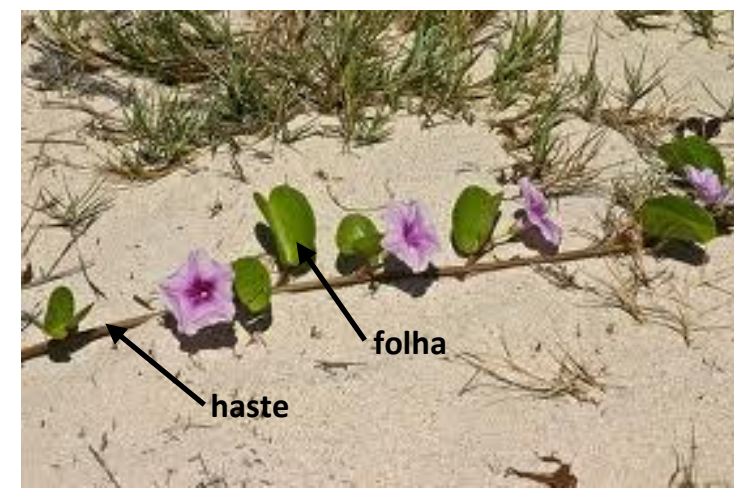

Fig.4

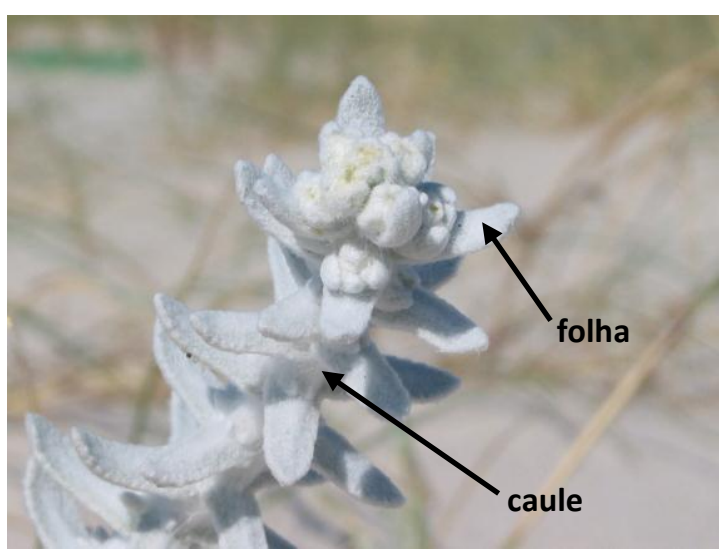

Fig.6
Um exemplo interessante é o cordeiro-da-praia (fig.5). Essa planta possui pêlos esbranquiçados que refletem a luz do sol protegendo-as, além disso, também possui caule e folhas suculentas que armazenam água.

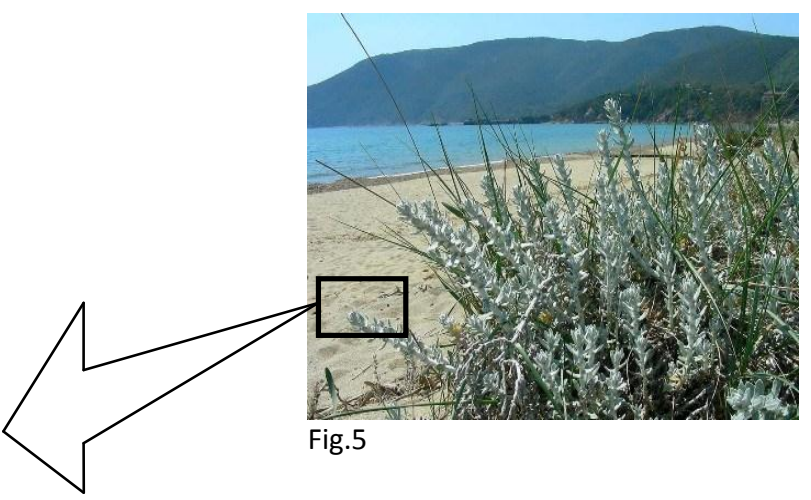

Continuando o nosso percurso, após a vegetação herbácea, as plantas começam a ficar mais altas e andar entre elas começa a ficar difícil pois a vegetação é muito mais densa: é a vegetação arbustiva (fig.7), que pode chegar a 3 metros de altura.

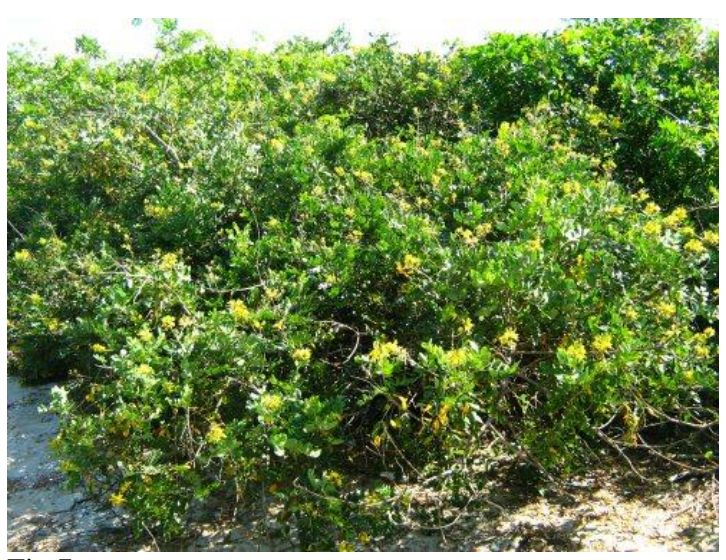

Fig.7

Essas plantas recebem menor influência da ação do mar (salinidade) e dos ventos. $O$ terreno é mais estável, e as condições de fixação das raízes das plantas melhoram. Dependendo da época do ano, ocorre acúmulo de água da chuva. E ao contrário da região onde predominam as herbáceas, existe sobre o solo da vegetação arbustiva, uma camada fina de serrapilheira 
(restos vegetais como folhas, caules, frutos, flores) que entra em decomposição e fornece nutrientes para as plantas (fig. 8).

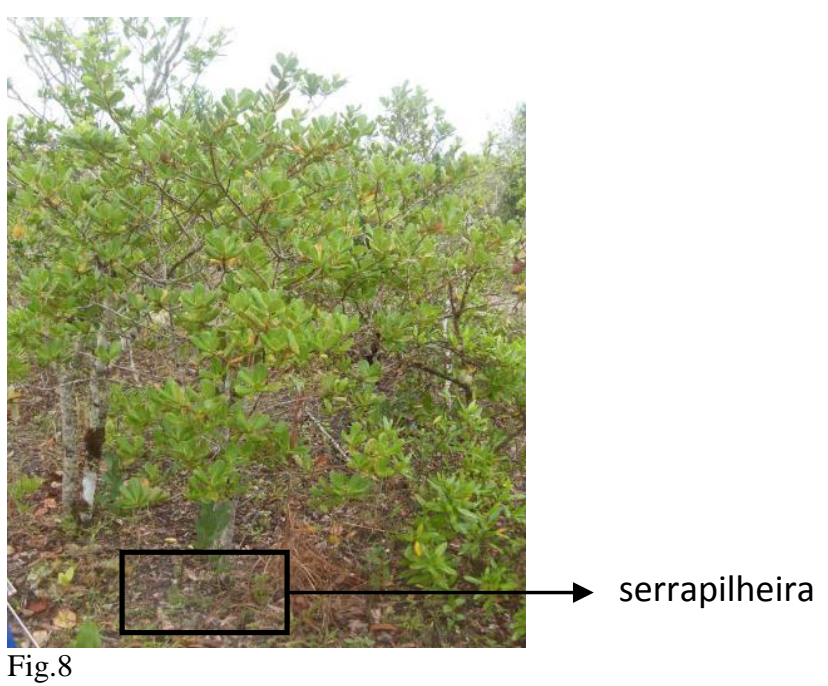

Em seguida, continuando o caminho em direção à encosta das montanhas, começam a aparecer árvores que podem chegar até 20 metros de altura. É a Floresta de Restinga (Fig. 9).

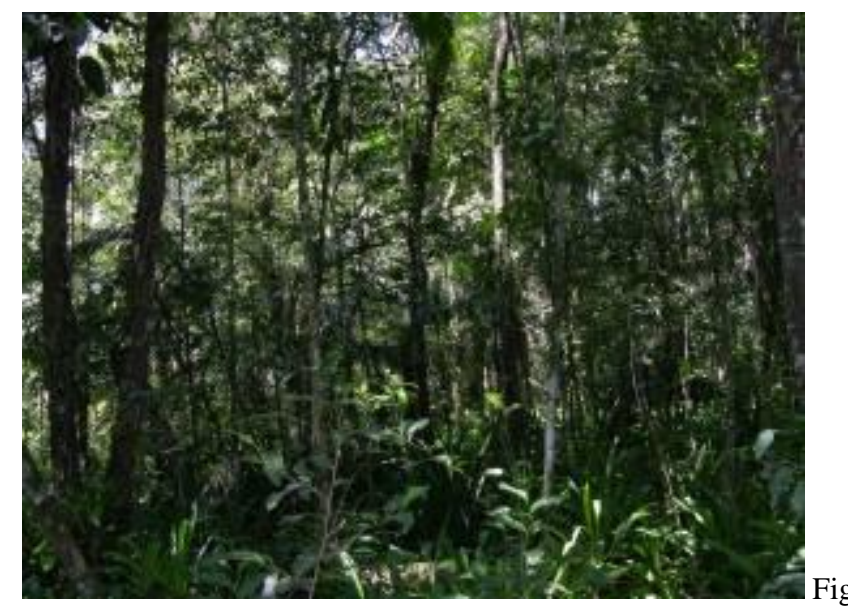

A mata começa a ficar mais fechada e o ambiente é bem mais úmido. Há grande disponibilidade de nutrientes nessa região em comparação com as anteriores. Aqui, podemos perceber que existem muitas espécies de plantas diferentes e em grande quantidade, o inverso do que ocorre na região das praias, onde há apenas poucas espécies adaptadas às condições daquele $\varepsilon$ ambiente. 


\section{APÊNDICE 2 - ROTEIRO DO PROFESSOR}

\section{Roteiro do professor - Sequência Didática-Restinga}

Cabe ao professor aplicar a sequência didática em sala de aula conforme instruções do mediador. Informar ao mediador sobre adequações as quais achar conveniente para o contexto de cada sala de aula. Porém, é importante que as adequações não interfiram no objetivo da sequencia didática. Durante a aplicação da sequencia, o professor se orientará pelos passos descritos abaixo, porém é importante que tenha em mente sua total autonomia durante a aula, não se limitando à leitura da atividade, mas interagindo com os alunos da maneira como achar conveniente.

\section{Desenvolvimento da sequencia didática}

Objetivo central: é que, a partir de um problema, os alunos possam elaborar textos escritos argumentativos tendo como base a leitura de um texto descritivo em que é tratada relações entre fatores abióticos e estruturas adaptativas de plantas da Restinga.

Conteúdo a ser ensinado: Na Restinga, a proximidade do mar atua como fator fortemente seletivo para a instalação e crescimento da vegetação. As plantas são sujeitas a: ventos fortes carregados de partículas de sal, luminosidade excessiva, escassez de nutrientes, grande instabilidade e reduzida disponibilidade de água devido à alta permealidade dos terrenos arenosos. Conforme se distancia do mar, observa-se que há modificações na vegetação as quais refletem as condições do solo que tornam-se mais estáveis, firmes, com menor permeabilidade e maior disponibilidade de nutrientes. As fisionomias tornam-se mais complexas a medida que estão mais distantes do mar.

\section{Descrição da sequencia didática: passo-a-passo}

Entregue aos alunos somente a atividade 1 .

A atividade tem início com um trecho de um artigo publicado no Jornal da Ciência que traz dados referentes à elevação do nível do mar e suas consequências para as cidades litorâneas.

Esse texto tem o objetivo de aproximar o aluno de questões que estão na mídia referente ao aquecimento global e as relações entre a elevação do nível do mar e a destruição de cidades litorâneas. Leia o texto em voz alta e explique se necessário.

\section{JORNAL da CIÊNCIA}

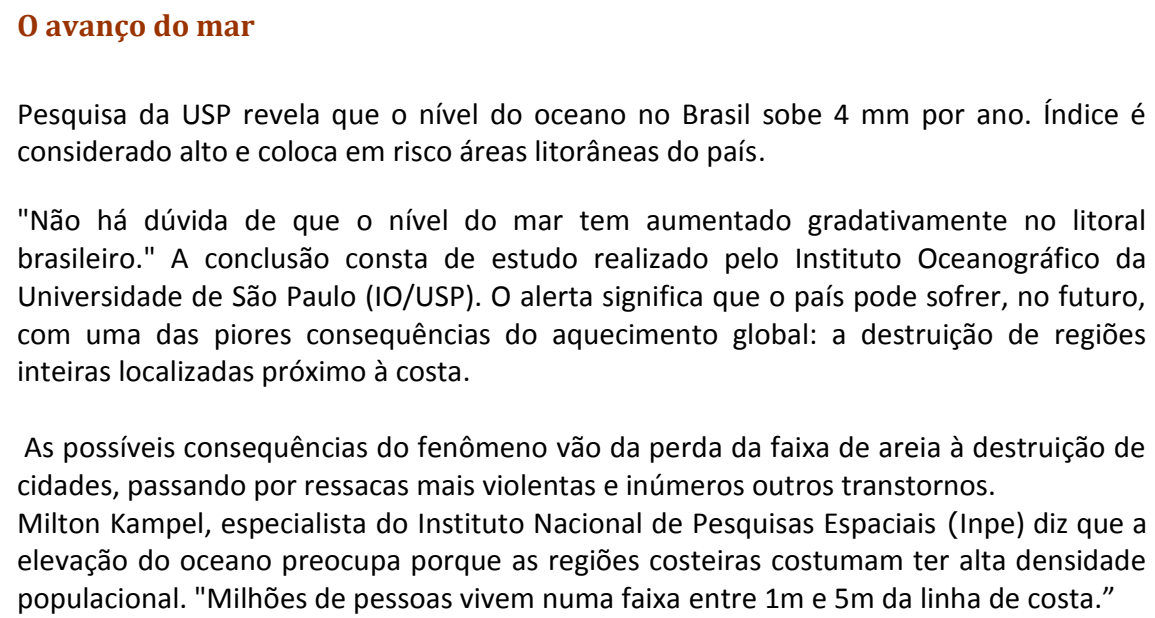

"Não há dúvida de que o nível do mar tem aumentado gradativamente no litoral brasileiro." A conclusão consta de estudo realizado pelo Instituto Oceanográfico da Universidade de São Paulo (IO/USP). O alerta significa que o país pode sofrer, no futuro, com uma das piores consequências do aquecimento global: a destruição de regiões inteiras localizadas próximo à costa.

As possíveis consequências do fenômeno vão da perda da faixa de areia à destruição de cidades, passando por ressacas mais violentas e inúmeros outros transtornos.

Milton Kampel, especialista do Instituto Nacional de Pesquisas Espaciais (Inpe) diz que a elevação do oceano preocupa porque as regiões costeiras costumam ter alta densidade populacional. "Milhões de pessoas vivem numa faixa entre $1 \mathrm{~m}$ e $5 \mathrm{~m}$ da linha de costa." 
Seguimos com a leitura do texto da atividade ressaltando a ocupação de cidades litorâneas. Não será necessário explicar aos alunos a definição de Restinga nesse momento, dizer que é a vegetação característica do local (como diz o texto) é suficiente.

E cada vez mais, casas e edifícios são construídos ao longo das planícies litorâneas para abrigar essa quantidade enorme de pessoas. E consequentemente, a vegetação ali existente, a Restinga, é devastada. Hoje em dia, são poucas as Restingas ainda preservadas em todo o Brasil.

A seguir temos duas fotos que fotos ilustram o contraste entre uma planície com a vegetação de Restinga ainda preservada e outra ocupada pela cidade.

Mostre aos alunos o que é a planície, a vegetação de Restinga sobre ela (fig1) e o contraste da cidade construída sobre a planície.

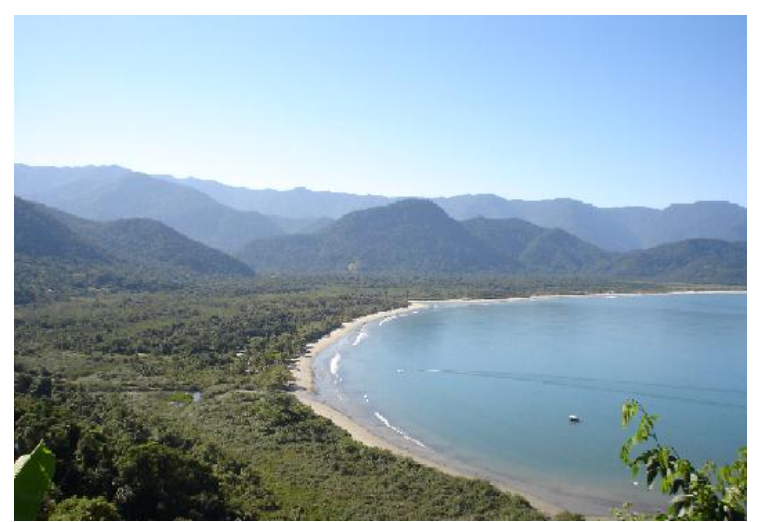

(Fig.1) Restinga do Estaleiro. Ubatuba/São Paulo

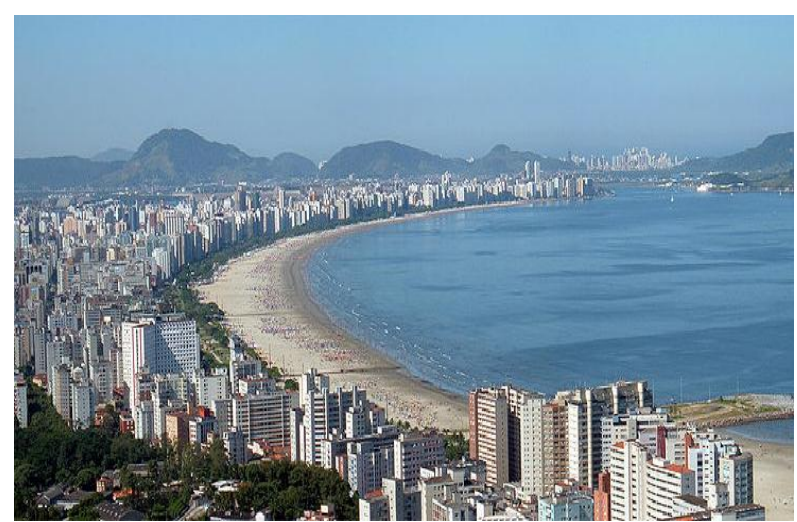

(Fig. 2) Praia de Santos. Santos/São Paulo

Na figura 1, a Restinga (toda vegetação ao longo da planície, desde a linha da praia até a encosta das montanhas) está preservada. Já na figura 2, toda área onde havia a Restinga está ocupada com prédios e outras construções.

Mais uma vez evidenciamos a relação "elevação do nível do mar - cidades" e destacamos a divulgação disso na mídia. Ao contrário de " elevação do nível do mar - vegetação" que dificilmente se discute. Esse é o gancho para que os alunos reflitam sobre o que poderia acontecer com essas áreas preservadas em consequencia da elevação do nível do mar

Vimos no início da atividade que a elevação do nível do mar está, na maioria das vezes, associado à destruição de cidades litorâneas (fig.3). E, constantemente, é possível encontrar essas informações nos jornais, na televisão e na internet. 


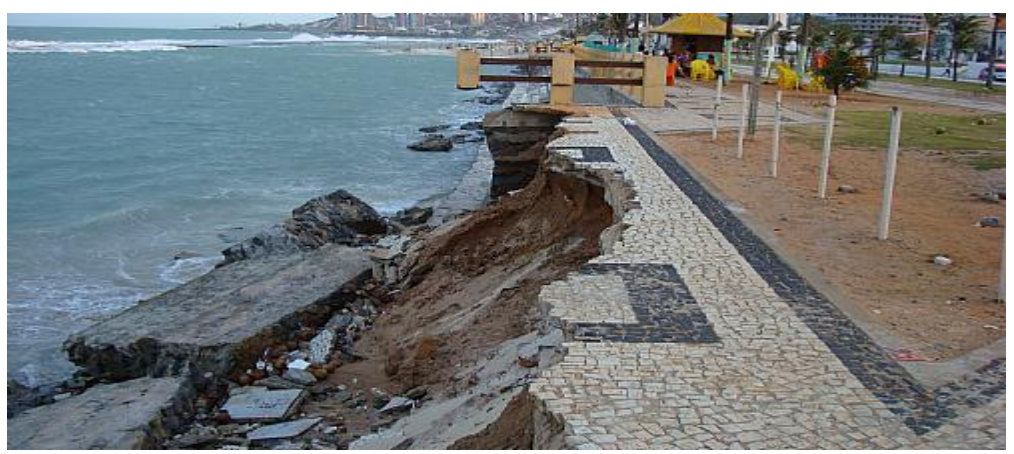

(Fig. 3)

Porém, pouco se fala das consequiências da elevação do nível do mar nas áreas em que a vegetação ainda é preservada.

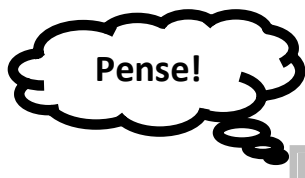

Quais seriam as conseqüências? Será que a vegetação existente nessas áreas pode ser afetada com a aproximação do mar?

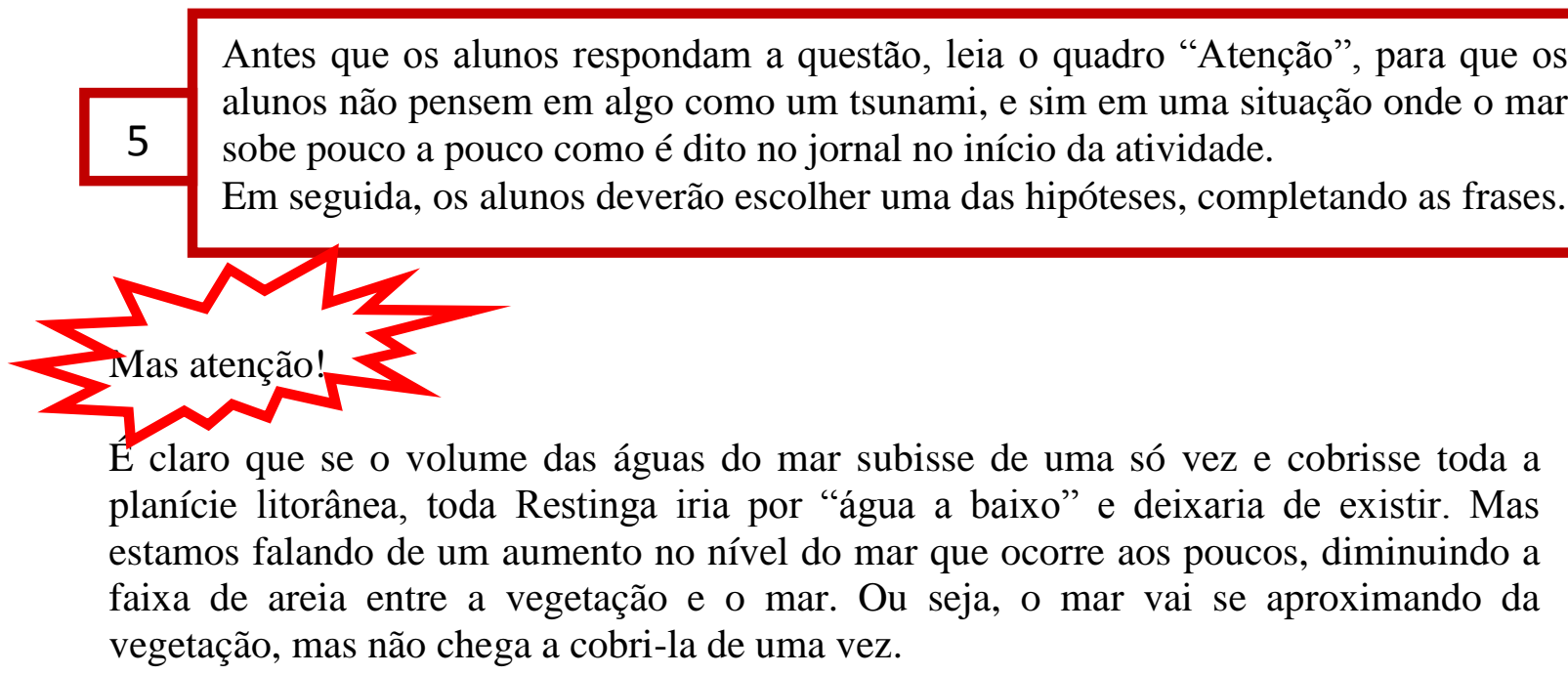

Dessa forma, você acredita que, com a aproximação do mar em áreas preservadas:

(5) A vegetação não é afetada, pois

Se a aproximação do mar não afeta a vegetação, então esperamos que

$\mathrm{OU}$

(6) A vegetação pode ser afetada, pois

Se a aproximação do mar afeta a vegetação, então esperamos que 
Explique aos alunos que as hipóteses levantadas da atividade anterior serão discutidas no fim de toda a sequencia didática.

Entregue a Atividade 2 para os alunos e diga que veremos o que PODERIA acontecer com a elevação do nível do mar em regiões de Restinga preservada.

Explique o detalhe das ampliações do mapa e que as fotos (fig.2) são vistas de cima de um ponto da Ilha do Cardoso. Mostre também a sua localização.

Mostre a diferença entre a largura da faixa de praia da figura 1 e 2 , evidenciando a elevação do nível do mar.

\section{ATIVIDADE 2}

As seguintes imagens aéreas foram desenvolvidas a partir de uma região da Ilha do Cardoso localizada litoral no sul de São Paulo (fig.1), onde a Restinga é preservada. A figura 2 corresponde ao antes e o depois: observe a diferença de largura da faixa de areia da praia das figuras (A) e (B):
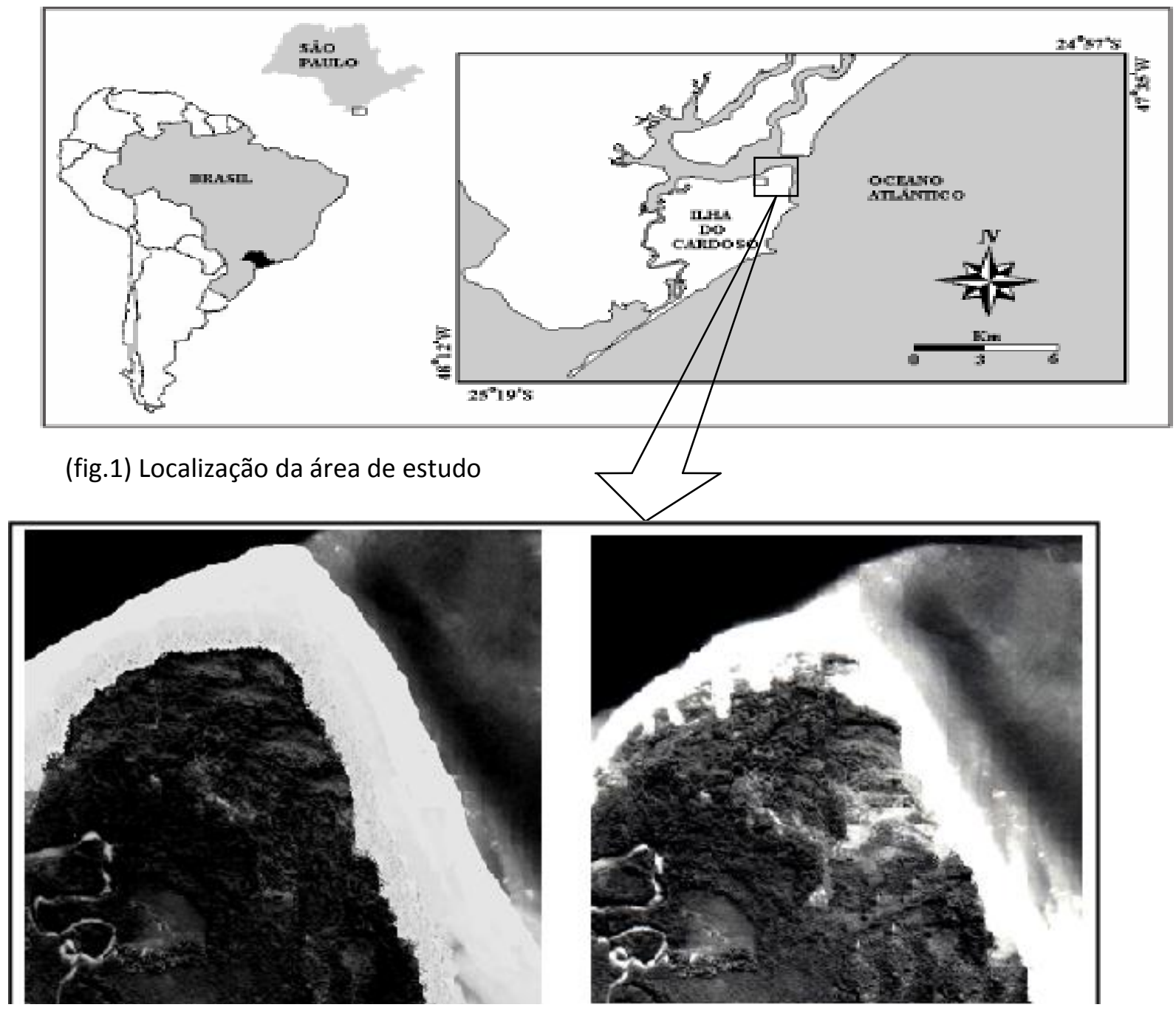

A. Antes da elevação do nível do mar

B. 15 anos depois com a aproximação do mar

A figura B apresenta a faixa da praia mais estreita que a figura A, caracterizando elevação do nível do mar na região no decorrer desses 15 anos. 


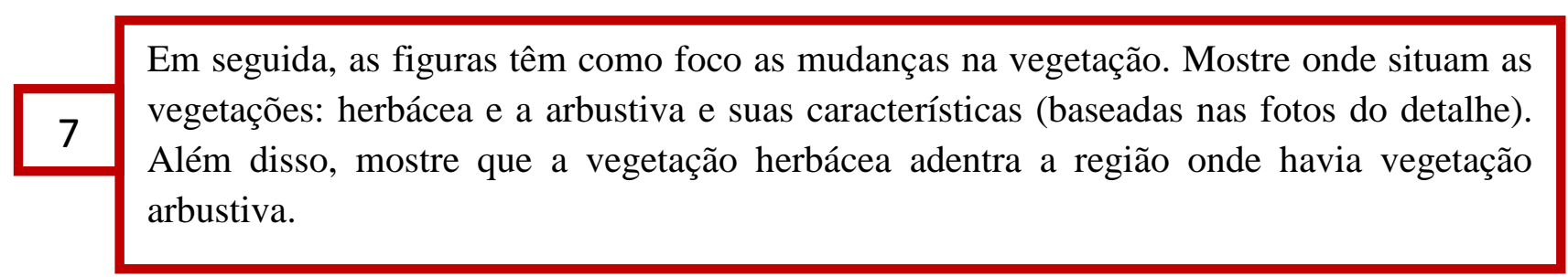

Agora observe o que acontece com a vegetação:
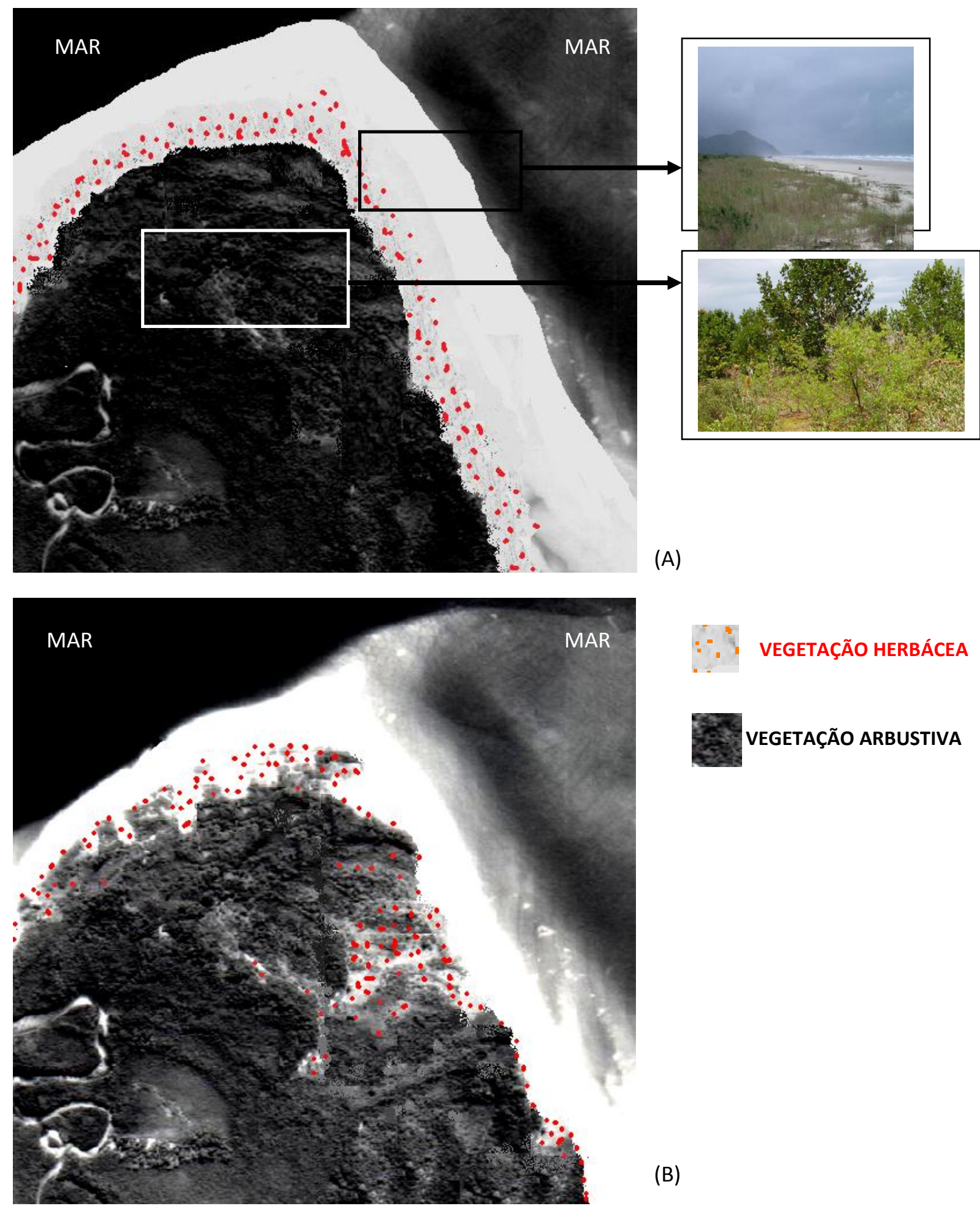

(B) 
Perceba que antes, a vegetação herbácea predominava na faixa da praia beirando a vegetação arbustiva (A). Com a aproximação do mar (B) a vegetação herbácea começou a adentrar e aparecer com mais frequencia nas regiões onde antes a vegetação arbustiva era mais concentrada.

Não havendo dúvidas quanto às imagens, peça que os alunos desenvolvam um texto escrito respondendo às questões. Explique que eles deverão utilizar o texto de apoio grifando as principais informações que julgam ajudá-los a responder a essas questões.

8 Não esqueça! É importante que grifem! Assim, em termos de pesquisa, buscaremos entender de que maneira o aluno compreende o texto descritivo e como ele o utiliza no desenvolvimento das suas explicações.

Agora, com base no material de apoio, responda: 7 Por que, com a aproximação do mar, a vegetação herbácea começou a aparecer
com mais freqüiência onde antes predominava a vegetação arbustiva?

\section{Como se deu esse processo?}

Finalizando, verifique quantos alunos mudaram de opinião comparando-se as respostas da atividade (1) e (2). Discuta com os alunos conduzindo a uma explicação mais viável para o problema. É importante que fique claro que essa não é uma situação verídica e que nem mesmo pode ser considerada uma resposta definitiva, pois existem outros diversos fatores que podem influenciar na dinâmica de um ecossistema, e que, além disso, o problema não partiu de nenhuma pesquisa científica.

Explicação do problema: com a elevação do nível do mar, provavelmente algumas características físicas do ambiente foram se modificando. Fatores como a alta salinidade, a disponibilidade de água, a ação do vento, movimentação da areia e atrito começaram a influenciar diretamente na vegetação arbustiva devido à ausência de estruturas adaptativas como, ao contrário, possuem as herbáceas. Dessa forma, a sobrevivência das plantas arbustivas é comprometida. Ao morrerem são abertas clareiras que modificam as condições do solo (umidade, aderência, incidência direta do sol) e assim torna difícil a instalação de outras espécies arbustivas no lugar. Assim, a vegetação herbácea que possui determinadas estruturas adaptativas para essas condições, se fixam nessas regiões onde antes haviam arbustos. 


\section{Expectativa de resposta do aluno:}

\section{Por que?}

A vegetação herbácea adentrou regiões onde antes predominava vegetação arbustiva porque a elevação do nível do mar modificou as condições físicas do ambiente.

A vegetação herbácea adentrou regiões onde antes predominava vegetação arbustiva porque a vegetação arbustiva foi afetada devido às condições que a ação do mar passou a exercer devido à sua aproximação.

A vegetação herbácea adentrou regiões onde antes predominava vegetação arbustiva porque a vegetação arbustiva não possui as mesmas características das plantas herbáceas que as permitem sobreviver mais próximas ao mar.

\section{Como?}

Com a elevação do nível do mar, a região onde haviam plantas arbustivas ficaram mais próximas da ação do mar. Como elas não possuem as mesmas características que possibilitam a vegetação herbácea sobreviver nessas condições, as plantas morrem e então são ocupadas pelas herbáceas que possuem condições para se fixar e se reproduzir rapidamente.

\section{Os passos desta sequencia foram elaborados a partir do seguinte formato:}

\section{Elaboração de um problema a ser resolvido pelo aluno.}

Consideramos importante para o desenvolvimento desse problema, uma situação que envolvesse um assunto debatido na sociedade atual: a elevação do nível do mar e suas consequências. Dessa forma, aproximamos o aluno de questões que estão na mídia e além disso, envolvemos discussões no âmbito da ciência que não estão totalmente distantes da realidade desses alunos.

\section{Conhecimento prévio: levantamento de hipóteses}

Após a introdução do problema, é elaborado um exercício em que o aluno defende um ponto de vista baseado em seus conhecimentos prévios. Ao final da sequencia didática, o professor retoma esse exercício e verifica se houve mudanças dessas concepções iniciais dos alunos.

\section{A observação}

Nesta etapa, o aluno terá em mãos uma sequencia de figuras (dados) que corroboram uma das hipóteses propostas anteriormente.

\section{A argumentação}

O aluno, então, será desafiado a dar explicações a respeito da situação fornecida. Nessa fase, o aluno contará com um texto de apoio que fornecerá bases teóricas para a resolução da questão. 


\section{A discussão}

Finalizando a sequencia didática, o professor retomará as primeiras considerações feitas pelos alunos, verificando (avaliando) se houve mudanças de concepções ou então, o quanto as explicações tornaram-se mas completas e com conteúdo científico. Além disso, o professor deverá verificar se existem dúvidas e direcionar as discussões delineando o conteúdo proposto. 


\section{APÊNDICE 3 - TRANSCRIÇÃO DA PREPARAÇÃO: MEDIADOR-PROFESSORA}

\begin{tabular}{|c|c|c|}
\hline TURNO & SUJEITO & FALA \\
\hline 1 & ME & $\begin{array}{l}\text { bom Pr então... eu vô fazê a leitura tá do roteiro de orientações da sequência } \\
\text { didática... caso você tenha alguma pergunta você pode me interromper em } \\
\text { qualquer momento...é... fazer as adequações que você quiser e a gente discute } \\
\text { segundo os objetivos da sequência...tá?...então você vai aplicar a sequência } \\
\text { didática e a minha função aqui como mediador é passar as informações em } \\
\text { relação à sequência...e você pode dar qualquer opinião...qualquer adequação } \\
\text { que você quiser contanto que...eu vô fazê a leitura dos objetivos e a gente não } \\
\text { fuja dos objetivos da sequência }\end{array}$ \\
\hline 2 & $\mathbf{P R}$ & ok \\
\hline 3 & ME & $\begin{array}{l}\text { tá bom? então tá...o "desenvolvimento da sequência didática...objetivo central é } \\
\text { que, a partir de um problema, os alunos possam elaborar textos escritos } \\
\text { argumentativos tendo como base a leitura de um texto descritivo em que é } \\
\text { tratada relações entre fatores abióticos e estruturas adaptativas de plantas da } \\
\text { Restinga...tá? }\end{array}$ \\
\hline 4 & PR & ok \\
\hline 5 & ME & $\begin{array}{l}\text { “o conteúdo a ser ensinado...na restinga a proximidade do mar atua como } \\
\text { fator fortemente seletivo para a instalação e crescimento da vegetação...as } \\
\text { plantas são sujeitas a...ventos fortes carregados de partículas de } \\
\text { sal...luminosidade excessiva... escassez de nutrientes...grande instabilidade e } \\
\text { reduzida disponibilidade de água devido à alta permealidade dos terrenos } \\
\text { arenosos...conforme se distancia do mar...observa-se que há modificações na } \\
\text { vegetação as quais refletem as condições do solo que tornam-se mais } \\
\text { estáveis...firmes...com menor permeabilidade e maior disponibilidade de } \\
\text { nutrientes....as fisionomias tornam-se mais complexas a medida que estão mais } \\
\text { distantes do mar”...então esse é o conteúdo...tá? }\end{array}$ \\
\hline 6 & $\mathbf{P R}$ & tá \\
\hline 7 & ME & $\begin{array}{l}\text { mas o objetivo é trazer um problema e aí promover aí...é....a elaboração de } \\
\text { textos argumentativos escritos a partir desse conteúdo...tá?então...agora a } \\
\text { gente vai descrever a sequência didática passo a passo...e aí a primeira coisa } \\
\text { que eu vô pedir pra você é pegar a atividade um }\end{array}$ \\
\hline 8 & PR & tá aqui \\
\hline 9 & ME & $\begin{array}{l}\text { isso...é essa que tem um trecho do jornal da ciência...tá...é...traz aí dados } \\
\text { referentes à elevação do nível do mar... }\end{array}$ \\
\hline 10 & PR & tá \\
\hline 11 & ME & $\begin{array}{l}\text { é suas conseqüências para cidades litorâneas...esse texto aqui o objetivo dele é } \\
\text { aproximar os estudantes das questões colocadas pela mídia...né da } \\
\text { própria...temática do aquecimento global e as relações da elevação do nível do } \\
\text { mar e a destruição das cidades...então........seria interessante se você pudesse } \\
\text { ler em voz alta e explicar o texto }\end{array}$ \\
\hline 12 & PR & $\operatorname{sim}$ \\
\hline 13 & ME & junto com os alunos \\
\hline 14 & PR & tá ok \\
\hline 15 & ME & $\begin{array}{l}\text { o texto é um trecho bem curtinho que é o seguinte ó... “o avanço do } \\
\text { mar...pesquisa da USP revela que o nível do oceano no Brasil sobe quatro } \\
\text { milímetros por ano...índice é considerado alto e coloca em risco áreas } \\
\text { litorâneas do país...não há dúvida de que o nível do mar tem aumentado } \\
\text { gradativamente no litoral brasileiro...a conclusão consta de estudo realizado } \\
\text { pelo instituto oceanográfico da universidade de são paulo io USP...alerta } \\
\text { significa que o país pode sofrer no futuro com uma das piores consequiências } \\
\text { do aquecimento global a destruição de regiões inteiras localizadas próximo à } \\
\text { costa...as possíveis conseqüências do fenômeno vão da perda da faixa de areia } \\
\text { à destruição de cidades...passando por ressacas mais violentas e inúmeros } \\
\text { outros transtornos....Milton Kampel...especialista do instituto nacional de } \\
\text { pesquisas espaciais...inpe...diz que a elevação do oceano preocupa porque as }\end{array}$ \\
\hline
\end{tabular}




\begin{tabular}{|c|c|c|}
\hline & & $\begin{array}{l}\text { regiões costeiras costumam ter alta densidade populacional...milhões de } \\
\text { pessoas vivem numa faixa entre um metro e cinco metros da linha da costa" }\end{array}$ \\
\hline 16 & $\mathbf{P R}$ & ok \\
\hline 17 & ME & $\begin{array}{l}\text { tudo bem? então esse é o trecho do jornal a ser feita a leitura em voz alta e } \\
\text { após a leitura do texto...é...é....mostrar...é...ele ressalta a ocupação das cidades } \\
\text { litorâneas nessa faixa e pode ser que surja aí nesse caso...uma dúvida que é em } \\
\text { relação a definição de restinga }\end{array}$ \\
\hline 18 & PR & tá \\
\hline 19 & ME & $\begin{array}{l}\text { tá?nesse primeiro momento...a idéia aqui pra proposta é que só diga que é um } \\
\text { local caracteriza...é...a vegetação característica desse local...tá?não } \\
\text { necessitando de maiores detalhes }\end{array}$ \\
\hline 20 & PR & certo \\
\hline 21 & ME & $\begin{array}{l}\text { "e cada vez mais casas e edifícios são construídos ao longo das planícies } \\
\text { litorâneas para abrigar essa quantidade enorme de pessoas...e } \\
\text { consequentemente, a vegetação ali existente a restinga é devastada...hoje em } \\
\text { dia são poucas as restingas ainda preservadas em todo o Brasil"...então a idéia } \\
\text { agora é mostrar duas imagens cê tá vendo a figura um...retinga do estaleiro em } \\
\text { Ubatuba e a figura dois que é a praia de santos...né?santos são Paulo...então a } \\
\text { idéia aqui agora é mostrar aos estudantes o que que é uma restinga } \\
\text { mesmo...né...e a planície que ela ocupa...então é muito importante aqui se você } \\
\text { puder enfatizar a região que a gente tá chamando de planície...mostrando pros } \\
\text { alunos a distância entre a linha do mar e do morro tá?e as diferenças...por } \\
\text { exemplo a vegetação nativa ocupando aqui essa região e na figura }\end{array}$ \\
\hline 22 & $\mathbf{P R}$ & ocupada \\
\hline 23 & ME & exatamente a figura ocupada pela zona urbana...tudo bem até aí? \\
\hline 24 & PR & tudo \\
\hline 25 & ME & tranquilo?tem alguma adequação que cê queria... \\
\hline 26 & PR & não tranquilo... \\
\hline 27 & ME & então \\
\hline 28 & PR & podemos continuar \\
\hline 29 & ME & podemos continuar tá? \\
\hline 30 & PR & tá \\
\hline 31 & ME & $\begin{array}{l}\text { então o que a gente fez na primeira parte foi fazê essa relação entre a elevação } \\
\text { do nível do mar e cidades }\end{array}$ \\
\hline 32 & PR & tá \\
\hline 33 & ME & $\begin{array}{l}\text { e destacamos a divulgação disso lá no jornal na mídia ao contrário de elevação } \\
\text { do nível do mar e vegetação que dificilmente a gente se discute } \\
\text { isso...então...é...talvez aí nesse momento fazer um link dessa idéia...é...entre } \\
\text { essa questão da elevação do nível do mar e a destruição de cidade e o que } \\
\text { possivelmente pode ocorrer numa região onde não tem cidade mas sim uma } \\
\text { restinga preservada }\end{array}$ \\
\hline 34 & PR & tá \\
\hline 35 & ME & $\begin{array}{l}\text { então “ vimos no início da atividade que a elevação do nível do mar está na } \\
\text { maioria das vezes associado à destruição de cidades litorâneas figura três e } \\
\text { constantemente é possível encontrar essas informações nos jornais na televisão } \\
\text { e na internet”...então a figura três aí mostrando }\end{array}$ \\
\hline 36 & PR & uma área devastada \\
\hline 37 & ME & $\begin{array}{l}\text { uma área devastada urbana...tá...então a calçada sendo atingida aí pela } \\
\text { elevação do nível do mar... "Porém, pouco se fala das conseqüências da } \\
\text { elevação do nível do mar nas áreas em que a vegetação ainda é preservada" } \\
\text { então daí lança-se a questão "pense...quais seriam as conseqüências? Será que } \\
\text { a vegetação existente nessas áreas pode ser afetada com a aproximação do } \\
\text { mar?" entendeu a relação? }\end{array}$ \\
\hline 38 & PR & entendi \\
\hline 39 & ME & $\begin{array}{l}\text { então já que o pólo discutido é a questão das cidades...a questão levantada é...e } \\
\text { quais as consequiências?né...se }\end{array}$ \\
\hline
\end{tabular}




\begin{tabular}{|c|c|c|}
\hline 40 & PR & levá essa discussão pra uma área natural...preservada \\
\hline 41 & ME & $\begin{array}{l}\text { isso... a elevação do nível do mar pravegetação em áreas que não estão } \\
\text { ocupadas pela zona urbana...tá....só que antes deles pensarem nessa questão...é } \\
\text { importante que a gente leia o quadro aqui abaixo na sequência que tá escrito } \\
\text { atenção...tá...por que?porque na verdade pode ser que ocorra de uma...de uma } \\
\text { idéia assim de um tsunami ou uma...carga muito grande de água por algum } \\
\text { fenômeno natural que desapareça de uma vez só com toda essa vegetação }\end{array}$ \\
\hline 42 & PR & tá \\
\hline 43 & ME & na verdade a idéia é trabalhar o aumento gradativo \\
\hline 44 & PR & $\operatorname{sim}$ \\
\hline 45 & ME & tudo bem? \\
\hline 46 & PR & tudo \\
\hline 47 & ME & $\begin{array}{l}\text { então até que o quadro atenção tá escrito o seguinte... "É claro que se o volume } \\
\text { das águas do mar subisse de uma só vez e cobrisse toda a planície } \\
\text { litorânea...toda Restinga iria por água a baixo e deixaria de existir mas estamos } \\
\text { falando de um aumento no nível do mar que ocorre aos poucos, diminuindo a } \\
\text { faixa de areia entre a vegetação e o mar ou seja o mar vai se aproximando da } \\
\text { vegetação mas não chega a cobri-la de uma vez"...então esse é o contexto do } \\
\text { problema colocado tá }\end{array}$ \\
\hline 48 & PR & tá \\
\hline 49 & ME & $\begin{array}{l}\text { ahh...quando ficar bem claro esse problema e o contexto do qual você tá } \\
\text { falando...é interessante que seja lançada duas possíveis hipóteses para que eles } \\
\text { completem e eles escolham }\end{array}$ \\
\hline 50 & PR & tá \\
\hline 51 & ME & $\begin{array}{l}\text { então é a seguinte questão... “dessa forma você acredita que com a } \\
\text { aproximação do mar em áreas preservadas...um....a vegetação não é afetada } \\
\text { pois... }\end{array}$ \\
\hline 52 & PR & completa \\
\hline 53 & ME & $\begin{array}{l}\text { aí eles precisam completar... se a aproximação do mar não afeta a } \\
\text { vegetação...então... esperamos que... e aí eles completam....a afirmativa dois...a } \\
\text { hipótese dois é a vegetação pode ser afetada...pois...e aí eles explicam...ou se a } \\
\text { aproximação do mar afeta a vegetação então esperamos que...aí eles } \\
\text { completam }\end{array}$ \\
\hline 54 & PR & ok \\
\hline 55 & ME & até aí tudo bem?se tiver alguma sugestão...alguma coisa cê pode...interromper \\
\hline 56 & PR & ok \\
\hline 57 & ME & $\begin{array}{l}\text { então... "explique aos alunos que as hipóteses levantadas da atividade anterior } \\
\text { serão discutidas no fim de toda a sequência"...então eles vão fazer a } \\
\text { hipótese...construir a hipótese e isso vai ser discutido no final de toda a } \\
\text { sequência... "entregue a atividade dois para os alunos e diga que veremos o } \\
\text { que poderia acontecer com a elevação do nível do mar em regiões de restinga } \\
\text { preservada"...então a atividade dois agora vai explorar essa situação... } \\
\text { "explique o detalhe das ampliações do mapa e que as fotos da figura } 2 \text { são } \\
\text { vistas de cima de um ponto da Ilha do Cardoso...mostre também a sua } \\
\text { localização...mostre a diferença entre a largura da faixa de praia da figura um e } \\
\text { dois evidenciando a elevação do nível do mar" então aqui só deixar claro pra } \\
\text { eles e você enfatizar que nessas figuras você tem uma diferença de escala } \\
\text { cartográfica dos mapas...então quer dizer tem uma primeira imagem da } \\
\text { américa latina enfatizando o brasil...enfatiza-se o estado de são paulo...você } \\
\text { mostra essa ênfase...no estado de sâo paulo está marcado a região onde está a } \\
\text { ilha do cardoso isso é ampliado...a ampliação da ilha mostra essa região da ilha } \\
\text { e aí sim a região da ilha que são essas duas regiões...desculpa...a região da ilha } \\
\text { onde você tem a imagem antes dum... }\end{array}$ \\
\hline 58 & PR & elevação \\
\hline 59 & ME & isso... \\
\hline 60 & PR & antes e depois de quinze anos \\
\hline 61 & ME & $\begin{array}{l}\text { perfeito...então antes da elevação do nível do mar e depois da elevação do } \\
\text { nível do mar...né...e aí é importante ressaltar pra eles nesse momento focar na }\end{array}$ \\
\hline
\end{tabular}




\begin{tabular}{|c|c|c|}
\hline & & figura na imagem a diferença na faixa de areia cê consegue perceber aí? \\
\hline 62 & PR & antes era maior depois ficou menor...mais estreito \\
\hline 63 & ME & mais estreito então é visível...né? \\
\hline 64 & PR & visível \\
\hline 65 & ME & $\begin{array}{l}\text { que ficou mais estreito quinze anos depois da aproximação do nível do } \\
\text { mar...então a figura A apresenta a faixa da praia mais estreita que a figura B } \\
\text { caracterizando elevação do nível do mar na região no decorrer desses } 15 \\
\text { anos...tá...tudo bem? }\end{array}$ \\
\hline 66 & PR & $\begin{array}{l}\text { figura } \mathrm{A} \text { apresenta a faixa da praia mais estreita que a figura B?tá trocado não } \\
\text { é?a figura B apresenta faixa }\end{array}$ \\
\hline 67 & ME & isso \\
\hline 68 & PR & tem que corrigir né? \\
\hline 69 & ME & tem...tá certo...é isso mesmo...Pr \\
\hline 70 & PR & e a B que é mais estreita \\
\hline 71 & ME & a figura $\mathrm{B}$ apresenta a faixa de areia mais estreita \\
\hline 72 & PR & isso \\
\hline 73 & ME & $\begin{array}{l}\text { do que a A caracterizando a elevação do nível do mar na região no decorrer } \\
\text { desses quinze anos }\end{array}$ \\
\hline 74 & PR & ok \\
\hline 75 & ME & $\begin{array}{l}\text { perfeito...é isso mesmo...bem observado... "em seguida...as figuras têm como } \\
\text { foco as mudanças na vegetação agora...mostre onde situam as vegetações: } \\
\text { herbácea e a arbustiva e suas características baseadas nas fotos do detalhe além } \\
\text { disso...mostre que a vegetação herbácea adentra a região onde havia vegetação } \\
\text { arbustiva...vê se você consegue identificar que na primeira imagem...os pontos } \\
\text { vermelhos }\end{array}$ \\
\hline 76 & PR & representam a vegetação arbustiva \\
\hline 77 & ME & representam a vegetação herbácea \\
\hline 78 & PR & herbácea...verdade \\
\hline 79 & ME & exatamente e a regiãoverde escura...é onde você tem a vegetação arbustiva \\
\hline 80 & PR & $\operatorname{sim}$ \\
\hline 81 & ME & $\begin{array}{l}\text { então na imagem aqui ao lado você tem dois quadros mostrando exatamente a } \\
\text { fisionomia de uma região arbustiva em baixo e da herbácea em cima... }\end{array}$ \\
\hline 82 & PR & ok \\
\hline 83 & ME & $\begin{array}{l}\text { e importante porque como o mapa é uma representação você mostrar como é } \\
\text { exatamente...agora veja em baixo o que acontece.... vegetação arbustiva ela } \\
\text { começa a ter algumas lacunas nessas regiões como você vê na figura }\end{array}$ \\
\hline 84 & PR & deu pra perceber \\
\hline 85 & ME & $\begin{array}{l}\text { então... "perceba que antes a vegetação herbácea predominava na faixa da } \\
\text { praia beirando a vegetação arbustiva...A...com a aproximação do mar em B a } \\
\text { vegetação herbácea começou a adentrar e aparecer com mais frequência nas } \\
\text { regiões onde antes a vegetação arbustiva era mais concentrada...quer dizer...a } \\
\text { figura B é a mesma figura que mostra quinze anos depois quando o mar } \\
\text { avançou }\end{array}$ \\
\hline 86 & PR & certo \\
\hline 87 & ME & $\begin{array}{l}\text { tudo bem? "não havendo dúvidas quanto às imagens... aí você vai pedir pros } \\
\text { alunos desenvolve um texto a partir disso... um texto escrito... tá? respondendo } \\
\text { às questões explique que eles deverão utilizar o texto de apoio grifando as } \\
\text { principais informações que julgam ajudá-los a responder a essas questões não } \\
\text { esqueça é importante que grifem assim em termos de pesquisa buscaremo } \\
\text { entender de que maneira o aluno compreende o texto descritivo e como ele o } \\
\text { utiliza no desenvolvimento das suas explicações }\end{array}$ \\
\hline 88 & PR & ok \\
\hline 89 & ME & $\begin{array}{l}\text { então esse aqui é um texto de apoio...tá ...o material de apoio...quando ele } \\
\text { receber o texto de apoio ele tem uma questão pra responder que é aquela } \\
\text { questão problema...ele vai ler o texto de apoio e você peça assim...olha...os } \\
\text { textos...os trechos que forem importantes pra... }\end{array}$ \\
\hline 90 & PR & você grifa \\
\hline
\end{tabular}




\begin{tabular}{|c|c|c|}
\hline 91 & ME & você grifa pra mim \\
\hline 92 & PR & pra resolução do problema \\
\hline 93 & ME & $\begin{array}{l}\text { não é o que for importante assim...pra ele fazer o resumo como tá acostumado } \\
\text { a fazer...mas o que for importante pra resolução do problema }\end{array}$ \\
\hline 94 & PR & ok \\
\hline 95 & ME & cê acha que tá tudo bem essa parte?eles fariam? \\
\hline 96 & PR & tranqüilo \\
\hline 97 & ME & $\begin{array}{l}\text { depois também dá uma olhada no texto de apoio pra vê se você acha adequado } \\
\text { pra turma...tá...dá uma olhada que você pode sugerir adequações }\end{array}$ \\
\hline 98 & PR & tá \\
\hline 99 & ME & $\begin{array}{l}\text { "agora, com base no material de apoio responda...por que, com a aproximação } \\
\text { do mar a vegetação herbácea começou a aparecer com mais frequência onde } \\
\text { antes predominava a vegetação arbustiva? Como se deu esse processo?" sabe a } \\
\text { imagem mostrando... o avanço? }\end{array}$ \\
\hline 100 & PR & $\begin{array}{l}\text { sim...por que um lugar que a gente não tinha uma vegetação agora a gente } \\
\text { tem...né...é isso }\end{array}$ \\
\hline 101 & ME & $\begin{array}{l}\text { e...exatamente na imagem que ocorreu o aumento do nível do mar...você } \\
\text { houve...houve uma mudança na ocupação da vegetação...como ele explica } \\
\text { isso?tá? }\end{array}$ \\
\hline 102 & PR & tá \\
\hline 103 & ME & $\begin{array}{l}\text { o texto de apoio que você tem é um texto descritivo...né....então ele vai usar as } \\
\text { informações de acordo com o que ele achar importante }\end{array}$ \\
\hline 104 & PR & $\begin{array}{l}\text { e aqui sim...nesse texto vai tá a definição de restinga...e tudo mais que antes eu } \\
\text { não tinha definido alí no começo... }\end{array}$ \\
\hline 105 & ME & $\begin{array}{l}\text { exatamente...não define no começo porque agora no texto ele vai t e } \\
\text { informações...ele não acha no texto...e uma coisa que talvez você possa } \\
\text { conversar com eles...um lugar onde ele acha uma resposta... }\end{array}$ \\
\hline 106 & $\mathbf{P R}$ & tá \\
\hline 107 & ME & $\begin{array}{l}\text { na verdade ele tem que construir um texto argumentativo...ele vai usar as } \\
\text { informações pra construir o texto dele }\end{array}$ \\
\hline 108 & $\mathbf{P R}$ & sim...ele não vai achar no texto isso \\
\hline 109 & ME & uma resposta pronta \\
\hline 110 & $\mathbf{P R}$ & tá \\
\hline 111 & ME & $\begin{array}{l}\text { finalizando verifique quantos alunos mudaram de opinião comparando-se as } \\
\text { respostas da atividade um e dois...lembraas duas hipóteses? }\end{array}$ \\
\hline 112 & $\mathbf{P R}$ & as perguntas...se alteravam ou não a vegetação \\
\hline 113 & ME & $\begin{array}{l}\text { sim...exatamente...ele deu aquela...ele completou fez aquelas duas hipóteses... } \\
\text { "discuta com os alunos conduzindo a uma explicação mais viável para o } \\
\text { problema é importante que fique claro que essa não é uma situação verídica e } \\
\text { que nem mesmo pode ser considerada uma resposta definitiva pois existem } \\
\text { outros diversos fatores que podem influenciar na dinâmica de um ecossistema } \\
\text { e que além disso o problema não partiu de nenhuma pesquisa científica"...né? } \\
\text { assim só elucidar pra eles que é uma situação...é...que foi construída não é } \\
\text { real...não é o único fator que determina as mudanças de um ecossistema }\end{array}$ \\
\hline 114 & $\mathbf{P R}$ & $\operatorname{sim}$ \\
\hline 115 & ME & deixá claro que é uma atividade didática \\
\hline 116 & PR & que tem outras variáveis \\
\hline 117 & ME & isso \\
\hline 118 & PR & não só uma...é que a gente só trabalhando uma \\
\hline 119 & ME & $\begin{array}{l}\text { tudo bem até aí também?...então é nesse momento que a gente retoma as duas } \\
\text { hipóteses que eles colocaram...que que mudou...quem mudou...por que } \\
\text { mudou...tá?só pra você ter clareza...a explicação do problema...que que seria a } \\
\text { expectativa sobre a explicação do problema }\end{array}$ \\
\hline 120 & PR & $\operatorname{sim}$ \\
\hline 121 & ME & $\begin{array}{l}\text { "com a elevação do nível do mar provavelmente algumas características físicas } \\
\text { do ambiente foram se modificando...fatores como a alta salinidade a } \\
\text { disponibilidade de água a ação do vento movimentação da areia e atrito }\end{array}$ \\
\hline
\end{tabular}




\begin{tabular}{|c|c|c|}
\hline & & $\begin{array}{l}\text { começaram a influenciar diretamente na vegetação arbustiva devido à ausência } \\
\text { de estruturas adaptativas como ao contrário possuem as herbáceas dessa } \\
\text { forma...a sobrevivência das plantas arbustivas é comprometida ao morrerem } \\
\text { são abertas clareiras que modificam as condições do solo umidade... } \\
\text { aderência... incidência direta do sol e assim torna difícil a instalação de outras } \\
\text { espécies arbustivas no lugar...assim a vegetação herbácea que possui } \\
\text { determinadas estruturas adaptativas para essas condições se fixam nessas } \\
\text { regiões onde antes haviam arbustos". }\end{array}$ \\
\hline 122 & $\mathbf{P R}$ & $\operatorname{sim}$ \\
\hline 123 & ME & certo? \\
\hline 124 & PR & certo \\
\hline 125 & ME & $\begin{array}{l}\text { tranquilo?expectativa de resposta do aluno agora...aí você vê se você acha que } \\
\text { tá muito distante...se você esperaria essas mesmas respostas ou não... } \\
\text { "porque"...então ó... "a vegetação herbácea adentrou regiões onde antes } \\
\text { predominava vegetação arbustiva porque a elevação do nível do mar } \\
\text { modificou as condições físicas do ambiente" ou "a vegetação herbácea } \\
\text { adentrou regiões onde antes predominava vegetação arbustiva porque a } \\
\text { vegetação arbustiva foi afetada devido às condições que a ação do mar passou } \\
\text { a exercer devido à sua aproximação" ou "a vegetação herbácea adentrou } \\
\text { regiões onde antes predominava vegetação arbustiva porque a vegetação } \\
\text { arbustiva não possui as mesmas características das plantas herbáceas que as } \\
\text { permitem sobreviver mais próximas ao mar"... "como?" a pergunta como... } \\
\text { "com a elevação do nível do mar a região onde haviam plantas arbustivas } \\
\text { ficaram mais próximas da ação do mar...como elas não possuem as mesmas } \\
\text { características que possibilitam a vegetação herbácea sobreviver nessas } \\
\text { condições as plantas morrem e então são ocupadas pelas herbáceas que } \\
\text { possuem condições para se fixar e se reproduzir rapidamente" }\end{array}$ \\
\hline 126 & $\mathbf{P R}$ & ok \\
\hline 127 & ME & $\begin{array}{l}\text { tá?então...é....isso aqui são expectativas...né dando todos os dados o texto de } \\
\text { apoio...ãh...as atividades que foram trabalhadas que ele chegue a essas } \\
\text { conclusões...a essas argumentações }\end{array}$ \\
\hline 128 & $\mathbf{P R}$ & tá \\
\hline 129 & ME & $\begin{array}{l}\text { mas isso sãoexpectativas...né...isso não quer dizer que eles tem que falar isso } \\
\text { pra te dado certo pra você...você vai conduzir a sequência...só foi colocado } \\
\text { aqui pra você te uma idéia das expectativas }\end{array}$ \\
\hline 130 & PR & $\operatorname{sim}$ \\
\hline 131 & ME & $\begin{array}{l}\text { não que você tenha que induzir ou forçar pra que ele diga isso...você tem que } \\
\text { colocar a situação e mediar a situação }\end{array}$ \\
\hline 132 & PR & ele que tem que tirar essas colclusões \\
\hline 133 & ME & $\begin{array}{l}\text { ele que chegue...ô PR mas e se ele chegar em outras conclusões?são } \\
\text { conclusões }\end{array}$ \\
\hline 134 & PR & $\operatorname{sim}$ \\
\hline 135 & ME & $\begin{array}{l}\text { ele pode chegar com quais conclusões que ele achar que deve com base nos } \\
\text { dados...caso ele esteje chegando a conclusões sem fundamentação nos dados } \\
\text { oferecidos aqui o que que você pode fazer é reforçar os dados...olha....mas qual } \\
\text { é a relação da planta herbácea com o ambiente que ela vive?porque de repente } \\
\text { ele não tá considerando esse dado...mas isso numa forma de mediar...é ele que } \\
\text { tem que chegar nas conclusões dele }\end{array}$ \\
\hline 136 & PR & tá \\
\hline 137 & ME & $\begin{array}{l}\text { "os passos desta sequencia didática foram elaborados a partir do seguinte } \\
\text { formato...um...elaboração de um problema a ser resolvido pelo aluno...então o } \\
\text { resumo da sequência agora...então o primeiro passo elaborou o seu problema } \\
\text { pra ser resolvido...consideramos importante para o desenvolvimento desse } \\
\text { problema uma situação que envolvesse um assunto debatido na sociedade } \\
\text { atual...a elevação do nível do mar e suas consequências...dessa forma } \\
\text { aproximamos o aluno de questões que estão na mídia e além disso envolvemos } \\
\text { discussões no âmbito da ciência que não são totalmente distantes da realidade } \\
\text { desses alunos"...o primeiro...premissa é essa... }\end{array}$ \\
\hline
\end{tabular}




\begin{tabular}{|c|c|c|}
\hline 138 & PR & tá \\
\hline 139 & ME & $\begin{array}{l}\text { "segundo passo...conhecimento prévio...levantamento de hipóteses...após a } \\
\text { introdução do problema é elaborado um exercício em que o aluno defende um } \\
\text { ponto de vista baseado em seus conhecimentos prévios...ao final da sequencia } \\
\text { didática, o professor retoma esse exercício e verifica se houve mudanças } \\
\text { dessas concepções iniciais dos alunos"...que é aquelas duas hipóteses... }\end{array}$ \\
\hline 140 & PR & $\operatorname{sim}$ \\
\hline 141 & ME & $\begin{array}{l}\text { "a observação nesta etapa o aluno terá em mãos uma sequencia de figuras } \\
\text { dados que corroboram uma das hipóteses propostas anteriormente"...a } \\
\text { argumentação é o quarto ponto... "o aluno não será desafiado a dar explicações } \\
\text { a respeito da situação fornecida"...desculpa... "o aluno então será desafiado a } \\
\text { dar explicações a respeito da situação fornecida nessa fase o aluno contará } \\
\text { com um texto de apoio que fornecerá bases teóricas para a resolução da } \\
\text { questão"...e o quinto passo que é a discussão...o que é essa discussão? } \\
\text { "finalizando a sequencia didática o professor retomará as primeiras } \\
\text { considerações feitas pelos alunos verificando avaliando se houve mudanças de } \\
\text { concepçôes ou então o quanto as explicações tornaram-se mas completas e } \\
\text { com conteúdo científico além disso o professor deverá verificar se existem } \\
\text { dúvidas e direcionar as discussões delineando o conteúdo proposto" }\end{array}$ \\
\hline 142 & PR & tá \\
\hline 143 & ME & então aqui tem uma síntese da sequência \\
\hline 144 & PR & tá \\
\hline 145 & ME & $\begin{array}{l}\text { tá? e é isso PR eu queria saber se dentre esses passos que eu te } \\
\text { expliquei...objetivos...se você tem dúvida }\end{array}$ \\
\hline 146 & PR & não eu não tenho... \\
\hline 147 & ME & que que cê acha \\
\hline 148 & PR & $\begin{array}{l}\text { gostei porque vô tê duas aulas e acho que vô precisar de duas aulas } \\
\text { mesmo...acho que...tem muito conteúdo muita informação pra ser dada em } \\
\text { cinqüenta minutos }\end{array}$ \\
\hline 149 & PR & certo \\
\hline 150 & ME & essa aqui não é uma sequência de cinqüenta minutos \\
\hline 151 & PR & não \\
\hline 152 & ME & não \\
\hline 153 & PR & $\begin{array}{l}\text { pra ler bastante texto...leitura...leitura do material de apoio...a análise da } \\
\text { atividade dois....acho que realmente eu vô precisar de duas aulas }\end{array}$ \\
\hline 154 & ME & cê precisa de duas? \\
\hline 155 & PR & e...eu tenho duas...então vai ser tranquilo...eu tenho a terceira e a quarta \\
\hline 156 & ME & mas em duas você acha que dá? \\
\hline 157 & PR & duas acho que dá \\
\hline 158 & ME & certo \\
\hline 159 & PR & $\begin{array}{l}\text { porque tem que lê tudo e com certeza vão ter dúvidas...interrupções da } \\
\text { aula...né...então acho que precisa de duas aulas mesmo }\end{array}$ \\
\hline 160 & ME & $\begin{array}{l}\text { tem alguma coisa que você modificaria da sequência...que você daria idéias } \\
\text { para...pensando nos teus alunos? }\end{array}$ \\
\hline 161 & PR & $\begin{array}{l}\text { não eu acho que...meu trabalho vai ser...eu vô tê que tê um trabalho de } \\
\text { mediadora muito grande...ler com eles...explicando com calma...porque são } \\
\text { assuntos que eles não...adaptação eles já conhecem agora essa parte de restinga } \\
\text { eles nunca ouviram falar ainda...não tem conhecimento muito } \\
\text { aprofundado...então eu vô aprofundar nessa parte }\end{array}$ \\
\hline 162 & ME & entendi \\
\hline 163 & PR & né porque adaptação eles já aprenderam... \\
\hline 164 & ME & certo \\
\hline 165 & PR & então eles tem o conteúdo de adaptação...eles já sabem \\
\hline 166 & ME & eles já sabem \\
\hline 167 & PR & já sabem...alunos de sétimo ano já conhecem...provavelmente eles vão fazer o \\
\hline
\end{tabular}




\begin{tabular}{|c|c|c|}
\hline & & link...espero que sim também...porque eu já dei o assunto...já falei várias vezes \\
\hline 168 & ME & $\begin{array}{l}\text { então você espera que como você já trabalhou essa ...essa...adaptação você } \\
\text { acha que essa sequência é adequada ao seu grupo }\end{array}$ \\
\hline 169 & PR & $\begin{array}{l}\text { eu acho...eu acho que eles vão fazer o link...ah...porque tá mais } \\
\text { adaptada...entendeu...acho que sim }\end{array}$ \\
\hline 170 & ME & $\begin{array}{l}\text { certo...e você...tem alguma dificuldade assim...você acha que tem alguma } \\
\text { dúvida com relação ao problema ao entendimento do problema...entendimento } \\
\text { da situação problema... }\end{array}$ \\
\hline 171 & PR & não \\
\hline 172 & ME & e da condução da discussão \\
\hline 173 & PR & $\begin{array}{l}\text { não...de modo algum...eu só vô tê que me restringir a não extrapolar dessa } \\
\text { parte...porque eles vão querer discutir muito a parte do avanço do mar nas } \\
\text { cidades litorâneas eu acho que eles vão querer ficar falando ali...e eu tenho que } \\
\text { já...é...direcionar a discussão pra uma área preservada...que é o xis da } \\
\text { questão...que a gente tá tentando analisar o avanço do mar numa área } \\
\text { preservada }\end{array}$ \\
\hline 174 & ME & $\operatorname{sim}$ \\
\hline 175 & PR & $\begin{array}{l}\text { e aí como eles vão primeiro ler um texto sobre a área já ocupada acho que eles } \\
\text { vão querer ficar discutindo muito isso...porque é uma coisa próxima deles...é } \\
\text { uma coisa que realmente tá no noticiário...daí eu vô te que já conduzir a } \\
\text { discussão pra...ó...vamo analisar agora...numa área não ocupada numa área } \\
\text { preservada...que eles gostam disso...é um assunto que chama atenção né... }\end{array}$ \\
\hline 176 & ME & $\begin{array}{l}\text { quer dizer que cê acha que um ponto ali que ce vai te que ter uma atenção é } \\
\text { exatamente naquela transição onde a gente pega o contexto do ambiente } \\
\text { urbano e tenta fazer o link pra questão preservada }\end{array}$ \\
\hline 177 & PR & exato \\
\hline 178 & ME & $\begin{array}{l}\text { então talvez um ponto pra se refletir bastante é aquelas das imagens onde você } \\
\text { tem... }\end{array}$ \\
\hline 179 & PR & e...vamo olhar agora...vamo mudar...vamo analisar \\
\hline 180 & ME & se acontece isso em tal...como é que pode acontecer em tal lugar \\
\hline 181 & PR & $\begin{array}{l}\text { isso...é isso que nós vamos analisar...porque se não eles vão ficar querendo } \\
\text { conversar...ai porque o tsunami no Japão é igual porque é o dia a dia...é o } \\
\text { conhecimento que tem na mídia... }\end{array}$ \\
\hline 182 & ME & $\begin{array}{l}\text { quer dizer...esse é um outro ponto le...assim...legal de observar...que antes de } \\
\text { você permitir a resposta das perguntas você faz essa questão e já coloca } \\
\text { aquela...aquele contexto...ó...não é um tsunami...não é }\end{array}$ \\
\hline 183 & PR & isso...isso mesmo \\
\hline 184 & ME & cê acha que isso também é interessante \\
\hline 185 & PR & é interessante \\
\hline 186 & ME & legal...tá...tem mais alguma observação...mais \\
\hline 187 & PR & não...entendi... \\
\hline 188 & ME & tá tranqüilo... \\
\hline 189 & PR & tá tranqüilo não tenho dúvidas não \\
\hline 190 & ME & então tá certo...então acho que é isso...tá bom? \\
\hline 191 & PR & Brigada \\
\hline
\end{tabular}


APÊNDICE 4 - TRANSCRIÇÃO DA APLICAÇÃO DA SEQUÊNCIA DIDÁTICA

\section{EPISÓDIO 1 - ATIVIDADE 1}

\begin{tabular}{|c|c|c|c|}
\hline TURNO & SUJEITO & FALA & OBS \\
\hline 1 & Pr & então vamo lá...todo mundo com a atividade na mão? & \\
\hline 2 & As & $\operatorname{sim}:: \ldots$ & \\
\hline 3 & Pr & $\begin{array}{l}\text { então vamo vê oh...primeira coisa tem uma reportagem que saiu no jornal da } \\
\text { ciência e a reportagem fala assim oh... "o avanço do mar"... "pesquisa da usp"... } \\
\text { que é a universidade de são paulo... "revela que o nível do oceano no brasil sobe } \\
\text { quatro milímetros por... ano... índice é considerado alto e coloca em risco áreas } \\
\text { litorâneas no país"... assim... "não há dúvida de que o nível do mar tem } \\
\text { aumentado gradativamente"... ou seja, aos poucos, né?... "no litoral brasileiro"... . } \\
\text { a conclusão consta de estudo realizado pelo instituto oceanográfico da } \\
\text { universidade de são paulo...((não faz a leitura das siglas em parênteses: io/usp)) o } \\
\text { alerta significa que o país pode sofrer no futuro com uma das piores } \\
\text { conseqüências do aquecimento global"” que é “a destruição de regiões inteiras } \\
\text { localizadas próximo à...costa...as possíveis conseqüências do fenômeno... vão da } \\
\text { perda da faixa de areia... a destruição de cidades passando por ressacas mais } \\
\text { violentas e inúmeros outros... transtornos...milton kampel especialista do instituto } \\
\text { nacional de pesquisas especi...espaciais... ((não faz a leitura da sigla em } \\
\text { parênteses: inpe)) diz que a elevação do oceano preocupa porque as regiões } \\
\text { costeiras costumam ter alta densidades populacional...milhões de pessoas vivem } \\
\text { numa faixa entre um metro e cinco metros da linha da costa"... que que esse texto } \\
\text { tá falando?... que que essa reportagem tá nos...nos...dizendo?... tá falando o que? } \\
\text { que aos poucos o nível do mar tem...subido...é ou não é? }\end{array}$ & $\begin{array}{l}\text { explica o que é usp: } \\
\text { não há, logo em } \\
\text { seguida, a descrição } \\
\text { da sigla }\end{array}$ \\
\hline 4 & As & 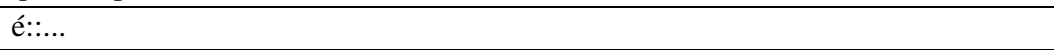 & \\
\hline 5 & Pr & e...ainda tem a conseqüência do que?... do aquecimento... & \\
\hline 6 & As & global::... & \\
\hline 7 & $\mathbf{P r}$ & $\begin{array}{l}\text { então aquele problema climático... que é o aquecimento global...que vocês...sabem } \\
\text { o que é...não sabem? é... tá fazendo com que o mar suba... de pouquinho em } \\
\text { pouquinho... e que isso vai gerar o que pros seres humanos?... uma conseqüência } \\
\text { que é a destruição dessa zona... costeira...essa zona entre o que? o mar...não é? } \\
\text { essa região litorânea...deu pra entender?é isso...então isso é o que?é... essa parte } \\
\text { do texto então tá falando isso... da ação uma conseqüência climática subindo o } \\
\text { mar e atingindo os... humanos... certo?... então aqui a gente tá pensando } \\
\text { numa...numa... numa ação antrópica ou seja pro homem... o nosso problema agora } \\
\text { é vê como isso se dá num ambiente natural ((professora vira a página e os alunos a } \\
\text { seguem)) onde não tem o que? habitantes... porque não são todas as zonas } \\
\text { costeiras que são... habitadas... vira a página... dá uma olhadinha aí... tá vendo } \\
\text { essa restinga do estaleiro ubatuba são paulo?... é a figura um... dá uma olhada na } \\
\text { figura dois...praia de santos...então a figura um... tá sem o que?...habitação...tem } \\
\text { gente aí?tem alguma construção? }\end{array}$ & $\begin{array}{l}\text { leitura do texto da } \\
\text { atividade a professora } \\
\text { vira a página, apenas } \\
\text { segue com a } \\
\text { explicação }\end{array}$ \\
\hline 8 & As & não & \\
\hline \multirow[t]{2}{*}{9} & A3 & só a vegetação & \\
\hline & Pr & $\begin{array}{l}\text { só tem a vegetação isso mesmo...essa vegetação é chamada de restinga...só um } \\
\text { minutinho (...) então essa figura um tá mostrando uma área não habitada... só a } \\
\text { vegetação certo?... e a figura dois? é a mesma área tá vendo?tá vendo as } \\
\text { montanhas lá no fundo? }\end{array}$ & $\begin{array}{l}\text { professora vai atender } \\
\text { a porta }\end{array}$ \\
\hline 10 & A? & uhum & \\
\hline 11 & $\mathbf{P r}$ & $\begin{array}{l}\text { é a mesma área só que agora toda...habitada... a gente viu pelo texto...com as } \\
\text { informações do texto... o que... que essa área habitada com o aumento do mar aos } \\
\text { pouco vai sendo o que?... destruída... e agora nós vamos olhar... e essa } \\
\text { vegetação?...que que vai acontecer com ela?...é esse o nosso problema... com o } \\
\text { aumento do mar o que que vai acontecer com essa vegetação?... vamo virá a } \\
\text { página de novo... óh...... a figura três tá mostrando o que pra gente? uma área } \\
\text { habitada um calçadão... que foi o que? destruído pelo esse avanço do ar... do do } \\
\text { mar... pelo esse... por esse avanço... certo? e agora nós vamos pensar no problema }\end{array}$ & \\
\hline
\end{tabular}




\begin{tabular}{|c|c|c|c|}
\hline & & $\begin{array}{l}\text { agora numa área não habitada... numa área de... vegetação... só que oh... a gente } \\
\text { teve que... é... levar em conta o que?que não é um tsmunami... não é uma onda } \\
\text { gigante que vai vim que levá tudo embora... não é isso... }\end{array}$ & \\
\hline 12 & A? & vai se de pouquinho em pouquinho & \\
\hline 13 & Pr & $\begin{array}{l}\text { é de pouquinho em pouquinho... é uma coisa gradativa... lento... e vai modificar } \\
\text { essa paisagem... ceis acham que vai modificar ou não?vai alterá essa } \\
\text { vegetação?sim ou não? }\end{array}$ & \\
\hline 14 & As & Vai & \\
\hline 15 & Pr & $\begin{array}{l}\text { e é isso que ceis vão responder pra mim agora aqui em um e dois oh... a vegetação } \\
\text { não é afetada pois... o que voceis acham... e se a aproximação do mar não afeta a } \\
\text { vegetação então esperamos que... agora se você não concorda com isso ce vai } \\
\text { responder dois... a vegetação pode ser afetada pois... e o que vocês acharem... e se } \\
\text { a aproximação do mar afeta a vegetação então esperamos que... e é o que vocês } \\
\text { vão responder... tá... então vocês vão ter aí uns seis minutinhos pra... responder... } \\
\text { tá?é o que vocês acham...ceis acham que vai ser afetada sim ou não e se for } \\
\text { afetada o que pode acontecer... certo?... enquanto isso vô fazer a chamada...---- }\end{array}$ & $\begin{array}{l}\text { Professora vai buscar } \\
\text { a lista }\end{array}$ \\
\hline 16 & $\mathbf{P r}$ & número um... pode responder & Início da chamada \\
\hline 17 & A14 & ô pr vai escolher uma das duas pra responder & \\
\hline 18 & Pr & $\begin{array}{l}\text { é... você vai fazer o seguinte ó... cê acha que com o... esse aumento do nível do } \\
\text { mar a vegetação vai ser afetada? se você acha que a vegetação não é afetada você } \\
\text { vai dar uma justificativa e se você acha que ela vai ser afetada você vai dar outra } \\
\text { justificativa... por que que você acha que é afetada. }\end{array}$ & \\
\hline 19 & A3 & tem que escolher uma da outra? & \\
\hline 20 & Pr & isso & \\
\hline 21 & $\mathbf{A 3}$ & ou uma ou outra... não é pra responder as duas & \\
\hline 22 & Pr & $\begin{array}{l}\text { isso... se você... cê acha que a vegetação vai sê ou não afetada com o aumento do } \\
\text { mar? }\end{array}$ & \\
\hline 23 & $\mathbf{A 3}$ & acho que vai & \\
\hline 24 & Pr & então aí você responde a número... dois & \\
\hline 25 & A3 & ahh & \\
\hline 26 & Pr & deu pra entede agora? & \\
\hline 27 & A13 & é só pra gente responder a que concorda & \\
\hline 28 & Pr & exatamente... só a que vocês concordam...número dois... três... quatro... -- -- & chamada \\
\hline 29 & A11 & pr... & levanta a mão \\
\hline 30 & Pr & $\operatorname{sim} . . .()$ & \\
\hline 31 & A11 & ô $\operatorname{pr} . . .()$ & $\begin{array}{l}\text { muitos alunos vão } \\
\text { levantando a mão } \\
\text { chamando pela } \\
\text { professora }\end{array}$ \\
\hline 32 & Pr & ( ) cê acha que vai cê reponde ( ) & \\
\hline 33 & $\mathbf{A 3}$ & assim ó... ( ) pois se elas aqui forem desmatadas aí pode escrever aqui embaixo? & aluna lê a resposta \\
\hline 34 & Pr & pode... pode escrever sim & \\
\hline 35 & $\mathbf{A 2}$ & pr... ( ) assim que é pra fazer? & \\
\hline 36 & Pr & isso... é assim mesmo... certinho & \\
\hline 37 & A1 & pr...é assim né? & \\
\hline 38 & Pr & isso & \\
\hline 39 & A7 & () & \\
\hline 40 & Pr & isso & \\
\hline 41 & A14 & $($ ) & \\
\hline 42 & Pr & ( ) e aí você escreve o que pensa & \\
\hline 43 & A13 & () & \\
\hline 44 & Pr & isso...aí você coloca & \\
\hline 45 & A13 & ( ) & \\
\hline 46 & Pr & () & \\
\hline 47 & A13 & ah tá & \\
\hline
\end{tabular}




\begin{tabular}{|c|c|c|c|}
\hline 48 & Pr & entendeu? & \\
\hline 49 & A16 & $($ ) & \\
\hline 50 & Pr & isso... ce acha que vai acontecê isso... ahã... & \\
\hline 51 & A16 & ( ) & \\
\hline 52 & Pr & $\begin{array}{l}\text { ( ) se a aproximação do mar afeta a vegetação então esperamos que... o que você } \\
\text { espera que vai acontecer com a vegetação? ( ) ce acha que é isso? ( ) então coloca }\end{array}$ & \\
\hline 53 & Pr & $\begin{array}{l}\text { ó... essas perguntas }((\text { dirigindo-se a todos os alunos })) \ldots \text { é a ... é a primeira } \\
\text { pergunta... depois nós vamos discutir tá com... o desenrolar do problema...tá? }\end{array}$ & \\
\hline 54 & A18 & ( ) & \\
\hline 55 & Pr & isso & \\
\hline 56 & $\mathbf{A 1 9}$ & ( ) & \\
\hline 57 & Pr & ( ) ce acha que a vegetação não é afetada...aí justificou... isso que é pra fazer... & \\
\hline 58 & A19 & ( ) & \\
\hline 59 & Pr & $\begin{array}{l}\text { ah ta... é assim...óh... vocês tão com dúvida na... na segunda questão né?... } \\
\text { ((dirigindo a todos os alunos)) se ela é afetada... se você acha que ela vai ser } \\
\text { afetada você vai esperar que aconteça o que com ela? alguma coisa vai acontecer } \\
\text { com ela? que que vocês acham que vai acontecer?agora se vocês acham que ela } \\
\text { não é afetada... alguma coisa acontece com a vegetação... não acontece?... e aí é } \\
\text { pra você justificar... se ela afeta... o que que vocês acham que vai acontecer com } \\
\text { ela? se não afeta o que que vocês acham que pode acontecer com ela?deu pra } \\
\text { entender? }\end{array}$ & \\
\hline 60 & A? & deu & \\
\hline 61 & Pr & oi ( ) & \\
\hline 62 & A24 & assim? ((aponta para a resposta)) & \\
\hline 63 & Pr & isso... isso mesmo ((lê a resposta de A24)) & \\
\hline 64 & $\mathbf{A 2 2}$ & ( ) & $\begin{array}{l}\text { aparentemente aluno } \\
\text { lê a resposta que } \\
\text { escreveu para a } \\
\text { professora }\end{array}$ \\
\hline 65 & Pr & $\begin{array}{l}\text { isso... tá certo... isso mesmo... você falou que sim e já deu a resposta embaixo } \\
\text { entendeu?você fez tudo em uma só mas pode deixar assim }\end{array}$ & \\
\hline 66 & $\mathbf{A 2 5}$ & $($ ) & \\
\hline 67 & Pr & isso... tá certo (( lê a resposta de a) & \\
\hline 68 & A16 & & \\
\hline 69 & Pr & $\begin{array}{l}\text { isso... isso mesmo... é pra falar se sim ou não... não é? e falar o que que vocês } \\
\text { acham que vai acontecer com essa vegetação ((dirigindo-se a todos os alunos)) }\end{array}$ & \\
\hline 70 & $\mathbf{A 3}$ & ( ) & \\
\hline 71 & Pr & ((risos) $)$ & \\
\hline 72 & Pr & oi A2 & \\
\hline 73 & $\mathbf{A 2}$ & aqui óh... coloquei assim óh... é minha opinião né?... & \\
\hline 74 & Pr & ahã & \\
\hline 75 & $\mathbf{A 2}$ & $\begin{array}{l}\text { aí deixa te perguntar outra coisa... é... vai responder as outras... ou não tem } \\
\text { perguntas aqui? }\end{array}$ & \\
\hline 76 & Pr & não não... aqui era só pra mostrar a área & \\
\hline 77 & $\mathbf{A 2}$ & ah tá & \\
\hline 78 & Pr & não é pra fazer nada & \\
\hline 79 & $\mathbf{A 3}$ & $\begin{array}{l}\text { coloquei assim oh... ( ) mas aqui eu já tinha explicado aqui em cima... posso } \\
\text { apagar isso? }\end{array}$ & aluna lê a resposta \\
\hline 80 & Pr & pode & \\
\hline 81 & A11 & $($ ) & \\
\hline 82 & Pr & isso mesmo & \\
\hline 83 & Pr & alguma dúvida ((dirigindo-se a todos os alunos)) & \\
\hline 84 & $\mathbf{A 7}$ & pr & \\
\hline 85 & Pr & $\operatorname{sim}$ & \\
\hline 86 & A7 & $($ ) & \\
\hline 87 & Pr & $\begin{array}{l}\text { isso... é isso mesmo... vocês dêem a sua opinião ((dirigindo-se a todos os alunos)) } \\
\text { se vai ser ou não afetada... tá... e o que pode acontecer com ela }\end{array}$ & \\
\hline 88 & A? & escolher uma das duas? & \\
\hline 89 & Pr & isso... tem que escolher uma das duas & \\
\hline
\end{tabular}




\begin{tabular}{|c|c|c|c|}
\hline 90 & $\mathbf{A 1 3}$ & ( ) & $\begin{array}{l}\text { a professora lê a } \\
\text { resposta }\end{array}$ \\
\hline 91 & Pr & isso agora tá certo... é a sua opinião... depois nós vamos discutir essas opiniões tá? & \\
\hline 92 & Pr & todo mundo respondeu? & \\
\hline 93 & As & $\{\operatorname{sim}\}$ & \\
\hline 94 & Pr & $\begin{array}{l}\text { quem não respondeu?... então nós vamos agora pra atividade dois... deixa essa } \\
\text { questão aí que depois nós vamos o que?... discutir ela e depois vocês vão tê que } \\
\text { me falá se vocês vão mudar ou não de opinião com o desenrolar do problema... tá } \\
\text { certo?... então vamos pra atividade dois agora -- -- }\end{array}$ & entrega do material \\
\hline \multicolumn{2}{|c|}{ EPISÓDIO 2 - ATIVIDADE 2} & \multirow{2}{*}{$\begin{array}{l}\text { vamo lá então...que que nós tínhamos então?nós tínhamos a elevação do nível do } \\
\text { mar...não é?numa área urbana...foi ou não foi?e a gente viu que com essa elevação } \\
\text { as cidades litorâneas vão sendo o que?...destruídas...aí a gente quer saber agora se } \\
\text { numa vegetação natural onde não tem o que?população...não tem nada } \\
\text { construído...não é?se como vai alterar essa vegetação...é esse o nosso problema } \\
\text { não é?e aí ela fez duas perguntas....se ela....se vocês acham que elas vão...que se } \\
\text { essa vegetação vai ser alterada...e como isso pode...que que vai acontecer com } \\
\text { ela...e se a vegetação não vai ser alterada...que que vai acontecer com ela...cada } \\
\text { um tem uma...opinião...é ou não é?e é isso que eu quero mesmo...cada um tem } \\
\text { que tê uma opinião sobre o problema...vamo estudá um pouquinho mais esse } \\
\text { problema...dá uma olhadinha na atividade dois...tá vendo que tem um mapa da } \\
\text { américa do sul? }\end{array}$} & \\
\hline 01 & Pr & & \\
\hline $\mathbf{0 2}$ & A? & uhum & \\
\hline $\mathbf{0 3}$ & Pr & tá vendo? & \\
\hline 04 & As & $\operatorname{sim}$ & \\
\hline 05 & Pr & tá conseguindo ver? & \\
\hline 06 & As & $\operatorname{sim}$ & \\
\hline 07 & Pr & tá vendo que o estado...que estado que é esse que tá em negrito? & \\
\hline 08 & As & são paulo & \\
\hline 09 & & $\begin{array}{l}\text { são paulo...o nosso estado não é?aí...esse estado de são paulo tá vendo que em } \\
\text { cima tem um quadradinho na parte no canto inferior aqui? }\end{array}$ & \\
\hline 10 & A? & tem & \\
\hline 11 & Pr & $\begin{array}{l}\text { tá vendo?esse canto então ele tá ampliado nesse quadrado pra gente poder } \\
\text { enxergar melhor...tá vendo?e esse quadradinho aqui do estado de são paulo é o } \\
\text { que tá ampliado embaixo...tão conseguindo entender? }\end{array}$ & \\
\hline 12 & A? & ahã & \\
\hline 13 & Pr & $\begin{array}{l}\text { sim?e qual que é essa região?essa região é região que fica no sul do estado de são } \\
\text { paulo que é a ilha do...cardoso...tá vendo?e essa região aqui é uma região costeira } \\
\text { que não é habitada...tá?....ao contrário de santos...que tem toda aquelas construções } \\
\text { aqui na ilha do cardoso ainda predomina a vegetação...natural }\end{array}$ & \\
\hline 14 & $\mathbf{A}$ & só tem vegetação? & \\
\hline 15 & Pr & $\begin{array}{l}\text { só tem vegetação...tá vendo?e é essa...é esse lugar que nós vamos analisar } \\
\text { agora...deu pra entender onde a gente tá?então a gente pegou o mapa de são } \\
\text { paulo...selecionamos essa região sul que é a ilha do cardoso ela tá bem ampliada } \\
\text { aqui pra gente pode conseguir enxergar o local e esse quadradinho aqui...tá vendo } \\
\text { na ilha do cardoso?ele tá ampliado aqui em duas formas...ó de duas maneiras...que } \\
\text { é a figura a e a figura b...dá uma olhadinha na figura a...tá vendo a praia? }\end{array}$ & \\
\hline 16 & As & $\{\operatorname{sim}\}$ & \\
\hline 17 & Pr & tá grossa a margem de areia...não tá? & \\
\hline 18 & As & tá & \\
\hline 19 & Pr & $\begin{array}{l}\text { não tá?bem espessa não tá?tem o mar a praia e embaixo da praia a vegetação...tá } \\
\text { bem branca essa faixa não tá? }\end{array}$ & \\
\hline 20 & $\mathbf{A 3}$ & a vegetação é maior & \\
\hline 21 & Pr & a vegetação?e a areia?que que cê acha da areia? & \\
\hline 22 & A2 & também é maior & \\
\hline 23 & A3 & também & \\
\hline 24 & Pr & é maior...é ou não é?...só um minutinho (...) & $\begin{array}{l}\text { interrupção-batem na } \\
\text { porta }\end{array}$ \\
\hline 25 & $\mathbf{P r}$ & $\begin{array}{l}\text { agora dá uma olhadinha na figura b...depois de quinze anos...que foi tendo o } \\
\text { que?a aproximação do mar...dá uma olhadinha...que que aconteceu com a margem }\end{array}$ & \\
\hline
\end{tabular}




\begin{tabular}{|c|c|c|c|}
\hline & & de areia ela di... & \\
\hline 26 & $\mathbf{A 2}$ & mais fina & \\
\hline 27 & A1 & minuiu & \\
\hline 28 & Pr & bastante não é?tá mais estreita...e a vegetação? & \\
\hline 29 & A3 & diminuiu também & \\
\hline 30 & Pr & vamo dá uma olhada na vegetação...oi & \\
\hline 31 & A16 & ( ) afinou e foi algumas lá pro mar não foi? & \\
\hline 32 & Pr & isso vamo vê...vamo ve...ce acha que foi pro mar... & \\
\hline 33 & A16 & é...um pouco & \\
\hline 34 & Pr & é aí por que?a... & \\
\hline 35 & A? & ( ) & \\
\hline 36 & Pr & exatamente porque...o mar tá mais próximo da... & \\
\hline 37 & A2 & areia & \\
\hline 38 & Pr & ele levou um pouco da areia...não tá?a...a margem de areia ficou... & \\
\hline 39 & A2 & fina & \\
\hline 40 & A? & menor & \\
\hline 41 & Pr & fina...não ficou?ficou menor...ele se aproximou da vegetação...não se aproximou? & \\
\hline 42 & A? & $\operatorname{sim}$ & \\
\hline 43 & Pr & sim ou não? & \\
\hline 44 & As & $\{\operatorname{sim}\}$ & \\
\hline 45 & Pr & oi & \\
\hline 46 & A? & e lá também baixou um pouco & \\
\hline 47 & $\mathbf{A 1 1}$ & $\begin{array}{l}\text { pr!e lá também a areia tá se aproximando...é...tá coisando aqui ó na } \\
\text { vegetação...dentro }\end{array}$ & \\
\hline 48 & Pr & $\begin{array}{l}\text { tá?adentrando...ficando...isso!tá mostrando isso na figura...tá claro pra todo } \\
\text { mundo isso?que antes a gente tinha uma configuração...a gente tinha uma margem } \\
\text { de areia bem grande e agora essa...depois de quinze anos com a aproximação do } \\
\text { mar... }\end{array}$ & \\
\hline 49 & A? & o nível do mar diminuiu a areia & \\
\hline 50 & Pr & $\begin{array}{l}\text { a areia...isso mesmo...e agora essa...essa...essa margem de areia é menor...todo } \\
\text { mundo entendeu isso? }\end{array}$ & \\
\hline 51 & As & $\operatorname{sim}$ & \\
\hline 52 & Pr & ótimo...vira a página então... & \\
\hline 53 & $\mathbf{A 3}$ & ( ) a extensão da areia? & \\
\hline 54 & Pr & $\begin{array}{l}\text { isso...diminuiu a espessura de areia...não diminuiu?depois de quinze anos?vamo } \\
\text { vê em relação a vegtação...dá uma olhadinha...tá vendo essas bolinhas vermelhas? }\end{array}$ & \\
\hline 55 & As & $\operatorname{sim}$ & \\
\hline 56 & Pr & $\begin{array}{l}\text { pontilhadas?dá uma olhadinha do lado tem uma legenda né a vegetação } \\
\text { herbácea...e essa parte que tem esse quadrado branco aqui na vegetação é a } \\
\text { vegetação... }\end{array}$ & \\
\hline 57 & As & arbustiva & \\
\hline 58 & Pr & $\begin{array}{l}\text { arbustiva...dá uma olhada...aqui tem duas fotos pra vocês terem um idéia de como } \\
\text { que é a vegetação é...herbácea e como que é a vegetação arbustiva...a vegetação } \\
\text { herbácea é mais rasteira....menor...tá vendo?e a arbustiva um pouco maior...tá } \\
\text { vendo isso?consegue...enxergar?ótimo...depois de quinze anos...olha o que } \\
\text { aconteceu com a vegetação?o pontilhado ele tá o que? }\end{array}$ & \\
\hline 59 & $\mathbf{A 1 3}$ & invadindo a vegetação... arbustiva & \\
\hline 60 & Pr & $\begin{array}{l}\text { perfeito...muito bem...cê tá vendo que essa pontilhada ele tá...invadindo a } \\
\text { vegetação... }\end{array}$ & \\
\hline 61 & As & arbustiva & \\
\hline 62 & Pr & $\begin{array}{l}\text { né...então a gente viu que com a diminuição da espessura de areia a vegetação tá } \\
\text { se modificando não tá?onde a gente tinha uma vegetação herbácea depois } \\
\text { arbustiva a gente agora vê uma vegetação herbácea invadindo a... }\end{array}$ & \\
\hline 63 & As & arbustiva & \\
\hline 64 & $\mathbf{A 1 3}$ & ( ) & \\
\hline 65 & Pr & $\begin{array}{l}\text { e esse é o nosso problema...por que?que condições que nós temos que permite que } \\
\text { a vegetação herbácea que antes ficava delimitada numa faixa...agora invada a } \\
\text { vegetação arbustiva? }\end{array}$ & \\
\hline 66 & A? & aproximação do mar & \\
\hline
\end{tabular}




\begin{tabular}{|c|c|c|c|}
\hline 67 & Pr & oi? & \\
\hline 68 & A? & a aproximação do mar? & \\
\hline 69 & Pr & $\begin{array}{l}\text { a aproximação do mar?é não é?tem a...tem...influencia...a aproximação do mar } \\
\text { agora tá criando o que?condições...não tá?que permita que essa vegetação } \\
\text { herbácea adentre e tome o espaço da vegetação arbustiva }\end{array}$ & \\
\hline 70 & A3 & arbustiva & \\
\hline 71 & & $\begin{array}{l}\text { e o por quê é o que vocês vão ter que responder...é esse o nosso problema...pra } \\
\text { ajudar a gente resolver esse problema a gente tem um texto de apoio que é esse } \\
\text { que tá...que eu entreguei pra vocês...tá escrito material de apoio... }\end{array}$ & \\
\hline 72 & $\mathbf{A 3}$ & ahã & \\
\hline 73 & Pr & tá vendo? & \\
\hline 74 & A? & tô & \\
\hline 75 & Pr & $\begin{array}{l}\text { que que esse material de apoio é?ele é uma caracterização...ele vai explicar como } \\
\text { que é a vegetação da restinga...certo?vamo lê junto pra ajudar a vocês } \\
\text { a...solucionar o problema...olha lá... "conhecendo a restinga....a restinga apresenta } \\
\text { um conjunto diversificado de vegetações que ocupam as } \\
\text { planícies...litorâneas"...lembra daquela figura um lá?da praia até as } \\
\text { montanhas...aquela vegetação rasteira que a gente viu?aquilo é a restinga... "as } \\
\text { vegetações possuem diferentes características a medidas que se distanciam do } \\
\text { mar"... ou seja... do mar até chegar lá na montanha vai tê o que uma...modificação } \\
\text { na vegetação... certo? }\end{array}$ & $\begin{array}{l}\text { la } \\
\text { professora omite } \\
\text { trechos do texto: "que } \\
\text { mudam" }\end{array}$ \\
\hline 76 & As & certo & \\
\hline 77 & Pr & $\begin{array}{l}\text { deu pra entender...uma refusão...refusão é quando... junta... é uma diferenciação } \\
\text { mesmo... plantas mais próximas do mar vai ter uma determinada característica... } \\
\text { plantas mais afastadas do mar vai ter uma... determinada }\end{array}$ & \\
\hline 78 & A? & outra característica & \\
\hline 79 & Pr & é exatamente...outras características & \\
\hline 80 & $\mathbf{A 1 3}$ & ( ) modificá né... o ambiente onde elas se encontram & \\
\hline 81 & Pr & $\begin{array}{l}\text { perfeito isso... deu pra entende?então as características variam de acordo com a } \\
\text { aproximação do mar e o distanciamento do mesmo... certo?nós vamo vê como que } \\
\text { é essa vegetação... "são influenciadas principalmente pelas condições... do solo... } \\
\text { drenagem da água... disponibilidade de nutrientes"... ou seja... a disponibilidade } \\
\text { da água próxima do mar vai ser diferente da disponibilidade mais afastada... } \\
\text { concorda? }\end{array}$ & \\
\hline 82 & As & $\operatorname{sim}$ & \\
\hline 83 & Pr & $\begin{array}{l}\text { e a disponibilidade de nutrientes também e fatores físicos como “ o movimento da } \\
\text { areia... o vento... o atrito do grão de areia... o vento forte... a influência do sol... a } \\
\text { temperatura... a disponibilidade de água... a disponibilidade de sal... a salinidade e } \\
\text { outros... certo?então tudo isso vai interferir o que?nas características da vegetação } \\
\text { que a gente tem mais próximo do mar e que nós temos mais afastadas do mar... } \\
\text { deu pra entender? }\end{array}$ & \\
\hline 84 & As & deu & \\
\hline 85 & Pr & $\begin{array}{l}\text { ótimo... então vamo lá... agora nós vamos fazer uma viagem... descendo do mar } \\
\text { até chegar na planície... vamo vê... ó... "vamos imaginar que acabamos de } \\
\text { desembarcar em uma praia e seguimos em frente em direção a encosta... das } \\
\text { montanhas como indica a seta abaixo"... tá vendo? cê acabou de descer lá na } \\
\text { praia... cê vai chegar lá na montanha... ó... ce vai percorrer esse caminho... vamo } \\
\text { vê passo a passo como que é a vegetação... de quando a gente sai daqui do mar até } \\
\text { chegar na encosta... é isso que nós vamos ver agora... certo? vamo lá... "saindo do } \\
\text { mar... há alguns passos sobre a areia e fora da ação da... das marés nos deparamos } \\
\text { com uma vegetação rasteira... que chega a aproximadamente quarenta centímetros } \\
\text { de altura sobre o chão... são tufos de capim e plan... e plantas de ramos muito } \\
\text { finos e moles que crescem e se reproduzem rapidamente...essa é a vegetação } \\
\text { herbácea"... então essa vegetação é aquela vegetação que nós vimos lá no } \\
\text { problema... lembra?... ((os alunos ficam em silêncio)) tava pontilhada de } \\
\text { vemelha... é a primeira vegetação ao sairmos da praia... mais próximo do mar... } \\
\text { deu pra ver? localizaram ela?... ((silêncio)) certo?então ela é o que?baixinha... }\end{array}$ & \\
\hline
\end{tabular}




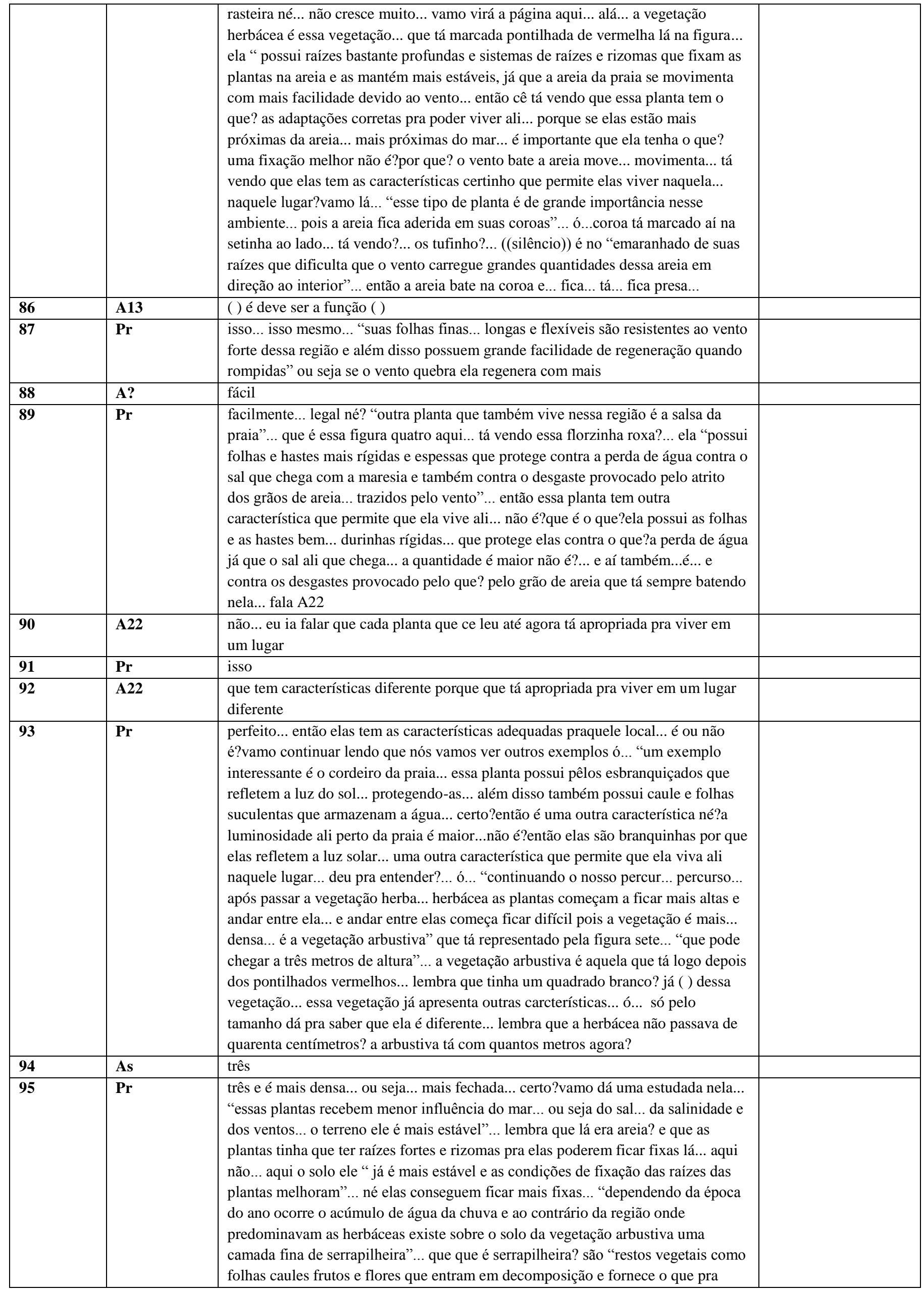




\begin{tabular}{|c|c|c|c|}
\hline & & planta? & \\
\hline 96 & A? & nutriente & \\
\hline 97 & Pr & $\begin{array}{l}\text { nutrientes... né?aí tá a camadinha... nesse quadradinho preto selecionado tá a } \\
\text { acamadinha do que? de serrapilheira... que é essa camada de nutrientes pra essa... } \\
\text { pra essa vegetação... "em seguida continuando o caminho em direção a encosta } \\
\text { das montanhas começam a aparecer árvores que podem chegar até VINTE metros } \\
\text { de altura }\end{array}$ & \\
\hline 98 & As & nossa & \\
\hline 99 & Pr & $\begin{array}{l}\text { olha a diferença... a gente tinha a vegetação de quarenta centímetros e agora nós } \\
\text { vamos ter plantas de quarenta metros de altura... né?e aí já é a floresta de } \\
\text { restinga... tá?’a mata começa a ficar mais fechada e o ambiente é bem mais... } \\
\text { úmido... há grande disponibilidade de nutrientes nessa região em comparação com } \\
\text { as anteriores... aqui podemos perceber que existem muitas espécies de plantas } \\
\text { diferentes e em grande quantidade... o inverso do que ocorre na região das... } \\
\text { praias onde há apenas poucas espécies adaptadas às condições daquele ambiente... } \\
\text { alguma dúvida em relação a vegetação que a gente tá encontrando da hora que a } \\
\text { gente sai do mar até chegar nas montanhas? }\end{array}$ & \\
\hline 100 & As & não & \\
\hline 101 & Pr & $\begin{array}{l}\text { não né?então que que a gente tem?a gente tem uma vegetação primeiro herbácea } \\
\text { depois arbustiva e depois essa floresta de restinga... né?e cada uma apresenta o } \\
\text { que?uma certa característica... então vamo voltá lá pro nosso problema... que que } \\
\text { nós temos?nós temos uma vege... uma... uma aproximação do mar... não } \\
\text { temos?diminuindo essa faixa de areia... não é?se tá diminuindo a faixa de areia } \\
\text { essa aproximação do mar tá chegando mais próximo de quem?da vegetação... não } \\
\text { tá?e aí nós te... tivemos o que? uma modificação na vegetação... antes a vegetação } \\
\text { herbácea que ficava delimitada só a encosta ela agora com a aproximação do mar } \\
\text { tá adentrando não tá?invadindo... exatamente... por que que tá invadindo... que } \\
\text { que ceis acham que tá acontecendo... e aí é o que vocês vão escrever pra mim tá } \\
\text { certo? (...) então vocês vão responder essa pergunta pra mim aqui ó... na última } \\
\text { folha... vô mostrar pra todo mundo pra não ficar perdido.... tá vendo? um e dois?e } \\
\text { aí eles tão fazendo a pergunta que é o seguinte ó... "por que com a aproximação } \\
\text { do mar a vegetação herbácea começa a aparecer com mais frequiência onde antes } \\
\text { predominava a vegetação arbustiva?como se deu esse processo?”... é isso que } \\
\text { vocês tem que responder tá bom?... certo?alguma dúvida? }\end{array}$ & \\
\hline 102 & A6 & posso fazer um esquema... desenha aqui pra responder a um? & \\
\hline 103 & Pr & $\begin{array}{l}\text { ce qué... eu prefiria que você escrevesse... mas... se você quiser escrever e } \\
\text { desenhar... pode sim }\end{array}$ & \\
\hline 104 & $\mathbf{A 1 3}$ & eu não entendi essa dois.. como se deu esse processo & \\
\hline 105 & Pr & $\begin{array}{l}\text { é... por que você acha que a vegetação herbácea foi invadindo... por que que ela } \\
\text { conseguiu invadir?que aconteceu com a vegetação arbustiva?..... cê tá com } \\
\text { dúvida ainda? }\end{array}$ & \\
\hline 106 & $\mathbf{A 1 3}$ & uhum & \\
\hline 107 & Pr & $\begin{array}{l}\text { ó... é assim ó... a aproximação do mar você já falou que ela já altera a vegetação... } \\
\text { não alterou?e a gente viu que a vegetação herbácea começou a invadir a vegetação } \\
\text { arbustiva não foi?aqui eles tão falando assim... por que que você acha... como que } \\
\text { ela conseguiu invadi?o que será que deve tê acontecido com a vegetação } \\
\text { arbustiva... o que será que aconteceu com essa vegetação arbustiva pra que com.. } \\
\text { pra que a vegetação herbácea conseguisse tomar o lugar dela?que ce acha que } \\
\text { aconteceu com ela? }\end{array}$ & \\
\hline 108 & A13 & tá & \\
\hline 109 & Pr & entendeu? & \\
\hline 110 & $\mathbf{A 1 3}$ & entendi & \\
\hline 111 & A? & e a dois? & \\
\hline 112 & $\mathbf{A 2}$ & foi o que ela acabou de explicar & \\
\hline 113 & Pr & $\begin{array}{l}\text { foi isso que eu falei... mas ó... vamo de novo...ó... aqui existia uma vegetação } \\
\text { herbácea... não tinha?que agora depois do avanço do mar a gente viu que ela } \\
\text { começou a invadir o lugar da outra vegetação... a arbustiva... não é?a gente quer } \\
\text { saber o por que ela conseguiu invadir... se ela conseguiu invadir... como ela } \\
\text { conseguiu?por que que ela conseguiu invadir? que que ela fez?que que aconteceu } \\
\text { com a vegetação arbustiva... que que ce acha que aconteceu com a vegetação }\end{array}$ & \\
\hline
\end{tabular}




\begin{tabular}{|c|c|c|c|}
\hline & & arbustiva que cedeu o lugar pra herbácea ocupar o lugar dela? & \\
\hline 114 & A22 & ( ) & \\
\hline 115 & Pr & se você pode falar a resposta?... então fala só pra mim & \\
\hline 116 & A22 & $\begin{array}{l}\text { por que que a herbácea tomou o lugar dela?... por que o nível do mar aumento e é } \\
\text { característica dela viver naquele lugar perto do mar }\end{array}$ & $35: 10$ \\
\hline 117 & Pr & perfeito... isso mesmo... escreve isso pra mim... certinho... & \\
\hline 118 & A3 & não entendi a um & \\
\hline 119 & Pr & $\begin{array}{l}\text { não entendeu a um?... vamo lá de novo ó... por que que... a gente viu que o mar } \\
\text { aproximou... a faixa de areia ficou mais... }\end{array}$ & \\
\hline 120 & A3 & extensa & \\
\hline 121 & Pr & estreita & \\
\hline 122 & A1 & estreita & \\
\hline 123 & Pr & né?... estreita... menor... não é?mais fino... não é?é ou não é? & \\
\hline 124 & A1 & é & \\
\hline 125 & & $\begin{array}{l}\text { e aí a gente viu que aconteceu o que com a vegetação?a vegetação herbácea que } \\
\text { antes ocupava só uma faixinha... ela começou o que?ela começou a... invadir... } \\
\text { não começou?a tomar o lugar da vegetação arbustiva... por que que vocês acham } \\
\text { que isso aconteceu?analisando aquele texto de apoio que a gente leu... que } \\
\text { característica tem a planta herbácea que permitiu que ela adentrasse assim e que } \\
\text { característica tem a arbustiva que permitiu que ela o que?não resistisse aquele } \\
\text { lugar... aque... aquela condição que agora ela tava presenciando?deu pra entender? }\end{array}$ & \\
\hline 126 & A3 & é mais ou menos... & \\
\hline 127 & Pr & $\begin{array}{l}\text { é pra vocês grifarem o texto de apoio... o que que vocês utilizaram pra escrever... } \\
\text { pra responder }\end{array}$ & \\
\hline 128 & $\mathbf{A 1 3}$ & ( ) & aluna pergunta \\
\hline 129 & Pr & ( ) $\operatorname{sim} . .$. pode por & \\
\hline 130 & A2 & $\begin{array}{l}\text { pf... aqui ó... tãnanana ((aluna simula leitura e aponta trecho do texto de apoio)) } \\
\text { pode escrever isso? }\end{array}$ & \\
\hline 131 & Pr & cê tá usando isso pra responder? & \\
\hline 132 & A2 & é & \\
\hline 133 & Pr & então você grifa pra mim só... só que... & \\
\hline 134 & A2 & dá uma... & \\
\hline 135 & Pr & $\begin{array}{l}\text { isso... cê vai grifar pra mim o que que você tá usando pra responder a pergunta, } \\
\text { né?por que com a aproximação do mar a vegetação herbácea começou a invadir } \\
\text { né... o lugar onde predominava a outra... e aí se você usar isso aqui re... ajudar a } \\
\text { formular sua resposta você grifa pra mim }\end{array}$ & \\
\hline 136 & A3 & não tô conseguindo & \\
\hline 137 & $\operatorname{Pr}$ & $\begin{array}{l}\text { não tá conseguindo... vamo lá... o que a gente tinha antes?a gente tinha uma faixa } \\
\text { de areia muito... }\end{array}$ & \\
\hline 138 & A3 & grande & \\
\hline 139 & Pr & E aí o mar veio se aproximando e a faixa de areia ficou... & \\
\hline 140 & A3 & menor & \\
\hline 141 & Pr & menor... é ou não é? & \\
\hline 142 & A3 & é & \\
\hline 143 & Pr & $\begin{array}{l}\text { diminuiu a areia e o que aconteceu com a vegetação... quando a areia era } \\
\text { espessa... grande aqui a vegetação arbustiva ficava localizada aqui não é? bem } \\
\text { próximo do mar... não é?e a vegetação arbustiva tomava esse espaço aqui } \\
\text { certo?quando a diminuição da areia diminuiu... só um minutinho ((outro aluno } \\
\text { chama a professora)) com a diminuição da faixa de areia diminuiu o que } \\
\text { aconteceu com a vegetação arbustiva?ela começou a se... espalhar e a vegetação } \\
\text { arbustiva? }\end{array}$ & \\
\hline 144 & A3 & dominou tudo & \\
\hline 145 & Pr & $\begin{array}{l}\text { a vegeta... essa é a herbácea... não... essa vegetação herbácea começou predominar } \\
\text { tudo... e a vegetação arbustiva?cade ela? }\end{array}$ & $\begin{array}{l}\text { Alunos da frente A1 e } \\
\text { A2 olham para trás } \\
\text { escutando a } \\
\text { explicação da Pr para } \\
\text { A3 }\end{array}$ \\
\hline 146 & A3 & ela sumiu & \\
\hline 147 & Pr & sumiu... pra onde ela foi? & \\
\hline 148 & A1 & foi embora & outro aluno responde \\
\hline
\end{tabular}




\begin{tabular}{|c|c|c|c|}
\hline 149 & $\mathbf{P r}$ & ela já não existe mais onde ela... & \\
\hline 150 & A3 & existia & \\
\hline 151 & Pr & existia & \\
\hline 152 & A2 & ela foi existir em outro lugar... não é & \\
\hline 153 & Pr & $\begin{array}{l}\text { por que com a aproximação do mar essa vegetação começou a ( ) o que propiciou } \\
\text { essa aproximação do mar... que características que propiciou... é... esse avanço } \\
\text { aqui do mar propiciou o que?pra essas vegetação aqui deu condições o que pra } \\
\text { essa vegetação herbácea podê... é... se }\end{array}$ & \\
\hline 154 & $\mathbf{A 1}$ & espalhar & \\
\hline 155 & Pr & expandir... isso... que que ela fez com a vegetação arbustiva? & \\
\hline 156 & A2 & destruiu? & \\
\hline 157 & Pr & quais são as carac & \\
\hline 158 & $\mathbf{A 3}$ & que... é... o mar... fez... não & \\
\hline 159 & Pr & $\begin{array}{l}\text { ó... é... por que que a vegetação herbácea depois que aproximou mais do mar ele } \\
\text { conseguiu o que?ela conseguiu se espalhar?quais são as características das... da... } \\
\text { quais são as características de uma planta herbácea? }\end{array}$ & \\
\hline 160 & A3 & raízes fortes & \\
\hline 161 & Pr & $\begin{array}{l}\text { isso... aí ela consegue viver melhor... não consegue?tá mais próximo do mar... e a } \\
\text { região... e a vegetação arbustiva? }\end{array}$ & \\
\hline 162 & A3 & ela não consegue & \\
\hline 163 & Pr & por que que ela não consegue? & \\
\hline 164 & A1 & por que ela não é forte & \\
\hline 165 & Pr & é forte que fala? & \\
\hline 166 & $\mathbf{A 3}$ & ah não é forte ((aluna procura no texto)) & \\
\hline 167 & Pr & ó... aqui fala da vegetação arbustiva & \\
\hline 168 & $\mathbf{A 3}$ & ( ) ((aluna começa a ler onde aponta a professora)) & \\
\hline 169 & Pr & a arbustiva é preparada pra viver mais próximo do mar? & \\
\hline 170 & $\mathbf{A 3}$ & não... ela vive num lugar mais assim... longe da água & \\
\hline 171 & Pr & $\begin{array}{l}\text { isso... tem características pra poder viver mais longe da água... ela tem } \\
\text { característica pra viver mais perto do mar?por que que cê acha que a vegetação } \\
\text { herbácea começou a invadir a arbustiva? }\end{array}$ & \\
\hline 172 & A3 & porque a... como que chama... a & \\
\hline 173 & Pr & herbácea & \\
\hline 174 & A3 & herbácea ela tem mais predominância de ficar mais perto do mar e essa não & \\
\hline 175 & Pr & escreve aqui pra mim & \\
\hline 176 & Pr & quem me chamou?peraí... só um minutinho... & \\
\hline 177 & A7 & ( ) & toca o sinal \\
\hline 178 & Pr & vamo saí pro intervalo e qdo volta a gente continua escrevendo & \\
\hline
\end{tabular}

\section{EPISÓDIO 3 - ATIVIDADE 2 (RETORNO DO INTERVALO)}

\begin{tabular}{|c|c|c|}
\hline 01 & Pr & $\begin{array}{l}\text { vamo continuar agora a resolver o nosso problema... antes de sair do intervalo o } \\
\text { que que eu tinha deixado pra vocês?a gente tinha que resolver um problema não } \\
\text { é? que problema era esse?a gente tinha o que?a gente tinha uma faixa de areia } \\
\text { bem grossa bem espessa... não é?que depois de quinze anos ficou o que? }\end{array}$ \\
\hline $\mathbf{0 2}$ & A? & menor \\
\hline 03 & Pr & $\begin{array}{l}\text { fina...não foi?pequena...não foi?a vegetação quando essa faixa de areia era bem } \\
\text { grossa ela ocupava uma determinada região... o que tava pontilhada de } \\
\text { vermelho...é ou não é? }\end{array}$ \\
\hline 04 & As & é \\
\hline 05 & Pr & $\begin{array}{l}\text { quando essa vegeta...quando esse...essa camada de areia diminuiu esse } \\
\text { pontilhado vermelho que que ele fez...ele se....alastrou não é?ele ocupou a área } \\
\text { que antes tinha uma vegetação... }\end{array}$ \\
\hline 06 & A? & arbustiva \\
\hline 07 & Pr & $\begin{array}{l}\text { arbustiva...é ou não é?e qual era o problema que a gente tinha pra resolver?por } \\
\text { que que essa vegetação herbácea conseguiu invadir e ocupar o espaço da } \\
\text { vegetação arbustiva?como que elas conseguiram fazer isso?que é a pergunta dois }\end{array}$ \\
\hline
\end{tabular}




\begin{tabular}{|c|c|c|c|}
\hline & & $\begin{array}{l}\text { como se deu esse processo...que que vocês acham?pra gente solucionar o } \\
\text { problema a gente tinha aquele material de apoio lembra?que que era o material } \\
\text { de apoio?era o material que explicava as características da vegetação não } \\
\text { é?desde quando a gente sai do mar...né....até aonde a gente chega nas } \\
\text { montanhas...toda a planície...e nós vimos que essa vegetação foi o que? se mo... }\end{array}$ & \\
\hline 08 & A? & dificando... & \\
\hline 09 & Pr & $\begin{array}{l}\text { modificando...é ou não é?não vai se modificando?conforme ela vai se afastando } \\
\text { do mar...é ou não é?ela vai se alterando tendo características o } \\
\text { que?diferentes...deu pra entender?alguém tá com dúvida pra responder?...então } \\
\text { podem responder }\end{array}$ & \\
\hline 10 & A? & eu tô com pouquinho na dois & \\
\hline 11 & Pr & $\begin{array}{l}\text { na dois?ó...a dois tá falando o seguinte a vegetação herbácea que é aquela do } \\
\text { pontilhado vermelho invadiu...não invadiu?ela tomou o espaço...como que ela } \\
\text { conseguiu tomar esse espaço?que que a vegetação herbácea tem que permite que } \\
\text { quando o mar chegue mais próximo dela que foi o que aconteceu...ela permite o } \\
\text { que...se expandir tomar uma área maior?que que a vegetação arbustiva tem que } \\
\text { não permitiu que ela conseguisse o que ficar ali naquela área?deu pra entender ou } \\
\text { tá com dúvida ainda?...então tá bom...vamo respondê...depois nós vamos discutir }\end{array}$ & \\
\hline 12 & $\mathbf{A 3}$ & $\operatorname{Pr} \ldots$ & \\
\hline 13 & Pr & oi & \\
\hline 14 & $\mathbf{A 3}$ & ( ) espécie....é espécie? & Aluna lê resposta \\
\hline 15 & Pr & $\begin{array}{l}\text { vegetação herbácea.... gente tá falando de vegetação herbácea...a vegetação } \\
\text { herbácea tem várias espécies diferentes...lembra?vê lá no material de apoio... a } \\
\text { gente tinha a salsa da praia o cordeiro da praia... }\end{array}$ & \\
\hline 16 & $\mathbf{A 2}$ & $($ ) & \\
\hline 17 & Pr & herbácea conseguiu invadir a vegetação arbustiva... & \\
\hline 18 & $\mathbf{A 2}$ & a arbustiva foi destruída e ( ) & \\
\hline 19 & Pr & e por que a vegetação arbustiva foi destruída?por que ela não tá mais lá? & batem na porta \\
\hline 20 & $\mathbf{A 2}$ & depois eu te falo... & $\begin{array}{l}\text { A professora se } \\
\text { distancia para atender } \\
\text { a porta }\end{array}$ \\
\hline 21 & A18 & $($ ) & \\
\hline 22 & Pr & $\begin{array}{l}\text { ó a gente tem o mar aqui tá vendo...ele ficou mais próximo aqui...( ) mais } \\
\text { fino....com isso olha o que aconteceu com a vegetação.... vegetação herbácea que } \\
\text { ficava só nessa região ela começou a invadir toda essa vegetação...o que tinha } \\
\text { antes aqui?qual que era a vegetação que tinha antes? }\end{array}$ & \\
\hline 23 & A18 & arbustiva & \\
\hline 24 & Pr & $\begin{array}{l}\text { arbustiva...e agora a gente tem o que?vegetação herbácea no lugar da vegetação } \\
\text { arbustiva...por que que será que essa vegetação herbácea conseguiu tomar o lugar } \\
\text { da vegetação arbustiva? dá uma olhada no material de apoio...quais as } \\
\text { características dessas duas vegetações?a vegetação herbácea agora ela tá mais } \\
\text { próxima do mar não tá?a vegetação arbustiva com a diminuição da espessura da } \\
\text { areia ela ficou mais próxima do mar não ficou? o que será que aconteceu com } \\
\text { ela?ela tá nessa região?só um minutinho... }\end{array}$ & Pr sai da sala \\
\hline 25 & A16 & $($ ) & \\
\hline 26 & Pr & $\begin{array}{l}\text { a dois tá falando assim ó...a gente sabe que a vegetação herbácea começou a } \\
\text { invadir o local que antes era da arbustiva...ele quer saber o por que? }\end{array}$ & \\
\hline 27 & $\mathbf{A 1 4}$ & $($ ) & \\
\hline 28 & Pr & $\begin{array}{l}\text { ó pessoal pensa nas características agora que a gente tem o mar bem mais } \\
\text { próximo com a diminuição da espessura de areia o mar se aproximou mais da } \\
\text { vegetação arbustiva não se aproximou?como que é essa vegetação arbustiva?ela } \\
\text { tem características que permitiam ela ficar mais próxima do mar? né...vamo } \\
\text { pensa nas características... }\end{array}$ & \\
\hline 29 & $\mathbf{A 3}$ & $($ ) & \\
\hline 30 & Pr & $\begin{array}{l}\text { ó...a gente sabe que a aproximação do mar fez com que a vegetação herbácea } \\
\text { invadisse o lugar da arbustiva...é ou não é?como que ela conseguiu invadir? }\end{array}$ & \\
\hline 31 & A3 & onde tá escrito? & \\
\hline 32 & Pr & não não tá escrito...você tem que formular...ce tem que resolver o & \\
\hline
\end{tabular}




\begin{tabular}{|c|c|c|c|}
\hline & & $\begin{array}{l}\text { problema...né...e aqui você tem o material de apoio...pra apoiar você a } \\
\text { responder...gente ((se volta para a sala toda)) vocês não vão achar uma resposta } \\
\text { pronta no texto...né...vocês vão ter que contruir...né...resolver o problema...vocês } \\
\text { vão construir sua resposta com a ajuda do texto certo? }\end{array}$ & \\
\hline 33 & $\mathbf{A 3}$ & () & \\
\hline 34 & Pr & $\begin{array}{l}\text { ó...a gente sabe que a vegetação herbácea... ó...com a espessura bem próxima do } \\
\text { mar ela ficava aqui não ficava?quando essa espessura diminuiu o mar se } \\
\text { aproximou e ela conseguiu invadir e tomar o lugar da vegetação arbustiva...que } \\
\text { característica tem uma planta herbácea?que cara... }\end{array}$ & \\
\hline 35 & $\mathbf{A 3}$ & ela tem as raízes... & \\
\hline 36 & Pr & isso...tem as raízes o que? & \\
\hline 37 & A3 & fortes & \\
\hline 38 & Pr & $\begin{array}{l}\text { que pode fixar...não é?que características tem as plantas arbustivas uma planta } \\
\text { arbustiva com as características que ela tem ela consegue sobreviver num lugar } \\
\text { mais próximo do mar?e a planta herbácea...ela é mais apropriada...ela } \\
\text { consegue?tenta resolver o problema nesse sentido }\end{array}$ & \\
\hline 39 & A? & () & $10: 26$ \\
\hline \multirow[t]{19}{*}{40} & Pr & $($ ) & \\
\hline & Pr & quem terminou?...quem não terminou? & \\
\hline & $\mathbf{A 3}$ & não Pr...vem aqui & \\
\hline & Pr & oi & \\
\hline & A3 & $\begin{array}{l}\text { pr olha... nesse negocinho aqui ó... eu peguei e falei assim ó...coloquei porque a ( } \\
\text { ) arbustiva... }\end{array}$ & $\begin{array}{l}\text { A professora lê a } \\
\text { resposta de A3 }\end{array}$ \\
\hline & Pr & $($ ) & \\
\hline & A3 & não é não & \\
\hline & Pr & arbustiva é também ( ) & \\
\hline & $\mathbf{A 3}$ & não... é essa daqui que eu quero colocar & \\
\hline & Pr & então é herbácea... não é arbustiva & \\
\hline & A3 & ahh & aluna apaga \\
\hline & Pr & quer escrever herbácea? & \\
\hline & A3 & é... é que eu escrevi errado & \\
\hline & Pr & ela escreveu arbustiva com $\mathrm{H}$ & $\begin{array}{l}\text { falando para aluna da } \\
\text { frente }\end{array}$ \\
\hline & A3 & como que é? herbácea? & \\
\hline & Pr & uhum & \\
\hline & $\mathbf{A 3}$ & $\begin{array}{l}\text { ó pr... porque a herbácea foi mais apropriada para viver em lugar próximo ao mar } \\
\text { por ter as raízes bastante profunda e sistema das raízes é em rizomas que fixa as } \\
\text { plantas na areia e mantém as herbácea mais estáveis }\end{array}$ & Lê a resposta \\
\hline & Pr & bom... muito bom & \\
\hline & Pr & quem não terminou ainda?...quem não terminou? vou recolher então... & \\
\hline
\end{tabular}

\begin{tabular}{|c|c|c|}
\hline \multicolumn{2}{|c|}{ EPISÓDIO 4 - DISCUSSÃO } & \multirow{2}{*}{$\begin{array}{l}\text { vamo discutir um pouquinho o problema que a gente tinha pra } \\
\text { resolver?ó...seguinte...que que nós tínhamos?nós tínhamos um...uma modificação } \\
\text { na vegetação não tínhamos?tivemos...não tivemos uma modificação na } \\
\text { vegetação?antes quando a massa de areia era muito extensa a vegetação herbácea } \\
\text { ocupava uma determinada linha não é?quando o mar se aproximou essa vegetação } \\
\text { herbácea conseguiu o que...invadir uma área que era só da arbustiva...a primeira } \\
\text { coisa que a gente fez quando eu comecei a dar a atividade pra vocês foi responder } \\
\text { aquela pergunta se a vegetação ia ou não se alterar...ceis mudaram de } \\
\text { opinião?alguém colocou que não ia e depois viu que ia ou colocou que ia e aí } \\
\text { depois achou que não mudou?alguém teve essa mudança ou não? }\end{array}$} \\
\hline 01 & Pr & \\
\hline $\mathbf{0 2}$ & A? & $\operatorname{sim}$ \\
\hline 03 & Pr & cê mudou?não mudou?cê falou o que que ia?e foi...não foi?a gente viu que foi né? \\
\hline 04 & A6 & $\begin{array}{l}\text { assim...a vegetação herbácea necessita mesmo dessa presença mais forte do mar } \\
\text { mas aí também começou a atingir a arbustiva e ela necessitava da serrapilheira pra } \\
\text { pegar os nutrientes e acabou morrendo por falta dela e a herbácea tomou conta do } \\
\text { local }\end{array}$ \\
\hline 05 & Pr & $\begin{array}{l}\text { muito bom...o que a gente viu a gente viu que houve uma alteração da mudança da } \\
\text { vegetação...foi ou não foi?e essa mudança na vegetação aconteceu por que? A6 }\end{array}$ \\
\hline
\end{tabular}




\begin{tabular}{|c|c|c|}
\hline & & $\begin{array}{l}\text { tava falando pra gente...com a aproxmação do mar a gente mudou as condições } \\
\text { físicas do ambiente não mudou?a arbustiva tava preparada pra ficar mais próxima } \\
\text { do mar? }\end{array}$ \\
\hline 06 & As & não \\
\hline 07 & Pr & em compensação a herbácea ela é adaptada pra ficar próxima do mar? \\
\hline $\mathbf{0 8}$ & As & é \\
\hline 09 & Pr & ela tem características que permite que ela viva alí \\
\hline 10 & A? & pelas raízes \\
\hline 11 & Pr & $\begin{array}{l}\text { isso...pelas raízes que fixam, pela quantidade de água que ela consegue reter...é ou } \\
\text { não é?concordam? }\end{array}$ \\
\hline 12 & $\mathbf{A 2 2}$ & é...cada vegetação tem uma característica adequada pra sobreviver num lugar \\
\hline 13 & Pr & $\begin{array}{l}\text { exatamente...e quando a gente mudou as características do ambiente com a } \\
\text { aproximação do mar a herbácea que é mais adaptada conseguiu o que?sobreviver e } \\
\text { expandir...a arbustiva conseguiu?não...muita vegetação arbustiva conseguiu o } \\
\text { que...é....aconteceu o que com elas?elas morreram não morreram?e formou o } \\
\text { que?uns espaços em branco que a gente chama de clareira...não é...uns espaços } \\
\text { vazios...é ou não é?que que acon...a herbácea como consegue sobreviver que que } \\
\text { ela fez com esse espaço vazio...ela o...cupou....deu pra entender?foi o que você } \\
\text { colocou?muito bom }\end{array}$ \\
\hline 14 & A5 & $\begin{array}{l}\text { eu coloquei que a arbustiva ela ia acabar morrendo porque ela não tá adaptada e a } \\
\text { herbácea ia tomar o seu lugar }\end{array}$ \\
\hline 15 & Pr & perfeito é isso mesmo que aconteceu \\
\hline 16 & A3 & o Pr também pelas raízes da herbácea ser bem mais aprofundada \\
\hline 17 & Pr & $\begin{array}{l}\text { a parte das raízes da herbácea permite que ela fique em local mais arenoso não } \\
\text { é...porque essas raízes mais profundas ela consegue o que fixar...é ou não é? }\end{array}$ \\
\hline 18 & A16 & $\begin{array}{l}\text { ô } \operatorname{Pr} \text { ( ) elas consegue reter a água mas por que elas retém a água se elas } \\
\text { tem...é...todo ( ) o mar taca água pra ela? }\end{array}$ \\
\hline 19 & Pr & $\begin{array}{l}\text { o mar é de uma água salgada e a gente tende sempre a perder água pro lugar mais } \\
\text { concentrado de sal...veja bem um exemplo claro...quando a mãe da gente faz uma } \\
\text { salada de alface.... a alface tem água não tem?todo ser vivo é formado por água não } \\
\text { é?e a gente tempera a alface com sal não temperamos?de repente esse alface faz o } \\
\text { que?ele murcha...porque ele perde essa água pro lugar mais salgado...isso ele } \\
\text { desidrata...a vegetação herbácea ela consegue o que?reter a água e sobreviver num } \\
\text { lugar onde a constante salinidade é maior...tem mais sal perto do mar?o mar não } \\
\text { joga uma água mais salgada? }\end{array}$ \\
\hline 20 & A? & $\operatorname{sim}$ \\
\hline 21 & Pr & deu pra entender agora? \\
\hline 22 & A16 & deu \\
\hline 23 & Pr & que falar mais alguma coisa? \\
\hline 24 & A16 & $\begin{array}{l}\text { é assim...também...da...as arbustivas...ela...tem mais o desempenho de } \\
\text { consegui...é....daqueles negócio de oxigênio ( ) }\end{array}$ \\
\hline 25 & Pr & de fazer fotossíntese? \\
\hline 26 & A16 & é \\
\hline 27 & Pr & todas as...todos os vegetais fazem fotossíntese...né...lembra \\
\hline 28 & A16 & mesmo na areia? \\
\hline 29 & Pr & $\begin{array}{l}\text { mesmo as que estão próximas da areia...por que...todo vegetal só consegue energia } \\
\text { através da... }\end{array}$ \\
\hline 30 & As & fotossíntese \\
\hline 31 & Pr & $\begin{array}{l}\text { fotossíntese...eles pegam a luz solar lembra do processo da fotossíntese?alguém } \\
\text { tem dúvida em relação a fotossíntese? }\end{array}$ \\
\hline 32 & A6 & $\begin{array}{l}\text { tipo assim a presença do mar...é traz mais freqüência de vento temperatura e leva a } \\
\text { serrapilheira que é necessária }\end{array}$ \\
\hline 33 & Pr & isso pra... \\
\hline 34 & A6 & é ideal pra vida das...arbustivas \\
\hline 35 & Pr & $\begin{array}{l}\text { arbustivas...exato...a A6 tá fazendo uma observação em relação aos nutrientes a } \\
\text { gente viu lá naquele texto naquele material de apoio que a vegetação arbustiva } \\
\text { apresenta uma camada de nutrientes né...que a gente chama de serrapilheira...a A6 } \\
\text { falou que quando vem essa água do mar essa serrapi...a serrapilheira vai } \\
\text { embora...mas o o mari...o mar não adentra a camada de areia...ele não }\end{array}$ \\
\hline
\end{tabular}




\begin{tabular}{|c|c|c|c|}
\hline & & ultrapassa...não chega na vegetação...é....arbustiva é só a proximidade & \\
\hline 36 & A6 & então a proximidade dele traz também o vento & \\
\hline 37 & Pr & o vento...isso que leva a serrapilheira embora...é isso que você tá dizendo? & \\
\hline 38 & A6 & é & \\
\hline 39 & Pr & $\begin{array}{l}\text { que leva embora essa serrapilheira e a planta fica sem os nutrientes?isso...isso } \\
\text { mesmo...mais alguma observação? }\end{array}$ & \\
\hline 40 & A16 & $\begin{array}{l}\text { assim...você falou que...das arbustivas...não é a água do mar que chega perto } \\
\text { dela...a água do mar não chega perto das arbustivas...então...como que elas } \\
\text { são...é...(aguadas) }\end{array}$ & \\
\hline 41 & Pr & chuva né ( ) & \\
\hline 42 & A16 & ( ) & \\
\hline 43 & $\mathbf{A 1 1}$ & Pr...a gente reveu tudo isso...a gente viu na apostila e no livro que você explicou & \\
\hline 44 & Pr & $\begin{array}{l}\text { foi...a gente tava estudando no primeiro bimestre a parte de adaptação...lembra que } \\
\text { a gente viu a adaptação da borboleta da mariposa?vocês lembram disso?e aqui } \\
\text { também né...a gente viu que os mais adaptados eles tem condições em...eles são } \\
\text { selecionados pelo ambiente não são?positivamente...não foi isso que a gente } \\
\text { aprendeu?devido as suas características não é?uma mudança ambiental vai } \\
\text { selecionar quem?os mais adaptados aquelas condições e a gente viu isso...muito } \\
\text { bem lembrado }\end{array}$ & \\
\hline 45 & $\mathbf{A 2 2}$ & $\begin{array}{l}\text { quanto tempo demoraria se não tivesse a vegetação } \\
\text { arbustiva...não...herbácea...quanto tempo demoraria pra vegetação arbustiva se } \\
\text { adaptar a viver perto da água do mar?ela se adaptaria? }\end{array}$ & \\
\hline 46 & Pr & $\begin{array}{l}\text { as mais adaptadas... sempre tem alguém que tem...lembra que a gente falou que a } \\
\text { variabilidade genética...lembram disso?e as mutações elas permitem que os seres } \\
\text { sejam o que?diferentes uns dos outros sempre tem aqueles que vão ficar...que vão } \\
\text { conseguir sobreviver a... }\end{array}$ & \\
\hline 47 & A? & ( ) & \\
\hline 48 & $\operatorname{Pr}$ & $\begin{array}{l}\text { isso os mais fortes...sempre tem aqueles que vão conseguir sobreviver às mudanças } \\
\text { ambientais mas tem aqueles que não conseguiram os que não conseguiram } \\
\text { morreram...e os que....no lugar daqueles que morreram a herbácea mais adaptada } \\
\text { invadiu...certo?deu pra entender galera? }\end{array}$ & \\
\hline 49 & A? & deu & \\
\hline 50 & Pr & alguma dúvida?alguém quer tirar alguma dúvida? & \\
\hline 51 & $\mathbf{A 3}$ & $\begin{array}{l}\text { ô Pr...a herbácea ela...ela só...vive na no lugar onde tem mais a proximidade do } \\
\text { mar? }\end{array}$ & \\
\hline 52 & Pr & $\begin{array}{l}\text { isso...ela é mais adaptada em regiões próximas do mar...ela consegue viver alí por } \\
\text { causa daquelas características que nós vimos no material de apoio }\end{array}$ & \\
\hline 53 & $\mathbf{A 3}$ & $\begin{array}{l}\text { então se ela viver tipo...igual a ar...arbustiva ela não vai sobreviver?por que ela } \\
\text { precisa ter... }\end{array}$ & \\
\hline 54 & Pr & $\begin{array}{l}\text { não é que ela precisa ter...ela consegue sobreviver perto do mar por aquelas } \\
\text { condições porque ela tem características próprias praquilo....entendeu?pra viver } \\
\text { naquele lugar }\end{array}$ & \\
\hline 55 & A3 & porque cada...cada ser tem suas & \\
\hline 56 & & as adaptações...isso & \\
\hline 57 & A6 & $\begin{array}{l}\text { professora no texto falava também que a frequiência de animais era maior na } \\
\text { vegetação arbustiva porque eles teriam que se deslocar porque ela ia ficar ausente }\end{array}$ & \\
\hline 58 & Pr & $\begin{array}{l}\text { isso...tem a questão...mexe com todo o...ecossistema do local não mexe?bem } \\
\text { lembrado...alguma dúvida? }\end{array}$ & \\
\hline 59 & As & não & \\
\hline 60 & Pr & finalizamos o assunto? & \\
\hline 61 & As & $\operatorname{sim}$ & \\
\hline 62 & Pr & gente brigada...é isso mesmo...ceis tiveram alguma dúvida?acharam difícil? & \\
\hline 63 & A1 & $\operatorname{sim}$ & \\
\hline 64 & A2 & não & \\
\hline 65 & A1 & só um tiquinho & \\
\hline 66 & Pr & $\begin{array}{l}\text { alguém colocou uma resposta muito diferente?quem não conseguiu entender e } \\
\text { respondeu errado?ai acho que respondi errado...ninguém? nossa que beleza }\end{array}$ & \\
\hline 67 & $\mathbf{A 3}$ & ô Pr...e do outro? & \\
\hline 68 & Pr & que outro? & \\
\hline
\end{tabular}




\begin{tabular}{|c|c|c|c|}
\hline 69 & $\mathbf{A 3}$ & o outro exercício?o primeiro? & \\
\hline 70 & Pr & aquele era só pra ver se você & \\
\hline 71 & A2 & era a sua opinião & \\
\hline 72 & $\operatorname{Pr}$ & $\begin{array}{l}\text { não tem um certo ou errado...era a sua opinião...você....depois nós vimos com o } \\
\text { desenrolar que a vegetação ela é sim alterada não é?queria saber num primeiro } \\
\text { momento se você acha que ela ia ou não ser alterada e se você ia ou não mudar de } \\
\text { opinião...tá era mais um...pra você fazer uma observação...pra você vê o que que } \\
\text { você acha antes e depois com a leitura e o desenrolar do problema se você muda ou } \\
\text { não de opinião... }\end{array}$ & \\
\hline 73 & A? & ( ) & \\
\hline 74 & Pr & é...a gente viu que ela foi alterada...certo?certo?então vamo lá... & \\
\hline 75 & A16 & $\begin{array}{l}\text { ô Pr teve uma pessoa aqui na sala que aquela se sofre ou não sofre as reações } \\
\text { colocou as duas que que vai fazê? }\end{array}$ & \\
\hline 76 & Pr & $\begin{array}{l}\text { não...quando a gente colo.... gente viu que cada um tinha uma opinião se sofria ou } \\
\text { não alteração e com o desenrolar do problema com a análise do material de apoio } \\
\text { tudo a gente viu que....sofre...aí essa pessoa depois agora...quem colocou as duas } \\
\text { percebeu que sofreu alteração? }\end{array}$ & \\
\hline 77 & As & $(($ risadas $))$ & $\begin{array}{l}\text { Alunos apontam } \\
\text { para A12 }\end{array}$ \\
\hline 78 & Pr & cê entendeu A12 depois? & \\
\hline 79 & A12 & não fui eu não & \\
\hline 80 & Pr & $\begin{array}{l}\text { deixa...cada um responde o que acha né gente...cada um tem o direito de achar o } \\
\text { que bem entender...não é?só tem que entender que depois né....no desenvolver do } \\
\text { problema a gente viu que sofre alteração }\end{array}$ & \\
\hline 81 & A? & ( ) & \\
\hline 82 & Pr & o que? & \\
\hline 83 & $\mathbf{A 1 3}$ & $\begin{array}{l}\text { ( ) aquilo lá não tá muito adaptado praquele local então que acontece...vai morrer } \\
\text { tudo?a maioria...né? }\end{array}$ & \\
\hline 84 & Pr & vai acontecer a mesma coisa...só vai sobreviver as plantas mais adaptadas & \\
\hline 85 & A13 & ( ) vai morrer mais ( ) & \\
\hline 86 & Pr & $\begin{array}{l}\text { isso onde a água tá adentrando vai sobreviver as mais adaptadas certo? amanhã } \\
\text { volta o normal...aí vocês tragam a apostila que nós vamos continuar a matéria }\end{array}$ & \\
\hline
\end{tabular}




\begin{tabular}{|c|c|c|c|}
\hline TURNO & SUJEITO & FALA & ATITUDE \\
\hline 1 & ME & $\begin{array}{l}\text { bom Pr então... eu vô fazê a leitura tá do roteiro de } \\
\text { orientações da sequência didática... caso você tenha } \\
\text { alguma pergunta você pode me interromper em qualquer } \\
\text { momento...é... fazer as adequações que você quiser e a } \\
\text { gente discute segundo os objetivos da } \\
\text { sequência...tá?...então você vai aplicar a sequência } \\
\text { didática e a minha função aqui como mediador é passar as } \\
\text { informações em relação à sequência...e você pode dar } \\
\text { qualquer opinião...qualquer adequação que você quiser } \\
\text { contanto que...eu vô fazê a leitura dos objetivos e a gente } \\
\text { não fuja dos objetivos da sequência }\end{array}$ & DESCREVE \\
\hline 2 & $\mathbf{P R}$ & ok & ACEITA \\
\hline 3 & ME & $\begin{array}{l}\text { tá bom?então tá...o "desenvolvimento da sequência } \\
\text { didática...objetivo central é que, a partir de um problema, } \\
\text { os alunos possam elaborar textos escritos argumentativos } \\
\text { tendo como base a leitura de um texto descritivo em que é } \\
\text { tratada relações entre fatores abióticos e estruturas } \\
\text { adaptativas de plantas da Restinga...tá? }\end{array}$ & DESCREVE \\
\hline 4 & PR & ok & ACEITA \\
\hline 5 & ME & $\begin{array}{l}\text { "o conteúdo a ser ensinado...na restinga a proximidade } \\
\text { do mar atua como fator fortemente seletivo para a } \\
\text { instalação e crescimento da vegetação...as plantas são } \\
\text { sujeitas a...ventos fortes carregados de partículas de } \\
\text { sal...luminosidade excessiva... escassez de } \\
\text { nutrientes...grande instabilidade e deduzida } \\
\text { disponibilidade de água devido à alta permealidade dos } \\
\text { terrenos arenosos...conforme se distancia do } \\
\text { mar...observa-se que há modificações na vegetação as } \\
\text { quais refletem as condições do solo que tornam-se mais } \\
\text { estáveis...firmes...com menor permeabilidade e maior } \\
\text { disponibilidade de nutrientes....as fisionomias tornam-se } \\
\text { mais complexas a medida que estão mais distantes do } \\
\text { mar"...então esse é o conteúdo...tá? }\end{array}$ & DESCREVE \\
\hline 6 & PR & tá & ACEITA \\
\hline 7 & ME & $\begin{array}{l}\text { mas o objetivo é trazer um problema e aí promover } \\
\text { aí...é....a elaboração de textos argumentativos escritos a } \\
\text { partir desse conteúdo...tá?então...agora a gente vai } \\
\text { descrever a sequência didática passo a passo...e aí a } \\
\text { primeira coisa que eu vô pedir pra você é pegar a } \\
\text { atividade um }\end{array}$ & DESCREVE \\
\hline 8 & PR & tá aqui & ACEITA \\
\hline 9 & ME & $\begin{array}{l}\text { isso...é essa que tem um trecho do jornal da } \\
\text { ciência...tá...é...traz aí dados referentes à elevação do } \\
\text { nível do mar... }\end{array}$ & DESCREVE \\
\hline 10 & PR & tá & \\
\hline 11 & ME & $\begin{array}{l}\text { é suas conseqüências para cidades litorâneas...esse texto } \\
\text { aqui o objetivo dele é aproximar os estudantes das } \\
\text { questões colocadas pela mídia...né da própria...temática } \\
\text { do aquecimento global e as relações da elevação do nível } \\
\text { do mar e a destruição das cidades...então...a....seria } \\
\text { interessante se você pudesse ler em voz alta e explicar o } \\
\text { texto }\end{array}$ & DESCREVE \\
\hline 12 & PR & $\operatorname{sim}$ & ACEITA \\
\hline 13 & ME & junto com os alunos & DESCREVE \\
\hline 14 & $\mathbf{P R}$ & tá ok & ACEITA \\
\hline
\end{tabular}




\begin{tabular}{|c|c|c|c|}
\hline 15 & ME & $\begin{array}{l}\text { o texto é um trecho bem curtinho que é o seguinte ó... "o } \\
\text { avanço do mar...pesquisa da USP revela que o nível do } \\
\text { oceano no Brasil sobe quatro milímetros por ano...índice é } \\
\text { considerado alto e coloca em risco áreas litorâneas do } \\
\text { país...não há dúvida de que o nível do mar tem aumentado } \\
\text { gradativamente no litoral brasileiro...a conclusão consta } \\
\text { de estudo realizado pelo instituto oceanográfico da } \\
\text { universidade de são paulo io USP....alerta significa que o } \\
\text { país pode sofrer no futuro com uma das piores } \\
\text { conseqüêencias do aquecimento global a destruição de } \\
\text { regiões inteiras localizadas próximo à costa...as possíveis } \\
\text { conseqüências do fenômeno vão da perda da faixa de } \\
\text { areia à destruição de cidades...passando por ressacas mais } \\
\text { violentas e inúmeros outros transtornos...Milton } \\
\text { Kampel...especialista do instituto nacional de pesquisas } \\
\text { espaciais...inpe...diz que a elevação do oceano preocupa } \\
\text { porque as regiôes costeiras costumam ter alta densidade } \\
\text { populacional...milhões de pessoas vivem numa faixa entre } \\
\text { um metro e cinco metros da linha da costa" }\end{array}$ & DESCREVE \\
\hline 16 & PR & ok & \\
\hline 17 & ME & $\begin{array}{l}\text { tudo bem? então esse é o trecho do jornal a ser feita a } \\
\text { leitura em voz alta e após a leitura do } \\
\text { texto...é...é....mostrar...é...ele ressalta a ocupação das } \\
\text { cidades litorâneas nessa faixa e pode ser que surja aí } \\
\text { nesse caso...uma dúvida que é em relação a definição de } \\
\text { restinga }\end{array}$ & DESCREVE \\
\hline 18 & PR & tá & ACEITA \\
\hline 19 & ME & $\begin{array}{l}\text { tá? nesse primeiro momento...a idéia aqui pra proposta é } \\
\text { que só diga que é um local caracteriza...é...a vegetação } \\
\text { característica desse local...tá? não necessitando de } \\
\text { maiores detalhes }\end{array}$ & DESCREVE \\
\hline 20 & PR & certo & ACEITA \\
\hline 21 & ME & $\begin{array}{l}\text { "e cada vez mais casas e edifícios são construídos ao } \\
\text { longo das planícies litorâneas para abrigar essa } \\
\text { quantidade enorme de pessoas...e consequentemente, a } \\
\text { vegetação ali existente a restinga é devastada...hoje em } \\
\text { dia são poucas as restingas ainda preservadas em todo o } \\
\text { Brasil"..então a idéia agora é mostrar duas imagens cê tá } \\
\text { vendo a figura um...retinga do estaleiro em Ubatuba e a } \\
\text { figura dois que é a praia de santos...né?santos são } \\
\text { Paulo...então a idéia aqui agora é mostrar aos estudantes o } \\
\text { que que é uma restinga mesmo...né...e a planície que ela } \\
\text { ocupa...então é muito importante aqui se você puder } \\
\text { enfatizar a região que a gente tá chamando de } \\
\text { planície...mostrando pros alunos a distância entre a linha } \\
\text { do mar e do morro tá?e as diferenças...por exemplo a } \\
\text { vegetação nativa ocupando aqui essa região e na figura }\end{array}$ & DESCREVE \\
\hline 22 & PR & ocupada & \\
\hline 23 & ME & $\begin{array}{l}\text { exatamente a figura ocupada pela zona urbana...tudo bem } \\
\text { até aí? }\end{array}$ & \\
\hline 24 & PR & tudo & \\
\hline 25 & ME & tranquilo?tem alguma adequação que cê queria... & $\begin{array}{l}\text { ESTIMULA } \\
\text { MODIFICAÇÕES }\end{array}$ \\
\hline 26 & PR & não tranquilo... & \\
\hline 27 & ME & então & \\
\hline 28 & PR & podemos continuar & \\
\hline 29 & ME & podemos continuar tá? & \\
\hline 30 & PR & tá & \\
\hline 31 & ME & $\begin{array}{l}\text { então o que a gente fez na primeira parte foi fazê essa } \\
\text { relação entre a elevação do nível do mar e cidades }\end{array}$ & DESCREVE \\
\hline 32 & PR & tá & \\
\hline 33 & ME & e destacamos a divulgação disso lá no jornal na mídia ao & DESCREVE \\
\hline
\end{tabular}




\begin{tabular}{|c|c|c|c|}
\hline & & $\begin{array}{l}\text { contrário de elevação do nível do mar e vegetação que } \\
\text { dificilmente a gente se discute isso...então...é...talvez aí } \\
\text { nesse momento fazer um link dessa idéia...é...entre essa } \\
\text { questão da elevação do nível do mar e a destruição de } \\
\text { cidade e o que possivelmente pode ocorrer numa região } \\
\text { onde não tem cidade mas sim uma restinga preservada }\end{array}$ & \\
\hline 34 & PR & tá & ACEITA \\
\hline 35 & ME & $\begin{array}{l}\text { então “ vimos no início da atividade que a elevação do } \\
\text { nível do mar está na maioria das vezes associado à } \\
\text { destruição de cidades litorâneas figura três e } \\
\text { constantemente é possível encontrar essas informações } \\
\text { nos jornais na televisão e na internet”...então a figura três } \\
\text { aí mostrando }\end{array}$ & DESCREVE \\
\hline 36 & $\mathbf{P R}$ & uma área devastada & \\
\hline 37 & ME & $\begin{array}{l}\text { uma área devastada urbana...tá...então a calçada sendo } \\
\text { atingida aí pela elevação do nível do mar... "Porém, } \\
\text { pouco se fala das consequiências da elevação do nível do } \\
\text { mar nas áreas em que a vegetação ainda é preservada" } \\
\text { então daí lança-se a questão "pense...quais seriam as } \\
\text { conseqüências? Será que a vegetação existente nessas } \\
\text { áreas pode ser afetada com a aproximação do mar?" } \\
\text { entendeu a relação? }\end{array}$ & DESCREVE \\
\hline 38 & PR & entendi & ACEITA \\
\hline 39 & ME & $\begin{array}{l}\text { então já que o pólo discutido é a questão das cidades...a } \\
\text { questão levantada é...e quais as consequiências?né...se }\end{array}$ & DESCREVE \\
\hline 40 & PR & levá essa discussão pra uma área natural...preservada & \\
\hline 41 & ME & $\begin{array}{l}\text { isso... a elevação do nível do mar pra vegetação em áreas } \\
\text { que não estão ocupadas pela zona urbana...tá...só que } \\
\text { antes deles pensarem nessa questão...é importante que a } \\
\text { gente leia o quadro aqui abaixo na sequência que tá } \\
\text { escrito atenção...tá...por que?porque na verdade pode ser } \\
\text { que ocorra de uma...de uma idéia assim de um tsunami ou } \\
\text { uma...carga muito grande de água por algum fenômeno } \\
\text { natural que desapareça de uma vez só com toda essa } \\
\text { vegetação }\end{array}$ & DESCREVE \\
\hline 42 & $\mathbf{P R}$ & tá & ACEITA \\
\hline 43 & ME & na verdade a idéia é trabalhar o aumento gradativo & DESCREVE \\
\hline 44 & PR & $\operatorname{sim}$ & ACEITA \\
\hline 45 & ME & tudo bem? & \\
\hline 46 & PR & tudo & \\
\hline 47 & ME & $\begin{array}{l}\text { então até que o quadro atenção tá escrito o seguinte... "É } \\
\text { claro que se o volume das águas do mar subisse de uma } \\
\text { só vez e cobrisse toda a planície litorânea...toda Restinga } \\
\text { iria por água a baixo e deixaria de existir mas estamos } \\
\text { falando de um aumento no nível do mar que ocorre aos } \\
\text { poucos, diminuindo a faixa de areia entre a vegetação e o } \\
\text { mar ou seja o mar vai se aproximando da vegetação mas } \\
\text { não chega a cobri-la de uma vez"...então esse é o contexto } \\
\text { do problema colocado tá? }\end{array}$ & DESCREVE \\
\hline 48 & PR & tá & ACEITA \\
\hline 49 & ME & $\begin{array}{l}\text { ahh...quando ficar bem claro esse problema e o contexto } \\
\text { do qual você tá falando...é interessante que seja lançada } \\
\text { duas possíveis hipóteses para que eles completem e eles } \\
\text { escolham }\end{array}$ & DESCREVE \\
\hline $\mathbf{5 0}$ & PR & tá & ACEITA \\
\hline 51 & ME & $\begin{array}{l}\text { então é a seguinte questão... "dessa forma você acredita } \\
\text { que com a aproximação do mar em áreas } \\
\text { preservadas...um....a vegetação não é afetada pois... }\end{array}$ & DESCREVE \\
\hline
\end{tabular}




\begin{tabular}{|c|c|c|c|}
\hline 52 & PR & completa & \\
\hline 53 & ME & $\begin{array}{l}\text { aí eles precisam completar... se a aproximação do mar não } \\
\text { afeta a vegetação...então... esperamos que... e aí eles } \\
\text { completam...a afirmativa dois...a hipótese dois é a } \\
\text { vegetação pode ser afetada...pois...e aí eles explicam...ou } \\
\text { se a aproximação do mar afeta a vegetação então } \\
\text { esperamos que...aí eles completam }\end{array}$ & DESCREVE \\
\hline 54 & PR & ok & ACEITA \\
\hline 55 & ME & $\begin{array}{l}\text { até aí tudo bem?se tiver alguma sugestão...alguma coisa } \\
\text { cê pode...interromper }\end{array}$ & $\begin{array}{l}\text { ESTIMULA } \\
\text { MODIFICAÇÕES }\end{array}$ \\
\hline 56 & $\mathbf{P R}$ & ok & \\
\hline 57 & ME & $\begin{array}{l}\text { então... "explique aos alunos que as hipóteses levantadas } \\
\text { da atividade anterior serão discutidas no fim de toda a } \\
\text { sequência"...então eles vão fazer a hipótese...construir a } \\
\text { hipótese e isso vai ser discutido no final de toda a } \\
\text { sequência... "entregue a atividade dois para os alunos e } \\
\text { diga que veremos o que poderia acontecer com a elevação } \\
\text { do nível do mar em regiões de restinga } \\
\text { preservada"...então a atividade dois agora vai explorar } \\
\text { essa situação... "explique o detalhe das ampliações do } \\
\text { mapa e que as fotos da figura } 2 \text { são vistas de cima de um } \\
\text { ponto da Ilha do Cardoso...mostre também a sua } \\
\text { localização...mostre a diferença entre a largura da faixa de } \\
\text { praia da figura um e dois evidenciando a elevação do } \\
\text { nível do mar" então aqui só deixar claro pra eles e você } \\
\text { enfatizar que nessas figuras você tem uma diferença de } \\
\text { escala cartográfica dos mapas...então quer dizer tem uma } \\
\text { primeira imagem da américa latina enfatizando o } \\
\text { brasil...enfatiza-se o estado de são paulo...você mostra } \\
\text { essa ênfase...no estado de sâo paulo está marcado a região } \\
\text { onde está a ilha do cardoso isso é ampliado...a ampliação } \\
\text { da ilha mostra essa região da ilha e aí sim a região da ilha } \\
\text { que são essas duas regiões...desculpa...a região da ilha } \\
\text { onde você tem a imagem antes dum... }\end{array}$ & DESCREVE \\
\hline 58 & PR & elevação & \\
\hline 59 & ME & isso... & \\
\hline 60 & PR & antes e depois de quinze anos & \\
\hline 61 & ME & $\begin{array}{l}\text { perfeito...então antes da elevação do nível do mar e } \\
\text { depois da elevação do nível do mar...né...e aí é importante } \\
\text { ressaltar pra eles nesse momento focar na figura na } \\
\text { imagem a diferença na faixa de areia cê consegue } \\
\text { perceber aí? }\end{array}$ & DESCREVE \\
\hline 62 & PR & antes era maior depois ficou menor...mais estreito & \\
\hline 63 & ME & mais estreito então é visível...né? & \\
\hline 64 & PR & visível & ACEITA \\
\hline 65 & ME & $\begin{array}{l}\text { que ficou mais estreito quinze anos depois da } \\
\text { aproximação do nível do mar...então a figura A apresenta } \\
\text { a faixa da praia mais estreita que a figura B } \\
\text { caracterizando elevação do nível do mar na região no } \\
\text { decorrer desses } 15 \text { anos...tá...tudo bem? }\end{array}$ & DESCREVE \\
\hline 66 & PR & $\begin{array}{l}\text { figura } \mathrm{A} \text { apresenta a faixa da praia mais estreita que a } \\
\text { figura B?tá trocado não é?a figura B apresenta faixa }\end{array}$ & QUESTIONA \\
\hline 67 & ME & isso & ACEITA \\
\hline 68 & PR & tem que corrigir né? & QUESTIONA \\
\hline 69 & ME & tem...tá certo...é isso mesmo...Pr & ACEITA \\
\hline 70 & PR & e a B que é mais estreita & \\
\hline 71 & ME & a figura $\mathrm{B}$ apresenta a faixa de areia mais estreita & QUESTIONA \\
\hline 72 & PR & isso & ACEITA \\
\hline 73 & ME & $\begin{array}{l}\text { do que a A caracterizando a elevação do nível do mar na } \\
\text { região no decorrer desses quinze anos }\end{array}$ & QUESTIONA \\
\hline 74 & $\mathbf{P R}$ & ok & ACEITA \\
\hline 75 & ME & $\begin{array}{lllll}\text { perfeito...é } & \text { isso } & \text { mesmo...bem } & \text { observado... } & \text { “em } \\
\end{array}$ & \\
\hline
\end{tabular}




\begin{tabular}{|c|c|c|c|}
\hline & & $\begin{array}{l}\text { seguida...as figuras têm como foco as mudanças na } \\
\text { vegetação agora...mostre onde situam as vegetações: } \\
\text { herbácea e a arbustiva e suas características baseadas nas } \\
\text { fotos do detalhe além disso...mostre que a vegetação } \\
\text { herbácea adentra a região onde havia vegetação } \\
\text { arbustiva...vê se você consegue identificar que na } \\
\text { primeira imagem...os pontos vermelhos }\end{array}$ & DESCREVE \\
\hline 76 & $\mathbf{P R}$ & representam a vegetação arbustiva & \\
\hline 77 & ME & representam a vegetação herbácea & QUESTIONA \\
\hline 78 & PR & herbácea...verdade & ACEITA \\
\hline 79 & ME & $\begin{array}{l}\text { exatamente e a regiãoverde escura...é onde você tem a } \\
\text { vegetação arbustiva }\end{array}$ & DESCREVE \\
\hline 80 & $\mathbf{P R}$ & $\operatorname{sim}$ & \\
\hline 81 & ME & $\begin{array}{l}\text { então na imagem aqui ao lado você tem dois quadros } \\
\text { mostrando exatamente a fisionomia de uma região } \\
\text { arbustiva em baixo e da herbácea em cima... }\end{array}$ & DESCREVE \\
\hline 82 & PR & ok & \\
\hline 83 & ME & $\begin{array}{l}\text { e importante porque como o mapa é uma representação } \\
\text { você mostrar como é exatamente....agora veja em baixo o } \\
\text { que acontece.... vegetação arbustiva ela começa a ter } \\
\text { algumas lacunas nessas regiões como você vê na figura }\end{array}$ & DESCREVE \\
\hline 84 & PR & deu pra perceber & \\
\hline 85 & ME & $\begin{array}{l}\text { então... "perceba que antes a vegetação herbácea } \\
\text { predominava na faixa da praia beirando a vegetação } \\
\text { arbustiva...A...com a aproximação do mar em B a } \\
\text { vegetação herbácea começou a adentrar e aparecer com } \\
\text { mais frequência nas regiões onde antes a vegetação } \\
\text { arbustiva era mais concentrada...quer dizer...a figura B é a } \\
\text { mesma figura que mostra quinze anos depois quando o } \\
\text { mar avançou }\end{array}$ & DESCREVE \\
\hline 86 & $\mathbf{P R}$ & certo & \\
\hline 87 & ME & $\begin{array}{l}\text { tudo bem? "não havendo dúvidas quanto às imagens... aí } \\
\text { você vai pedir pros alunos desenvolve um texto a partir } \\
\text { disso... um texto escrito... tá? respondendo às questões } \\
\text { explique que eles deverão utilizar o texto de apoio } \\
\text { grifando as principais informações que julgam ajudá-los a } \\
\text { responder a essas questões não esqueça é importante que } \\
\text { grifem assim em termos de pesquisa buscaremos entender } \\
\text { de que maneira o aluno compreende o texto descritivo e } \\
\text { como ele o utiliza no desenvolvimento das suas } \\
\text { explicações }\end{array}$ & DESCREVE \\
\hline 88 & PR & ok & ACEITA \\
\hline 89 & ME & $\begin{array}{l}\text { então esse aqui é um texto de apoio...tá ...o material de } \\
\text { apoio...quando ele receber o texto de apoio ele tem uma } \\
\text { questão pra responder que é aquela questão problema...ele } \\
\text { vai ler o texto de apoio e você peça assim...olha...os } \\
\text { textos...os trechos que forem importantes pra... }\end{array}$ & DESCREVE \\
\hline 90 & PR & você grifa & \\
\hline 91 & ME & você grifa pra mim & DESCREVE \\
\hline 92 & PR & pra resolução do problema & \\
\hline 93 & ME & $\begin{array}{l}\text { não é o que for importante assim...pra ele fazer o resumo } \\
\text { como tá acostumado a fazer...mas o que for importante } \\
\text { pra resolução do problema }\end{array}$ & DESCREVE \\
\hline 94 & PR & ok & ACEITA \\
\hline 95 & ME & cê acha que tá tudo bem essa parte?eles fariam? & \\
\hline 96 & $\mathbf{P R}$ & tranqüilo & ACEITA \\
\hline 97 & ME & $\begin{array}{l}\text { depois também dá uma olhada no texto de apoio pra vê se } \\
\text { você acha adequado pra turma...tá...dá uma olhada que } \\
\text { você pode sugerir adequações }\end{array}$ & $\begin{array}{l}\text { ESTIMULA } \\
\text { MODIFICAÇÕES }\end{array}$ \\
\hline
\end{tabular}




\begin{tabular}{|c|c|c|c|}
\hline 98 & PR & tá & \\
\hline 99 & ME & $\begin{array}{l}\text { "agora, com base no material de apoio responda...por que, } \\
\text { com a aproximação do mar a vegetação herbácea } \\
\text { começou a aparecer com mais frequência onde antes } \\
\text { predominava a vegetação arbustiva? Como se deu esse } \\
\text { processo?" sabe a imagem mostrando... o avanço? }\end{array}$ & DESCREVE \\
\hline 100 & PR & $\begin{array}{l}\text { sim...por que um lugar que a gente não tinha uma } \\
\text { vegetação agora a gente tem...né...é isso }\end{array}$ & \\
\hline 101 & ME & $\begin{array}{l}\text { e...exatamente na imagem que ocorreu o aumento do } \\
\text { nível do mar...você houve...houve uma mudança na } \\
\text { ocupação da vegetação...como ele explica isso?tá? }\end{array}$ & DESCREVE \\
\hline 102 & $\mathbf{P R}$ & 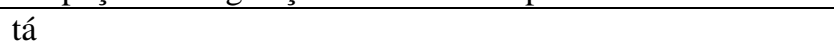 & ACEITA \\
\hline 103 & ME & $\begin{array}{l}\text { o texto de apoio que você tem é um texto } \\
\text { descritivo...né...então ele vai usar as informações de } \\
\text { acordo com o que ele achar importante }\end{array}$ & DESCREVE \\
\hline 104 & PR & $\begin{array}{l}\text { e aqui sim...nesse texto vai tá a definição de restinga...e } \\
\text { tudo mais que antes eu não tinha definido alí no começo... }\end{array}$ & \\
\hline 105 & ME & $\begin{array}{l}\text { exatamente...não define no começo porque agora no texto } \\
\text { ele vai te informações...ele não acha no texto...e uma } \\
\text { coisa que talvez você possa conversar com eles...um lugar } \\
\text { onde ele acha uma resposta... }\end{array}$ & ORIENTA \\
\hline 106 & PR & tá & ACEITA \\
\hline 107 & ME & $\begin{array}{l}\text { na verdade ele tem que construir um texto } \\
\text { argumentativo...ele vai usar as informações pra construir } \\
\text { o texto dele }\end{array}$ & EXPLICA \\
\hline 108 & PR & sim...ele não vai achar no texto isso & \\
\hline 109 & ME & uma resposta pronta & \\
\hline 110 & PR & tá & \\
\hline 111 & ME & $\begin{array}{l}\text { finalizando verifique quantos alunos mudaram de opinião } \\
\text { comparando-se as respostas da atividade um e } \\
\text { dois...lembra as duas hipóteses? }\end{array}$ & DESCREVE \\
\hline 112 & PR & as perguntas...se alteravam ou não a vegetação & \\
\hline 113 & ME & $\begin{array}{l}\text { sim...exatamente...ele deu aquela...ele completou fez } \\
\text { aquelas duas hipóteses... "discuta com os alunos } \\
\text { conduzindo a uma explicação mais viável para o } \\
\text { problema é importante que fique claro que essa não é uma } \\
\text { situação verídica e que nem mesmo pode ser considerada } \\
\text { uma resposta definitiva pois existem outros diversos } \\
\text { fatores que podem influenciar na dinâmica de um } \\
\text { ecossistema e que além disso o problema não partiu de } \\
\text { nenhuma pesquisa científica"...né? assim só elucidar pra } \\
\text { eles que é uma situação...é...que foi construída não é } \\
\text { real...não é o único fator que determina as mudanças de } \\
\text { um ecossistema }\end{array}$ & DESCREVE \\
\hline 114 & $\mathbf{P R}$ & $\operatorname{sim}$ & ACEITA \\
\hline 115 & ME & deixá claro que é uma atividade didática & DESCREVE \\
\hline 116 & PR & que tem outras variáveis & \\
\hline 117 & ME & isso & \\
\hline 118 & PR & não só uma...é que a gente só trabalhando uma & \\
\hline 119 & ME & $\begin{array}{l}\text { tudo bem até aí também?...então é nesse momento que a } \\
\text { gente retoma as duas hipóteses que eles colocaram...que } \\
\text { que mudou...quem mudou...por que mudou...tá?só pra } \\
\text { você ter clareza...a explicação do problema...que que seria } \\
\text { a expectativa sobre a explicação do problema }\end{array}$ & DESCREVE \\
\hline 120 & PR & $\operatorname{sim}$ & \\
\hline 121 & ME & $\begin{array}{l}\text { "com a elevação do nível do mar provavelmente algumas } \\
\text { características físicas do ambiente foram se } \\
\text { modificando...fatores como a alta salinidade a } \\
\text { disponibilidade de água a ação do vento movimentação da } \\
\text { areia e atrito começaram a influenciar diretamente na } \\
\text { vegetação arbustiva devido à ausência de estruturas }\end{array}$ & DESCREVE \\
\hline
\end{tabular}




\begin{tabular}{|c|c|c|c|}
\hline & & $\begin{array}{l}\text { adaptativas como ao contrário possuem as herbáceas } \\
\text { dessa forma...a sobrevivência das plantas arbustivas é } \\
\text { comprometida ao morrerem são abertas clareiras que } \\
\text { modificam as condições do solo umidade... aderência... } \\
\text { incidência direta do sol e assim torna difícil a instalação } \\
\text { de outras espécies arbustivas no lugar...assim a vegetação } \\
\text { herbácea que possui determinadas estruturas adaptativas } \\
\text { para essas condições se fixam nessas regiões onde antes } \\
\text { haviam arbustos" }\end{array}$ & \\
\hline 122 & PR & $\operatorname{sim}$ & \\
\hline 123 & ME & certo? & \\
\hline 124 & PR & certo & \\
\hline 125 & ME & $\begin{array}{l}\text { tranquilo?expectativa de resposta do aluno agora...aí você } \\
\text { vê se você acha que tá muito distante...se você esperaria } \\
\text { essas mesmas respostas ou não... "porque"...então ó... "a } \\
\text { vegetação herbácea adentrou regiões onde antes } \\
\text { predominava vegetação arbustiva porque a elevação do } \\
\text { nível do mar modificou as condições físicas do ambiente" } \\
\text { ou "a vegetação herbácea adentrou regiões onde antes } \\
\text { predominava vegetação arbustiva porque a vegetação } \\
\text { arbustiva foi afetada devido às condições que a ação do } \\
\text { mar passou a exercer devido à sua aproximação" ou "a } \\
\text { vegetação herbácea adentrou regiões onde antes } \\
\text { predominava vegetação arbustiva porque a vegetação } \\
\text { arbustiva não possui as mesmas características das plantas } \\
\text { herbáceas que as permitem sobreviver mais próximas ao } \\
\text { mar"... "como?" a pergunta como... "com a elevação do } \\
\text { nível do mar a região onde haviam plantas arbustivas } \\
\text { ficaram mais próximas da ação do mar...como elas não } \\
\text { possuem as mesmas características que possibilitam a } \\
\text { vegetação herbácea sobreviver nessas condições as } \\
\text { plantas morrem e então são ocupadas pelas herbáceas que } \\
\text { possuem condições para se fixar e se reproduzir } \\
\text { rapidamente" }\end{array}$ & DESCREVE \\
\hline 126 & PR & ok & \\
\hline 127 & ME & $\begin{array}{l}\text { tá?então...é...isso aqui são expectativas...né dando todos } \\
\text { os dados o texto de apoio...ãh...as atividades que foram } \\
\text { trabalhadas que ele chegue a essas conclusões...a essas } \\
\text { argumentações }\end{array}$ & DESCREVE \\
\hline 128 & PR & tá & \\
\hline 129 & ME & $\begin{array}{l}\text { mas isso são expectativas...né...isso não quer dizer que } \\
\text { eles tem que falar isso pra te dado certo pra você....você } \\
\text { vai conduzir a sequência...só foi colocado aqui pra você te } \\
\text { uma idéia das expectativas }\end{array}$ & DESCREVE \\
\hline 130 & PR & $\operatorname{sim}$ & \\
\hline 131 & ME & $\begin{array}{l}\text { não que você tenha que induzir ou forçar pra que ele diga } \\
\text { isso...você tem que colocar a situação e mediar a situação }\end{array}$ & DESCREVE \\
\hline 132 & $\mathbf{P R}$ & ele que tem que tirar essas conclusões & \\
\hline 133 & ME & $\begin{array}{l}\text { ele que chegue...ô PR mas e se ele chegar em outras } \\
\text { conclusões?são conclusões }\end{array}$ & QUESTIONA \\
\hline 134 & PR & $\operatorname{sim}$ & ACEITA \\
\hline 135 & ME & $\begin{array}{l}\text { ele pode chegar com quais conclusões que ele achar que } \\
\text { deve com base nos dados...caso ele esteje chegando a } \\
\text { conclusões sem fundamentação nos dados oferecidos aqui } \\
\text { o que que você pode fazer é reforçar os dados...olha...mas } \\
\text { qual é a relação da planta herbácea com o ambiente que } \\
\text { ela vive?porque de repente ele não tá considerando esse } \\
\text { dado...mas isso numa forma de mediar...é ele que tem que } \\
\text { chegar nas conclusões dele }\end{array}$ & ORIENTA \\
\hline 136 & $\mathbf{P R}$ & tá & ACEITA \\
\hline
\end{tabular}




\begin{tabular}{|c|c|c|c|}
\hline 137 & ME & $\begin{array}{l}\text { "os passos desta sequencia didática foram elaborados a } \\
\text { partir do seguinte formato...um....elaboração de um } \\
\text { problema a ser resolvido pelo aluno...então o resumo da } \\
\text { sequência agora...então o primeiro passo elaborou o seu } \\
\text { problema pra ser resolvido...consideramos importante } \\
\text { para o desenvolvimento desse problema uma situação que } \\
\text { envolvesse um assunto debatido na sociedade atual...a } \\
\text { elevação do nível do mar e suas consequências...dessa } \\
\text { forma aproximamos o aluno de questões que estão na } \\
\text { mídia e além disso envolvemos discussões no âmbito da } \\
\text { ciência que não são totalmente distantes da realidade } \\
\text { desses alunos"...o primeiro...premissa é essa... }\end{array}$ & DESCREVE \\
\hline 138 & $\mathbf{P R}$ & tá & \\
\hline 139 & ME & $\begin{array}{l}\text { "segundo passo...conhecimento prévio...levantamento de } \\
\text { hipóteses...após a introdução do problema é elaborado um } \\
\text { exercício em que o aluno defende um ponto de vista } \\
\text { baseado em seus conhecimentos prévios....ao final da } \\
\text { sequencia didática, o professor retoma esse exercício e } \\
\text { verifica se houve mudanças dessas concepções iniciais } \\
\text { dos alunos"...que é aquelas duas hipóteses... }\end{array}$ & DESCREVE \\
\hline 140 & $\mathbf{P R}$ & $\operatorname{sim}$ & \\
\hline 141 & ME & $\begin{array}{l}\text { "a observação nesta etapa o aluno terá em mãos uma } \\
\text { sequencia de figuras dados que corroboram uma das } \\
\text { hipóteses propostas anteriormente"...a argumentação é o } \\
\text { quarto ponto... "o aluno não será desafiado a dar } \\
\text { explicações a respeito da situação fornecida"...desculpa... } \\
\text { "o aluno então será desafiado a dar explicações a respeito } \\
\text { da situação fornecida nessa fase o aluno contará com um } \\
\text { texto de apoio que fornecerá bases teóricas para a } \\
\text { resolução da questão"...e o quinto passo que é a } \\
\text { discussão...o que é essa discussão? "finalizando a } \\
\text { sequencia didática o professor retomará as primeiras } \\
\text { considerações feitas pelos alunos verificando avaliando se } \\
\text { houve mudanças de concepções ou então o quanto as } \\
\text { explicações tornaram-se mas completas e com conteúdo } \\
\text { científico além disso o professor deverá verificar se } \\
\text { existem dúvidas e direcionar as discussões delineando o } \\
\text { conteúdo proposto". }\end{array}$ & DESCREVE \\
\hline 142 & PR & tá & \\
\hline 143 & ME & então aqui tem uma síntese da sequência & DESCREVE \\
\hline 144 & PR & tá & \\
\hline 145 & ME & $\begin{array}{l}\text { tá? e é isso PR eu queria saber se dentre esses passos que } \\
\text { eu te expliquei...objetivos...se você tem dúvida }\end{array}$ & \\
\hline 146 & PR & não eu não tenho... & \\
\hline 147 & ME & que que cê acha & QUESTIONA \\
\hline 148 & $\mathbf{P R}$ & $\begin{array}{l}\text { gostei porque vô tê duas aulas e acho que vô precisar de } \\
\text { duas aulas mesmo....acho que...tem muito conteúdo muita } \\
\text { informação pra ser dada em cinqüenta minutos }\end{array}$ & PLANEJA \\
\hline 149 & ME & certo & \\
\hline 150 & ME & essa aqui não é uma sequência de cinqüenta minutos & QUESTIONA \\
\hline 151 & PR & não & \\
\hline 152 & ME & não & \\
\hline 153 & PR & $\begin{array}{l}\text { pra ler bastante texto...leitura...leitura do material de } \\
\text { apoio...a análise da atividade dois...acho que realmente eu } \\
\text { vô precisar de duas aulas }\end{array}$ & PLANEJA \\
\hline 154 & ME & cê precisa de duas? & \\
\hline 155 & PR & $\begin{array}{l}\text { e...eu tenho duas...então vai ser tranquilo...eu tenho a } \\
\text { terceira e a quarta }\end{array}$ & PLANEJA \\
\hline 156 & ME & mas em duas você acha que dá? & QUESTIONA \\
\hline 157 & $\mathbf{P R}$ & duas acho que dá & \\
\hline
\end{tabular}




\begin{tabular}{|c|c|c|c|}
\hline 158 & ME & certo & \\
\hline 159 & PR & $\begin{array}{l}\text { porque tem que lê tudo e com certeza vão ter } \\
\text { dúvidas...interrupções da aula...né....então acho que } \\
\text { precisa de duas aulas mesmo }\end{array}$ & PLANEJA \\
\hline 160 & ME & $\begin{array}{l}\text { tem alguma coisa que você modificaria da sequência...que } \\
\text { você daria idéias para...pensando nos teus alunos? }\end{array}$ & $\begin{array}{l}\text { ESTIMULA } \\
\text { MODIFICAÇÕES }\end{array}$ \\
\hline 161 & $\mathbf{P R}$ & $\begin{array}{l}\text { não eu acho que...meu trabalho vai ser...eu vô tê que tê } \\
\text { um trabalho de mediadora muito grande...ler com } \\
\text { eles...explicando com calma...porque são assuntos que } \\
\text { eles não...adaptação eles já conhecem agora essa parte de } \\
\text { restinga eles nunca ouviram falar ainda...não tem } \\
\text { conhecimento muito aprofundado...então eu vô } \\
\text { aprofundar nessa parte }\end{array}$ & PLANEJA \\
\hline 162 & ME & entendi & \\
\hline 163 & PR & né porque adaptação eles já aprenderam... & PLANEJA \\
\hline 164 & ME & certo & \\
\hline 165 & PR & então eles tem o conteúdo de adaptação...eles já sabem & \\
\hline 166 & ME & eles já sabem & \\
\hline 167 & PR & $\begin{array}{l}\text { já sabem...alunos de } \text { sétimo ano já } \\
\text { conhecem...provavelmente eles vão fazer o link...espero } \\
\text { que sim também...porque eu já dei o assunto...já falei } \\
\text { várias vezes }\end{array}$ & PLANEJA \\
\hline 168 & ME & $\begin{array}{l}\text { então você espera que como você já trabalhou essa } \\
\text {...essa....adaptação você acha que essa sequência é } \\
\text { adequada ao seu grupo }\end{array}$ & QUESTIONA \\
\hline 169 & PR & $\begin{array}{l}\text { eu acho...eu acho que eles vão fazer o link...ah...porque tá } \\
\text { mais adaptada...entendeu...acho que sim }\end{array}$ & ACEITA \\
\hline 170 & ME & $\begin{array}{l}\text { certo...e você...tem alguma dificuldade assim...você acha } \\
\text { que tem alguma dúvida com relação ao problema ao } \\
\text { entendimento do problema...entendimento da situação } \\
\text { problema... }\end{array}$ & \\
\hline 171 & PR & não & \\
\hline 172 & ME & e da condução da discussão & \\
\hline 173 & PR & $\begin{array}{l}\text { não...de modo algum...eu só vô tê que me restringir a não } \\
\text { extrapolar dessa parte...porque eles vão querer discutir } \\
\text { muito a parte do avanço do mar nas cidades litorâneas eu } \\
\text { acho que eles vão querer ficar falando ali...e eu tenho que } \\
\text { já...é...direcionar a discussão pra uma área } \\
\text { preservada...que é o xis da questão...que a gente tá } \\
\text { tentando analisar o avanço do mar numa área preservada }\end{array}$ & PLANEJA \\
\hline 174 & ME & $\operatorname{sim}$ & \\
\hline 175 & $\mathbf{P R}$ & $\begin{array}{l}\text { e aí como eles vão primeiro ler um texto sobre a área já } \\
\text { ocupada acho que eles vão querer ficar discutindo muito } \\
\text { isso...porque é uma coisa próxima deles...é uma coisa que } \\
\text { realmente tá no noticiário...daí eu vô te que já conduzir a } \\
\text { discussão pra...ó...vamo analisar agora...numa área não } \\
\text { ocupada numa área preservada...que eles gostam disso...é } \\
\text { um assunto que chama atenção né... }\end{array}$ & PLANEJA \\
\hline 176 & ME & $\begin{array}{l}\text { quer dizer que cê acha que um ponto ali que ce vai te que } \\
\text { ter uma atenção é exatamente naquela transição onde a } \\
\text { gente pega o contexto do ambiente urbano e tenta fazer o } \\
\text { link pra questão preservada }\end{array}$ & QUESTIONA \\
\hline 177 & PR & exato & ACEITA \\
\hline 178 & ME & $\begin{array}{l}\text { então talvez um ponto pra se refletir bastante é aquelas } \\
\text { das imagens onde você tem... }\end{array}$ & \\
\hline 179 & PR & e...vamo olhar agora...vamo mudar...vamo analisar & PLANEJA \\
\hline 180 & ME & $\begin{array}{l}\text { se acontece isso em tal...como é que pode acontecer em } \\
\text { tal lugar }\end{array}$ & \\
\hline 181 & PR & $\begin{array}{l}\text { isso...é isso que nós vamos analisar...porque se não eles } \\
\text { vão ficar querendo conversar...ai porque o tsunami no } \\
\text { Japão é igual porque é o dia a dia...é o conhecimento que } \\
\text { tem na mídia... }\end{array}$ & PLANEJA \\
\hline
\end{tabular}




\begin{tabular}{|l|l|l|l|}
\hline $\mathbf{1 8 2}$ & ME & $\begin{array}{l}\text { quer dizer...esse é um outro ponto le...assim...legal de } \\
\text { observar...que antes de você permitir a resposta das } \\
\text { perguntas você faz essa questão e já coloca } \\
\text { aquela...aquele contexto...ó...não é um tsunami...não é }\end{array}$ & PLANEJA \\
\hline $\mathbf{1 8 3}$ & PR & isso...isso mesmo & QUESTIONA \\
\hline $\mathbf{1 8 4}$ & ME & cê acha que isso também é interessante & \\
\hline $\mathbf{1 8 5}$ & PR & é interessante & MODTIMULA \\
\hline $\mathbf{1 8 6}$ & ME & legal...tá...tem mais alguma observaçO & \\
\hline $\mathbf{1 8 7}$ & PR & não...entendi.... mais & \\
\hline $\mathbf{1 8 8}$ & $\mathbf{M E}$ & tá tranqüilo... & \\
\hline $\mathbf{1 8 9}$ & PR & tá tranqüilo não tenho dúvidas não & \\
\hline $\mathbf{1 9 0}$ & $\mathbf{M E}$ & então tá certo...então acho que é isso...tá bom? & \\
\hline $\mathbf{1 9 1}$ & $\mathbf{P R}$ & brigada \\
\hline
\end{tabular}


APÊNDICE 6 - ANÁLISE DA APLICAÇÃO DA SEQUÊNCIA DIDÁTICA

\begin{tabular}{|c|c|c|c|}
\hline \multicolumn{2}{|c|}{ EPISÓDIO 2 - ATIVIDADE 2} & \multirow{2}{*}{$\begin{array}{l}\text { vamo lá então...que que nós tínhamos então?nós tínhamos a elevação do nível do } \\
\text { mar...não é?numa área urbana...foi ou não foi?e a gente viu que com essa } \\
\text { elevação as cidades litorâneas vão sendo o que?...destruídas...aí a gente quer } \\
\text { saber agora se numa vegetação natural onde não tem o que?população...não tem } \\
\text { nada construído...não é?se como vai alterar essa vegetação...é esse o nosso } \\
\text { problema não é?e aí ela fez duas perguntas...se ela...se vocês acham que elas } \\
\text { vão...que se essa vegetação vai ser alterada...e como isso pode...que que vai } \\
\text { acontecer com ela...e se a vegetação não vai ser alterada...que que vai acontecer } \\
\text { com ela...cada um tem uma...opinião...é ou não é?e é isso que eu quero } \\
\text { mesmo...cada um tem que tê uma opinião sobre o problema...vamo estudá um } \\
\text { pouquinho mais esse problema...dá uma olhadinha na atividade dois...tá vendo } \\
\text { que tem um mapa da américa do sul? }\end{array}$} & \multirow{2}{*}{ DESCREVE } \\
\hline 01 & Pr & & \\
\hline $\mathbf{0 2}$ & A? & uhum & \\
\hline $\mathbf{0 3}$ & Pr & tá vendo? & \\
\hline 04 & As & $\operatorname{sim}$ & \\
\hline 05 & Pr & tá conseguindo ver? & \\
\hline 06 & As & $\operatorname{sim}$ & \\
\hline 07 & Pr & tá vendo que o estado...que estado que é esse que tá em negrito? & DESCREVE \\
\hline 08 & As & são paulo & \\
\hline 09 & Pr & $\begin{array}{l}\text { são paulo...o nosso estado não é?aí...esse estado de são paulo tá vendo que em } \\
\text { cima tem um quadradinho na parte no canto inferior aqui? }\end{array}$ & DESCREVE \\
\hline 10 & A? & tem & \\
\hline 11 & Pr & $\begin{array}{l}\text { tá vendo?esse canto então ele tá ampliado nesse quadrado pra gente poder } \\
\text { enxergar melhor...tá vendo?e esse quadradinho aqui do estado de são paulo é o } \\
\text { que tá ampliado embaixo...tão conseguindo entender? }\end{array}$ & DESCREVE \\
\hline 12 & A? & ahã & \\
\hline 13 & Pr & $\begin{array}{l}\text { sim?e qual que é essa região?essa região é região que fica no sul do estado de são } \\
\text { paulo que é a ilha do...cardoso...tá vendo?e essa região aqui é uma região costeira } \\
\text { que não é habitada...tá?....ao contrário de santos...que tem toda aquelas } \\
\text { construções aqui na ilha do cardoso ainda predomina a vegetação...natural }\end{array}$ & DESCREVE \\
\hline 14 & A? & só tem vegetação? & \\
\hline 15 & Pr & $\begin{array}{l}\text { só tem vegetação...tá vendo?e é essa...é esse lugar que nós vamos analisar } \\
\text { agora....deu pra entender onde a gente tá?então a gente pegou o mapa de são } \\
\text { paulo...selecionamos essa região sul que é a ilha do cardoso ela tá bem ampliada } \\
\text { aqui pra gente pode conseguir enxergar o local e esse quadradinho aqui...tá } \\
\text { vendo na ilha do cardoso?ele tá ampliado aqui em duas formas...ó de duas } \\
\text { maneiras...que é a figura a e a figura b...dá uma olhadinha na figura a...tá vendo a } \\
\text { praia? }\end{array}$ & DESCREVE \\
\hline 16 & As & $\{\operatorname{sim}\}$ & \\
\hline 17 & Pr & tá grossa a margem de areia...não tá? & DESCREVE \\
\hline 18 & As & tá & \\
\hline 19 & Pr & $\begin{array}{l}\text { não tá?bem espessa não tá?tem o mar a praia e embaixo da praia a vegetação...tá } \\
\text { bem branca essa faixa não tá? }\end{array}$ & DESCREVE \\
\hline 20 & $\mathbf{A 3}$ & a vegetação é maior & \\
\hline 21 & Pr & a vegetação?e a areia?que que cê acha da areia? & ORIENTA \\
\hline 22 & $\mathbf{A 2}$ & também é maior & DESCREVE \\
\hline 23 & A3 & também & \\
\hline 24 & $\operatorname{Pr}$ & é maior...é ou não é?...só um minutinho (...) & DESCREVE \\
\hline 25 & Pr & $\begin{array}{l}\text { agora dá uma olhadinha na figura b...depois de quinze anos...que foi tendo o } \\
\text { que?a aproximação do mar...dá uma olhadinha...que que aconteceu com a } \\
\text { margem de areia ela di... }\end{array}$ & DESCREVE \\
\hline 26 & A2 & mais fina & \\
\hline 27 & A1 & minuiu & DESCREVE \\
\hline 28 & Pr & bastante não é?tá mais estreita...e a vegetação? & \\
\hline 29 & A3 & diminuiu também & DESCREVE \\
\hline
\end{tabular}




\begin{tabular}{|c|c|c|c|}
\hline 30 & Pr & vamo dá uma olhada na vegetação...oi & \\
\hline 31 & A16 & ( ) afinou e foi algumas lá pro mar não foi? & \\
\hline 32 & Pr & isso vamo vê...vamo ve...ce acha que foi pro mar... & \\
\hline 33 & A16 & é...um pouco & \\
\hline 34 & Pr & é aí por que?a... & \\
\hline 35 & A? & ( ) & \\
\hline 36 & Pr & exatamente porque...o mar tá mais próximo da... & \\
\hline 37 & $\mathbf{A 2}$ & areia & \\
\hline 38 & Pr & ele levou um pouco da areia...não tá?a...a margem de areia ficou... & REINTERPRETA \\
\hline 39 & A2 & fina & \\
\hline 40 & A? & menor & \\
\hline 41 & Pr & $\begin{array}{l}\text { fina...não ficou?ficou menor...ele se aproximou da vegetação...não se } \\
\text { aproximou? }\end{array}$ & DESCREVE \\
\hline 42 & A? & $\operatorname{sim}$ & \\
\hline 43 & Pr & sim ou não? & \\
\hline 44 & As & $\{\operatorname{sim}\}$ & \\
\hline 45 & Pr & oi & \\
\hline 46 & A? & e lá também baixou um pouco & \\
\hline 47 & A11 & $\begin{array}{l}\text { pr!e lá também a areia tá se aproximando...é...tá coisando aqui ó na } \\
\text { vegetação...dentro }\end{array}$ & DESCREVE \\
\hline 48 & Pr & $\begin{array}{l}\text { tá? adentrando...ficando...isso! tá mostrando isso na figura...tá claro pra todo } \\
\text { mundo isso? que antes a gente tinha uma configuração...a gente tinha uma } \\
\text { margem de areia bem grande e agora essa...depois de quinze anos com a } \\
\text { aproximação do mar... }\end{array}$ & DESCREVE \\
\hline 49 & A? & o nível do mar diminuiu a areia & \\
\hline 50 & Pr & $\begin{array}{l}\text { a areia...isso mesmo...e agora essa...essa...essa margem de areia é menor...todo } \\
\text { mundo entendeu isso? }\end{array}$ & \\
\hline 51 & As & $\operatorname{sim}$ & \\
\hline 52 & Pr & ótimo...vira a página então... & \\
\hline 53 & A3 & ( ) a extensão da areia? & \\
\hline 54 & Pr & $\begin{array}{l}\text { isso...diminuiu a espessura de areia...não diminuiu?depois de quinze anos?vamo } \\
\text { vê em relação a vegtação...dá uma olhadinha...tá vendo essas bolinhas } \\
\text { vermelhas? }\end{array}$ & DESCREVE \\
\hline 55 & As & $\operatorname{sim}$ & \\
\hline 56 & Pr & $\begin{array}{l}\text { pontilhadas?dá uma olhadinha do lado tem uma legenda né a vegetação } \\
\text { herbácea...e essa parte que tem esse quadrado branco aqui na vegetação é a } \\
\text { vegetação... }\end{array}$ & DESCREVE \\
\hline 57 & As & arbustiva & \\
\hline 58 & Pr & $\begin{array}{l}\text { arbustiva...dá uma olhada...aqui tem duas fotos pra vocês terem um idéia de } \\
\text { como que é a vegetação é...herbácea e como que é a vegetação arbustiva...a } \\
\text { vegetação herbácea é mais rasteira...menor...tá vendo?e a arbustiva um pouco } \\
\text { maior...tá vendo isso?consegue...enxergar?ótimo...depois de quinze anos...olha o } \\
\text { que aconteceu com a vegetação?o pontilhado ele tá o que? }\end{array}$ & DESCREVE \\
\hline 59 & A13 & invadindo a vegetação...arbustiva & REINTERPRETA \\
\hline 60 & Pr & $\begin{array}{l}\text { perfeito...muito bem....ê tá vendo que essa pontilhada ele tá...invadindo a } \\
\text { vegetação... }\end{array}$ & REPRODUZ \\
\hline 61 & As & arbustiva & \\
\hline 62 & Pr & $\begin{array}{l}\text { né...então a gente viu que com a diminuição da espessura de areia a vegetação tá } \\
\text { se modificando não tá?onde a gente tinha uma vegetação herbácea depois } \\
\text { arbustiva a gente agora vê uma vegetação herbácea invadindo a... }\end{array}$ & REPRODUZ \\
\hline 63 & As & arbustiva & \\
\hline 64 & $\mathbf{A 1 3}$ & $($ () & \\
\hline 65 & Pr & $\begin{array}{l}\text { e esse é o nosso problema...por que?que condições que nós temos que permite } \\
\text { que a vegetação herbácea que antes ficava delimitada numa faixa...agora invada a } \\
\text { vegetação arbustiva? }\end{array}$ & DESCREVE \\
\hline 66 & A? & aproximação do mar & \\
\hline 67 & Pr & oi? & \\
\hline 68 & A? & a aproximação do mar? & \\
\hline 69 & Pr & a aproximação do mar?é não é?tem a...tem...influencia...a aproximação do mar & \\
\hline
\end{tabular}




\begin{tabular}{|c|c|c|c|}
\hline & & $\begin{array}{l}\text { agora tá criando o que?condições...não tá?que permita que essa vegetação } \\
\text { herbácea adentre e tome o espaço da vegetação arbustiva }\end{array}$ & REINTERPRETA \\
\hline 70 & $\mathbf{A 3}$ & arbustiva & \\
\hline 71 & & $\begin{array}{l}\text { e o por quê é o que vocês vão ter que responder...é esse o nosso problema...pra } \\
\text { ajudar a gente resolver esse problema a gente tem um texto de apoio que é esse } \\
\text { que tá...que eu entreguei pra vocês...tá escrito material de apoio... }\end{array}$ & DESCREVE \\
\hline 72 & A3 & ahã & \\
\hline 73 & Pr & tá vendo? & \\
\hline 74 & A? & tô & \\
\hline 75 & Pr & $\begin{array}{l}\text { que que esse material de apoio é?ele é uma caracterização...ele vai explicar como } \\
\text { que é a vegetação da restinga...certo?vamo lê junto pra ajudar a vocês } \\
\text { a....solucionar o problema...olha lá... "conhecendo a restinga....a restinga apresenta } \\
\text { um conjunto diversificado de vegetações que ocupam as } \\
\text { planícies...litorâneas"...lembra daquela figura um lá?da praia até as } \\
\text { montanhas...aquela vegetação rasteira que a gente viu?aquilo é a restinga... "as } \\
\text { vegetações possuem diferentes características a medidas que se distanciam do } \\
\text { mar"... ou seja... do mar até chegar lá na montanha vai tê o que } \\
\text { uma...modificação na vegetação... certo? }\end{array}$ & DESCREVE \\
\hline 76 & As & certo & \\
\hline 77 & Pr & $\begin{array}{l}\text { deu pra entender...uma refusão...refusão é quando... junta... é uma diferenciação } \\
\text { mesmo... plantas mais próximas do mar vai ter uma determinada característica... } \\
\text { plantas mais afastadas do mar vai ter uma... determinada }\end{array}$ & REINTERPRETA \\
\hline 78 & A? & outra característica & \\
\hline 79 & Pr & é exatamente...outras características & \\
\hline 80 & $\mathbf{A 1 3}$ & ( ) modificá né... o ambiente onde elas se encontram & \\
\hline 81 & Pr & $\begin{array}{l}\text { perfeito isso... deu pra entende?então as características variam de acordo com a } \\
\text { aproximação do mar e o distanciamento do mesmo... certo?nós vamo vê como } \\
\text { que é essa vegetação... "são influenciadas principalmente pelas condições... do } \\
\text { solo... drenagem da água... disponibilidade de nutrientes"... ou seja... a } \\
\text { disponibilidade da água próxima do mar vai ser diferente da disponibilidade mais } \\
\text { afastada... concorda? }\end{array}$ & DESCREVE \\
\hline 82 & As & $\operatorname{sim}$ & \\
\hline 83 & Pr & $\begin{array}{l}\text { e a disponibilidade de nutrientes também e fatores físicos como "o movimento } \\
\text { da areia... o vento... o atrito do grão de areia... o vento forte... a influência do } \\
\text { sol... a temperatura... a disponibilidade de água... a disponibilidade de sal... a } \\
\text { salinidade e outros... certo?então tudo isso vai interferir o que?nas características } \\
\text { da vegetação que a gente tem mais próximo do mar e que nós temos mais } \\
\text { afastadas do mar... deu pra entender? }\end{array}$ & DESCREVE \\
\hline 84 & As & deu & \\
\hline 85 & Pr & $\begin{array}{l}\text { ótimo... então vamo lá... agora nós vamos fazer uma viagem... descendo do mar } \\
\text { até chegar na planície... vamo vê... ó... "vamos imaginar que acabamos de } \\
\text { desembarcar em uma praia e seguimos em frente em direção a encosta... das } \\
\text { montanhas como indica a seta abaixo"... tá vendo? cê acabou de descer lá na } \\
\text { praia... cê vai chegar lá na montanha... ó... ce vai percorrer esse caminho... vamo } \\
\text { vê passo a passo como que é a vegetação... de quando a gente sai daqui do mar } \\
\text { até chegar na encosta... é isso que nós vamos ver agora... certo? vamo lá... } \\
\text { "saindo do mar... há alguns passos sobre a areia e fora da ação da... das marés } \\
\text { nos deparamos com uma vegetação rasteira... que chega a aproximadamente } \\
\text { quarenta centímetros de altura sobre o chão... são tufos de capim e plan... e } \\
\text { plantas de ramos muito finos e moles que crescem e se reproduzem } \\
\text { rapidamente...essa é a vegetação herbácea"... então essa vegetação é aquela } \\
\text { vegetação que nós vimos lá no problema... lembra?... ((os alunos ficam em } \\
\text { silêncio)) tava pontilhada de vemelha... é a primeira vegetação ao sairmos da } \\
\text { praia... mais próximo do mar... deu pra ver? localizaram ela?... ((silêncio)) } \\
\text { certo?então ela é o que?baixinha... rasteira né... não cresce muito... vamo virá a } \\
\text { página aqui... alá... a vegetação herbácea é essa vegetação... que tá marcada } \\
\text { pontilhada de vermelha lá na figura... ela “ possui raízes bastante profundas e } \\
\text { sistemas de raízes e rizomas que fixam as plantas na areia e as mantém mais } \\
\text { estáveis, já que a areia da praia se movimenta com mais facilidade devido ao }\end{array}$ & DESCREVE \\
\hline
\end{tabular}




\begin{tabular}{|c|c|c|c|}
\hline & & $\begin{array}{l}\text { vento... então cê tá vendo que essa planta tem o que? as adaptações corretas pra } \\
\text { poder viver ali... porque se elas estão mais próximas da areia... mais próximas do } \\
\text { mar... é importante que ela tenha o que? uma fixação melhor não é?por que? o } \\
\text { vento bate a areia move... movimenta... tá vendo que elas tem as características } \\
\text { certinho que permite elas viver naquela... naquele lugar?vamo lá... "esse tipo de } \\
\text { planta é de grande importância nesse ambiente... pois a areia fica aderida em suas } \\
\text { coroas"... ó...coroa tá marcado aí na setinha ao lado... tá vendo?... os tufinho?... } \\
\text { ((silêncio)) é no “emaranhado de suas raízes que dificulta que o vento carregue } \\
\text { grandes quantidades dessa areia em direção ao interior"... então a areia bate na } \\
\text { coroa e... fica... tá... fica presa... }\end{array}$ & DESCREVE \\
\hline 86 & $\mathbf{A 1 3}$ & ( ) é deve ser a função ( ) & \\
\hline 87 & Pr & $\begin{array}{l}\text { isso... isso mesmo... "suas folhas finas... longas e flexíveis são resistentes ao } \\
\text { vento forte dessa região e além disso possuem grande facilidade de regeneração } \\
\text { quando rompidas" ou seja se o vento quebra ela regenera com mais }\end{array}$ & DESCREVE \\
\hline 88 & A? & fácil & \\
\hline 89 & Pr & $\begin{array}{l}\text { facilmente... legal né? “outra planta que também vive nessa região é a salsa da } \\
\text { praia"... que é essa figura quatro aqui... tá vendo essa florzinha roxa?... ela } \\
\text { "possui folhas e hastes mais rígidas e espessas que protege contra a perda de } \\
\text { água contra o sal que chega com a maresia e também contra o desgaste } \\
\text { provocado pelo atrito dos grãos de areia... trazidos pelo vento"... então essa } \\
\text { planta tem outra característica que permite que ela vive ali... não é?que é o } \\
\text { que?ela possui as folhas e as hastes bem... durinhas rígidas... que protege elas } \\
\text { contra o que?a perda de água já que o sal ali que chega... a quantidade é maior } \\
\text { não é?... e aí também...é... e contra os desgastes provocado pelo que? pelo grão } \\
\text { de areia que tá sempre batendo nela... fala A22 }\end{array}$ & DESCREVE \\
\hline 90 & $\mathbf{A 2 2}$ & $\begin{array}{l}\text { não... eu ia falar que cada planta que ce leu até agora tá apropriada pra viver em } \\
\text { um lugar }\end{array}$ & EXPLICA \\
\hline 91 & Pr & isso & ACEITA \\
\hline 92 & A22 & $\begin{array}{l}\text { que tem características diferente porque que tá apropriada pra viver em um lugar } \\
\text { diferente }\end{array}$ & EXPLICA \\
\hline 93 & Pr & $\begin{array}{l}\text { perfeito... então elas tem as características adequadas praquele local... é ou não } \\
\text { é?vamo continuar lendo que nós vamos ver outros exemplos ó... “um exemplo } \\
\text { interessante é o cordeiro da praia... essa planta possui pêlos esbranquiçados que } \\
\text { refletem a luz do sol... protegendo-as... além disso também possui caule e folhas } \\
\text { suculentas que armazenam a água... certo?então é uma outra característica né?a } \\
\text { luminosidade ali perto da praia é maior...não é?então elas são branquinhas por } \\
\text { que elas refletem a luz solar... uma outra característica que permite que ela viva } \\
\text { ali naquele lugar... deu pra entender?... ó... "continuando o nosso percur... } \\
\text { percurso... após passar a vegetação herba... herbácea as plantas começam a ficar } \\
\text { mais altas e andar entre ela... e andar entre elas começa ficar difícil pois a } \\
\text { vegetação é mais... densa... é a vegetação arbustiva" que tá representado pela } \\
\text { figura sete... "que pode chegar a três metros de altura”... a vegetação arbustiva é } \\
\text { aquela que tá logo depois dos pontilhados vermelhos... lembra que tinha um } \\
\text { quadrado branco? já ( ) dessa vegetação... essa vegetação já apresenta outras } \\
\text { carcterísticas... ó... só pelo tamanho dá pra saber que ela é diferente... lembra } \\
\text { que a herbácea não passava de quarenta centímetros? a arbustiva tá com quantos } \\
\text { metros agora? }\end{array}$ & $\begin{array}{l}\text { ACEITA } \\
\text { DESCREVE }\end{array}$ \\
\hline 94 & As & três & \\
\hline 95 & Pr & $\begin{array}{l}\text { três e é mais densa... ou seja... mais fechada... certo?vamo dá uma estudada } \\
\text { nela... "essas plantas recebem menor influência do mar... ou seja do sal... da } \\
\text { salinidade e dos ventos... o terreno ele é mais estável"... lembra que lá era areia? } \\
\text { e que as plantas tinha que ter raízes fortes e rizomas pra elas poderem ficar fixas } \\
\text { lá... aqui não... aqui o solo ele " já é mais estável e as condições de fixação das } \\
\text { raízes das plantas melhoram"... né elas conseguem ficar mais fixas... } \\
\text { "dependendo da época do ano ocorre o acúmulo de água da chuva e ao contrário } \\
\text { da região onde predominavam as herbáceas existe sobre o solo da vegetação } \\
\text { arbustiva uma camada fina de serrapilheira"... que que é serrapilheira? são } \\
\text { "restos vegetais como folhas caules frutos e flores que entram em decomposição } \\
\text { e fornece o que pra planta? }\end{array}$ & DESCREVE \\
\hline 96 & A? & nutriente & \\
\hline 97 & Pr & nutrientes... né?aí tá a camadinha... nesse quadradinho preto selecionado tá a & \\
\hline
\end{tabular}




\begin{tabular}{|c|c|c|c|}
\hline & & $\begin{array}{l}\text { acamadinha do que? de serrapilheira... que é essa camada de nutrientes pra essa... } \\
\text { pra essa vegetação... "em seguida continuando o caminho em direção a encosta } \\
\text { das montanhas começam a aparecer árvores que podem chegar até VINTE } \\
\text { metros de altura }\end{array}$ & DESCREVE \\
\hline 98 & As & nossa & \\
\hline 99 & Pr & $\begin{array}{l}\text { olha a diferença... a gente tinha a vegetação de quarenta centímetros e agora nós } \\
\text { vamos ter plantas de quarenta metros de altura... né?e aí já é a floresta de } \\
\text { restinga... tá?”a mata começa a ficar mais fechada e o ambiente é bem mais... } \\
\text { úmido... há grande disponibilidade de nutrientes nessa região em comparação } \\
\text { com as anteriores... aqui podemos perceber que existem muitas espécies de } \\
\text { plantas diferentes e em grande quantidade... o inverso do que ocorre na região } \\
\text { das... praias onde há apenas poucas espécies adaptadas às condições daquele } \\
\text { ambiente... alguma dúvida em relação a vegetação que a gente tá encontrando da } \\
\text { hora que a gente sai do mar até chegar nas montanhas? }\end{array}$ & DESCREVE \\
\hline 100 & As & não & \\
\hline 101 & Pr & $\begin{array}{l}\text { não é? então que que a gente tem?a gente tem uma vegetação primeiro herbácea } \\
\text { depois arbustiva e depois essa floresta de restinga... né?e cada uma apresenta o } \\
\text { que?uma certa característica... então vamo voltá lá pro nosso problema... que que } \\
\text { nós temos?nós temos uma vege... uma... uma aproximação do mar... não } \\
\text { temos?diminuindo essa faixa de areia... não é?se tá diminuindo a faixa de areia } \\
\text { essa aproximação do mar tá chegando mais próximo de quem?da vegetação... } \\
\text { não tá?e aí nós te... tivemos o que? uma modificação na vegetação... antes a } \\
\text { vegetação herbácea que ficava delimitada só a encosta ela agora com a } \\
\text { aproximação do mar tá adentrando não tá?invadindo... exatamente... por que que } \\
\text { tá invadindo... que que ceis acham que tá acontecendo... e aí é o que vocês vão } \\
\text { escrever pra mim tá certo? (...) então vocês vão responder essa pergunta pra mim } \\
\text { aqui ó... na última folha... vô mostrar pra todo mundo pra não ficar perdido.... tá } \\
\text { vendo? um e dois?e aí eles tão fazendo a pergunta que é o seguinte ó... "por que } \\
\text { com a aproximação do mar a vegetação herbácea começa a aparecer com mais } \\
\text { frequiência onde antes predominava a vegetação arbustiva?como se deu esse } \\
\text { processo?”... é isso que vocês tem que responder tá bom?... certo?alguma } \\
\text { dúvida? }\end{array}$ & DESCREVE \\
\hline 102 & A6 & posso fazer um esquema... desenha aqui pra responder a um? & \\
\hline 103 & Pr & $\begin{array}{l}\text { ce qué... eu prefiria que você escrevesse... mas... se você quiser escrever e } \\
\text { desenhar... pode sim }\end{array}$ & \\
\hline 104 & $\mathbf{A 1 3}$ & eu não entendi essa dois.. como se deu esse processo & \\
\hline 105 & Pr & $\begin{array}{l}\text { é... por que você acha que a vegetação herbácea foi invadindo... por que que ela } \\
\text { conseguiu invadir?que aconteceu com a vegetação arbustiva?..... cê tá com } \\
\text { dúvida ainda? }\end{array}$ & DESCRIÇÃO \\
\hline 106 & $\mathbf{A 1 3}$ & uhum & \\
\hline 107 & Pr & $\begin{array}{l}\text { ó... é assim ó... a aproximação do mar você já falou que ela já altera a } \\
\text { vegetação... não alterou?e a gente viu que a vegetação herbácea começou a } \\
\text { invadir a vegetação arbustiva não foi?aqui eles tão falando assim... por que que } \\
\text { você acha... como que ela conseguiu invadi?o que será que deve tê acontecido } \\
\text { com a vegetação arbustiva... o que será que aconteceu com essa vegetação } \\
\text { arbustiva pra que com.. pra que a vegetação herbácea conseguisse tomar o lugar } \\
\text { dela?que ce acha que aconteceu com ela? }\end{array}$ & ORIENTA \\
\hline 108 & $\mathbf{A 1 3}$ & tá & \\
\hline 109 & Pr & entendeu? & \\
\hline 110 & $\mathbf{A 1 3}$ & entendi & \\
\hline 111 & A? & e a dois? & \\
\hline 112 & A2 & foi o que ela acabou de explicar & \\
\hline 113 & Pr & $\begin{array}{l}\text { foi isso que eu falei... mas ó... vamo de novo...ó... aqui existia uma vegetação } \\
\text { herbácea... não tinha?que agora depois do avanço do mar a gente viu que ela } \\
\text { começou a invadir o lugar da outra vegetação... a arbustiva... não é?a gente quer } \\
\text { saber o por que ela conseguiu invadir... se ela conseguiu invadir... como ela } \\
\text { conseguiu?por que que ela conseguiu invadir? que que ela fez?que que aconteceu } \\
\text { com a vegetação arbustiva... que que ce acha que aconteceu com a vegetação } \\
\text { arbustiva que cedeu o lugar pra herbácea ocupar o lugar dela? }\end{array}$ & ORIENTA \\
\hline 114 & $\mathbf{A 2 2}$ & $($ ) & \\
\hline
\end{tabular}




\begin{tabular}{|c|c|c|c|}
\hline 115 & Pr & se você pode falar a resposta?... então fala só pra mim & \\
\hline 116 & $\mathbf{A 2 2}$ & $\begin{array}{l}\text { por que que a herbácea tomou o lugar dela?... por que o nível do mar aumento e é } \\
\text { característica dela viver naquele lugar perto do mar }\end{array}$ & EXPLICA \\
\hline 117 & Pr & perfeito... isso mesmo... escreve isso pra mim... certinho... & ACEITA \\
\hline 118 & $\mathbf{A 3}$ & não entendi a um & \\
\hline 119 & Pr & $\begin{array}{l}\text { não entendeu a um?... vamo lá de novo ó... por que que... a gente viu que o mar } \\
\text { aproximou... a faixa de areia ficou mais... }\end{array}$ & ORIENTA \\
\hline 120 & $\mathbf{A 3}$ & extensa & \\
\hline 121 & Pr & estreita & \\
\hline 122 & A1 & estreita & \\
\hline 123 & Pr & né?... estreita... menor... não é?mais fino... não é?é ou não é? & \\
\hline 124 & $\mathbf{A 1}$ & é & \\
\hline 125 & & $\begin{array}{l}\text { e aí a gente viu que aconteceu o que com a vegetação?a vegetação herbácea que } \\
\text { antes ocupava só uma faixinha... ela começou o que?ela começou a... invadir... } \\
\text { não começou?a tomar o lugar da vegetação arbustiva... por que que vocês acham } \\
\text { que isso aconteceu?analisando aquele texto de apoio que a gente leu... que } \\
\text { característica tem a planta herbácea que permitiu que ela adentrasse assim e que } \\
\text { característica tem a arbustiva que permitiu que ela o que?não resistisse aquele } \\
\text { lugar... aque... aquela condição que agora ela tava presenciando?deu pra } \\
\text { entender? }\end{array}$ & ORIENTA \\
\hline 126 & A3 & é mais ou menos... & \\
\hline 127 & Pr & $\begin{array}{l}\text { é pra vocês grifarem o texto de apoio... o que que vocês utilizaram pra escrever... } \\
\text { pra responder }\end{array}$ & \\
\hline 128 & $\mathbf{A 1 3}$ & () & \\
\hline 129 & Pr & ( ) $\operatorname{sim} . .$. pode por & \\
\hline 130 & A2 & $\begin{array}{l}\text { pf... aqui ó... tãnanana ((aluna simula leitura e aponta trecho do texto de apoio)) } \\
\text { pode escrever isso? }\end{array}$ & \\
\hline 131 & Pr & cê tá usando isso pra responder? & \\
\hline 132 & A2 & é & \\
\hline 133 & Pr & então você grifa pra mim só... só que... & \\
\hline 134 & A2 & dá uma... & \\
\hline 135 & Pr & $\begin{array}{l}\text { isso... cê vai grifar pra mim o que que você tá usando pra responder a pergunta, } \\
\text { né?por que com a aproximação do mar a vegetação herbácea começou a invadir } \\
\text { né... o lugar onde predominava a outra... e aí se você usar isso aqui re... ajudar a } \\
\text { formular sua resposta você grifa pra mim }\end{array}$ & DESCREVE \\
\hline 136 & A3 & não tô conseguindo & \\
\hline 137 & Pr & $\begin{array}{l}\text { não tá conseguindo... vamo lá... o que a gente tinha antes?a gente tinha uma faixa } \\
\text { de areia muito... }\end{array}$ & ORIENTA \\
\hline 138 & A3 & grande & \\
\hline 139 & Pr & E aí o mar veio se aproximando e a faixa de areia ficou... & ORIENTA \\
\hline 140 & A3 & menor & \\
\hline 141 & Pr & menor... é ou não é? & \\
\hline 142 & $\mathbf{A 3}$ & é & \\
\hline 143 & Pr & $\begin{array}{l}\text { diminuiu a areia e o que aconteceu com a vegetação... quando a areia era } \\
\text { espessa... grande aqui a vegetação arbustiva ficava localizada aqui não é? bem } \\
\text { próximo do mar... não é?e a vegetação arbustiva tomava esse espaço aqui } \\
\text { certo?quando a diminuição da areia diminuiu... só um minutinho ((outro aluno } \\
\text { chama a professora)) com a diminuição da faixa de areia diminuiu o que } \\
\text { aconteceu com a vegetação arbustiva?ela começou a se... espalhar e a vegetação } \\
\text { arbustiva? }\end{array}$ & ORIENTA \\
\hline 144 & A3 & dominou tudo & \\
\hline 145 & Pr & $\begin{array}{l}\text { a vegeta... essa é a herbácea... não... essa vegetação herbácea começou } \\
\text { predominar tudo... e a vegetação arbustiva?cade ela? }\end{array}$ & ORIENTA \\
\hline 146 & $\mathbf{A 3}$ & ela sumiu & \\
\hline 147 & Pr & sumiu... pra onde ela foi? & ORIENTA \\
\hline 148 & A1 & foi embora & \\
\hline 149 & Pr & ela já não existe mais onde ela... & \\
\hline 150 & $\mathbf{A 3}$ & existia & \\
\hline
\end{tabular}




\begin{tabular}{|c|c|c|c|}
\hline 151 & Pr & existia & \\
\hline 152 & A2 & ela foi existir em outro lugar... não é & \\
\hline 153 & Pr & $\begin{array}{l}\text { por que com a aproximação do mar essa vegetação começou a ( ) o que propiciou } \\
\text { essa aproximação do mar... que características que propiciou... é... esse avanço } \\
\text { aqui do mar propiciou o que?pra essas vegetação aqui deu condições o que pra } \\
\text { essa vegetação herbácea podê... é... se }\end{array}$ & ORIENTA \\
\hline 154 & A1 & espalhar & \\
\hline 155 & Pr & expandir... isso... que que ela fez com a vegetação arbustiva? & ORIENTA \\
\hline 156 & A2 & destruiu? & \\
\hline 157 & Pr & quais são as carac & \\
\hline 158 & A3 & que... é... o mar... fez... não & \\
\hline 159 & Pr & $\begin{array}{l}\text { ó... é... por que que a vegetação herbácea depois que aproximou mais do mar ele } \\
\text { conseguiu o que?ela conseguiu se espalhar?quais são as características das... da... } \\
\text { quais são as características de uma planta herbácea? }\end{array}$ & ORIENTA \\
\hline 160 & A3 & raízes fortes & REINTERPRETA \\
\hline 161 & Pr & $\begin{array}{l}\text { isso... aí ela consegue viver melhor... não consegue?tá mais próximo do mar... e a } \\
\text { região... e a vegetação arbustiva? }\end{array}$ & $\begin{array}{l}\text { ACEITA } \\
\text { ORIENTA }\end{array}$ \\
\hline 162 & $\mathbf{A 3}$ & ela não consegue & \\
\hline 163 & Pr & por que que ela não consegue? & ORIENTA \\
\hline 164 & A1 & por que ela não é forte & REPRODUZ \\
\hline 165 & Pr & é forte que fala? & ORIENTA \\
\hline 166 & $\mathbf{A 3}$ & ah não é forte ((aluna procura no texto)) & \\
\hline 167 & Pr & ó... aqui fala da vegetação arbustiva & \\
\hline 168 & $\mathbf{A 3}$ & ( ) ((aluna começa a ler onde aponta a professora)) & \\
\hline 169 & Pr & a arbustiva é preparada pra viver mais próximo do mar? & ORIENTA \\
\hline 170 & A3 & não... ela vive num lugar mais assim... longe da água & EXPLICA \\
\hline 171 & Pr & $\begin{array}{l}\text { isso... tem características pra poder viver mais longe da água... ela tem } \\
\text { característica pra viver mais perto do mar?por que que cê acha que a vegetação } \\
\text { herbácea começou a invadir a arbustiva? }\end{array}$ & ORIENTA \\
\hline 172 & A3 & porque a... como que chama... a & \\
\hline 173 & Pr & herbácea & \\
\hline 174 & $\mathbf{A 3}$ & herbácea ela tem mais predominância de ficar mais perto do mar e essa não & EXPLICA \\
\hline 175 & Pr & escreve aqui pra mim & \\
\hline 176 & Pr & quem me chamou?peraí... só um minutinho... & \\
\hline 177 & A7 & ( ) & \\
\hline 178 & Pr & vamo saí pro intervalo e qdo volta a gente continua escrevendo & \\
\hline
\end{tabular}

\begin{tabular}{|c|c|c|c|}
\hline \multicolumn{2}{|c|}{ EPISÓDIO 3 - ATIVIDADE 2} & \multirow{2}{*}{$\begin{array}{l}\text { vamo continuar agora a resolver o nosso problema... antes de sair do intervalo o } \\
\text { que que eu tinha deixado pra vocês?a gente tinha que resolver um problema não } \\
\text { é? que problema era esse?a gente tinha o que?a gente tinha uma faixa de areia } \\
\text { bem grossa bem espessa... não é?que depois de quinze anos ficou o que? }\end{array}$} & \multirow{2}{*}{ DESCREVE } \\
\hline 01 & Pr & & \\
\hline 02 & A? & menor & \\
\hline 03 & Pr & $\begin{array}{l}\text { fina...não foi?pequena...não foi?a vegetação quando essa faixa de areia era bem } \\
\text { grossa ela ocupava uma determinada região... o que tava pontilhada de } \\
\text { vermelho...é ou não é? }\end{array}$ & DESCREVE \\
\hline 04 & As & é & \\
\hline 05 & Pr & $\begin{array}{l}\text { quando essa vegeta...quando esse...essa camada de areia diminuiu esse } \\
\text { pontilhado vermelho que que ele fez...ele se....alastrou não é?ele ocupou a área } \\
\text { que antes tinha uma vegetação... }\end{array}$ & DESCREVE \\
\hline 06 & A? & arbustiva & \\
\hline 07 & Pr & arbustiva...é ou não é?e qual era o problema que a gente tinha pra resolver?por & \\
\hline
\end{tabular}




\begin{tabular}{|c|c|c|c|}
\hline & & $\begin{array}{l}\text { que que essa vegetação herbácea conseguiu invadir e ocupar o espaço da } \\
\text { vegetação arbustiva?como que elas conseguiram fazer isso?que é a pergunta dois } \\
\text { como se deu esse processo...que que vocês acham?pra gente solucionar o } \\
\text { problema a gente tinha aquele material de apoio lembra?que que era o material } \\
\text { de apoio?era o material que explicava as características da vegetação não } \\
\text { é?desde quando a gente sai do mar...né...até aonde a gente chega nas } \\
\text { montanhas...toda a planície...e nós vimos que essa vegetação foi o que? se mo... }\end{array}$ & DESCREVE \\
\hline 08 & A? & dificando... & \\
\hline 09 & Pr & $\begin{array}{l}\text { modificando...é ou não é?não vai se modificando?conforme ela vai se afastando } \\
\text { do mar...é ou não é?ela vai se alterando tendo características o } \\
\text { que?diferentes...deu pra entender?alguém tá com dúvida pra responder?...então } \\
\text { podem responder }\end{array}$ & DESCREVE \\
\hline 10 & A? & eu tô com pouquinho na dois & \\
\hline 11 & Pr & $\begin{array}{l}\text { na dois?ó...a dois tá falando o seguinte a vegetação herbácea que é aquela do } \\
\text { pontilhado vermelho invadiu...não invadiu?ela tomou o espaço...como que ela } \\
\text { conseguiu tomar esse espaço?que que a vegetação herbácea tem que permite que } \\
\text { quando o mar chegue mais próximo dela que foi o que aconteceu...ela permite o } \\
\text { que...se expandir tomar uma área maior?que que a vegetação arbustiva tem que } \\
\text { não permitiu que ela conseguisse o que ficar ali naquela área?deu pra entender ou } \\
\text { tá com dúvida ainda?...então tá bom...vamo respondê...depois nós vamos discutir }\end{array}$ & DESCREVE \\
\hline 12 & $\mathbf{A 3}$ & $\operatorname{Pr} .$. & \\
\hline 13 & Pr & oi & \\
\hline 14 & $\mathbf{A 3}$ & ( ) espécie....é espécie? & \\
\hline 15 & Pr & $\begin{array}{l}\text { vegetação herbácea...a gente tá falando de vegetação herbácea.... vegetação } \\
\text { herbácea tem várias espécies diferentes...lembra?vê lá no material de apoio... a } \\
\text { gente tinha a salsa da praia o cordeiro da praia... }\end{array}$ & \\
\hline 16 & A2 & ( ) & \\
\hline 17 & Pr & herbácea conseguiu invadir a vegetação arbustiva... & \\
\hline 18 & A2 & a arbustiva foi destruída e ( ) & \\
\hline 19 & Pr & e por que a vegetação arbustiva foi destruída?por que ela não tá mais lá? & \\
\hline 20 & $\mathbf{A 2}$ & depois eu te falo... & \\
\hline 21 & A18 & $($ ) & \\
\hline 22 & Pr & $\begin{array}{l}\text { ó a gente tem o mar aqui tá vendo...ele ficou mais próximo aqui...( ) mais } \\
\text { fino...com isso olha o que aconteceu com a vegetação...a vegetação herbácea que } \\
\text { ficava só nessa região ela começou a invadir toda essa vegetação...o que tinha } \\
\text { antes aqui?qual que era a vegetação que tinha antes? }\end{array}$ & DESCREVE \\
\hline 23 & A18 & arbustiva & \\
\hline 24 & Pr & $\begin{array}{l}\text { arbustiva...e agora a gente tem o que?vegetação herbácea no lugar da vegetação } \\
\text { arbustiva...por que que será que essa vegetação herbácea conseguiu tomar o lugar } \\
\text { da vegetação arbustiva? dá uma olhada no material de apoio...quais as } \\
\text { características dessas duas vegetações?a vegetação herbácea agora ela tá mais } \\
\text { próxima do mar não tá?a vegetação arbustiva com a diminuição da espessura da } \\
\text { areia ela ficou mais próxima do mar não ficou? o que será que aconteceu com } \\
\text { ela?ela tá nessa região?só um minutinho... }\end{array}$ & DESCREVE \\
\hline 25 & A16 & ( ) & \\
\hline 26 & Pr & $\begin{array}{l}\text { a dois tá falando assim ó...a gente sabe que a vegetação herbácea começou a } \\
\text { invadir o local que antes era da arbustiva...ele quer saber o por que? }\end{array}$ & \\
\hline 27 & A14 & ( ) & \\
\hline 28 & Pr & $\begin{array}{l}\text { ó pessoal pensa nas características agora que a gente tem o mar bem mais } \\
\text { próximo com a diminuição da espessura de areia o mar se aproximou mais da } \\
\text { vegetação arbustiva não se aproximou?como que é essa vegetação arbustiva?ela } \\
\text { tem características que permitiam ela ficar mais próxima do mar? né...vamo } \\
\text { pensa nas características... }\end{array}$ & ORIENTA \\
\hline 29 & $\mathbf{A 3}$ & () & \\
\hline 30 & Pr & $\begin{array}{l}\text { ó...a gente sabe que a aproximação do mar fez com que a vegetação herbácea } \\
\text { invadisse o lugar da arbustiva...é ou não é?como que ela conseguiu invadir? }\end{array}$ & ORIENTA \\
\hline 31 & $\mathbf{A 3}$ & onde tá escrito? & \\
\hline 32 & Pr & não não tá escrito...você tem que formular...ce tem que resolver o & \\
\hline
\end{tabular}




\begin{tabular}{|c|c|c|c|}
\hline & & $\begin{array}{l}\text { problema...né...e aqui você tem o material de apoio...pra apoiar você a } \\
\text { responder...gente ((se volta para a sala toda)) vocês não vão achar uma resposta } \\
\text { pronta no texto...né...vocês vão ter que construir...né...resolver o } \\
\text { problema...vocês vão construir sua resposta com a ajuda do texto certo? }\end{array}$ & ORIENTA \\
\hline 33 & $\mathbf{A 3}$ & $($ ) & \\
\hline 34 & Pr & $\begin{array}{l}\text { ó...a gente sabe que a vegetação herbácea... ó...com a espessura bem próxima do } \\
\text { mar ela ficava aqui não ficava?quando essa espessura diminuiu o mar se } \\
\text { aproximou e ela conseguiu invadir e tomar o lugar da vegetação arbustiva...que } \\
\text { característica tem uma planta herbácea?que cara... }\end{array}$ & ORIENTA \\
\hline 35 & A3 & ela tem as raízes... & \\
\hline 36 & Pr & isso...tem as raízes o que? & ORIENTA \\
\hline 37 & A3 & fortes & REPRODUZ \\
\hline 38 & Pr & $\begin{array}{l}\text { que pode fixar...não é?que características tem as plantas arbustivas uma planta } \\
\text { arbustiva com as características que ela tem ela consegue sobreviver num lugar } \\
\text { mais próximo do mar?e a planta herbácea...ela é mais apropriada...ela } \\
\text { consegue?tenta resolver o problema nesse sentido }\end{array}$ & ORIENTA \\
\hline 39 & A? & $($ ) & \\
\hline 40 & Pr & ( ) & \\
\hline 41 & Pr & quem terminou?...quem não terminou? & \\
\hline 42 & A3 & não Pr...vem aqui & \\
\hline 43 & Pr & oi & \\
\hline 44 & $\mathbf{A 3}$ & $\begin{array}{l}\text { pr olha... nesse negocinho aqui ó... eu peguei e falei assim ó...coloquei porque a ( } \\
\text { ) arbustiva... }\end{array}$ & \\
\hline 45 & Pr & $($ ) & \\
\hline 46 & A3 & não é não & \\
\hline 47 & Pr & arbustiva é também ( ) & \\
\hline 48 & $\mathbf{A 3}$ & não... é essa daqui que eu quero colocar & \\
\hline 49 & Pr & então é herbácea... não é arbustiva & \\
\hline 50 & A3 & ahh & \\
\hline 51 & Pr & quer escrever herbácea? & \\
\hline 52 & A3 & é... é que eu escrevi errado & \\
\hline 53 & Pr & ela escreveu arbustiva com $\mathrm{H}$ & \\
\hline 54 & A3 & como que é? herbácea? & \\
\hline 55 & Pr & uhum & \\
\hline 56 & $\mathbf{A 3}$ & $\begin{array}{l}\text { ó pr... porque a herbácea foi mais apropriada para viver em lugar próximo ao mar } \\
\text { por ter as raízes bastante profunda e sistema das raízes é em rizomas que fixa as } \\
\text { plantas na areia e mantém as herbácea mais estáveis }\end{array}$ & EXPLICA \\
\hline 57 & Pr & bom... muito bom & ACEITA \\
\hline 58 & Pr & quem não terminou ainda?...quem não terminou? vou recolher então... & \\
\hline
\end{tabular}




\section{ANEXO 1 - TEXTOS DOS ALUNOS}

\begin{tabular}{|c|c|c|c|}
\hline ALUNO & $\begin{array}{l}\text { (1) A vegetação não é afetada, pois... } \\
\text { Se a aproximação do mar não afeta a } \\
\text { vegetação, então esperamos que... } \\
\text { (2) A vegetação pode ser afetada, pois... } \\
\text { Se a aproximação do mar afeta a vegetação, } \\
\text { então esperamos que... }\end{array}$ & $\begin{array}{l}\text { 1. Por que, com a aproximação do mar, a vegetação } \\
\text { herbácea começou a aparecer com mais } \\
\text { freqüência onde antes predominava a vegetação } \\
\text { arbustiva? } \\
\text { 2. Como se deu esse processo? }\end{array}$ & GRIFO \\
\hline 1 & $\begin{array}{l}\text { (2)... afunda a vegetação, nos não vamos poder respirar } \\
\text { pois vamos perder muito oxigênio } \\
\text {... morremos pois vamos perder oxigênio }\end{array}$ & $\begin{array}{l}\text { 1. Porque a vegetação herbácea possui raízes fortes e bastante } \\
\text { resistente. E como o crescmento do mar de } 4 \mathrm{~mm} \text { vai cresente } \\
\text { 2.Com as raízes fortes as plantas herbáceas começam a } \\
\text { invadir, porque as plantas arbustiva não são fortes e as plantas } \\
\text { herbácea invadem muito facio. }\end{array}$ & $\begin{array}{l}\text { A vegetação herbácea possui } \\
\text { raízes bastante profundas }\end{array}$ \\
\hline 2 & $\begin{array}{l}\text { (2)... pois o nível de água é muito alto } \\
\ldots \text { as vegetação possa morrer mas espero que nasce em } \\
\text { outro lugar }\end{array}$ & $\begin{array}{l}\text { 1. Porque a vegetação herbácea tem raízes mais fortes, raízes } \\
\text { bastantes profundas e a vegetação arbustiva tem raízes mais } \\
\text { fracas e também fica mais longe da água } \\
\text { 2.Foi quando a vegetação arbustiva foi “destruída", e assim a } \\
\text { vegetação herbácea entrou em ação. A vegetação arbustiva } \\
\text { não vive em perto de água, assim o mar foi chegando perto da } \\
\text { vegetação, assim ela começou a assumir. Porque ela tem } \\
\text { raízes frágil, elas não são forte. }\end{array}$ & Sem grifo \\
\hline 3 & $\begin{array}{l}\text { (2)... se elas forem desmatada não iremos ter oxigênio } \\
\text { para respirar e iremos morrer } \\
\ldots\end{array}$ & $\begin{array}{l}\text { 1. Porque a nivi água do mar subiu e deu mais } \\
\text { sobrevivência para a vegetação herbácea } \\
\text { 2. Porque a herbácea foi mas apropriada para vivir em } \\
\text { lugar próximo au mar por ter as raises bastante } \\
\text { profunda e o sistema das raízes é um rizomas e que }\end{array}$ & $\begin{array}{l}\text { A vegetação herbácea possui } \\
\text { raízes bastante profundas e } \\
\text { sistemas de raízes e rizomas } \\
\text { (fig.3) que fixam as plantas }\end{array}$ \\
\hline
\end{tabular}




\begin{tabular}{|c|c|c|c|}
\hline & & $\begin{array}{l}\text { fixa as plantas na areia e mantenas herbácea mais } \\
\text { estaveis. }\end{array}$ & $\begin{array}{l}\text { na areia e as mantém mais } \\
\text { estáveis, já que a areia da } \\
\text { praia se movimenta com } \\
\text { muita facilidade. }\end{array}$ \\
\hline 4 & $\begin{array}{l}\text { (2)... sim, ela pode pois o mar pode causar muitas } \\
\text { diferente abitar natural } \\
\ldots \text { se ela afeta a vegetação então a vegetação vai ser } \\
\text { destruída com forme a água vai bater, e vai cada vez } \\
\text { mais destruindo o lugar }\end{array}$ & $\begin{array}{l}\text { 1. Ela a vegetação arbustiva ela não e preparado para } \\
\text { viver perto do mar. Agora a vegetação herbácea ela já } \\
\text { é preparada para isso. } \\
\text { 2. Porque a herbácea elas são mais fortes e consegue } \\
\text { viver mais prosimo ao mar. Porque tem raízes fortes }\end{array}$ & Sem grifo \\
\hline 5 & $\begin{array}{l}\text { (2)... com o volume da água subindo aus poucos pode } \\
\text { chegar na raiz da planta e apodrece-la. } \\
\ldots \text { apodrecimento e com pouca produção de gás } \\
\text { carbônico. }\end{array}$ & $\begin{array}{l}\text { 1. pois seu espaço esta sendo coberto pelo avanço do } \\
\text { mar. } \\
\text { 2. pois a planta arbustiva não tem características para } \\
\text { viver perto do mar, então ela acaba morrendo e a } \\
\text { planta herbácea toma seu espaço }\end{array}$ & Sem grifo \\
\hline 6 & $\begin{array}{l}\text { (2)... essa mudança gradativa tem condição de se } \\
\text { aproximar a área em que se localiza a vegetação } \\
\text {... esta alteração diminua, resumindo as fontes do } \\
\text { aquecimento global, pos a vegetação pode ser } \\
\text { prejudicada, não sendo adaptada a sobreviver em água } \\
\text { (como vegetação de manges) }\end{array}$ & $\begin{array}{l}\text { 1. Esquema } \\
\text { 2. Isso acontece porque a vegetação herbácea tem uma } \\
\text { capacidade forte para se adequar a área costeira } \\
\text { devida suas características. } \\
\text { A vegetação sente a presença do mar mais focada, } \\
\text { esse nível do mar paça a atingir também a vegetação } \\
\text { arbustiva, da qual nececitados nutrientes encontrados } \\
\text { na serrapilheira. A serrapilheira passa a se tornar } \\
\text { auzente devido a força do vento, a umidade, a } \\
\text { temperatura e outras coisa causadas pelo avanço do } \\
\text { nível do mar, assim a vegetação arbustiva vai se } \\
\text { degradando, liberando pocibilidade para a harbustiva } \\
\text { se reproduzir, pos suas características se adequam as } \\
\text { características formadas pela presença do mar. } \\
\text { Obs: Os animais se encontram com mais frequiência } \\
\text { na vegetação arbustiva, com a degradação da mesma, } \\
\text { várias expecies se sentem com dificuldade para } \\
\text { manter-se no local, assim precisam se deslocar em } \\
\text { busca de vida e alimento, muitos acabam morrendo. }\end{array}$ & Sem grifo \\
\hline 7 & $\begin{array}{l}\text { (2)...sim,por que o mar vai almentar pouco a pouco } \\
\text {... o almento do mar vai devagar mas vai devastar tudo }\end{array}$ & $\begin{array}{l}\text { 1. Por que na parte que a herbácea ficava foi empurrado } \\
\text { com a água e foi aparecendo na parte arbustiva na }\end{array}$ & \\
\hline
\end{tabular}




\begin{tabular}{|c|c|c|c|}
\hline & da vegetação com a água vai alagar tudo & $\begin{array}{l}\text { onde a vegetação herbácea fica foi sedevastano com } \\
\text { o mar, o mar foi almentando a água } \\
\text { 2. O processo, e que o mar almenta sobre } 4 \mathrm{~mm} \text { dagua e } \\
\text { vai alagando pates da prai e o lugar todo vai se alagar } \\
\text { pouco a pouco com a água. }\end{array}$ & Sem grifo \\
\hline 8 & $\begin{array}{l}\text { (1)... a vegetação pode ser afetada. } \\
\text {... não vai afetar } \\
\text { (2)... se o nível do mar subir sim } \\
\text {... sim porque não podemos fazer nada }\end{array}$ & $\begin{array}{l}\text { 1. Porque o mar tomou tudo e destruiu a vegetação } \\
\text { arbustiva } \\
\text { 2. Com o mar }\end{array}$ & Sem grifo \\
\hline 9 & $\begin{array}{l}\text { (1)... não, As pessoas não estão desmatano o nosso pais } \\
\ldots \text { Em tão nois não tevemos nos preocuparmos } \\
\text { (2)... sim, tem algumas pessoas que está desmadano } \\
\text { naturesa } \\
\ldots \text { quanto o mar subir mais pode ser que ele adija a } \\
\text { cidade }\end{array}$ & $\begin{array}{l}\text { 1. Porque a areia ficou mais fina quando o mar foi se } \\
\text { aproximando } \\
\text { 2. Pelo mar ou pela areia }\end{array}$ & Sem grifo \\
\hline 10 & $\begin{array}{l}\text { (2)... ela se destrói toda } \\
\text {... a vegetação não afeta e nem morre }\end{array}$ & $\begin{array}{l}\text { 1. Porque a vegetação herbácea tem mais condições de } \\
\text { viver perto do mar. } \\
\text { 2. Porque a vegetação herbácea possui raízes bastante } \\
\text { profundas e sistemas de raízes e rizomas que fixam } \\
\text { as plantas na areia e as mantem mais estáveis. Já a } \\
\text { vegetação arbustiva ela não consegui viver perto do } \\
\text { mar. }\end{array}$ & $\begin{array}{l}\text { A vegetação herbácea possui } \\
\text { raízes bastante profundas e } \\
\text { sistemas de raízes e rizomas } \\
\text { que fixam as plantas na areia } \\
\text { e as mantem mais estáveis }\end{array}$ \\
\hline 11 & $\begin{array}{l}\text { (2)... com o avanço do mar estas áreas seram invadidas } \\
\text { pela água. } \\
\text {... essas areias seram imundadas destruindo a vegetação } \\
\text { predominantes. }\end{array}$ & $\begin{array}{l}\text { 1. Porque com o avamço do mar elas não tem área, para } \\
\text { ficar e com isso elas acabam invadindo a área onde } \\
\text { predominava a vegetação arbustiva, se o mar } \\
\text { continuar avançando a vegetação arbustiva vai ter } \\
\text { que invadir a vegetação da floresta de restinga como } \\
\text { ela não é adapitada aquele lugar ela corre risco de ser } \\
\text { extinta. } \\
\text { 2. O mar avançou e a areia ficou molhada e um pouco } \\
\text { dura as plantas da vegetação herbácea não tem } \\
\text { características para se adaptar e sobreviver nesse } \\
\text { local, portanto ela vai para um lugar longe do mar } \\
\text { onde a areia não seja dessa forma cuja suas } \\
\text { características se adaptam. }\end{array}$ & Sem grifo \\
\hline 12 & (1)... uma característica afetada & 1. $12=$ pelo processo de organização da vegetação & \\
\hline
\end{tabular}




\begin{tabular}{|c|c|c|c|}
\hline & $\begin{array}{l}\text {... sim porque afetado ( ) } \\
\text { (2)... sim por que é vege } \\
\ldots \text { uma ( ) }\end{array}$ & 2. $\mathrm{R}=1889$ & Sem grifo \\
\hline 13 & $\begin{array}{l}\text { (2)... acaba causando a inundação de uma certa área, } \\
\text { mesmo com a demora de anos e modificando o ambiente } \\
\ldots \text { as matas podem ser destruídas, se as árvores não } \\
\text { forem adaptadas a esse certo meio podem acabar a } \\
\text { maioria morrendo e causando modificações no ambiente } \\
\text { e não tendo local para se reproduzir }\end{array}$ & $\begin{array}{l}\text { 1. Porque onde ela } \rightarrow \text { vegetação herbácea se localizava } \\
\text { foi se acabando e não tendo mais lugar para se } \\
\text { reproduzir, teve como necessidade de sobrevivência } \\
\text { "invadir" o local onde se situava a vegetação } \\
\text { arbustiva. Tudo isso devido ao aumento do nível do } \\
\text { mar, por isso o solo da vegetação arbustiva se tornou } \\
\text { apropriado para a reprodução da herbácea, assim, } \\
\text { tomando uma parte da vegetação arbustiva } \\
\text { (predomina) } \\
\text { 2. Esse processo foi feito pelo aumento do mar, que } \\
\text { possibilitou que a vegetação erbacia poderia se } \\
\text { reproduzir naquele devido local. A partir da elevaçãa } \\
\text { do nível do mar foi modificando o solo da vegetação } \\
\text { arbustiva e deixando esse solo apropriado para a } \\
\text { reprodução das vegetações herbácea. }\end{array}$ & Sem grifo \\
\hline 14 & $\begin{array}{l}\text { (2)... com o nível do mar subindo de poquim em poquim } \\
\text { tudo vai ser afetado destruindo a maioria da vegetação } \\
\text {... a vegetação vai ser completamente destruida por total. }\end{array}$ & $\begin{array}{l}\text { 1. eu acho que foi porque com a aproximação do mar a } \\
\text { areia foi ficando fina e a areia entrou dentro da } \\
\text { vegetação arbustiva e com isso a vegetação herbácea } \\
\text { entrou junto com a areia porque ela é rasteira e isso } \\
\text { ajudou a invadir a vegetação harbustiva e com isso a } \\
\text { herbácea fica mais densa } \\
\text { 2. O processo foi que a vegetação harbustiva ela é muito } \\
\text { alta e a vegetação herbácea ela age rasteiramente e } \\
\text { também com a ajuda da areia que entrou na } \\
\text { vegetação harbustiva e isso ajudou a herbácea entrar } \\
\text { porque ela é criada na areia e ela é rasteira e isso } \\
\text { facilitou entrar na vegetação harbustiva }\end{array}$ & $\begin{array}{l}\ldots \text { a vegetação herbácea } \\
\text { prodominava na faixa da } \\
\text { praia beirando a vegetação } \\
\text { arbustiva } \\
\ldots \text { A vegetação herbácea } \\
\text { possui raízes bastante } \\
\text { profundas e sistemas de } \\
\text { raízes e rizomas } \\
\ldots \text { vive nessa região é a } \\
\text { salsa-da-praia } \\
\ldots \text { protege contra a perda de } \\
\text { água } \\
\ldots \text { herbácea, as plantas } \\
\text { começam a ficar mais altas e } \\
\text { andar entre elas começa a } \\
\text { ficar difícil pois a vegetação } \\
\text { é muito mais densa. }\end{array}$ \\
\hline 15 & (2)... sim com o disperdicio dos humanos & 1. Porque a vegetação herbácea possui raízes bastante & A vegetação herbácea possui \\
\hline
\end{tabular}




\begin{tabular}{|c|c|c|c|}
\hline & ... não deixamos a vegetação afetar o mar & $\begin{array}{l}\text { profundas e sistemas de raízes e rizomas que fixam } \\
\text { as plantas na areia e as mantém mais estáveis, já que } \\
\text { a areia da praia se movimenta com muita facilidade } \\
\text { devido ao vento. } \\
\text { 2. Esse processo se deu com a aproximação do mar, e } \\
\text { então o mar ficou mais perto da vegetação. }\end{array}$ & $\begin{array}{l}\text { raízes bastante profundas e } \\
\text { sistemas de raízes e rizomas }\end{array}$ \\
\hline 16 & $\begin{array}{l}\text { (2)... com a elevação o mar cobre as vegetações. } \\
\text {... ela ira morrer, pois com a exageração de água ela pode } \\
\text { morrer. }\end{array}$ & $\begin{array}{l}\text { 1. Porque com a elevação do nível do mar, a areia } \\
\text { começou a afinar e com a força da água quebrou as } \\
\text { folhas das plantas fazendo que ela se reproduzi-se } \\
\text { rapidamente, entrando na outra vegetação. } \\
\text { 2. Com a reprodução rápida das plantas, que a força da } \\
\text { água quebrou com a elevação do nível do mar }\end{array}$ & Sem grifo \\
\hline 17 & $\begin{array}{l}\text { (2)... sua localização fica muito perto da água } \\
\text {... o homem pare de dar força ao aquecimento global pois } \\
\text { ele já sabe que isso pode afetar e muito a vegetação }\end{array}$ & $\begin{array}{l}\text { 1. Porque com a força da água que atinge a praia é } \\
\text { possível que uma abertura se forme que possibilita a } \\
\text { adentração da vegetação herbácea no território da } \\
\text { arbustiva e isso só ocorre graças as características da } \\
\text { vegetação arbustiva que faz com que ela não consiga } \\
\text { viver nas proximidades da água diferente da herbácea } \\
\text { que tem raízes profundas, rizoma e coroa que } \\
\text { possibilita a sobrevivência dela nesses locais. } \\
\text { 2. A vegetação herbácea pegou um tipo de "carona" na } \\
\text { água e com a força dessa água pressionada na praia } \\
\text { se foi possível adentração da vegetação herbácea no } \\
\text { território da vegetação arbustiva }\end{array}$ & $\begin{array}{l}\text { Esse tipo de planta é de } \\
\text { grande importância... } \\
\text { facilidade de regeneração } \\
\text { quando rompidas. }\end{array}$ \\
\hline 18 & $\begin{array}{l}\text { (2)... sim } \\
\ldots \text { não haverá mais vegetação }\end{array}$ & $\begin{array}{l}\text { 1. Ela estava somente em local no mar e com o passar } \\
\text { dos anos ela foi ocupando mais territórios porque ela } \\
\text { se adapto melho aquele ambiente } \\
\text { 2. Ela permite a invadir qualquer território para ela se } \\
\text { adaptar melhor }\end{array}$ & Sem grifo \\
\hline 19 & $\begin{array}{l}\text { (1)... a vegetação faz parte do meio ambiente e em } \\
\text { algumas partes não são poluídas e colaboram ( ) meio } \\
\text { ambiente } \\
\text {... a vegetação ao contrário da parte populosa, ira ser } \\
\text { preservada pois está de acordo com o meio ambiente } \\
\text { (2)... Em partes pois se ela foi poluída pode ser afetado }\end{array}$ & $\begin{array}{l}\text { 1. Porque a vegetação é menor e ela ficava beirando } \\
\text { mar, no entanto quando a faixa da aproximação do } \\
\text { mar ela consegue penetrar (invadir) o mar. } \\
\text { Concluindo a areia ficou bem mais fina do que antes } \\
\text { e o mar ficou mais prócimo, no entanto a vegetação } \\
\text { herbácea conseguiu invadir e tomar o lugar da }\end{array}$ & Sem grifo \\
\hline
\end{tabular}




\begin{tabular}{|c|c|c|c|}
\hline & $\begin{array}{l}\text { mas ao contrário não pode se afetado. } \\
\text {... ela será destruída com com a aproximação do mar. }\end{array}$ & $\begin{array}{l}\text { vegetação arbustiva. } \\
\text { 2. A vegetação herbácea é menor }(40 \mathrm{~cm}) \text { ao contrário } \\
\text { da vegetação arbustiva no entanto a vegetação } \\
\text { herbácea se espalha no chão e consegue fazer ocorrer } \\
\text { esse processo. A vegetação arbustiva não sobreveve } \\
\text { perto do mar e a herbácea sobreveve. Essa e uma das } \\
\text { características. }\end{array}$ & \\
\hline 20 & $\begin{array}{l}\text { (2)... A vegetação pode morrer com ecesso de água } \\
\text {... tomem uma previtensia para que os animais dessa } \\
\text { vegetação não morra }\end{array}$ & $\begin{array}{l}\text { 1. Por que a herbacia não tava tendo terra suficiente } \\
\text { para se manter viva por causa do mar } \\
\text { 2. Que a vegetação herbácea e muito pequena e a } \\
\text { arbustiva e muito grande então o herbacia conseguil } \\
\text { invadir }\end{array}$ & $\begin{array}{l}\ldots \text { herbácea... já que a areia } \\
\text { da praia se movimenta com } \\
\text { muita facilidades devido } \\
\ldots 20 \text { metros }\end{array}$ \\
\hline 21 & $\begin{array}{l}\text { (1)... não ( ) pode ser atingido } \\
\ldots \text { eles construa moradias para pessoas } \\
\text { (2)... sim porque o nível do mar sobe } \\
\ldots \text { sim eles não poderá construir moradias }\end{array}$ & $\begin{array}{l}\text { 1. Porque ele foi chegando perto do mar e ela invadio a } \\
\text { vegetação por a aproximação do mar ela foi } \\
\text { chegando a vegetação arbustiva } \\
\text { 2. Por a aproximação do mar }\end{array}$ & Sem grifo \\
\hline 22 & $\begin{array}{l}\text { (2)... com o aumento do nível do mar a restingua vai se } \\
\text { desgastando aos poucos. Ou seja uma fusão. } \\
\text {... ela vai se desgastando aos poucos }\end{array}$ & $\begin{array}{l}\text { 1. Porque o nível do mar aumentou e a característica da } \\
\text { vegetação herbacia é sobreviver á mais próximo da } \\
\text { praia, ou seja, perto da água do mar, já a vegetação } \\
\text { arbustiva não. } \\
\text { 2. A vegetação herbácia possui raízes bastante } \\
\text { profundas que fixam as plantas na areia e as mantém } \\
\text { estáveis, por isso ela é mais adapitada ao ambiente } \\
\text { próximo a água do mar, do que a arbustiva } \\
\text { Obs: Cada uma destas vegetações possuem características } \\
\text { diferentes que permitem que elas sobrevivem em } \\
\text { determinado local. }\end{array}$ & Sem grifo \\
\hline 23 & $\begin{array}{l}\text { (2)... com o aumento do nível do mar estragará a sua } \\
\text { vegetação } \\
\text {... vários animais iram morrer e arvores iram cair. }\end{array}$ & $\begin{array}{l}\text { 1. Porque a planta herbácea com o mar ela foi } \\
\text { expalhando pela vegetação arbustiva e a planta } \\
\text { arbustiva está morrendo por conta da água. } \\
\text { 2. Esse processo se deu a vegetação que começou a se } \\
\text { expandir através dos ventos e do mar com isso ela foi } \\
\text { se expalhando pela vegetação }\end{array}$ & Sem grifo \\
\hline 24 & $\begin{array}{l}\text { (1)... ela não vai ser destruída pelo mar } \\
\text {... ela não seja destruída pelo mar e que seja um local } \\
\text { limpo. }\end{array}$ & $\begin{array}{l}\text { 1. Características que mudam a medida que se } \\
\text { distanciam do mar. São influenciados principalmente } \\
\text { pelas condições do solo ( drenagem da água e }\end{array}$ & Sem grifo \\
\hline
\end{tabular}




\begin{tabular}{|c|c|c|c|}
\hline & & $\begin{array}{l}\text { disponibilidade de nutrientes. } \\
\text { Após a vegetação herbácea, as plantas começam a } \\
\text { ficar mais altas e andar, entre elas começa a ficar } \\
\text { difícil pois a vegetação é muito mais densa: é a } \\
\text { vegetação arbustiva, que pode chegar a } 3 \text { metros de } \\
\text { altura. }\end{array}$ & \\
\hline 25 & $\begin{array}{l}\text { (2)... os níveis do mar esta alto afogando vegetaes } \\
\text {... o nível do mar abaixa um pouco }\end{array}$ & $\begin{array}{l}\text { 1. porque, com o nível do mar foi encostando vegetação } \\
\text { herbácea ela foi crecendo ate chegar na vegetação } \\
\text { arbustiva e se distanciando e se afastando perto dos } \\
\text { vegetais arbustiva } \\
\text { 2. se deu com o nível da água encostando nos vegetais e } \\
\text { os vegetais foram se distanciando do mar até chegar } \\
\text { nas vegetaçaões arbustivas. }\end{array}$ & Sem grifo \\
\hline 26 & $\begin{array}{l}\text { (2)... com o aumento do mar o mar vai tramportar } \\
\ldots \text { vai ser modificado e plantas iram morrer, com a } \\
\text { enchente }\end{array}$ & $\begin{array}{l}\text { 1. porque foi crescendo com o aumento do mar e elas se } \\
\text { distamciam e tomam o lugar da vegetação arbustiva } \\
\text { 2. com o aumento do nível do mar, ela foi se } \\
\text { distanciando }\end{array}$ & $\begin{array}{l}\text { diferentes características que } \\
\text { mudam à medida que se } \\
\text { distanciam do mar }\end{array}$ \\
\hline
\end{tabular}


